\title{
Avaliação da reação do tecido subcutâneo de ratos à implantação dos cimentos MTA e Portland brancos acrescidos de radiopacificadores
}

EDUARDO ANTUNES BORTOLUZZI

Dissertação apresentada à Faculdade de Odontologia de Bauru da Universidade de São Paulo, como parte dos requisitos para obtenção do título de Mestre em Odontologia, área de Endodontia.

(Edição Revisada)

Bauru 


\section{Avaliação da reação do tecido subcutâneo de ratos à implantação dos cimentos MTA e Portland brancos acrescidos de radiopacificadores}

\section{EDUARDO ANTUNES BORTOLUZZI}

Dissertação apresentada à Faculdade de Odontologia de Bauru da Universidade de São Paulo, como parte dos requisitos para obtenção do título de Mestre em Odontologia, área de Endodontia.

(Edição Revisada)

Orientador: Prof. Dr. Clovis Monteiro Bramante

Bauru

2005 

dos cimentos MTA e Portland brancos acrescidos de radiopacificadores / Eduardo Antunes Bortoluzzi - Bauru, 2005. xxiv, 175p. : il. ; $30 \mathrm{~cm}$.

Dissertação (Mestrado) - Faculdade de Odontologia de Bauru. Universidade de São Paulo.

Orientador: Prof. Dr. Clovis Monteiro Bramante

Data de aprovação pelo comitê de Ética em pesquisa da Faculdade de Odontologia de Bauru-USP: 5 de Novembro de 2003.

A cópia do parecer de aprovação encontra-se no capítulo "Apêndice".

Autorizo, exclusivamente para fins acadêmicos e científicos, a reprodução total ou parcial desta dissertação, por processos fotocopiadores e outros meios eletrônicos.

Assinatura: 


\section{Universidade de São Paulo \\ Faculdade de Odontologia de Bauru}

AI. Dr. Octávio Pinheiro Brisolla, 9-75 - Bauru-SP - CEP 17012-901 - C.P. 73 PABX (0XX14)235-8000 - FAX (0XX14)223-4679

\section{Pós-Graduação}

e-mail: posgrad@fob.usp.br -Fone: (0XX14)235-8223

\section{FOLHA DE APROVAÇ̃̃O}

Dissertação apresentada e defendida por EDUARDO ANTUNES BORTOLUZZI

e aprovada pela Comissão Julgadora em 15 de fevereiro de 2005 .

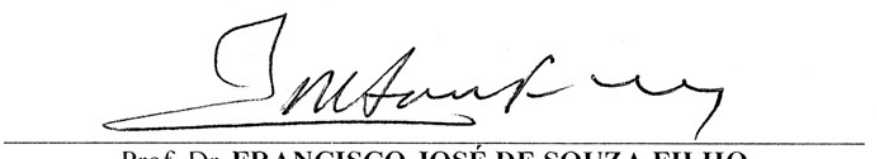

Prof. Dr. FRANCISCO JOSÉ DE SOUZA FILHO

Faculdade de Odontologia de Piracicaba - UNICAMP

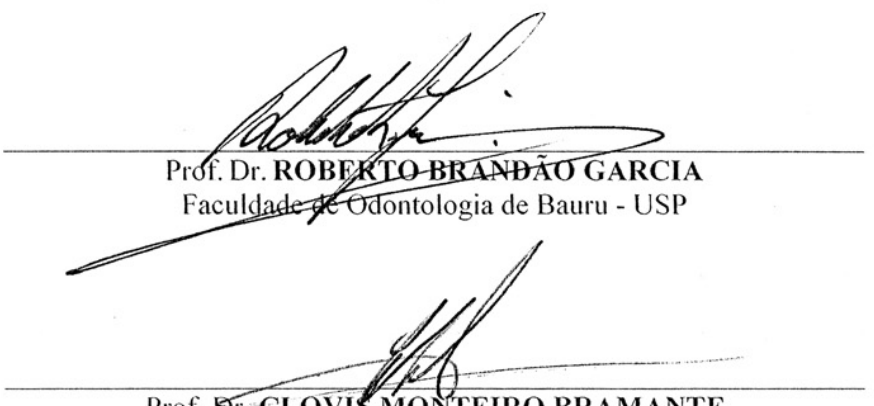

Prof OL CLOVIS MONTEIRO BRAMANTE

Presidente da Banca

Faculdade de Odontologia de Bauru - USP

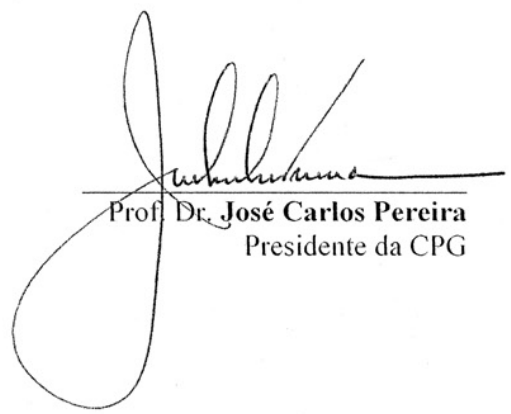




\section{Eduardo Antunes Bortoluzzi}

05 de Agosto de 1973

Filiação

$1993-1998$

$1999-2000$

$1999-2001$

$2002-2003$

$2003-2005$

Associações
Nascimento em Tubarão, Santa Catarina, Brasil.

Adalberto Ghizzo Bortoluzzi e

Dalcy Antunes Bortoluzzi

Curso de Graduação em Odontologia na Faculdade de Odontologia da Universidade Federal de Santa Catarina

Curso de Especialização em Endodontia na Universidade Federal de Santa Catarina

Professor Substituto da Disciplina de Endodontia da Universidade Federal de Santa Catarina

Professor Voluntário da Disciplina de Endodontia da Universidade Federal de Santa Catarina

Curso de Pós-Graduação em nível de Mestrado em Odontologia, Área de concentração em Endodontia, na Faculdade de Odontologia de Bauru, Universidade de São Paulo

ABO - Associação Brasileira de Odontologia - SC.

ACE - Associação Catarinense de Endodontia.

SBPqO - Sociedade Brasileira de Pesquisa

Odontológica, Brasil. 


\title{
DEDICATÓRIA
}

\section{A minha querida mãe, Dalcy (com saudades)}

\author{
"Minha estrela guia, \\ minha força maior, \\ minha lágrima e meu riso, \\ meu grande aprendizado, \\ minha maior saudade! \\ voou \\ como um pássaro... \\ voou, \\ virou estrela... \\ a mais linda estrela do meu céu!"
}

Mariú Zalaf

\section{A meu pai, Adalberto,}

Paizão! Tudo que sou devo a você, que sempre acreditou em mim, até nos momentos em que eu mesmo não acreditava, você estava lá, me passando confiança e com tanta convicção faz̧ia eu seguir em frente. Amo-te muito, você é energia, meu incentivo constante, conselheiro de todas as horas, é pai, e agora também mãe. Hoje você colbe um pouco do que tanto lutou para dar a seus filhos, nunca vou esquecer disso, guardarei como exemplo para os meus. 
Pegue um sorriso e doe-o a quem jamais o teve.

Pegue um raio de sol

e faça-o voar lá onde reina a noite.

Descubra uma fonte

e faça banhar-se quem vive no lodo.

Pegue uma lágrima

e ponha-a no rosto de quem jamais chorou.

Pegue a coragem

e ponha-a no ânimo de quem não sabe lutar.

Descubra a vida

e narre-a a quem não sabe entendê-la.

Pegue a esperança

e viva na sua luz.

Pegue a bondade

e doe-a a quem não sabe doar.

Descubra o amor

e faça-o conhecer o mundo. 


\section{MEU AGRADECIMENTO ESPECIAL}

Ao meu orientador,

\section{Prof. Dr. Clovis Monteiro Bramante,}

Pelo exemplo de competência, paciência, conhecimento e determinação. Pela preciosa orientação, ensinamentos recebidos, pela confiança em mim depositada. Pela dedicação, apoio, convivência, amizade e incentivo constante que foram fundamentais para realização deste trabalho e contribuíram muito para o meu desenvolvimento $e$ crescimento profissional e pessoal.

Meu sincero respeito e gratidão

"Educar é ensinar a pensar sozinho." 
Pela oportunidade de desenvolver meu trabalho na Patologia Bucal da FOBUSP, onde adquiri conhecimento técnico e cientifico. Pelas orientações valiosas que contribuiram significantemente com o trabalho. Pelo exemplo de profissionalismo, conhecimento e dedicação. Pela confiança em mim depositada, pela amiz̧ade que muito me honra, e pelo privilégio dessa convivência, que contribui de modo especial para minha formação

Meu reconhecimento e gratidão

\author{
"Uma nuvem não sabe \\ porque se move em tal \\ direção e em tal velocidade,
}

Sente o impulso... é para

Este lugar que devo ir agora. Mas o céu sabe

os motivos e desenhos

por trás de todas as nuvens,

e você também saberá, quando

se erguer o suficiente

para ver além dos

horizontes."

Richard Bach 


\title{
Ao Prof. Dr. Wilson Tadeu Felippe
}

Pelo inicio de tudo, por ter despertado em mim o amor pela Endodontia e pelo ensino. Você plantou uma sementinha, e que agora esta gerando frutos, muito obrigado por todas as oportunidades, todos ensinamentos, confiança e amizade. O seu eterno aluno, carinhosamente chamado de "aspirante", lhe agradece muito, pois você o ajudou a encontrar o rumo a ser seguido.

Minha admiração e reconbecimento

\footnotetext{
"Vivemos com o que recebemos, mas marcamos a vida com o que damos."
}

\author{
Winston Churchill
}




\section{MEU AGRADECIMENTO ESPECIAL}

\section{À Deus}

Por guiar meus passos, por jamais ter me deixado só, por iluminar meu caminho e por provar, a cada dia, das mais variadas formas, que Seu amor é infinito, e que, portanto, vale a pena sonbar...

...V ale a pena acreditar.

Aos meus pais,

Pelo imenso amor, carinho, compreensão, Pelo apoio sempre presente em todos os momentos de minha vida, acreditando e confiando em mim, Pelo constante incentivo, não permitindo que eu me entregasse frente aos desafios, nem me deixasse vencer pelas dificuldades,

Pelo valioso auxilio na luta pelos meus objetivos,

Por todos os ensinamentos, orientaçoes...

...palavras não são suficientes para expressar o amor e a admiração que sinto por vocês!! 


\section{À meus irmãos Beatriz e Henrique,}

Mesmo à distância, sentia vocês ao meu lado, em alma e coração, acompanbando meus passos, me incentivando a seguir em frente. Amo muito vocês!

\section{À Cristina,}

Pessoa muito especial em minha vida. Agradeço pelo apoio, compreensão, paciência, amor e carinho em todos os momentos, e por continuar ao meu lado, nesta caminhada. 


\section{AGRADECIMENTOS}

À Faculdade de Odontologia de Bauru da Universidade de São Paulo, através da sua atual diretora, Prof ${ }^{a}$. Dr ${ }^{a}$. Maria Fidela de Lima Navarro e à Comissão de Pós-Graduação, na pessoa de seu atual presidente, Prof. Dr. José Carlos Pereira, pelo apoio à pesquisa.

Aos Professores da disciplina de Endodontia da FOB-USP, Clovis Monteiro Bramante, Alceu Berbert, Ivaldo Gomes de Moraes, Norberti Bernadinelli e Roberto Brandão Garcia, pelos ensinamentos, orientações nas aulas e nas pesquisas, e pela amizade.

Aos Professores da disciplina de Endodontia da UFSC, Ana Maria Hecke Alves, Beatriz D. Souza Mendes, Cleonice da Silveira Teixeira, Luciano Rodrigues Veiga, Mara Cristina Santos Felippe, Maria Helena Pozzobon, Nelson Luiz da Silveira, Patrícia Regina Vigano, Wilson Tadeu Felippe, e aos funcionários do Laboratório de Pesquisas em Endodontia-UFSC, Jacqueline Caldeira de Andrada Natividade, Márcio Tavares, Marly Nunes e Sérgio Batista Andrade, pela amizade, convivência, apoio e incentivo. Esta conquista é nossa.

Aos professores da disciplina de Patologia Bucal da Faculdade de Odontologia de Bauru, Profs. Drs. Alberto Consolaro, Luis Antônio de Assis Taveira, Denise Tostes Oliveira e Vanessa Soares Lara, pelo convívio amistoso, ensinamentos e incentivo.

À todos os professores do curso de Pós-Graduação da FOB-USP, que contribuíram para a minha formação.

Aos Professores Doutores Ilson José Soares, Luiz Narciso Baratieri e Maria José de Carvalho Rocha, pela confiança depositada em mim nas cartas de apresentação.

Aos Doutores Ernesto García Yañez e Alejandro Bates Souza, da empresa Dentsply - México, México D.F. e Doutores Roberto Quiroz Martins Alcântara e Lygia Madi Kranz, da empresa Angelus - Soluções Odontológicas - Londrina PR, Brasil, pela amizade e contribuição com material para o desenvolvimento desta pesquisa.

Ao CNPq, pelo suporte financeiro. 
Ao pessoal da Disciplina de Histologia, as biólogas Tânia Mary Cestari e Daniele Santi Ceolin, sempre dispostas a ajudar com o maior desprendimento, obrigado pelos conselhos e ensinamentos para realização deste trabalho.

Ao Prof. Dr. José Roberto Pereira Lauris, da disciplina de Saúde Coletiva da Faculdade de Odontologia de Bauru, pelo tempo, orientações e ajuda na análise estatística.

Ao Prof. Dr. Marco Antônio Húngaro Duarte (Sal), da disciplina de Endodontia da Faculdade de Odontologia da Universidade do Sagrado Coração, pela amizade e grande contribuição nos trabalhos experimentais, das propriedades físico-químicas, dos materiais utilizados nesta pesquisa.

Ao amigo Norberto Juarez Broon, pela ajuda nos procedimentos clínicos com os animais, nos testes de laboratório, publicações e nos trabalhos de pesquisa realizados juntos.

Aos colegas do curso de Mestrado, da FOB-USP, Thais Accorsi Mendonça, Danieli Colaço Ribeiro Siqueira, Adriana Lustosa Pereira, Luciano Tavares Ângelo Cintra, Augusto Bodanezi, Amélio Borges Taveira, Jarcio Victorio Baldi e Norberto Juarez Broon, pelos bons momentos de convivência nas aulas, clínica e laboratório e pelo constante aprendizado. Que todos consigamos atingir os objetivos pelos quais lutamos.

Aos funcionários da Disciplina de Endodontia da FOB-USP, Suely Regina Bettio, Neide Leandro, Patrícia Fernanda Vital Lopes e Edimauro de Andrade, meu muito obrigado por todo auxílio e pelo carinho.

À amiga Fernanda Gomes de Moraes, pela amizade e contribuição nos procedimentos laboratoriais.

Ao amigo, Tiago Novaes Pinheiro, pela grande ajuda e ensinamentos na análise microscópica.

À Marta Miyazawa, pela disponibilidade e realização das fotos deste trabalho.

Ao Miguelito, pela amizade, conselhos e incentivo constante. 
Ao Felipe, amigo verdadeiro de longa data. Eterno companheiro de todas as horas.

Aos colegas de pós-graduação do Doutorado e Mestrado em Patologia Bucal: João Adolfo, Aline, Maria Renata, Rosário, Marta, Patrícia, Suzana, Leda, Erick, Maria Fernanda, Renata Consolaro, Renata Falchete, Luciana, Renato, Bethânia, Tiago, Lidiane, Camila, por todas horas de convivência, sempre prazerosas e alegres.

Aos funcionários da Patologia: Sr. Valdir João Afonso, amigo que me deu muita força até nos últimos momentos. À Fátima Aparecida Silveira (Fatiminha), encontrei uma grande amiga, agradeço pelos conselhos, pelos momentos que foste mãe, reconhecendo a dor sem que houvesse sido manifestada, a aflição sem que fosse reclamada, oferecendo, nos pequenos gestos, a atenção que nunca será esquecida. À Maria Cristina Carrara Felipe, sempre atendendo minhas solicitações com o mais puro desprendimento, ajuda e carinho. Ao Oziel, pela nova amizade. Vocês foram muito acolhedores e especiais.

Aos funcionários do Biotério da FOB-USP, Luiz Carlos da Silva, Erasmo Gonçalves da Silva, Richard Nelson Guanaes Simões e Wagner Jitulo Nita, pela disponibilidade, ajuda, total atenção durante os procedimentos laboratoriais e cuidados com os animais utilizados neste trabalho.

Ao pessoal da Disciplina de Bioquímica da FOB-USP, Prof. Dr. José Mauro Granjeiro e os funcionários Thelma Lopes Silva e Ovídio dos Santos Sobrinho, pela oportunidade de trabalhar no laboratório e o auxílio nos testes efetuados com os materiais utilizados nesta pesquisa.

A todos os funcionários da Biblioteca e Documentação "Prof. Dr. Antônio Gabriel Atta", da FOB-USP, na pessoa de sua atual chefe, Cybelle de Assumpção Fontes e em especial às bibliotecárias Valéria Cristina Trindade Ferraz, Rita de Cássia Paglione, Vera Regina Casari Boccato e o Ademir Padilha, pela ajuda em todo momento, bem como aos funcionários da Reprografia, especialmente o Salvador, pela constante colaboração e amizade.

Aos colegas da Pós-Graduação de todas as áreas e aos alunos da Graduação, pelo convívio e aprendizado.

Aos animais utilizados neste trabalho, por darem suas vidas em benefício da espécie humana e contribuírem para a ciência endodôntica. 


\section{SUMÁRIO}

pág.

LISTA DE FIGURAS

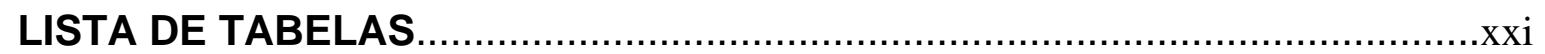

LISTA DE ABREVIATURAS, SIGLAS E SÍMBOLOS ...................................xii

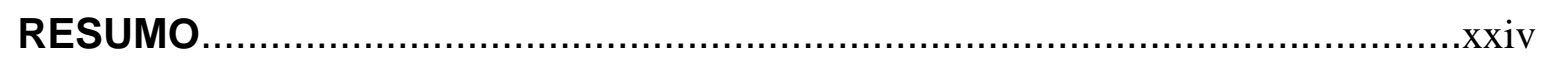

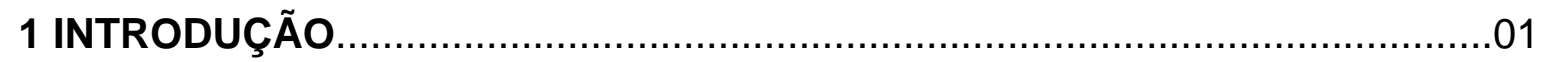

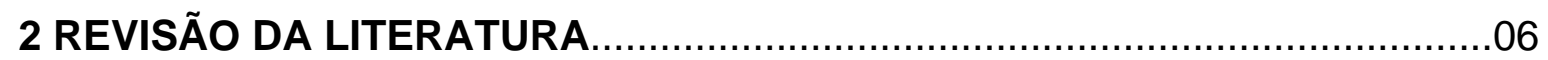

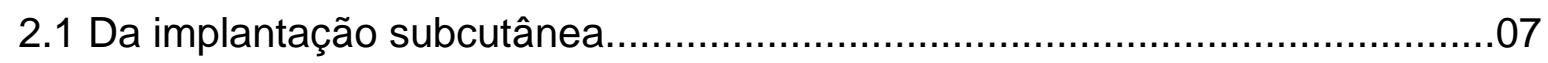

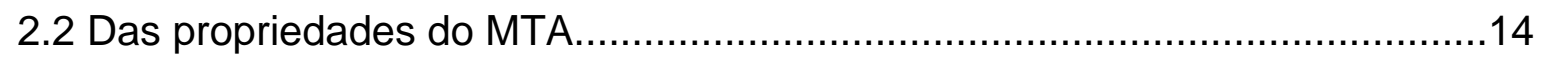

2.3 Da comparação do MTA com o cimento Portland.........................................45

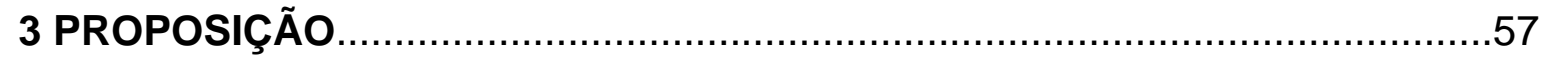

4 MATERIAL E MÉTODOS

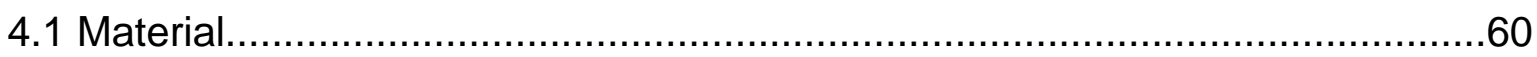

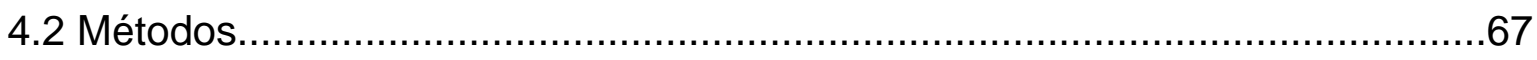

5 RESULTADOS

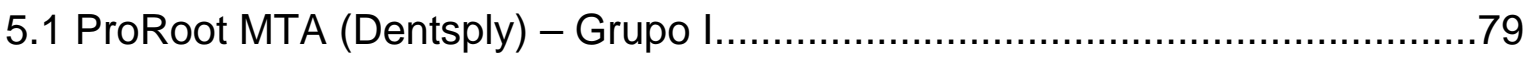

5.1.1 Análise microscópica descritiva do infiltrado inflamatório dos fenômenos reparatórios e reações correlatas no período de 15 dias.....................................79

5.1.2 Análise microscópica descritiva do infiltrado inflamatório dos fenômenos reparatórios e reações correlatas no período de 30 dias.

5.1.3 Análise microscópica descritiva do infiltrado inflamatório dos fenômenos reparatórios e reações correlatas no período de 60 dias. 81

5.2 MTA Branco com sulfato de bário - Grupo II.

5.2.1 Análise microscópica descritiva do infiltrado inflamatório dos fenômenos reparatórios e reações correlatas no período de 15 dias. .84

5.2.2 Análise microscópica descritiva do infiltrado inflamatório dos fenômenos reparatórios e reações correlatas no período de 30 dias. .85 
5.2.3 Análise microscópica descritiva do infiltrado inflamatório, dos fenômenos reparatórios e reações correlatas no período de 60 dias. .86 5.3 MTA Branco com óxido de bismuto - Grupo III. .89

5.3.1 Análise microscópica descritiva do infiltrado inflamatório dos fenômenos reparatórios e reações correlatas no período de 15 dias.

5.3.2 Análise microscópica descritiva do infiltrado inflamatório dos fenômenos reparatórios e reações correlatas no período de 30 dias. 90

5.3.3 Análise microscópica descritiva do infiltrado inflamatório dos fenômenos reparatórios e reações correlatas no período de 60 dias. 91

5.4 Cimento Portland branco (Irajazinho) - Grupo IV.

5.4.1 Análise microscópica descritiva do infiltrado inflamatório dos fenômenos reparatórios e reações correlatas no período de 15 dias.

5.4.2 Análise microscópica descritiva do infiltrado inflamatório dos fenômenos reparatórios e reações correlatas no período de 30 dias. .95

5.4.3 Análise microscópica descritiva do infiltrado inflamatório dos fenômenos reparatórios e reações correlatas no período de 60 dias. .96 5.5 Guta-percha (Controle) - Grupo V.

5.5.1 Análise microscópica descritiva do infiltrado inflamatório dos fenômenos reparatórios e reações correlatas nos períodos de 15, 30 e 60 dias 99 5.6 Análise estatística da intensidade inflamatória, proliferação fibroblástica, proliferação angioblástica e densidade do fibrosamento, caracterizados por escores, nos três períodos experimentais. 101

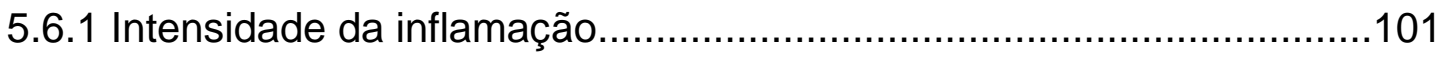

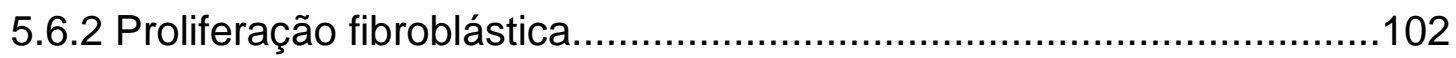

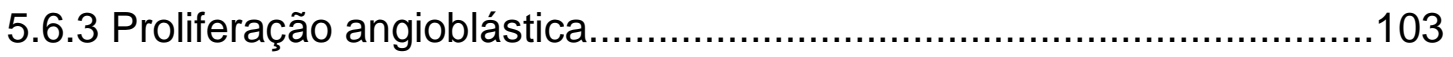

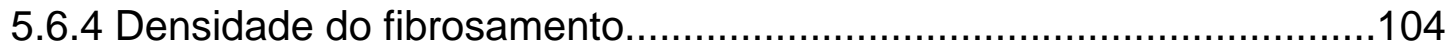

6 DISCUSSÃO

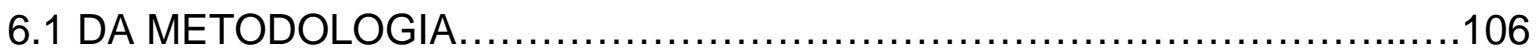

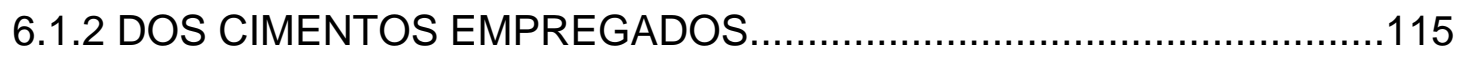

6.1.2.1 A escolha do ProRoot MTA e MTA-Angelus............................115

6.1.2.2 A escolha do Cimento Portland branco não estrutural...............118

6.1.2.3 A escolha da guta-percha como controle...............................120 


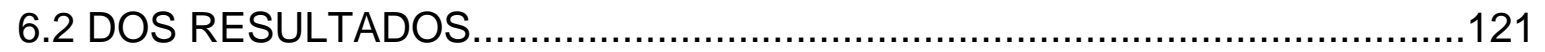

6.2.1 Reação tecidual frente aos materiais implantados........................121

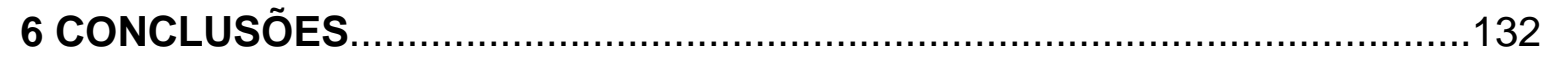

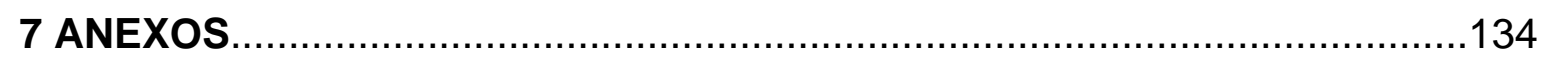

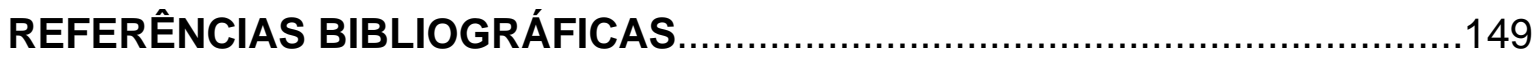

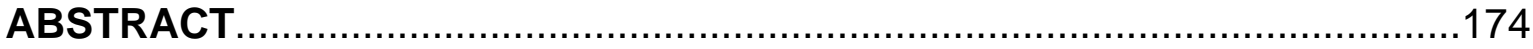

APÊNDICES 


\section{LISTA DE FIGURAS}

Figura 1

Figura 2

Figura 3

Figura 4

Figura 5

Figura 6

Figura 7

Figura 8

Figura 9

Figura 10

Figura 11

Figura 12

Figura 12

Figura 13A

Figura 13B

Figura 13C

ProRoot MTA, embalagem contendo 5 envelopes com 1 grama de 66 pó cada e recipientes plásticos com água destilada esterilizada.

Amostras para ensaio do MTA Branco, uma contendo óxido de 66 bismuto e a outra sulfato de bário.

Embalagem de $1 \mathrm{Kg}$ do cimento Portland branco.

Tubos de polietileno fechados por guta-percha em uma das 68 extremidades.

Trocarte: instrumento que foi utilizado para conduzir os tubos de 68 polietileno. O lado do tubo com cimento ficou voltado para área do tecido menos traumatizada pelo ato cirúrgico (maior aumento).

Trocarte introduzido entre o tecido cutâneo e o tecido muscular, 68 onde foi depositado o tubo de polietileno preenchido com o cimento.

Localização das incisões e distribuição dos tubos de polietileno 68 implantados no dorso dos animais.

Biópsia do tecido circunjacente aos tubos de polietileno. 71

Peça após o corte macroscópico. $\quad 71$

Apreensão do tubo com a pinça clínica e incisão lateral e 71 longitudinal do tecido sobre o tubo para a sua remoção.

Remoção do tubo após descolamento do tecido. Neste momento o 71 lado controle foi identificado, para posterior marcação.

Peça sem o tubo de polietileno após passagem pelo histotécnico. 71

A cápsula foi aberta para ser mergulhada novamente na parafina líquida.

Reação tecidual aos 15 dias, caracterizada por um tecido 83 neoformado (H.E.- 5x).

Maior aumento da figura 13A, onde se observa grande 83 proliferação fibroblástica e partículas do material nos macrófagos (H.E.- 40x).

Reação tecidual aos 30 dias, assumindo o aspecto de 83 fibrosamento. (H.E.- 5x). 
Figura 13D Maior aumento da figura 13C, onde se observa as fibras 83 colágenas mais organizadas com fibroblastos com aspecto de menor atividade (H.E.- 40x).

Figura 13E Reação tecidual aos 60 dias, destaca-se a organização da cápsula fibrosa (H.E.- 5x).

Figura 13F Maior aumento da figura 13E, evidenciando o infiltrado inflamatório ainda existente, composto por macrófagos e linfócitos. Presença de neoformação angioblástica (H.E.- 40x).

Figuras 13G, Visão geral do tecido conjuntivo adjacente a guta-percha 83 $13 \mathrm{I}$ e $13 \mathrm{~K}$ (controle) na abertura do tubo, nos períodos de 15, 30 e 60 dias, respectivamente (H.E.- 5x).

Figuras $13 \mathrm{H}$, Maiores aumentos das figuras 13G, 13I e 13K. Em H destaca-se 83 $13 \mathrm{~J}$ e $13 \mathrm{~L}$ uma CGMI com muitos núcleos. Nas figuras 13J e 13L, nota-se o aumento da densidade de fibrosamento e discreto infiltrado inflamatório (H.E.- 40x).

Figura 14A Reação tecidual aos 15 dias, destaca-se a fina cápsula fibrosa 88 (H.E.-5x).

Figura 14B Maior aumento da figura 14A, evidenciando partículas de 88 coloração escura do material e macrófagos tentando fagocitá-las. Presença de grande proliferação angioblástica (H.E.- 40x).

Figura 14C Reação tecidual aos 30 dias, destaca-se pelo aumento da cápsula 88 fibrosa (H.E.- 5x).

Figura 14D Maior aumento da figura 14C, presença acentuada de células 88 mononucleares e hemorragia (H.E.- 40x).

Figura 14E Reação tecidual aos 60 dias, destaca-se a grau de fibrosamento, 88 com a invaginação do tecido neoformado para dentro do tubo (H.E.-5x).

Figura 14F Maior aumento da figura 14E, evidenciando o tecido conjuntivo 88 denso permeado por fibroblastos e acúmulo células na extremidade do tecido (H.E.- 40x).

Figuras 14G, Visão geral do tecido conjuntivo adjacente a guta-percha 88 $14 \mathrm{I}$ e 14K (controle) na abertura do tubo, aos 15, 30 e 60 dias, respectivamente (H.E.-5x). 
Figuras 14H, Maiores aumentos das figuras 14G, 14I e 14K. Em H encontram- 88

$14 \mathrm{~J}$ e $14 \mathrm{~L} \quad$ se partículas dentro do tecido. Nas figuras $14 \mathrm{~J}$ e $14 \mathrm{~L}$, nota-se 0 aumento da densidade de fibrosamento e em $\mathrm{L}$ o infiltrado inflamatório esta praticamente ausente (H.E.- 40x).

Figura 15A Reações teciduais aos 15 dias, evidenciando cápsula fibrosa já 93 organizada (H.E.- 5x).

Figura 15B Maior aumento da figura 15A, onde se vê a disposição dos feixes de fibras colágena com poucos fibroblastos (H.E.- 40x).

Figura 15C Reação tecidual aos 30 dias, destaca-se pelo aumento da cápsula 93 fibrosa (H.E.- 5x).

Figura 15D Maior aumento da figura 15C, presença acentuada de células 93 mononucleares. Presença de CGMI e área de necrose superficial do tecido (H.E.- 40x).

Figura 15E Reação tecidual aos 60 dias frente o material implantado (H.E.- 93 $5 x)$.

Figura 15F Maior aumento da figura 15E, evidenciando o tecido conjuntivo 93 denso permeado por fibroblastos, e com partículas do material no interior de macrófagos (H.E.- 40x).

Figuras 15G, Visão geral do tecido conjuntivo adjacente a guta-percha 93 15I e 15K (controle) na abertura do tubo, aos 15, 30 e 60 dias, respectivamente (H.E.- 5x).

Figuras $15 \mathrm{H}$, Maiores aumentos das figuras $15 \mathrm{G}, 15 \mathrm{I}$ e $15 \mathrm{~K}$. Em H é visto abaixo da cápsula fibrosa um intenso infiltrado inflamatório. Em J e $\mathrm{L}$, nota-se o aumento da densidade de fibrosamento, com menos fibroblastos entre as fibras no período de 60 e praticamente ausência de inflamação (H.E.- 40x).

Figura 16A Reações teciduais aos 15 dias, evidenciando cápsula fibrosa 98 muito fina (H.E.- $5 x)$.

Figura 16B Maior aumento da figura 16A, onde se vê grande hemorragia, 98 fibroblastos envoltos por poucas fibras colágenas e partículas escuras do material cercada por macrófagos. Destacam-se cristais com forma poligonal e aparência hialina (setas), circundados por células inflamatórias (H.E.- 40x).

Figura 16C Reação tecidual aos 30 dias, destaca-se pelo aumento da cápsula 98 fibrosa (H.E.- 5x). 
Figura 16D Maior aumento da figura 16C, presença acentuada de células 98 mononucleares. Presença fragmentos do material nos macrófagos (H.E.- 40x).

Figura 16E Reação tecidual aos 60 dias frente o material implantado (H.E.- 98 $5 x)$.

Figura 16F Maior aumento da figura 16E, evidenciando o tecido conjuntivo 98 denso com muitos fibroblastos, e com cristais provavelmente do material no seu interior (H.E.- 40x).

Figuras 16G, Visão geral do tecido conjuntivo adjacente a guta-percha 98 16I e 16K (controle) na abertura do tubo, aos 15, 30 e 60 dias, respectivamente (H.E.- 5x).

Figuras 16H, Maiores aumentos das figuras 16G, 16I e 16K. Em H observa-se 98 16J e 16L grande quantidade do material na interface. Na figura 16I destacase a grande proliferação fibroblástica, já na $16 \mathrm{~L}$ diminuição do número de célula e grande aumento da densidade do fibrosamento, com praticamente ausência de inflamação (H.E.40x).

Figura 17 Montagem: tubo de polietileno e tecido subcutâneo de rato 105 representando o canal radicular e ligamento periodontal. 


\section{LISTA DE TABELAS}

pág.

Tabela 1 Distribuição dos implantes em relação aos materiais e períodos 65 empregados no experimento.

Tabela 2 Critérios de classificação dos níveis de concordância de 75 coeficiente Kappa.

Tabela 3 Coeficiente de concordância (Kappa) para os fenômenos 76 inflamatório e reparatório nos três períodos analisados.

Tabela 4 Médias dos escores da intensidade inflamatória dos grupos nos 101 três períodos experimentais; comparação entre os grupos em cada período e comparação de cada material em relação ao tempo.

Tabela 5 Médias dos escores da proliferação fibroblástica dos grupos 102 nos três períodos experimentais; comparação entre os grupos em cada período e comparação de cada material em relação ao tempo.

Tabela 6 Médias dos escores da proliferação angioblástica dos grupos 103 nos três períodos experimentais, comparação entre os grupos em cada período e comparação de cada material em relação ao tempo.

Tabela 7 Médias dos escores da densidade do fibrosamento dos grupos nos três períodos experimentais, comparação entre os grupos em cada período e comparação de cada material em relação ao tempo. 


\section{LISTA DE ABREVIATURAS, SIGLAS E SÍMBOLOS}

\begin{tabular}{|c|c|}
\hline $\mathrm{m}$ & - Metros \\
\hline $\mathrm{cm}$ & - Centímetro \\
\hline $\mathrm{mm}$ & - Milímetro \\
\hline $\mathrm{ml}$ & - Mililitro \\
\hline$\mu \mathrm{m}$ & - Micrometro \\
\hline $\mathrm{Kg}$ & - Kilograma \\
\hline $\mathrm{mg}$ & - Miligrama \\
\hline g & - Grama \\
\hline $\mathrm{ml}$ & - Mililitro \\
\hline $\mathrm{ml} / \mathrm{kg}$ & - Mililitro por kilograma \\
\hline $\mathrm{mg} / \mathrm{kg}$ & - Miligrama por kilograma \\
\hline $\mathrm{mg} / \mathrm{lt}$ & - Miligrama por litro \\
\hline h & - Hora(s) \\
\hline $\min$ & - Minutos \\
\hline seg & - Segundo(s) \\
\hline$n^{0}$ & - Número \\
\hline PMNs & - Polimorfonucleares neutrófilos \\
\hline CGMIs & - Células gigantes multinucleadas \\
\hline PVPI & - Polivinilpirrolidona iodo \\
\hline $\mathrm{Ca}(\mathrm{OH})_{2}$ & - Hidróxido de cálcio \\
\hline $\mathrm{NaOCl}$ & - Hipoclorito de sódio \\
\hline ISO & - International Organization for Standardisation \\
\hline ADA & - American Dental Association \\
\hline FDI & - Fédération Dentaire Internationale \\
\hline UI & - Unidades Internacionais \\
\hline$\%$ & - Porcentagem \\
\hline \pm & -Mais ou menos \\
\hline X & -Vezes \\
\hline
\end{tabular}




\begin{tabular}{|c|c|}
\hline$=$ & - igual \\
\hline${ }^{\circ} \mathrm{C}$ & - Graus Celsius \\
\hline $\mathrm{pH}$ & - Potencial hidrogeniônico \\
\hline ppm & - Partes por milhão \\
\hline $\mathrm{Hg}$ & - Mercúrio \\
\hline H.E. & - Hematoxilina e Eosina \\
\hline$p$ & - Nível de significância \\
\hline MEV & - Microscopia eletrônica de varredura \\
\hline MTA & - Agregado trióxido mineral \\
\hline IRM & - Material Restaurador Intermediário \\
\hline EBA & - Ácido etoxybenzóico \\
\hline EDTA & - Ácido etileno diaminotretacético \\
\hline CIV & - Cimento de ionômero de vidro \\
\hline Ltda. & - Limitada \\
\hline EUA & - Estados Unidos da América \\
\hline ADA & - Associação Dental Americana \\
\hline ISO & - International Organization for Standardization \\
\hline CEEPA & $\begin{array}{l}\text { - Comissão de Ética no Ensino e Pesquisa em } \\
\text { Animais }\end{array}$ \\
\hline FOB & - Faculdade de Odontologia de Bauru \\
\hline USP & - Universidade de São Paulo \\
\hline USC & -Universidade do Sagrado Coração \\
\hline
\end{tabular}




\section{RESUMO}

O MTA por apresentar boas propriedades físico-químicas e biológicas é indicado como material retrobturador. O objetivo deste trabalho foi avaliar, microscopicamente, a resposta do tecido subcutâneo de ratos frente à implantação de tubos de polietileno contendo novas formulações desse material: ProRoot MTA $^{\circledR}$, MTA Branco ${ }^{\circledR}$ contendo dois tipos de radiopacificadores e cimento Portland branco com óxido de bismuto. Foram utilizados 36 ratos (Rattus norvegicus), divididos em 12 animais para cada período experimental. Cada animal recebeu quatro implantes de tubos de polietileno, preenchidos com os materiais recém-espatulados de um lado, e do outro guta-percha (controle). Após 15, 30 e 60 dias os animais foram mortos e os espécimes foram preparados para análise microscópica. Os resultados mostraram inflamação crônica granulomatosa induzida pelos materiais, com intensidade moderada a discreta, e organização e espessamento de uma cápsula fibrosa com o passar do tempo. Os cimentos induziram respostas teciduais semelhantes, mesmo com radiopacificadores diferentes na composição. 


\section{INTRODUÇÃO}




\section{INTRODUÇÃO}

O Agregado de Trióxido Mineral (MTA) foi inicialmente desenvolvido para ser empregado em cirurgias periapicais como material retrobturador e para selar as comunicações entre o sistema de canal(is) radicular(es) e o periodonto (TORABINEJAD; WATSON; PITT FORD ${ }^{157}$, 1993; TORABINEJAD et al. ${ }^{158}$, 1994; TORABINEJAD et al. ${ }^{159,163}, 1995$; TORABINEJAD et al. ${ }^{165}$, 1997; PITT FORD et al. $\left.{ }^{122}, 1995\right)$.

O MTA é um pó que possui como principais componentes o silicato tricálcico, aluminato tricálcico, óxido tricálcico e óxido silicato. Existem, ainda, pequenas quantidades de outros óxidos minerais que são responsáveis pelas propriedades físicas e químicas desse agregado, tais como, o óxido de bismuto, que foi adicionado para tornar o material radiopaco (TORABINEJAD et al. ${ }^{163}$, 1995).

O MTA contém finas partículas hidrofílicas que endurecem na presença de umidade, dando como resultado um gel coloidal que a princípio tem um pH de 10,2, elevando-se a 12,5 após três horas, permanecendo constante. $\mathrm{O}$ gel se solidifica em menos de três horas, formando uma estrutura dura, alcançando uma maior resistência à compressão em 21 dias (70 Mpa), comparável com a do IRM e Super-EBA, mas significantemente menor que a do amálgama (311Mpa) (TORABINEJAD et al. ${ }^{163}$, 1995).

Com o uso do MTA passou-se a utilizá-lo em outras situações como em proteção pulpar direta e indireta ${ }^{3,49,50,123,155}$, pulpotomia $a^{46,76,105,144}$, reabsorções externas e internas ${ }^{81,135}$, no tratamento de dentes com rizogênese incompleta ${ }^{102,137,154,155}$, como plug apical em dentes com reabsorção apical e lesão periapical ${ }^{22,64,155}$, no reparo de fraturas dentárias ${ }^{14,135,155}$, em obturações de canais radiculares ${ }^{72,174}$, como material retrobturador na cirurgia paraendodôntica, $4,17,18,76,155,157,158,161,162,165$ e no tratamento de perfurações dentais ${ }^{2,10,23,26,30,47,52,63,74,76,99,100,115,119,122,141,153,175}$, demonstrando bons resultados.

O estudo realizado por HOLLAND et al. ${ }^{71}$ (1999), em tecido subcutâneo de ratos, mostrou similaridade de resultados entre o hidróxido de 
cálcio e o MTA. Ambos materiais determinam a formação de granulações de calcita e uma ponte de tecido mineralizado subjacente. Portanto, o mecanismo de ação do MTA seria o mesmo do hidróxido de cálcio. O óxido de cálcio do pó do MTA, ao realizar-se a preparação da pasta com água, é convertido em hidróxido de cálcio. Este, por sua vez, em contato com os fluídos tissulares se dissocia em íons cálcio e hidroxila. Os íons cálcio, reagindo com o gás carbônico dos tecidos, dão origem às granulações de calcita. Junto a essas granulações há acúmulo de fibronectina (SEUX et al. $\left.{ }^{136}, 1991\right)$, a qual permite adesão e diferenciação celular. Na seqüência tem-se a formação de tecido mineralizado.

Apesar de apresentar boas propriedades físicas e biológicas o MTA possui desvantagens, como um longo tempo para o endurecimento e custo elevado. Por este motivo é interessante conhecer a origem e composição deste material, para entender o seu comportamento e propor melhorias a partir do seu potencial, tanto das propriedades físicas como das biológicas. A busca de alternativas ao material visa também um barateamento, tornando-o mais acessível aos profissionais e conseqüentemente aos pacientes. Neste sentido, tem sido comparado com o cimento Portland.

Recentemente, o fabricante do ProRoot MTA modificou algumas informações contidas no MSDS (Material Safety Data Sheet) original, acrescentando que o material é composto por $75 \%$ de cimento Portland, $20 \%$ de óxido de bismuto e $5 \%$ de sulfato de cálcio diidratado, sendo estes dados omitidos nos trabalhos experimentais e bulas originais anteriores (BERNABÉ; HOLLAND ${ }^{17}$, 2004).

WUCHERPFENNING; GREEN ${ }^{180}$ já tinham salientado, em 1999, que o MTA e o cimento Portland são praticamente idênticos macroscópica, microscópica e radiograficamente.

A ação antimicrobiana do MTA, cimento Portland, hidróxido de cálcio, Sealapex e Dycal, e a análise dos elementos químicos presentes no MTA e em duas amostras do cimento Portland, realizada com um Espectrômetro de Fluorescência de Raios X, foram avaliados por ESTRELA 
et al. $^{48}$, em 2000. Eles relataram que o cimento Portland contém os mesmos elementos químicos principais do MTA, exceto que este último também contém óxido de bismuto. Foi relatado ainda, que o cimento Portland tem pH e atividade antimicrobiana semelhante ao MTA.

Outros trabalhos foram realizados comparando o MTA com o cimento Portland, analisando e verificando a similaridade, quando utilizados em tecido subcutâneo de ratos (HOLLAND et al. ${ }^{75}$, 2001), em pulpotomias em dentes de cães (HOLLAND et al. ${ }^{73}, 2001$; MENEZES et al. ${ }^{105}$, 2004), em obturação de canais radiculares de dentes de cães (HOLLAND et al. ${ }^{72}$, 2001), quando implantados em mandíbula de cobaias (SAIDON et al. ${ }^{131}$, 2002), em retrobturações de canais radiculares de dentes de cães (BERNABÉ; HOLLAND ${ }^{17}$, 2004). Estudos também foram realizados com intuido de verificar a biocompatibilidade dos dois materiais, e ambos mostraram-se não tóxicos e com potencial para reparo ósseo (SAFAVI; NICHOLS ${ }^{129}$, 2000; ABDULLAH et al. ${ }^{1}, 2002$; SAIDON et al. ${ }^{132}$, 2003).

A Angelus* está produzindo dois tipos de agregado de trióxido mineral, o MTA Branco com sulfato de bário e o MTA Branco com óxido de bismuto, este último lançado no mercado em janeiro de 2004. Assim, hoje encontram-se no mercado nacional o MTA-Angelus de cor cinza e o MTA Branco. O diferencial da cor se dá pela diminuição da quantidade de um de seus componentes - o trióxido de ferro - ocasionando apenas a alteração da cor, sem a perda de qualquer de uma de suas outras propriedades. Com a alteração da cor, a indicação do cimento reparador se amplia para áreas estéticas - principalmente em perfurações de dentes anteriores com limite cervical e vestibular, pulpotomias e na proteção pulpar direta (KRANZ ${ }^{91}$, 2004).

O sulfato de bário e o óxido de bismuto conferem radiopacidade ao cimento, sendo fundamental nas cirurgias parendodônticas onde o aspecto radiográfico é determinante para análise e verificação dos resultados.

\footnotetext{
*Angelus Soluções Odontológicas - Londrina, Paraná, Brasil.
} 
A aceitação do uso de um determinado produto deve ser calcada em trabalhos experimentais e laboratoriais que comprovem, entre outras propriedades, a sua biocompatibilidade. Para isso, diversas metodologias têm sido desenvolvidas de modo a elucidar com maior clareza o potencial irritante dos materiais. Uma delas, a implantação de amostras dos materiais no tecido conjuntivo de pequenos animais, é considerado teste adequado para avaliação da biocompatibilidade de materiais endodônticos (OLSSON; SLIWKOWSKI; LANGELAND ${ }^{116}$, 1981), embora seja conhecido, que as reações observadas nesses casos não podem ser consideradas réplicas daquelas encontradas nos tecidos pulpar e periapical. As normas divulgadas pela American Dental Association ${ }^{6,7,148}$ e Fédération Dentaire Internationale ${ }^{82,147,148,149}$ consideram os métodos de implante como testes válidos nas etapas preliminares de pesquisa da histocompatibilidade de diversos materiais, dentre eles, os materiais retrobturadores de canais radiculares.

Diante do exposto, parece oportuno realizar pesquisas para verificar se as propriedades biológicas e físicas desses materiais foram alteradas. 


\section{REVISÃO DA LITERATURA}

A revisão da literatura é apresentada de forma cronológica, onde se procurou abordar os estudos mais relevantes para o desenvolvimento deste trabalho. Inicialmente foram revisados os trabalhos pertinentes à metodologia empregada, à compatibilidade biológica do MTA, suas propriedades físico-químicas e, finalmente, as pesquisas que compararam o MTA com o cimento Portland.

\subsection{Da implantação subcutânea}

TORNECK $^{167}$, em 1966, foi o primeiro a introduzir os tubos de polietileno em pesquisas de implantação subcutânea. Ele avaliou a reação do tecido conjuntivo subcutâneo de ratos frente à implantação de tubos de polietileno, relacionando a reação do tecido com o diâmetro e o comprimento dos tubos. Antes da implantação, os tubos foram desinfetados em solução de iodo, lavados em solução salina, secos com gazes estéreis e armazenados em tubos também estéreis até seu uso. Em um grupo os tubos foram mantidos com as duas extremidades abertas e no outro uma das extremidades foi fechada termicamente. Após 60 dias de implantação, os animais foram mortos, os implantes e os tecidos adjacentes foram conduzidos ao processamento histológico. Os resultados mostraram a formação de uma cápsula fibrosa que envolvia os implantes, rica em fibroblastos e fibras colágenas. Segundo o autor a ausência de inflamação no tecido conjuntivo capsular indica a aceitabilidade do material, um dos objetivos do teste. $\mathrm{O}$ diâmetro e o comprimento dos tubos parecem influenciar no reparo, criando um ambiente favorável para o reparo. Quanto mais comprido ou mais estreito for o tubo, mais dificilmente ocorre a invaginação do tecido conjuntivo para o seu interior. Nos tubos em que uma das extremidades foi selada, a invaginação ocorreu primeiro nos de pequeno diâmetro, indicando que alguns fatores influenciam no crescimento do tecido conjuntivo e são diferentes em cada sistema. $O$ autor concluiu que os 
resultados obtidos neste estudo indicam que os canais radiculares não obturados, porém completamente limpos e desinfetados, propiciam a cura dos tecidos periapicais.

Um ano depois, PHILLIPS ${ }^{121}$ (1967) avaliou a resposta tecidual a tubos de polietileno vazios implantados em subcutâneo de ratos. Os tubos tinham 6, 10 e $15 \mathrm{~mm}$ de comprimento e seis diâmetros diferentes para cada comprimento $(0,59 ; 0,77 ; 1,0 ; 1,2 ; 1,4$ e 1,7mm). Alguns tubos foram selados em ambas as extremidades e serviram como controle. Antes da implantação os tubos foram desinfetados pela imersão em cloreto de benzalcônio 1:1000 por $24 \mathrm{~h}$. Ratos Wistar com peso de aproximadamente 160 a $200 \mathrm{~g}$ foram utilizados neste estudo. Os animais foram anestesiados e as áreas a serem implantadas receberam depilação e desinfecção. Quatro tubos com 4 secções diferentes foram implantados em cada rato. Os animais foram mortos 60 dias após o implante e os blocos de tecido contendo os tubos foram removidos e fixados em solução de formalina a 10\%, desidratados em álcool etílico e clarificados em acetona e clorofórmio. Procedeu-se a inclusão em parafina e cortes seriados de $6 \mu \mathrm{m}$ de espessura, no sentido longitudinal do tubo de maneira a visualizar as suas duas extremidades, e foi utilizada a coloração H.E.. Os resultados mostraram que ao redor dos tubos houve a formação de uma cápsula fibrosa rica em fibroblastos e fibras colágenas, além de poucas células plasmáticas e monócitos e uma pequena reação inflamatória nas extremidades dos tubos. Também não foi verificada a presença de necrose. Verificou-se nos tubos menores e de maior diâmetro uma maior invaginação de tecido conjuntivo.

No mesmo ano, TORNECK ${ }^{168}$ (1967) investigou a reação do tecido conjuntivo de ratos a tubos de polietileno com fragmentos de músculo contaminados e comparou com a reação de tubos de polietileno com os mesmos fragmentos musculares, porém estéreis. Tubos de polietileno de variados comprimentos e diâmetros foram implantados cirurgicamente no dorso dos animais. Antes da implantação os tubos foram desinfetados em 
solução de iodo, depois lavados em solução salina, secos com gazes e armazenados em tubos estéreis até o uso. Em um grupo os tubos foram mantidos com as duas extremidades abertas e no outro, uma das extremidades foi termicamente fechada. Alguns tubos selados em uma das extremidades foram preenchidos com fragmento de tecido muscular da perna traseira do rato e colocados em solução salina para serem autoclavados e outros foram preenchidos com o mesmo tecido muscular, só que contaminados com cocos Gram-negativos. Após 60 dias os animais foram mortos e o tecido contendo o tubo foi removido e preparado para análise microscópica. As colorações utilizadas foram H.E., Giemsa e Gram. Os resultados indicaram que o prognóstico de reparo foi menos favorável quando o lume foi preenchido com os debris musculares contaminados. Em ambas as condições do tubo preenchido (contaminado ou não), o reparo foi menos favorável do que quando o tubo estava estéril sem preenchimento algum.

Alguns métodos para se avaliar as respostas biológicas aos materiais endodônticos foram estudados por LANGELAND et al. ${ }^{95}$, em 1969. Os autores realizaram implantes de pasta $\mathrm{N}_{2}$ em tecido subcutâneo de nove ratos adultos. Incisões horizontais de $1 \mathrm{~cm}$ foram realizadas na região interescapular, pélvica e abdominal e os tubos de polietileno preenchidos com a pasta $\mathrm{N}_{2}$ foram inseridos nestas, que foram em seguida suturadas. Após os períodos de 14 e 77 dias os animais foram mortos e os tecidos preparados para análise microscópica. Os resultados mostraram que no período de 14 dias o tecido conjuntivo em contato com a pasta apresentava inflamação aguda com intenso infiltrado neutrofílico, macrófagos e células gigantes. Já o tecido conjuntivo em contato com o tubo de polietileno mostrou a presença de fibrócitos. Aos 77 dias os resultados mostraram inflamação crônica caracterizada pela presença de linfócitos e macrófagos. Houve também a presença de fibrócitos, especialmente nas regiões de contato com o tubo de polietileno. Os autores concluíram que o teste de implantação em tecidos moles tem um valor limitado devido à 
impossibilidade de avaliá-lo na dentina e no osso alveolar. Concluíram ainda que o teste da implantação deve ser apenas de caráter preliminar e de curta duração e que testes em dentes devem ser realizados para avaliações decisivas.

OLSSON; SLIWKOWSKI; LANGELAND ${ }^{116}$, em 1981, avaliaram por meio do método de implantação subcutânea em ratos, a biocompatibilidade de vários materias endodônticos, com o objetivo de enquadrá-los em níveis de toxicidade. Para isso empregaram tubos de teflon preenchidos com os materiais em teste: a cloropercha $N ø$, Kerr sealer e o AH-26. Foram utilizados 42 ratos da raça Sprague-Dawley com peso variando entre 350 a 450 gramas. Os tubos de teflon de $7 \mathrm{~mm}$ de comprimento por $1,3 \mathrm{~mm}$ de diâmetro, foram esterilizados, preenchidos com os cimentos e implantados nos ratos. Os animais foram mortos após períodos de 14, 30, 90 e 180 dias, e as peças removidas e preparadas para análise microscópica. Cortes seriados de $5 \mu \mathrm{m}$ foram obtidos e corados com H.E., Tricômico de Masson e Brown \& Breen. A localização do material, o estado dos tecidos nas extremidades do tubo, a ocorrência e a localização de tecido necrótico e fibroso, os tipos de células inflamatórias e as trocas vasculares foram observadas e registradas. A reação tecidual foi classificada como suave, moderada ou severa. Aos 14 e 30 dias, observou-se partículas do material dispersas no tecido que envolvia os tubos, em vasos sangüíneos, em macrófagos e como corpo estranho no interior de células gigantes. Outro achado comum foi a presença de células inflamatórias crônicas com a formação de uma cápsula fibrosa contornando os materiais implantados. Aos 180 dias a inflamação crônica ainda persistiu. Vasos sangüíneos e corpos estranhos no interior de células gigantes foram achados muito freqüentes neste período. Os autores concluíram que o teste foi adequado para a avaliação qualitativa dos materiais endodônticos, mas que a classificação de biocompatibilidade dos materiais só poderia ser considerada entre materiais com grande diferença de toxicidade. 
ZANONI et al. ${ }^{183}$ (1988) compararam a resposta do tecido conjuntivo subcutâneo de ratos frente ao implante de tubos de polietileno e de dentina, obturados com Endomethasone. Foram utilizados 54 ratos, divididos em dois grupos, sendo que o grupo A recebeu implantes de tubos de polietileno com $1 \mathrm{~cm}$ de comprimento e $0,5 \mathrm{~cm}$ de diâmetro interno e o grupo B recebeu tubos de dentina, preparados a partir da raiz palatina de molares superiores, seccionados com as mesmas medidas. Cada grupo foi subdividido em 3 subgrupos (A1, A2, A3, B1, B2 e B3). Os tubos foram autoclavados a $120^{\circ} \mathrm{C}$, por 20 minutos e obturados com cones de gutapercha e o referido cimento. No subgrupo A1 e B1 foi deixado 0,5 a 1,0mm de espaço vazio em uma das extremidades; nos subgrupos A2 e B2 de 1,5 a $2 \mathrm{~mm}$ e nos subgrupos A3 e B3 4mm. Decorridos 7, 21 e 60 dias pósoperatório, os animais foram mortos, e as peças removidas foram preparadas para análise microscópica. Os cortes semi-seriados com $6 \mu \mathrm{m}$ de espessura foram corados com H.E.. Todos os subgrupos, os quais receberam tubos de polietileno, apresentaram invaginação de tecido de granulação, com grau mais acentuado de infiltrado inflamatório nos períodos de 7 e 21 dias nos subgrupos A2 e A3 e de grau mais moderado no A1. Nestes mesmos períodos, quando utilizaram tubos de dentina, este tecido foi observado nos subgrupos B1 e B2 com infiltrado inflamatório de grau discreto a moderado. Contudo, o subgrupo B3 apresentou inflamação de grau moderado a intenso com prevalência linfoplasmocitária. Os subgrupos A3 e B3, em todos os períodos, apresentaram uma concentração de exsudato nos espaços vazios em contato com o material obturador e persistente reação inflamatória. No período de 60 dias, os subgrupos $A 1, A 2$, B1 e B2 apresentaram discreto infiltrado inflamatório. Portanto, os tubos de dentina de menor espaço vazio foram os que apresentaram melhor evolução por colagenização.

ECONOMIDES et al. $^{44}$ (1995) estudaram in vivo a biocompatibilidade de quatro cimentos obturadores, dois contendo hidróxido de cálcio (CRCS e Sealapex), um a base de óxido de zinco e eugenol (Roth 
811) e um à base de resina epóxica $(\mathrm{AH} 26)$. Analisaram também a influência dos componentes dos cimentos sobre as concentrações de cálcio e zinco em alguns órgãos. Foram utilizados 75 ratos Wistar-Furth, divididos em cinco grupos de cinco animais para cada período experimental. Tubos de teflon com $5 \mathrm{~mm}$ de comprimento e $1,6 \mathrm{~mm}$ de diâmetro interno contendo os materiais foram implantados nos tecidos subcutâneos, tomando cuidado para evitar que o material se espalhasse pelo tecido. Tubos vazios foram utilizados como controle e as incisões foram suturadas com fio cirúrgico. Decorrido os períodos experimentais de 7, 14 e 21 dias, os animais foram mortos pela inalação de éter, os tubos removidos juntamente com o tecido adjacente e fixados em formalina $10 \%$ e preparados para análise microscópica. Cortes seriados de $6 \mu \mathrm{m}$ de espessura foram obtidos e corados com H.E. e Brown \& Breen. A reação inflamatória foi graduada em leve, moderada e severa. Para análise do cálcio e zinco, 25 animais foram mortos uma semana após a implantação dos tubos, sendo o fígado, cérebro, rins e útero removidos e analisados pelo método de espectrofotometria. Embora o cimento $\mathrm{AH} 26$ não contenha cálcio em sua composição, os valores da concentração de cálcio aumentaram, em todos os órgãos examinados, quando comparado ao grupo controle. Nos animais, onde foram utilizados o cimento CRCS e o Sealapex, não apresentaram modificações nas concentrações de cálcio, em todos os órgãos examinados. Com relação ao zinco, altas concentrações foram observadas nas amostras teciduais obtidas dos animais dos grupos do CRCS e Roth 811. O material que apresentou maior inflamação no período de sete dias foi o $\mathrm{AH} 26$, entretanto, a intensidade da irritação diminuiu após 21 dias. Os cimentos Roth 811 e Sealapex apresentaram inflamação moderada a severa em todos os períodos. A inflamação moderada, ocorrida com o CRCS, aos sete dias, diminuiu gradualmente até os 21 dias.

\footnotetext{
KOLOKURIS et al. $^{89}$ (1996) compararam in vivo a biocompatibilidade dos cimentos Ketac-Endo e o Tubli-Seal quando implantados em tecido subcutâneo de 44 ratos Wistar-Furth. Os períodos
} 
experimentais foram de 5, 15, 60 e 120 dias. Para cada período havia um grupo controle. Após anestesia e desinfecção da área com álcool iodado a $5 \%$, foram feitas incisões no dorso de cada animal e duas bolsas foram preparadas com aproximadamente $15 \mathrm{~mm}$ de profundidade. Tubos de teflon com $5 \mathrm{~mm}$ de comprimento e $1,6 \mathrm{~mm}$ de diâmetro interno contendo os materiais recém manipulados, foram implantados nos interior dessas bolsas. Ao final de cada período experimental os animais foram mortos por inalação de éter. Os tubos foram removidos juntamente com os tecidos adjacentes e fixados em formalina $10 \%$ por $48 \mathrm{~h}$, e as peças preparadas para análise microscópica. Foram realizados cortes seriados de seis micrometros de espessura corados por H.E. e pelo Brown \& Brenn para evidenciar possíveis microrganismos. Os tipos celulares observados e a resposta inflamatória foram classificados em leve, moderada e severa. Uma reação discreta foi observada com o Ketac-Endo em cinco dias, sendo que o tecido adjacente apresentou plasmócitos, linfócitos e macrófagos. A intensidade diminuiu em 15 dias e continuou progressivamente diminuindo em 60 e 120 dias. Já para - Tubli-Seal, o tecido apresentou severa inflamação com diferentes extensões de necrose em 5 e 15 dias, apresentando-se irritante em 60 e 120 dias. Os autores concluíram que o Ketac-Endo é um material compatível e bem tolerado pelos tecidos.

KOLOKOURIS et al. $^{90}$ (1998), avaliaram, in vivo, a biocompatibilidade do Apexit e Pulp Canal Sealer após implantação no tecido conjuntivo subcutâneo de ratos. Quarenta e quatro ratos Wistar-Furth foram utilizados. Cada cimento foi colocado em tubos de teflon e implantados em locais específicos do dorso do animal. Os implantes foram removidos após 5, 15, 60 e 120 dias, fixados e preparados para avaliação microscópica. O estado do tecido adjacente, a ocorrência e localização do tecido fibroso, os vários tipos de células inflamatórias e as alterações vasculares foram examinados. A reação tecidual foi graduada em leve, moderada e severa. Reações inflamatórias severas com diferentes extensões foram observadas com o Apexit ao quinto e décimo dias. A 
intensidade da reação diminuiu progressivamente até o centésimo vigésimo dia. Foi caracterizado pela presença de tecido conjuntivo com poucos macrófagos. Nos espécimes de Pulp Canal Sealer foi observada inflamação de moderada a severa ao quinto dia. A intensidade da reação diminuiu aos 15, 60 e 120 dias, mas permaneceu levemente maior que nos espécimes com Apexit nos períodos de observação maiores.

GORDUYSUS; ETIKAN; GOKOZ $^{60}$, em 1998, avaliaram a biocompatibilidade do Endo-Fill囚 quando implantado no tecido subcutâneo de ratos. Utilizaram 15 animais e quarenta tubos de polietileno de $10 \mathrm{~mm}$ de comprimento e 1,6mm de diâmetro. Após anestesia e anti-sepsia foram realizadas quatro bolsas na região dorsal de cada animal, onde os tubos preenchidos com o material foram implantados. Um dos animais recebeu implante de quatro tubos de polietileno vazios como controle. Passado os períodos de 2, 7, 14, 28 e 56 dias os animais foram mortos, e as peças preparadas para análise microscópica, realizando-se cortes seriados de $6 \mu \mathrm{m}$ de espessura e coloração por H.E.. Após análise dos resultados, os autores observaram que ao final do período de 8 semanas houve a formação de uma fina camada de tecido conjuntivo ao redor do material e avançado processo de reparo, sem a formação de cápsula fibrosa e qualquer reação inflamatória neste período.

\subsection{Das propriedades do MTA}

Como foi salientado no Capítulo de Introdução, o MTA tem sido indicado para várias modalidades de tratamento, por esse motivo, procuramos aqui mostrar pesquisas que suportam tais funções. Chamamos atenção para os resumos dos artigos que falam da citotoxicidade e biocompatibilidade do MTA. 
O primeiro trabalho referente ao Agregado Trióxido Mineral (MTA) data de 1993, quando LEE; MONSEF; TORABINEJAD ${ }^{96}$, da Universidade de Loma Linda (Loma Linda, Califórnia - EUA), desenvolveram um cimento com o propósito de selar as comunicações entre o sistema de canais radiculares e o periodonto. Neste trabalho, compararam a capacidade de selamento do MTA, amálgama e IRM em perfurações de dentes humanos extraídos. Cinqüenta molares inferiores e superiores foram utilizados e as perfurações realizadas a partir da embocadura do canal na raiz mesial com broca esférica número 2 , de haste longa, em ângulo de $45^{\circ}$ do longo eixo de cada dente. O local da perfuração foi ampliado com uma lima $K \mathrm{n}^{\circ} 80$, até que sua ponta ultrapassasse $5 \mathrm{~mm}$ da superfície radicular. Os dentes foram divididos aleatoriamente em quatro grupos e as perfurações, seladas como segue: grupo I - 15 dentes com amálgama, grupo II - 15 dentes com IRM; grupo III - 15 dentes com MTA e grupo IV - 5 dentes sem selamento, que serviram como controle positivo. Após o preenchimento das perfurações, os dentes foram mantidos em solução salina por quatro semanas. Os resultados mostraram que o material que apresentou menor infiltração foi o MTA $(0,28)$, seguido do IRM $(1,30)$ e o amálgama $(1,53)$.

Em 1994, TORABINEJAD et al. ${ }^{158}$, compararam a infiltração marginal, em presença ou ausência de sangue, em cavidades apicais preenchidas com amálgama, Super EBA, IRM e MTA. O estudo foi realizado em 90 dentes humanos extraídos, instrumentados e obturados, com exceção dos $2 \mathrm{~mm}$ apicais, que foram seccionados com inclinação de $90^{\circ}$ e uma cavidade apical de $2 \mathrm{~mm}$ de profundidade, preparada com uma broca $\mathrm{n}^{\circ} 331$ em alta rotação. Cinco cavidades foram preenchidas com guta-percha sem cimento e outras cinco, com cera em bastão, que serviram como controles positivo e negativo, respectivamente. Os dentes foram divididos aleatoriamente em grupos de 10, na presença e ausência de sangue, no momento da colocação dos materiais em teste. Imediatamente foram imersos em solução corante azul de metileno a 1\%, por 72 horas. As raízes foram cortadas e a penetração linear do corante dentro da cavidade apical 
foi avaliada utilizando o estereomicróscopio. A presença ou ausência de sangue não teve efeito significativo sobre a infiltração do corante, porém houve diferença significativa entre os materiais. O MTA mostrou infiltração menor do que os outros materiais, com ou sem contaminação de sangue.

HONG et al. ${ }^{79}$, em 1994, avaliaram histologicamente a resposta tecidual frente a perfurações de furca seladas com amálgama (AM) ou agregado de trióxido mineral (MTA). Após a terapia endodôntica, foram realizadas perfurações na furca de 32 terceiros e quartos pré-molares de seis cães da raça Beagle. Metade das perfurações foram mantidas abertas por quatro semanas para que se desenvolvessem lesões de furca, sendo que, passado esse período, foram seladas com amálgama ou MTA. A outra metade das perfurações foi selada imediatamente com os mesmos materiais. Depois de quatro meses, os animais foram mortos. A análise estatística das radiografias pré e pós-operatórias mostrou que as perfurações seladas com MTA cicatrizaram significantemente melhor do que aquelas seladas com amálgama. Análises histomorfométricas demonstraram que as perfurações seladas com amálgama apresentaram mais inflamação e reabsorção óssea quando comparadas ao grupo do MTA. Os autores concluíram que o MTA é um material que pode ser utilizado em selamentos de furca.

PITT FORD et al. ${ }^{122}$, em 1995, realizaram 28 perfurações intencionadas, em pré-molares inferiores de sete cães, com o propósito de avaliar a resposta do tecido perirradicular na região de furca. Metade dos dentes tiveram as perfurações seladas imediatamente com amálgama e MTA e a outra metade, as perfurações foram contaminadas com saliva e deixadas abertas ao meio bucal por 6 semanas, para posteriormente serem seladas com amálgama e MTA. Os animais foram sacrificados após quatro meses e as peças, analisadas microscopicamente. Os resultados mostraram que os dentes selados imediatamente com o amálgama, tiveram inflamação de moderada a severa, enquanto que com o MTA ocorreu a formação de 
novo cemento em cinco, de seis dentes. Os dentes contaminados e selados com o amálgama mostraram áreas de inflamação e com o MTA, 3 estavam livres dela e 4 com áreas inflamadas. Com base nesses resultados, os autores concluíram que o MTA é mais conveniente que o amálgama para o reparo de perfurações, especialmente quando estas, foram seladas imediatamente.

TORABINEJAD et al. ${ }^{160}$, em 1995, realizaram um estudo in vitro para avaliar a citotoxicidade do MTA, amálgama, Super-EBA e IRM, pois esses materiais quando utilizados em obturações retrógradas ficam em íntimo contato com os tecidos perirradiculares e assim é importante que sejam biologicamente compatíveis. Para o estudo foram utilizados fibroblastos de camundongos do tipo L929 e os métodos de cobertura com ágar e liberação de radiocromo. A análise estatística dos resultados com a técnica de cobertura com ágar mostrou que o amálgama tanto recémmisturado, quanto após a reação de presa, foi significantemente menos tóxico que os outros materiais testados. O MTA alcançou o $2^{\circ}$ lugar. Após 24 horas de incubação das células de camundongos do tipo L929 marcadas com radiocromo, a análise estatística também revelou uma diferença significante entre a toxicidade dos materiais estudados tanto antes como após a reação da presa. Neste caso o MTA foi o material menos tóxico, seguido pelo amálgama, Super-EBA, e IRM. Baseado nos resultados obtidos com os métodos de cultura de células, os autores acreditam que o MTA seja um material com potencial para uso em retrobturação permitindo assim avaliações do mesmo in vivo.

Em 1995, KETTERING e TORABINEJAD ${ }^{86}$ investigaram o potencial mutagênico do IRM e do Super-EBA, os quais são materiais indicados para obturações retrógradas, comparando-os ao MTA. No estudo foram utilizados o teste de mutagenicidade de Ames e cepas de Salmonella typhimurium LT-2 que são bactérias sensíveis a diferentes classes de mutagênicos. Os resultados mostraram que nenhum material avaliado 
mostrou qualquer efeito mutagênico. Os autores concluíram que o material ideal para obturação retrógrada deve apresentar boa estabilidade dimensional e não ser mutagênico. Concluíram ainda que todos os materiais testados não apresentaram efeito mutagênico por efeito potencial direto ou indireto. Os autores concluíram que, pelo fato de o MTA proporcionar um selamento superior quando comparado a outros materiais normalmente empregados para obturação retrógrada e ainda por ser menos citotóxico e não mutagênico, é interessante a realização de estudos in vivo antes da indicação clínica do mesmo.

TORABINEJAD et al. ${ }^{164}$, em 1995, realizaram um estudo para avaliar a reação tecidual frente à implantes de Super-EBA e MTA em mandíbulas de sete porquinhos da Índia. Após anestesia, foram aberto retalhos no tecido e preparadas em cada animal duas cavidades ósseas de $2 \mathrm{~mm}$ de diâmetro e $2 \mathrm{~mm}$ de profundidade. Os materiais a serem testados foram então colocados em tubos de teflon e implantados nas mandíbulas de seis animais. Duas cavidades ósseas foram deixadas vazias e usadas como controles negativos. Após 2 meses os animais foram mortos e as peças processadas para análise microscópica. Foram avaliadas a presença de inflamação, o tipo celular predominante e a espessura do tecido conjuntivo fibroso adjacente a cada implante. Como resultado, observou-se que a reação tecidual ao implante de MTA foi pouco menor que a observada com o implante de Super-EBA. Todas as amostras do Super-EBA apresentavam tecido conjuntivo fibroso próximo ao cimento, entretanto, no grupo do MTA, foi observado tecido ósseo adjacente ao implante em 1 das 5 lâminas. Foi observada uma inflamação leve em todos os implantes de Super-EBA, porém, 3 dos 5 implantes de MTA estavam livres de inflamação. As células inflamatórias encontradas ao redor de ambos materiais eram predominantemente macrófagos e células gigantes. O tecido conjuntivo fibroso adjacente ao implante de Super-EBA era mais fino que do implante de MTA. Baseados nos resultados desse estudo, os autores concluem que os dois materiais parecem ser biocompatíveis. 
A resposta dos tecidos periapicais de cães ao MTA e ao amálgama foi investigada por TORABINEJAD et al. ${ }^{162}$, em 1995 . Foram utilizados os terceiros e quartos pré-molares inferiores de 6 cães da raça Beagle. Após a abertura coronária e preparo químico-mecânico dos canais radiculares, estes foram deixados abertos e expostos às bactérias orais por 2 semanas e então selados com Cavit por mais 4, para o desenvolvimento de lesões periapicais. No grupo I (12 dentes) os canais foram modelados e obturados com guta-percha e cimento Roth ${ }^{\circledR}$, e as cavidades de acesso seladas com MTA. No grupo II (12 dentes) após a modelagem os canais foram obturados somente com guta-percha, sem o cimento obturador, e as cavidades de acesso não foram seladas, ficando expostas ao meio oral. Entre 1 e 2 semanas pós-obturação, os dentes foram submetidos a apicectomias e retrobturações com amálgama ou MTA. Depois de 2, 5, 10 e 18 semanas os animais foram mortos. As peças foram processadas e submetidas a análise microscópica. Avaliou-se a severidade e extensão da inflamação, o tipo de células inflamatórias predominantes no tecido perirradicular adjacente aos materiais retrobturadores, a presença ou ausência de cápsula fibrosa, a deposição de cemento, de periósteo, a neoformação óssea e a contaminação bacteriana. Os resultados mostraram que os tecidos perirradicular de todas as raízes obturadas com amálgama tinham inflamação de moderada a severa, enquanto somente $1 / 3$ das obturadas com MTA tinham inflamação moderada. Observou-se que no período de 2 a 5 semanas houve predomínio de leucócitos no grupo do amálgama, e de linfócitos no grupo do MTA. Já com 10 a 18 semanas nos 2 grupos os linfócitos predominaram. Não houve formação de cápsula fibrosa sobre o amálgama, estando a mesma presente em 19 das 21 amostras onde o MTA foi utilizado. No período de 2 a 5 semanas, ocorreu a formação de cemento em 1 das 11 amostras do MTA e no período de 10 a 18 semanas todas apresentaram (10 amostras), enquanto que no grupo do amálgama nenhuma formação de cemento foi evidenciada. Os autores concluíram que tanto o tipo de obturação do canal como o selamento ou não da cavidade de acesso influenciaram na formação de cemento sobre a área da raiz 
seccionada. Segundo os autores, o MTA provavelmente é capaz de induzir a ativação de cementoblastos, formando uma matriz para a neoformação cementária, além de sua excelente capacidade seladora, elevado $\mathrm{pH}$ e a liberação de substâncias capazes de ativar a cementogênese.

SOARES $^{144}$ (1996) avaliou microscopicamente a resposta pulpar após a pulpotomia de 12 dentes de cães seladas com MTA e com hidróxido de cálcio. Decorrido o período de 90 dias, os animais foram mortos e as peças processadas para análise microscópica. Os cortes foram feitos seriadamente, com $6 \mu \mathrm{m}$ de espessura e corados pela hematoxilina e eosina. A autora observou que a formação da barreira de tecido mineralizado ocorreu em $91,66 \%$ dos dentes tratados com hidróxido de cálcio e em $96,43 \%$ dos casos em que o MTA foi utilizado. Os percentuais de casos que apresentaram, simultaneamente, barreira de tecido mineralizado e tecido pulpar normal foi de $66,66 \%$ dos espécimes tratados com hidróxido de cálcio, e de $82,14 \%$ nos dentes em que se utilizou o MTA.

Os efeitos do MTA e do hidróxido de cálcio (Dycal) em capeamentos pulpar diretos foram avaliados por MYERS et al. ${ }^{113}$ em 1996. Pequenas exposições pulpares foram realizadas em dentes de cães e capeadas pelos materiais em estudo. As cavidades de acesso foram restauradas com amálgama. Após 90 dias a viabilidade pulpar de 16 dentes capeados com MTA e 15 com Dycal foi avaliada histologicamente. Áreas de exposição de nove dentes capeados com MTA e 11 com Dycal também foram avaliadas quanto à extensão e qualidade da ponte de dentina formada. Os resultados mostraram não haver diferença significante entre os materiais de acordo com os critérios adotados. Os autores concluíram que tanto o MTA como o Dycal tiveram bom desempenho como materiais capeadores, foram biocompatíveis ao tecido pulpar e estimularam a deposição de dentina nas pequenas exposições. 
O desempenho do MTA e hidróxido de cálcio (Dycal) como materiais capeadores diretos da polpa dental de cães e macacos foi estudado por ABEDI et al. $^{3}$ em 1996. As exposições pulpares foram imediatamente recobertas por um dos materiais e as cavidades de acesso restauradas com amálgama. Após 2 a 5 meses pós-capeamento os animais foram mortos, as coroas dentais removidas, fixadas em formol, e descalcificadas em EDTA. Cortes longitudinais seriados de $5 \mu \mathrm{m}$ foram realizados na área pulpar capeada e corados com H.E.. A quantidade de formação de tecido mineralizado e o grau de inflamação da polpa foram analisados por histometria computadorizada. Os resultados mostraram maior formação de ponte de tecido mineralizado e menor inflamação no grupo do MTA quando comparado ao grupo do $\mathrm{Ca}(\mathrm{OH})_{2}$. Os autores concluíram que, aparentemente, o MTA pode ser usado como material capeador pulpar direto.

PITT FORD et al. ${ }^{123}$, em 1996, compararam a resposta da polpa dental de macacos ao hidróxido de cálcio (Dycal) e ao MTA quando utilizados como materiais capeadores. No estudo foram utilizados 12 incisivos inferiores. Depois de isolados com dique de borracha, foram realizadas exposições pulpares padronizadas de um milímetro de diâmetro com brocas esféricas $\mathrm{n}^{\circ} 1 \mathrm{em}$ alta rotação. $\mathrm{O}$ sangramento foi controlado com bolinhas de algodão esterilizadas e só então foi aplicado o material capeador. As cavidades do grupo do hidróxido de cálcio foram restauradas com amálgama, e as cavidades do grupo do MTA foram totalmente preenchidas por este material. Após 5 meses, os animais foram mortos e foi realizado o processamento histológico, utilizando as colorações de H.E. e Brown \& Breen. Os resultados mostraram que todas as 6 polpas capeadas com MTA apresentavam ponte de dentina adjacente ao material, sendo esta espessa e contínua à dentina original, com túbulos dentinários, ausência de defeitos tipo túnel ou de inclusões de tecido mole. Apenas uma das 6 polpas do grupo do MTA estava inflamada. Em contraste, das 6 polpas capeadas com Dycal somente dois apresentavam ponte de dentina e todas estavam 
inflamadas severamente e com predominância de leucócitos polimorfonucleares. Segundo os autores, este quadro deve-se provavelmente à infiltração na interface amálgama estrutura dental e à diluição do Dycal. Não foram observadas bactérias nas paredes cavitárias de nenhum dente do grupo do MTA, o que não aconteceu com o grupo do hidróxido de cálcio, onde foram observadas em 1 dente. A ausência de infiltração bacteriana no grupo do MTA é resultado provavelmente de sua lenta reação de presa, que faz com que sua contração seja pequena, e também por sua solubilidade, que é praticamente nula. Os autores concluem que o MTA é um material conveniente para proteção pulpar direta.

TORABINEJAD et al. ${ }^{165}$ (1997) avaliaram a resposta dos tecidos periapicais após retrobturação com MTA e amálgama. Foram utilizados 12 dentes incisivos maxilares de 3 macacos. Os dentes foram instrumentados e obturados com cones de guta-percha e cimento, e as cavidades de acesso restauradas com amálgama. A seguir, foram realizadas apicectomias e as cavidades apicais foram preparadas. Metade dos dentes de cada animal, foram retrobturados com amálgama e a outra metade com MTA. Após 5 meses os animais foram mortos e a resposta tecidual perirradicular foi avaliada histologicamente. Dos 6 espécimes preenchidos com MTA, apenas um mostrou inflamação periapical severa. Em todos os 5 espécimes sem inflamação, havia uma camada de cemento sobre o MTA e fibras periodontais podiam ser observadas inseridas nesse cemento em alguns locais. Em contraste, todos os 6 espécimes preenchidos com amálgama apresentaram inflamação periapical (2 moderada e 4 severa). As células inflamatórias mais comumente encontradas nesse grupo foram os linfócitos, facilmente observados próximo ao material. Cápsula fibrosa foi observada recobrindo o material retrobturador, não sendo encontradas bactérias em nenhum dente de ambos os grupos. Houve formação óssea,em ambos os grupos, no local da loja cirúrgica que foi realizada para permitir a apicectomia. 
KOH et al. ${ }^{87}$, em 1997, estudaram a ação do MTA na produção de citocinas em osteoblastos humanos e se o mesmo permitia uma boa aderência das células à superfície do material. Para o estudo, utilizaram um meio de cultura para osteoblastos (MG-63), onde foi colocado o MTA e o Polimetilmetacrilato (PMA - cimento usado comumente na ortopedia) e como grupo controle, placas de células sem presença de MTA. Os resultados mostraram crescimento celular na superfície do MTA a partir de 6 horas e incrementando-se até 144 horas, ao contrário das sem MTA ou na presença de PMA, que produziram quantidades não detectáveis de células. Os ensaios de ELISA mostraram níveis aumentados de todas as

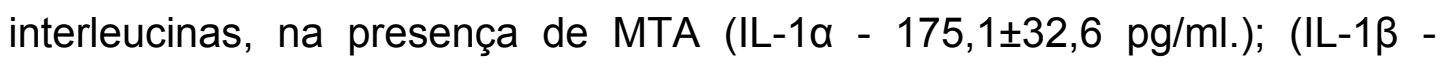
$154,0 \pm 26,7 \mathrm{pg} / \mathrm{ml}$.); (IL6 - 214,7 $\pm 21,8 \mathrm{pg} / \mathrm{ml}$.), em contraste com o PMA, enquanto que sem a presença de MTA, produziram um conteúdo insignificante de citocinas.

A citoxicidade de alguns materiais utilizados para obturação de canais radiculares e para obturação retrógrada foi avaliada por OSORIO et al. ${ }^{118}$ em 1998. Para tal, foi realizado um estudo in vitro, com culturas de células de fibroblastos gengivais humanos e células de rato L-929. Os cimentos obturadores de canais testados foram o Endomet, o CRCS e o AH26, e os retrobturadores foram o amálgama, o Gallium GF2, o Ketac Silver, o Super-EBA, o MTA e o adesivo dentinário All Bond 2. As análises estatísticas dos resultados mostraram que, o CRCS foi o cimento obturador menos tóxico, seguido pelo Endomet e AH-26. Com relação aos materiais utilizados para obturação retrógrada, o MTA não foi citotóxico, o Gallium GF2 foi pouco citotóxico e o Ketac Silver, o Super-EBA e o amálgama apresentaram elevada citoxicidade. $\mathrm{O}$ All Bond 2 também apresentou alto grau de citoxicidade, sendo todos os materiais testados citotóxicos, exceto o MTA.

JUNN et al. ${ }^{83}$ (1998) avaliaram a quantidade de dentina formada quando do emprego do MTA e do hidróxido de cálcio em capeamentos 
pulpares. Foram utilizados 63 dentes de cães da raça Beagle, que sofreram exposição pulpar e capeamento com MTA ou pasta de hidróxido de cálcio mais amálgama. Os animais foram mortos nos períodos de 1, 2, 4 e 8 semanas. Os espécimes foram fixados e embebidos em uma mistura de metacrilato e parafina. Cortes seriados de $6 \mu \mathrm{m}$ de espessura foram realizados e corados por hematoxilina e eosina. O grau de inflamação pulpar foi avaliado desde nulo a severo, e a quantidade de dentina formada foi avaliada empregando-se o programa Image $P R O \AA$. Os dados foram analisados estatisticamente pelo teste de Kruskall-Wallis e ANOVA. Os resultados mostraram que 30 dos 32 espécimes do grupo do MTA apresentaram ausência de inflamação, enquanto que apenas 13 dos 31 espécimes do grupo do $\mathrm{Ca}(\mathrm{OH})_{2}$ apresentaram polpa em condições normais, havendo uma diferença estatística significante. O grupo do MTA mostrou a formação de dentina após duas semanas do início do tratamento, ao passo que o grupo do $\mathrm{Ca}(\mathrm{OH})_{2}$ precisou de 4 semanas para alcançar os mesmos resultados. Após 8 semanas houve a formação de ponte de dentina em 21 dentes do grupo do MTA e em somente 2 dentes do grupo do $\mathrm{Ca}(\mathrm{OH})_{2}$, evidenciando diferenças estatisticamente significantes entre os grupos. Os autores concluíram que o MTA parece ser um material efetivo para capeamento pulpar de polpas de dentes de cães mecanicamente expostas.

Os materiais utilizados para obturação retrógrada, por ficarem em íntimo contato com os tecidos perirradiculares, precisam ser altamente biocompatíveis. Assim TORABINEJAD et al. ${ }^{166}$ (1998), estudaram a reação tecidual causada pelo implante de diversos materiais utilizados para obturação retrógrada, na mandíbula e na tíbia de porquinhos da Índia. Os materiais testados foram o MTA, amálgama, IRM e Super-EBA. Após anestesia, foram preparadas cavidades ósseas de $2 \mathrm{~mm}$ de diâmetro e de profundidade, em 20 animais nos quais os materiais foram colocados em tubos de teflon e implantados na tíbia, sendo após 10 dias o mesmo procedimento realizado na mandíbula. Os animais foram mortos 30 dias após o implante mandibular e os tecidos preparados para o exame 
microscópico. Foram analisados os seguintes itens: presença de inflamação, tipo celular predominante e espessura do tecido conjuntivo fibroso adjacente a cada implante. A avaliação foi realizada por 2 examinadores que desconheciam qual material havia sido implantado. Em ambos os locais, a reação tecidual observada após o implante do MTA foi a mais favorável, ocorrendo em todos os espécimes ausência de inflamação. Na tíbia, o MTA foi o material que mais freqüentemente mostrou aposição óssea direta (ou seja, tecido mineralizado foi observado adjacente ao implante), permitindo considerar o MTA um material biocompatível. A resposta ao IRM e ao SuperEBA foram similares e não tão favoráveis quanto ao MTA. A quantidade de inflamação adjacente ao implante de amálgama foi significantemente maior que a dos outros materiais.

Para investigar a resposta celular ao MTA, KOH et al. ${ }^{88}$ (1998) estudaram a citomorfologia dos osteoblastos na presença deste material, bem como a produção de citocinas. As citocinas são glicoproteínas de baixo peso molecular secretadas como resultado de estimulação celular e consideradas extremamente potentes, uma vez que interagem com receptores celulares, levando a mudanças na síntese do RNA celular e de proteínas, e também no comportamento celular. As citocinas estão envolvidas na coordenação do metabolismo ósseo. O estudo também tinha como objetivo explicar o motivo pelo qual o MTA parece induzir a cementogênese, investigando-se a capacidade celular de produzir uma matriz, a qual posteriormente poderia ser calcificada. Os materiais testados foram MTA e IRM, os quais foram manipulados conforme instruções do fabricante e colocados separados em placas de Petri. Os osteoblastos (linhagem celular MG-63) cresceram em confluência no meio de Eagle modificado por Hams/Dulbecco's, e foram semeados em placas que foram incubadas por 1 a 7 dias. Os espécimes foram visualizados por microscopia eletrônica de varredura. Para avaliação das citocinas, as células foram postas para crescer tanto sozinhas, quanto em placas contendo os materiais a serem testados por 1 a 144 horas. Os meios foram removidos para análise 
ELISA de interleucinas (IL-12, IL-1B, IL-6) e fator estimulador de colônias de macrófago. Os resultados da microscopia eletrônica de varredura mostraram que havia diferenças marcantes na morfologia celular entre as células cultivadas na presença do IRM, do MTA ou as que cresceram sozinhas ao $1^{\circ}$ e $3^{\circ}$ dias. As células cultivadas contra o MTA apresentavam morfologia normal, aparência achatada e estavam aderidas ao cimento, em íntimo contato com o mesmo, indicando que o MTA foi biocompatível. As células controle cresceram em confluência e as células na presença do IRM (tanto fresco, como após a presa) eram arredondadas e esparsas, indicando que o IRM é tóxico. O teste ELISA revelou níveis elevados de todas as interleucinas (que são citocinas) em todos os períodos de tempo quando as células cresceram na presença do MTA. Em contraste, quando as células cresceram sozinhas ou em contato com o IRM os níveis de interleucinas foram indetectáveis. O fator estimulador de macrófagos foi produzido pelas células independentemente do material que estava sendo testado, demonstrando que o MTA atua como um substrato biologicamente ativo para as células ósseas e estimula a produção de interleucinas.

A capacidade indutora da formação da barreira de tecido mineralizado no tratamento de dentes com rizogênese incompleta foi investigada por SHABAHANG et al. ${ }^{137}$, em 1999. Foram utilizados 64 prémolares de 4 cães da raça Beagle com 6 meses de idade. Os dentes foram expostos ao meio oral por 14 dias para o desenvolvimento de lesões periapicais. Em seguida realizou-se o preparo químico-mecânico e curativo com pasta de $\mathrm{Ca}(\mathrm{OH})_{2}$ por 1 semana. Os canais foram divididos em 4 grupos: no grupo 1, os canais foram preenchidos com O-P1 (proteína morfogenética), no grupo 2 com pasta de $\mathrm{Ca}(\mathrm{OH})_{2}$ e no grupo 3 com MTA. O grupo 4 serviu como controle negativo e os canais foram preenchidos com colágeno. A abertura coronária de todos os grupos foi selada com MTA. Os animais foram mortos após 12 semanas, e as peças foram processadas para análise microscópica, empregando-se o programa Image-Pro Plus para calcular a quantidade de tecido mineralizado formado, assim como, o grau 
de inflamação adjacente à área do tecido neoformado. Os autores concluíram que o MTA promoveu uma formação de tecido mineralizado mais intensa do que os outros materiais. Não houve diferença estatística significante na quantidade de tecido mineralizado neoformado entre os materiais testados. Da mesma forma, concluíram que não houve diferença estatística significante quanto ao grau de inflamação entre os grupos avaliados.

MITCHELL et al. ${ }^{107}$ (1999) avaliaram a biocompatibilidade de três variações de MTA, três materiais utilizados em enxerto ósseo sintético (gesso de Paris, Interpore 200 e Biogran) e do cimento de hidróxido de cálcio (Dycal), por meio do cultivo de células de osteossarcoma MG63 na presença dos materiais, observando a citomorfologia e o crescimento celular, e examinando a produção de citocinas pelas células. $O$ crescimento celular foi quantificado pela preparação de amostras $(n=6)$ a 2, 4 e 7 dias, para visualização por microscopia eletrônica de varredura, e então, foi feito um score da quantidade de material que estava recoberto por células saudáveis. A seguir, amostras de meio de cultura foram testadas usando o teste ELISA para expressão das Interleucina (IL) 1a, IL-6, IL-8, IL-11 e fator estimulador de colônia de macrófagos, que são as principais citocinas envolvidas na remodelação óssea. Esses testes foram comparados com controles onde não havia nenhum material presente, onde o meio de cultura e o soro fetal bovino não tinham sido expostos às células. Os resultados mostraram um adequado crescimento celular sobre as variações do MTA, estando muitas áreas dos materiais completamente recobertas por células, após 2 dias. O crescimento celular foi adequado também para o Biogran e para o Interpore 200, no entanto, para o Dycal foi pobre. A expressão de IL-6 advinda das células só foi evidente na presença do MTA e do Interpore 200. A interleucina 8 foi expressa em altas concentrações somente na presença do MTA. Não houve evidência de expressão de IL-1a e IL-11 com nenhum material. A produção de M-CSF foi alta para todos os materiais, sendo um pouco menor para o Dycal e o gesso de Paris. Essa citocina apresenta 
importante papel no desenvolvimento e na maturação de osteoclastos, atraindo osteoclastos para locais de reabsorção e controlando o seu funcionamento. O estudo sugere que este é um fator secretado por osteoblastos sadios, e não requer a ativação de osteoblastos, ao contrário de outras citocinas estudadas. Os autores ressaltam que o processo exato pelo qual os osteoblastos são ativados pelo MTA é ainda duvidoso. A solubilidade do MTA é mínima, mas é possível que ocorra alguma pequena diluição superficial do material, a qual estimula os osteoblastos a sintetizar IL-6 e IL-8. Outra possibilidade é que a microestrutura cristalina do MTA possa fornecer o estímulo necessário para a adesão celular, crescimento e expressão de citocinas. Concluem afirmando que as variantes do MTA são biocompatíveis e apropriadas para muitas aplicações odontológicas, onde exista contato entre o material e os tecidos vivos.

A reação dos tecidos periapicais de dentes de cães após obturação dos canais radiculares com MTA e cimento de ionômero de vidro (Ketac-Endo ${ }^{\circledR}$ ) foi investigada por HOLLAND et al. ${ }^{70}$, em 1999. Para o experimento, foram utilizados 30 canais radiculares, que após a instrumentação, foram preenchidos com Otosporin por uma semana. Decorrido este período, foram novamente irrigados e secos, sendo metade dos canais obturados com guta-percha e MTA, e a outra metade com gutapercha e Ketac-endo. Empregou-se para obturação a técnica da condensação lateral. Os animais foram mortos após 6 meses, e os espécimes removidos e preparados para análise microscópica. Realizaramse cortes seriados de $6 \mu \mathrm{m}$ de espessura e coloração por hematoxilina e eosina. Os resultados mostraram em todos os dentes selados com MTA, ausência de reação inflamatória no tecido apical (ligamento periodontal) e total fechamento do forame apical com um novo cemento. Os dentes selados com Ketac-endo mostraram apenas dois casos de fechamento apical parcial e 13 casos de ausência de fechamento bem como graus variados de reação inflamatória crônica (geralmente moderada). Os autores concluíram que, o MTA exibiu propriedades biológicas superiores ao Ketac- 
endo, tornando possível a deposição de tecido mineralizado a nível apical após obturação do canal radicular. Isto ocorre provavelmente porque o óxido de cálcio presente no MTA reage com o fluido tecidual e se transforma em hidróxido de cálcio.

Em 1999, TORABINEJAD; CHIVIAN ${ }^{155}$, descreveram as indicações e os métodos de aplicação clínica do MTA, como sendo: capeamento pulpar em caso de pulpites reversíveis, pulpotomias, apicificações, reparo de perfurações radiculares não cirúrgicas e cirúrgicas, assim como a utilização em obturação retrógrada. Vários estudos in vitro e in vivo demonstram que o MTA evita a microinfiltração, salientam suas propriedades biológicas e explicam a capacidade de neoformação de tecido mineralizado, que além de ser bactericida e bacteriostático, é biocompatível, quando colocado em contato com a polpa dental ou com os tecidos perirradiculares.

A citotoxicidade do MTA, amálgama e Super-EBA, foi avaliada por KEISER; JOHNSON; TIPTON ${ }^{85}$ em 2000. Os autores utilizaram culturas de células de fibroblastos obtidos a partir do ligamento periodontal de terceiros molares impactados extraídos. Os materiais foram manipulados conforme as recomendações dos fabricantes e divididos em dois grupos. O primeiro incluiu os materiais na sua condição de recém-manipulados e o segundo grupo envolvia os mesmos $24 \mathrm{~h}$ após a sua manipulação e mantidos a $37^{\circ} \mathrm{C}$ e $100 \%$ de umidade. Os resultados mostraram que para os materiais do grupo dos recém-manipulados a toxicidade foi maior para o amálgama seguido do Super-EBA e por último o MTA. Já no grupo dos materiais utilizados $24 \mathrm{~h}$ depois da manipulação, a maior toxicidade foi para o SuperEBA seguido do MTA e por último o amálgama. Os autores concluíram que o MTA pode ser indicado como material de obturação retrógrada nos casos em que são indicadas as cirurgias parendodônticas. 
ZHU et al. ${ }^{184}$ (2000) realizaram um estudo in vitro para observar a capacidade de adesão de osteoblastos humanos a materiais freqüentemente utilizados em obturação retrógrada, por meio de microscopia eletrônica de varredura. Os materiais testados foram IRM, MTA, resina composta e amálgama. Discos contendo os materiais retrobturadores já endurecidos foram colocados por apenas 1 dia no meio de cultura, e então analisados ao microscópio. A adesão, difusão, propagação ou expansão de células sobre a superfície de um material representam a fase inicial da função celular. A persistência de células circulares ou arredondadas com pouca ou nenhuma difusão, sugere que a superfície do material pode ser tóxica. Os resultados mostraram que os osteoblastos fixaram-se e propagaram-se sobre o MTA e sobre a resina composta formando uma monocamada de células. Sobre o amálgama, os osteoblastos fixaram-se, mas com pouca difusão de células. $\mathrm{Na}$ presença do IRM, os osteoblastos apresentaram forma circular e sem expansão. Os resultados indicaram uma resposta favorável ao MTA e à resina composta em comparação ao IRM e amálgama.

CAICEDO; BECERRA; BONILLA ${ }^{25}$ (2000) avaliaram os efeitos citotóxicos e as mudanças na morfologia de células VERO 76® quando em contato com o Calasept ${ }^{\circledR}$ (hidróxido de cálcio), Eufar ${ }^{\circledR}$ (hidróxido de cálcio) com Decadron ${ }^{\circledR}$, cones de guta-percha (Roeko ${ }^{\circledR}$ ) com hidróxido de cálcio e ProRoot ${ }^{\circledR}$ MTA. O estudo incluiu como controle positivo o óxido de zinco e eugenol e como controle negativo as células VERO 76®. A citotoxicidade foi avaliada pela viabilidade celular e sua confluência, por meio do microscópio de luz, e também pela morfologia celular, vista na microscopia eletrônica de transmissão (TEM). Após 24, 48 e 72 horas de observação, os resultados mostraram marcante citotoxicidade do Calasept ${ }^{\circledR}$, que mostrou inibição do crescimento celular de $2 \mathrm{~mm}$, assim como o ProRoot ${ }^{\circledR}$, onde a inibição foi de $1 \mathrm{~mm}$. A mistura de Eufar ${ }^{\circledR}$ (hidróxido de cálcio) com Decadron ${ }^{\circledR}$ mostrou um grau moderado de citotoxicidade, enquanto os cones de guta-percha com hidróxido de cálcio nenhuma citotoxicidade. Os autores concluíram que o comportamento de todos os materiais foi similar em todos os períodos, 
exceto para o ProRoot ${ }^{\circledR}$, o qual apresentou aumento da confluência celular em cada período observado.

DUMSHA; HOLT ${ }^{43}$, em 2000, investigaram a biocompatibilidade do ProRoot ${ }^{\circledR}$, do cimento ósseo e Super-EBA em caninos de cinco furões. Foram utilizados os dois caninos inferiores de cada animal, que após receberem tratamento endodôntico convencional tiveram os $3 \mathrm{~mm}$ radiculares apicais removidos e as cavidades retrógradas aí preparadas foram preenchidas com os materiais a serem testados. Decorrido o período de 6 semanas os animais foram mortos, as peças removidas, radiografadas e preparadas para análise microscópica. A análise radiográfica mostrou neoformação óssea adjacente aos três materiais testados. Houve reação inflamatória moderada em todos os espécimes, com a presença de macrófagos, células plasmáticas e fibroblastos. Os autores concluíram que os 3 materiais foram bem tolerados pelos tecidos periapicais, podendo ser considerados potenciais materiais retrobturadores.

WILLERSHAUSEN et al. ${ }^{177}$, em 2000 , testaram a citotoxicidade e o poder antinflamatório do MTA (Dentsply), RSA (Roeko), implantes de titânio (Straumann), Sealapex (Kerr) e amálgama (Dispersalloy/Dentsply). Fibroblastos gengivais e nasais e tumor de células epiteliais foram utilizados como sistemas de cultura. As culturas de células sem contato com os materiais serviram de controle. A vitalidade celular foi determinada pela mensuração das proteínas e contagem de células por meio de um microscópio de fluorescência. Os resultados mostraram que o valor do conteúdo protéico diminuiu significantemente em contato com o MTA e RSA, mas diminuiu mais ainda quando comparados com o Sealapex, MTA e RSA. O amálgama e os implantes de titânio não mostraram significante diminuição de proteínas. Houve baixa secreção de $\mathrm{PGE}_{2}$ dos fibroblastos gengivais quando em contato com o MTA e implantes de titânio; reações similares também ocorreram na cultura de fibroblastos nasais, sendo o tumor de células epiteliais o menos sensível. Os autores concluíram que é possível 
obter evidências de reações celulares por novos e antigos materiais dentários.

MORETTON et al. ${ }^{110}$ (2000) compararam a biocompatibilidade e o potencial osteocondutivo e osteoindutivo do MTA e do cimento EBA, após implantes subcutâneos e intraósseos em ratos. A reação tecidual foi avaliada aos 15, 30 e 60 dias após os implantes. Os implantes subcutâneos de MTA induziram, inicialmente, reações severas como necrose por coagulação, calcificação distrófica e áreas de fibrose. $O$ infiltrado inflamatório era constituído de macrófagos, linfócitos e células plasmáticas, estando presentes, também, células gigantes tipo corpo estranho. Com o tempo, a reação tornou-se moderada. Já os implantes de cimento EBA induziram, inicialmente, a reações moderadas com infiltrado predominantemente composto por linfócitos e alguns macrófagos. Com o decorrer do tempo, o material foi encapsulado por tecido conjuntivo fibroso e a inflamação foi predominantemente suave. Osteogênese não foi observada com nenhum dos materiais nos implantes subcutâneos, indicando que os materiais não foram osteoindutores. As reações teciduais aos implantes intraósseos, para ambos os materiais, foram menos intensas do que para os implantes subcutâneos. Ocorreu osteogênese associada à esses implantes, indicando que ambos os materiais são osteocondutores. Os dois materiais foram considerados biocompatíveis. O EBA foi considerado de nível 2, isto é, materiais como guta-percha e óxido de zinco, que provocam uma resposta inicial de leve a moderada, que diminui com o tempo. Já o MTA, foi considerado de nível 3 , assim como o hidróxido de cálcio, ou seja, o material induz uma resposta inflamatória inicial de moderada a severa, incluindo respostas teciduais como formação de células gigantes do tipo corpo estranho, necrose coagulativa e calcificações distróficas e essa resposta diminui com o tempo.

\section{FARACO JÚNIOR; HOLLAND ${ }^{50}$ (2001) analisaram} histomorfologicamente a resposta da polpa de dentes de cães submetida ao 
capeamento com MTA e cimento de hidróxido de cálcio (Dycal). Foram utilizados três cães, com oito meses de idade. Após anestesia e isolamento absoluto do campo operatório, realizou-se exposições pulpares com 0,5mm de diâmetro na face vestibular dos dentes. A hemorragia foi controlada com irrigações de água estéril e mechas de algodão autoclavadas. As polpas expostas foram protegidas com os materiais a serem testados, sendo os dentes selados com cimento de óxido de zinco e eugenol. Cada grupo experimental teve 15 dentes tratados. Após 2 meses, os animais foram mortos e as peças preparadas para análise microscópica. Os cortes teciduais foram seriados, com $6 \mu \mathrm{m}$ de espessura, e corados por H.E. e Brown \& Breen. Os critérios analisados foram quanto a ponte de tecido mineralizado (continuidade, aspectos morfológicos, espessura, localização), reação inflamatória (crônica ou aguda, número de células e extensão da reação), presença de células gigantes, partículas de material capeador e microrganismos. Os resultados mostraram que em todos os espécimes capeados com MTA foram observadas pontes de tecido mineralizado do tipo tubular, sendo que em 8 espécimes foi observada uma pequena quantidade de tecido necrótico na porção superficial das pontes, e em muitos casos, esta se apresentava com pequenas irregularidades e morfologia distinta. Não foram observados infiltrado inflamatório e microrganismos nos espécimes tratados com MTA. Já com o Dycal, foram constatadas pontes de tecido mineralizado em somente 5 casos, sem inflamação e sem zona de necrose superficial. Em 12 dos 15 espécimes do grupo do hidróxido de cálcio apresentaram processo inflamatório crônico, onde em 11 casos foram observadas partículas do material dispersas no tecido e no citoplasma de macrófagos. Bactérias gram-positivas foram encontradas na polpa coronária de 4 espécimes desse grupo. Os autores concluem que o MTA é superior ao cimento de hidróxido de cálcio como capeador pulpar, e isto se deve a sua capacidade seladora, biocompatibilidade, alcalinidade e outras propriedades associadas com esse material. 
Em 2001, THOMSON et al. ${ }^{152,153}$ investigaram a capacidade de cementoblastos sofrerem diferenciação quando em contato com o MTA por meio da marcação de proteínas específicas para a mineralização. O MTA foi preparado em condições assépticas e mantido incubado a $5 \% \mathrm{CO}_{2}$ e a $37^{\circ} \mathrm{C}$ para presa final por $24 \mathrm{~h}$. Em seguida foi colocado em contato com os cementoblastos e novamente incubado por 7 e 12 dias. Para detectar a expressão de osteocalcina utilizou-se um microscópio confocal e anticorpos policlonais específicos para essa proteína. Os resultados mostraram que em ambos os períodos houve a formação de osteocalcina. Os autores concluíram que o MTA apresenta a capacidade de produzir matriz mineralizada pelos cementoblastos.

O processo de reparo de perfurações radiculares laterais intencionais após selamento com MTA foi avaliado por HOLLAND et al. ${ }^{74}$ em 2001. Quarenta e oito canais radiculares de dentes de cães foram instrumentados e obturados com cimento e cones de guta-percha. A seguir, foi realizada a remoção parcial da obturação e uma perfuração intencional com broca na área lateral da raiz. As perfurações foram, então, seladas com MTA ou cimento Sealapex (grupo controle). A análise microscópica foi efetuada 30 e 180 dias após o tratamento. Os resultados mostraram ausência de inflamação e deposição de cemento sobre o MTA, na maioria dos espécimes. No período de 180 dias, o grupo do Sealapex exibiu inflamação crônica em todos os espécimes e pequena deposição de cemento sobre o material, em somente 3 casos. Concluíram, que o MTA apresentou melhores resultados que o grupo controle.

HOLLAND et al. ${ }^{78}$, em 2002, investigaram a reação do tecido conjuntivo subcutâneo de ratos frente à implantação de tubos de dentina preenchidos com MTA branco (ProRoot). Os animais foram sacrificados após 7 e 30 dias. As peças não descalcificadas foram preparadas para análise microscópica. Cortes teciduais de $10 \mu \mathrm{m}$ foram realizados empregando-se um micrótomo de tecido duro, que depois foram analisados 
com luz polarizada e técnica de Von Kossa para tecidos mineralizados. Os resultados observados foram os mesmos nos dois períodos experimentais, apresentando numerosas granulações birrefringentes à luz polarizada e uma estrutura irregular semelhante a uma ponte foi observada próximo ao material, ambos Von Kossa positivo. Os resultados foram similares aos reportados para o MTA cinza, indicando que o mecanismo de ação do MTA branco e cinza são similares.

TZIAFAS et al. ${ }^{172}$ (2002) realizaram um estudo para verificar o efeito dentinogênico do MTA após capeamento pulpar. Realizaram exposições pulpares em cavidades classe $V$ de 33 dentes de 3 cães, entre 12 e 18 meses de idade, e sobre as polpas expostas aplicaram uma camada de MTA pressionando-a levemente com uma bolinha de algodão umedecida. As cavidades foram então restauradas com amálgama. As respostas pulpares de 21 dentes foram avaliadas por meio de microscopia eletrônica de transmissão (TEM) e de 6 dentes por microscopia eletrônica de varredura (SEM) após intervalos de 1, 2 e 3 semanas. Decorrido o período de uma semana, os autores observaram uma zona homogênea de estrutura cristalina iniciando sua formação ao longo da interface MTA/polpa, ao mesmo tempo em que células pulpares com mudanças em seu estado citológico e funcional estavam depositadas próximas aos cristais. Após duas semanas, deposição de um tecido mineralizado de forma osteóide foi observado em todos os dentes em contato íntimo com o material capeador e com estruturas cristalinas. Depois de três semanas uma barreira de tecido mineralizado obliterando todo tecido pulpar foi observado. De acordo com os autores, essa camada era formada por uma camada irregular de osteodentina e uma matriz de dentina composta por células alongadas, identificadas através de microscopia eletrônica de varredura como estrutura de dentina reparadora. Os autores concluíram que o MTA é um material capeador efetivo, capaz de estimular a formação de dentina reparadora através do mecanismo de defesa da polpa. 
HOLLAND et al. $^{77}$ (2002) estudaram a reação do tecido conjuntivo subcutâneo de 70 ratos após implantação de tubos de dentina contendo os seguintes cimentos endodônticos: MTA, Sealapex, CRCS, Sealer 26 e Sealer Plus. Tubos de dentina foram preparados a partir de raízes de dentes humanos, irrigados com EDTA e hipoclorito de sódio, lavados em água destilada e autoclavados. Dez animais foram utilizados como grupo controle. Os tubos preenchidos com os cimentos foram implantados na região dorsal dos animais, os quais foram mortos após 7 e 30 dias. Os tubos juntamente com os tecidos adjacentes foram removidos e fixados em solução de formalina a 10\% e pH 7,0. Em seguida, sem realizar a descalcificação, os espécimes foram inseridos em uma mistura de parafina e cera de carnaúba e seccionados em micrótomo para tecido duro, para possibilitar análise microscópica. Alguns cortes foram descalcificados por 10 minutos, em EDTA, antes de serem corados com H.E.. Nos animais do grupo controle, nos quais não se utilizaram cimentos nos tubos, observou-se após sete dias ligeira inflamação tecidual, porém, aos 30 dias tornou-se uma cápsula fibrosa com poucas células inflamatórias. O MTA e o Sealapex em contato com o tecido, provocaram granulações mais numerosas do que os outros materiais, e o MTA formou uma estrutura mais extensa, no teste de Von-Kossa. Resultados semelhantes foram observados em todos os materiais estudados, exceto quando utilizados tubos com CRCS, os quais não apresentaram nenhum tipo de estrutura mineralizada sugerindo que este material poderia ter uma menor possibilidade de estimular a deposição de tecido mineralizado.

ANTUNES et al. ${ }^{8}$, em 2002, avaliaram in vitro a citotoxicidade do MTA e Super EBA, em cultura de fibroblastos embrionários da linhagem $\mathrm{NIH}-3 \mathrm{~T} 3$, cultivados inicialmente com $1 \times 10^{4}$ células. Após a confluência, os materiais, previamente manipulados, foram adicionados em lamínulas. A observação da sobrevivência celular, quando em contato com os materiais em teste, em períodos de 1, 3, 5 e 7 dias, permitiu concluir que os grupos do MTA e Super-EBA não demonstraram diferença estatística entre si na 
diminuição do número de células viáveis ao longo do tempo decorrido, quando comparadas às do grupo controle. Houve, no entanto, crescimento celular até o final do experimento, com a presença dos materiais, o que indica que os dois produtos utilizados apresentam o mesmo grau de toxicidade. Assim, os dois materiais podem ser considerados biocompatíveis em experimentos de toxicidade, em cultura celular de fibroblastos embrionários.

REGAN; GUTMANN; WITHERSPOON ${ }^{126}$, em 2002, avaliaram o potencial do MTA e Diaket em promover a regeneração tecidual perirradicular quando utilizados como materiais retrobturadores. Foram utilizados sete cães, que depois de anestesiados tiveram os canais radiculares dos pré-molares inferiores limpos, modelados e obturados. A abertura coronária foi selada com IRM. Na mesma sessão foram feitas cirurgias parendodônticas nos mesmos dentes, e cavidades retrógradas foram realizadas com ultra-som com aproximadamente 1,0 a $1,5 \mathrm{~mm}$ de diâmetro e 1,5 a 2,0 de comprimento, que foram seladas com MTA ou Diaket. Sessenta dias após a cirurgia, os animais foram mortos, e as peças contendo os dentes removidas e preparadas para análise microscópica. Cortes teciduais de $6 \mu \mathrm{m}$ de espessura foram corados por H.E. e pelo Tricômico de Masson e examinados no microscópio de luz. As avaliações foram feitas por 2 examinadores, calibrados, que davam escores, com critério pré-estabelecido. Os resultados mostraram que não houve diferença estatística entre os materiais quanto à presença de inflamação e formação de abscesso. Houve grande quantidade de formação óssea associada aos materiais, como também a formação de novo ligamento periodontal. A presença de cemento foi variável, houve excelentes casos, onde o ápice radicular e os materiais retrobturadores foram completamente cobertos. Os autores concluíram que tanto o Diaket quanto o MTA podem auxiliar na completa regeneração do periodonto perirradicular quando utilizados como materiais retrobturadores em dentes desinfetados. 
ECONOMIDES et al. ${ }^{45}$ (2003) investigaram a resposta dos tecidos perirradiculares ao MTA num curto espaço de tempo. Foram utilizados no experimento 24 canais radiculares de 2 cães saudáveis. Os animais foram anestesiados e procedeu-se a pulpectomia, sendo os canais obturados com guta-percha e cimento. Na mesma sessão foram realizadas cirurgias parendodônticas e o MTA e o IRM utilizados nas obturações retrógradas dos canais. Esse procedimento foi realizado nos cães por hemiarcadas, em períodos de tempo diferentes: 1, 2, 3 e 5 semanas. Após os períodos experimentais os animais foram mortos e as peças preparadas para análise microscópica. Os cortes teciduais de $7 \mu \mathrm{m}$ de espessura foram corados por H.E. e avaliados em microscópio de luz, sendo que dois canais selados com MTA por 2 e 3 semanas foram analisados em microscópio eletrônico de varredura. Os resultados mostraram que para o grupo do MTA a reação tecidual mais marcante após 1 semana foi a presença de tecido conjuntivo frouxo. Inflamação foi observada ocasionalmente, e com o decorrer do tempo, sinais de reparação tecidual foram vistos, caracterizados por formação de tecido mineralizado, que cresceu progressivamente da periferia das paredes da raiz e junto à interface MTA/tecido mole. Em contraste, no grupo do IRM foi observada inflamação, de moderada a severa, em seis de oito raízes e não foi observada formação de tecido mineralizado. Os autores concluíram que o MTA é um material biocompatível que estimula o reparo do tecido perirradicular quando utilizado em retrobturações, entretanto a natureza do novo tecido formado necessita de futura elucidação.

DUARTE et al. ${ }^{42}$, em 2003, avaliaram o pH e a liberação de íons de cálcio do ProRoot MTA e MTA-Angelus após 3, 24, 72 e 168 horas. Utilizaram 5 tubos de plástico, preenchidos com cada material e os colocaram em recipientes de plástico contendo água destilada. Os resultados mostraram que os valores de $\mathrm{pH}$ e da liberação de íons de cálcio foram significativamente mais altos no MTA-Angelus do que o ProRoot MTA. A liberação de íons de cálcio e o pH em ambos os materiais inicialmente 
foram altos. Os dois materiais liberam cálcio e promovem o $\mathrm{pH}$ alcalino com valores altos, durante o período inicial.

AEINEHCHI et al. ${ }^{5}$, em 2003, compararam o agregado de trióxido mineral (ProRoot) como o hidróxido de cálcio (Dycal) quando usados como capeadores pulpares em dentes de humanos. Foram utilizados onze pares de terceiros molares superiores de pessoas entre 20 e 25 anos de idade, os quais tinham indicação para extração. Os dentes foram abertos mecanicamente e a polpa exposta foi recoberta com ProRoot ou Dycal, e o selamento das aberturas feito com ZOE e amálgama. Ao total 14 dentes foram extraídos, nos seguinte períodos: após uma semana (2 molares), dois meses ( 3 molares), três meses (5 molares), quatro meses (2 molares) e seis meses (2 molares). Os ápices dos dentes foram seccionados imediatamente após as extrações para penetração da solução fixadora, e deixados nesta por uma semana. Passado este período as peças foram descalcificadas em ácido fórmico $10 \%$ de 2 a 3 semanas e então preparadas para análise microscópica. Seis cortes de $100 \mu \mathrm{m}$ foram realizados no sentido vestíbulopalatino em cada peça, e corados por H.E.. A análise microscópica consistiu em observar a severidade, tipo e localização da inflamação, presença de necrose, hiperemia e calcificações em áreas fora da ponte de dentina e camada odontoblástica. A espessura da ponte dentinária foi medida empregando-se um software de computador (Adobe Photoshop 6). Os resultados mostraram menor inflamação, hiperemia e necrose, como também maior espessura da ponte de dentina e maior freqüência de formação da camada odontoblástica com o ProRoot do que com o Dycal. Os autores concluíram que o MTA (ProRoot) é superior ao hidróxido de cálcio (Dycal) quando utilizados como capeador de polpas de dentes humanos, e que futuras pesquisas com maior número de amostras e maior tempo de controle devem ser realizados.

HAGLUND et al. ${ }^{62}$, em 2003, investigaram o efeito do MTA, IRM, amálgama e Retroplast no crescimento, morfologia celular e na produção de 
citocinas IL-1 $1 \beta$ e IL-6 em fibroblastos e macrófagos de ratos. Colocaram os materiais recentemente misturados e após a presa, em cultura de células de fibroblastos (L929) e macrófagos (RAW 264.7). Após 3 dias de incubação a $37^{\circ} \mathrm{C}$, a morfologia celular foi examinada e realizada a contagem de células. Para a produção de citocinas foi utilizado o ensaio de ELISA, após incubação, por 24 horas, dos macrófagos, com os materiais em teste. Todos os materiais inibiram o crescimento das células e morfologicamente o MTA foi caracterizado com proteínas desnaturadas e células mortas adjacentes ao material, fato apenas observado no grupo de MTA recentemente misturado. Não houve nenhuma produção de citocinas (IL-1ß e IL-6) em nenhum dos materiais testados.

ASRARI; LOBNER ${ }^{11}$ (2003) investigaram in vitro o mecanismo de neurotoxicidade dos materiais de obturação retrógrada. Foram utilizadas culturas de neurônios e os seguintes materiais: MTA, amálgama, Super-EBA e Diaket. Pelo contato dos materiais com os neurônios, haveria a liberação da enzima lactato desidrogenase que pode ser quantificada. Os resultados mostraram que com exceção do MTA, todos os outros materiais foram citotóxicos. O amálgama, Super-EBA e Diaket promoveram considerável morte celular de neurônios após a sua exposição por 24 horas. Os autores consideraram que o zinco, contido tanto no amálgama, como nos cimentos Super-EBA e Diaket seja o principal responsável pela citotoxicidade. Concluíram que apesar do zinco apresentar-se como uma substância conhecida pela sua característica neurotóxica, não deve merecer maior interesse, pois o organismo controla sistematicamente os níveis de zinco no corpo.

A biocompatibilidade e 0 efeito mitogênico de materiais empregados para obturação retrógrada quando em contato com culturas de células osteoblásticas, odontoblásticas e células tronco da polpa dentária humana foram avaliadas por SHIN et al. ${ }^{138}$, em 2003. Foram utilizados o IRM, Super-EBA, ProRoot ${ }^{\mathrm{TM}}$ cinza e branco, Geristore ${ }^{\circledR}$ e Retroplast ${ }^{\mathrm{TM}}$. 
Culturas de células crescida em placas sem os materiais serviram de controle. A fixação e morfologia das células foram examinadas por meio de um microscópio eletrônico de varredura e a proliferação celular avaliada pelo teste MTT. Os resultados mostraram que após 6 horas em contato com os materiais, as células foram atraídas por eles, com exceção do Retroplast. Tanto o MTA cinza como o branco apresentaram efeito mitogênico sobre células osteogênicas e odontogênicas. Já o Geristore não apresentou qualquer tipo de estímulo para a proliferação celular. Os autores concluíram que o MTA e o Geristore são biocompatíveis, porém o MTA mostrou ser superior aos demais materiais avaliados por apresentar maior efeito mitogênico sobre as células osteogênicas e odontogênicas.

O poder antimicrobiano do MTA quando associado a clorhexidina foi estudado por SUBRAMANIAN et al. ${ }^{150}$, em 2003. Os autores utilizaram o ProRoot ${ }^{\circledR}$ com água destilada, ProRoot ${ }^{\circledR}$ com clorexidina a $0,12 \%$ e somente clorexidina em E. faecalis inoculados em placas com ágar $\mathrm{BH}$ (Brain-Heart-Infusion). Após a colocação dos materiais e o período de incubação foi possível mensurar as zonas de inibição. Os resultados mostraram que a mistura da clorexidina com 0 ProRoot ${ }^{\circledR}$ foi significantemente melhor do que o ProRoot ${ }^{\circledR}$ com água destilada. Porém, a clorexidina isoladamente promoveu halos de inibição maiores do que a mistura ProRoot ${ }^{\circledR}+$ clorexidina. Os autores concluíram que outros estudos devem ser realizados para se constatar se as demais propriedades já conhecidas do ProRoot ${ }^{\circledR}$ não podem ser alteradas pela associação com a clorexidina.

O comportamento de células do osteossarcoma MG-63 e de odontoblastos primários foi analisado quando em contato com o ProRoot MTA e o MTA White por PÉREZ et al. ${ }^{120}$, em 2003. O comportamento foi comparado pela fixação e pela ação osteogênica de ambas linhagens de células. As células permaneceram expostas por 6, 9 e 13 dias aos materiais, depois foram preparadas para exame no microscópio eletrônico de 
varredura, onde se pode observar que o número de células na superfície da placa de cultura, e sobre os materiais, aumentaram em todas as partes das amostras, nos três períodos de tempo, com exceção para o MTA White, onde não foram encontrados osteoblastos primários sobre o material até o fim do $13^{\circ}$ dia. Ambos tipos de células também foram cultivadas e expostas ao $\beta$-fosfatoglicerídeo e à dexametasona para avaliar a formação de nódulos de mineralização em conseqüência de sua ação osteogênica, onde nódulos médios foram observados nas culturas dos osteoblastos primários, mas não foram encontrados nas culturas das células do osteossarcoma MG-63. Os autores concluíram que os osteoblastos primários não permaneceram fixados na superfície do MTA White por um longo tempo em cultura, e que os osteoblastos primários são mais sensíveis do que as células do osteossarcoma MG-63 para o MTA White em culturas de células, sendo estas células mais apropriadas para testes de materiais endodônticos in vitro.

ASRARI; LOBNER ${ }^{12}$, em 2003, estudaram o efeito neurotóxico dos cimentos comumente utilizados em obturações retrógradas. Os materiais testados foram o MTA, amálgama, Super-EBA e Diaket. Os materiais foram colocados em contato com culturas de neurônios recémmanipulados e após a presa final aos sete dias. A morte dos neurônios foi quantificada utilizando o método Assay, pela liberação da enzima citolítica lactato desidrogenase (LDH). Os resultados mostraram que após $24 \mathrm{~h}$ de contato dos neurônios com o MTA não houve significante morte celular. Já com o amálgama, Super-EBA e Diaket houve significante morte celular. Os mesmos resultados repetiram-se quando do contato dos neurônios com os materiais após a presa final aos sete dias.

PEREIRA et al. ${ }^{119}$, em 2003, compararam a capacidade de selamento, em perfurações radiculares, do Sealer 26 , Sealapex + óxido de zinco e eugenol, ProRoot MTA, Cimento Portland em dentina seca, bem como MTA-Angelus e Cimento Portland em dentina úmida. Utilizaram 60 
dentes caninos humanos, nos quais a perfuração foi realizada no terço médio da superfície externa da raiz para a luz do canal radicular (no local de maior espessura dentinária). A perfuração foi realizada inicialmente com uma ponta diamantada esférica número 1016, em alta rotação e, em seguida, completada por uma broca esférica número 8 , em baixa rotação, até atingir o canal radicular. As raízes foram impermeabilizadas e preenchidas com cimento de óxido de zinco e eugenol, com auxílio de uma espiral de Lentulo e então subdivididas em seis grupos experimentais, com 10 raízes cada. A perfuração foi preenchida com o material em teste e imediatamente as raízes foram imersas em solução de azul de metileno a $2 \%$, em temperatura ambiente, sem vácuo, por 72 horas. O ProRoot MTA, MTA Angelus e o Cimento Portland, em ambiente seco ou úmido, apresentaram maior infiltração de corante em relação ao Sealer 26 e ao Sealapex. Os cimentos Sealer 26 e o Sealapex mostraram melhores resultados que os demais grupos. Os autores afirmam que é pertinente a elaboração de estudos complementares no campo físico, químico e biológico desses materiais, como alternativa de tratamento das perfurações radiculares.

FRIDLAND; ROSADO ${ }^{56}$, em 2003, avaliaram a solubilidade e a porosidade do MTA em diferentes proporções de água. No estudo, determinaram a composição química dos sais dissolvidos no MTA. Utilizaram quatro proporções de água $(0,26,0,28,0,30$ e 0,33 g) por $1 \mathrm{~g}$ de cimento para cada 6 amostras, sendo a última a proporção recomendada pelo fabricante. Para a determinação do grau de porosidade e solubilidade, aumentava-se a proporção de água no pó do MTA. Os resultados mostraram diferença estatisticamente significante e as misturas se comportaram mais solúveis e porosas quando tinham maior quantidade de água. A análise química dos sais dissolvidos no MTA identificou a presença de cálcio como seu maior componente (482 mg/lt). Essa capacidade de liberar cálcio pode ser significante para a clínica, porque dá ao MTA capacidade para induzir a mineralização. 
DIAMANTI et al. ${ }^{39}$, em 2003, analisaram e compararam a composição química, $\mathrm{pH}$ e as características da superfície do MTA cinza com o MTA branco (ProRoot MTA). Os resultados da composição química pela difração de raios X mostraram que o MTA cinza e o branco têm muita similaridade com os cimentos Portland comuns, porém com diferenças entre os dois materiais. O óxido de ferro $\left(\mathrm{Fe}_{2} \mathrm{O}_{3}\right)$ esteve ausente no MTA branco e o sulfato de cálcio $\left(\mathrm{CaSO}_{4}\right)$ ausente no MTA cinza. Após a mensuração com o pHmetro, o MTA branco apresentou um pH alto (11,32 - 11,38), imediatamente após o preparo e também durante o período de observação de 2 horas. Ambos os materiais, MTA cinza e branco, tiveram uma considerável superfície rugosa $\left(R_{a}=1,94 \mu m\right.$ vs $R_{a}=1,90 \mu m$, respectivamente). Concluíram que o MTA cinza e branco (ProRoot MTA) são cimento Portland com alto $\mathrm{pH}$ e de superfície rugosa quando tomam presa.

Em 2004, FERRIS; BAUMGARTNER ${ }^{52}$ avaliaram a capacidade de selamento em perfurações de furca de dois tipos de MTA, em molares superiores e inferiores humanos extraídos, usando o modelo experimental para infiltração de bactérias anaeróbicas. Foram selecionados 40 dentes, aleatoriamente, que tiveram suas coroas removidas e $5 \mathrm{~mm}$ no terço apical. As perfurações foram realizadas no centro do assoalho, em alta rotação, com broca número 330 e ampliadas com lima calibre 80 , passando $5 \mathrm{~mm}$ além da superfície radicular. Logo após, os dentes foram divididos em dois grupos experimentais, com 18 cada, deixando 2 dentes para controle positivo e 2 para o grupo controle negativo. Os dois tipos de MTA utilizados foram: grupo I - MTA cinza (fórmula original) e grupo II - MTA branco (novo material). Os dentes foram montados em matrizes, para mantê-los a $37^{\circ} \mathrm{e}$ com $100 \%$ de umidade e o meio de cultura utilizado foi especificamente para - Fusobacterium nucleatum. Uma vez selados, os dentes foram armazenados em câmara anaerobiótica a $37^{\circ} \mathrm{C}$ e observados diariamente. As avaliações da infiltração bacteriana chegaram a 60 dias e os resultados mostraram que duas das 18 amostras seladas com MTA cinza e três das seladas com MTA branco filtraram, mas não houve diferença 
estatisticamente significante entre os dois tipos de MTA na prevenção da infiltração do Fusobacterium nucleatum, quando utilizado como selamento de perfurações de furca.

A reação do tecido conjuntivo subcutâneo frente ao MTA (Dentsply) e ao amálgama (Oralloy- Coltene) foi avaliada por YALTIRIK et al. ${ }^{182} \mathrm{em}$ 2004. Esses materiais foram colocados em tubos de polietileno e implantados no tecido conjuntivo dorsal de ratos albinos Wistar. As biópsias dos tecidos foram coletadas e analisadas histologicamente após $7,15,30$, 60 e 90 dias da implantação. Foram avaliadas a presença de inflamação, tipo de célula predominante, calcificação e a espessura do tecido conjuntivo fibroso. Os escores foram definidos como: 0 , nenhuma ou poucas células inflamatórias, sem reação; $1,<25$ células, discreta reação; 2, 25 a 125 células, reação moderada; $3, \geq 125$ células, reação severa. A cápsula fibrosa foi categorizada com "fina" quando a espessura era $<150 \mu m$ e "densa" quando $>150 \mu \mathrm{m}$. A necrose e formação de calcificação também foram avaliadas. No período de 90 dias os resultados mostraram que ambos materiais foram bem tolerados pelos tecidos. Um achado notável foi a presença de calcificações distróficas no tecido conjuntivo adjacente ao MTA. Os autores concluem que este achado é consistente com as hipóteses de indução da formação de tecido mineralizado pelo MTA.

\subsection{Da comparação do MTA com o cimento Portland}

A origem e composição química do MTA sempre despertaram a curiosidade daqueles que se interessavam pelo material, e estas informações eram omitidas nos trabalhos experimentais e nas bulas originais.

Essa inovação começou a ser esclarecida em 1999, quando WUCHERPFENNIG; GREEN ${ }^{180}$ publicaram um abstract chamando a atenção ao afirmar que o MTA tinha características e propriedades 
semelhantes ao cimento Portland, disponível para a construção civil. Segundo os autores, ambos são constituídos principalmente por cálcio, fosfato e sílica. Os dois materiais foram idênticos na análise macroscópica, microscópica e pela difração de raios $X$ e quando misturados com água, endurecem, sendo levados a uma fase sólida. Observaram ainda a biocompatibilidade do MTA e cimento Portland em cultura de células osteoblasto-like (MG-63). Em 4 e 6 semanas, ambos os materiais permitiram a formação de uma matriz mineralizada de maneira similar. Em um outro trabalho in vivo colocaram o MTA e cimento Portland como capeadores pulpares diretos, após exposição da polpa em ratos adultos. Os animais foram sacrificados após uma, duas, três e quatro semanas e seus dentes, processados histologicamente. Os resultados mostraram um efeito similar sobre as células pulpares e também deposição de dentina reparadora, em alguns casos, nas primeiras duas semanas após os procedimentos. As observações preliminares indicaram que o cimento Portland pode ser um material selador ideal, tanto quanto o MTA.

Um ano depois, ESTRELA et al. ${ }^{48}$ (2000) investigaram a composição química e a capacidade antimicrobiana do MTA, cimento Portland, pasta de $\mathrm{Ca}(\mathrm{OH})_{2}$, Sealapex® e Dycal ${ }^{\circledR}$. Quatro tipos de cepas bacterianas provenientes da ATCC (American Type Culture Collection) foram utilizadas: Staphylococcus aureus, Enterococcus faecalis, Pseudomonas aeroginosa e Bacillus subtilis. Um tipo de fungo também foi empregado neste estudo: a Cândida albicans, proveniente da USP - SP. Inicialmente realizou-se o teste de difusão e inibição em agar. Os resultados mostraram que apenas o $\mathrm{Ca}(\mathrm{OH})_{2}$ promoveu halos de inibição de 6 a 9,5mm. Já os demais cimentos testados, com exceção do Dycal, promoveram apenas halos de difusão. O Dycal não apresentou halos de difusão ou inibição. Em seguida, utilizando-se da espectrofotometria de fluorescência, analisou-se a composição química dos elementos presentes no MTA e em duas amostras do cimento Portland. Os autores concluíram que os elementos químicos presentes no MTA são os mesmos do cimento Portland, com a exceção do 
Bismuto presente somente no MTA, sendo talvez o responsável pela sua radiopacidade. Segundo os autores o cimento Portland é composto de: $\mathrm{CaO}(58,5 \%), \quad \mathrm{SiO}_{2}(17,7 \%), \quad \mathrm{Al}_{2} \mathrm{O}_{3}(4,5 \%), \quad \mathrm{MgO}(3,3 \%), \quad \mathrm{SO}_{3}(3,0 \%)$, $\mathrm{Fe}_{2} \mathrm{O}_{3}(2,9 \%), \mathrm{K}_{2} \mathrm{O}(0,9 \%)$ e $\mathrm{Na}_{2} \mathrm{O}(0,2 \%)$. Apesar da semelhança com o MTA o cimento Portland pode conter impurezas que podem afetar tanto a sua cristalização como provocar algum tipo de reação. Isto depende também de onde foi extraído o mineral. Concluíram finalmente que as semelhanças de composição química entre MTA e cimento Portland justificam os resultados obtidos neste estudo, onde ambos apresentaram praticamente a mesma atividade antimicrobiana.

BERNABÉ; HOLLAND ${ }^{17}$ (2003) salientaram que, recentemente, o fabricante do ProRoot MTA modificou algumas informações contidas no MSDS (Material Safety Data Sheet) original, acrescentando que o material é composto por $75 \%$ de cimento Portland, $20 \%$ de óxido de bismuto e $5 \%$ de sulfato de cálcio di-hidratado. Portanto o próprio fabricante do MTA admitiu a presença do cimento Portland na composição do produto. Assim, o estudo das propriedades do MTA ficou facilitado pelo conhecimento já adquirido, sedimentado e difundido a respeito do cimento da construção civil. Isto motivou os pesquisadores a realizar uma série de trabalhos comparando os dois cimentos.

Os efeitos do MTA e cimento Portland na secreção de $\mathrm{PGE}_{2}$ por monócitos foram avaliados por SAFAVI; NICHOLS ${ }^{129}$, em 2000. Os autores utilizaram monócitos provenientes de sangue fracionado e incubados a $37^{\circ} \mathrm{C}$ e na presença de $5 \% \mathrm{CO}_{2}$ por $2 \mathrm{~h}$. Em seguida procedeu-se nova incubação agora contendo os materiais por $24 \mathrm{~h}$. Os níveis de prostaglandina $\left(\mathrm{PGE}_{2}\right)$ foram mensurados. Foi utilizado como controle positivo o LPS (S. typhimurium). Os resultados mostraram diminuição da produção de $\mathrm{PGE}_{2}$ em contato com os materiais. Os autores concluíram que tanto o MTA como o cimento Portland possuem semelhante efeito inibitório da formação de 
prostaglandina pelos monócitos, e isso se deve à solubilidade de alguns produtos contidos nesses materiais.

HOLLAND et al. $^{75}$, em 2001, analisaram a reação do tecido subcutâneo de ratos frente à implantação de tubos de dentina preenchidos com MTA, cimento Portland ou hidróxido de cálcio. Tubos de dentina com $7 \mathrm{~mm}$ de comprimento e $0,5 \mathrm{~mm}$ de espessura foram preparados de raízes de dentes humanos. Depois de esterilizados foram obturados com os cimentos e implantados na região dorsal de 30 ratos, um de cada lado da linha mediana. Tubos de dentina vazios foram implantados em mais 10 ratos e serviram de controle. Os animais foram mortos após sete e 30 dias e os espécimes, não descalcificados, foram preparados para análise microscópica com luz polarizada e técnica de Von Kossa para tecidos mineralizados, sendo que alguns cortes foram descalcificados por 10 minutos em EDTA e corados por H.E.. Houve inflamação crônica moderada em todos os espécimes tanto aos sete como aos 30 dias. Os resultados foram similares para os 3 materiais estudados. Perto das embocaduras dos tubos foram observadas granulações Von Kossa positivas, birrefringentes à luz polarizada, e junto a elas um tecido irregular na forma de ponte, e também túbulos, formando uma camada em diferentes profundidades. Os autores concluíram que o óxido de cálcio contido no MTA e possivelmente no cimento Portland seja o responsável pela formação destas granulações, reação esta que também ocorre com o $\mathrm{Ca}(\mathrm{OH})_{2}$, levando-os a crer que o mecanismo da indução de tecido mineralizado do MTA e do cimento Portland possivelmente seja o mesmo do $\mathrm{Ca}(\mathrm{OH})_{2}$.

HOLLAND et al. $^{73}$ (2001) realizaram um estudo com o objetivo de analisar o comportamento da polpa dental de cães após pulpotomia e proteção pulpar direta com agregado de trióxido mineral (MTA) ou cimento Portland (PC). Foram utilizados 18 dentes de um cão jovem, totalizando 26 raízes. Após anestesia geral e isolamento absoluto, foi realizada a abertura coronária e remoção da polpa presente na câmara pulpar com curetas. 0 
sangramento foi controlado por meio de irrigação com solução salina esterilizada e por pressão com mechas de algodão esterilizadas. Em seguida, os remanescentes pulpares foram protegidos com MTA ou PC. As aberturas coronárias foram seladas com óxido de zinco eugenol e amálgama. Após 60 dias os animais foram mortos, as peças removidas e preparadas para análise microscópica. Cortes seriados de $6 \mu \mathrm{m}$ foram corados pelas técnicas H.E. e Brown \& Brenn. Avaliou-se a formação de ponte de tecido mineralizado, sob os aspectos de continuidade, morfologia e espessura. A reação inflamatória foi avaliada quanto ao seu quadro (aguda ou crônica), número de células, presença de células gigantes e partículas do material fagocitado, bem como a existência ou não de microorganismos. Essa avaliação foi realizada por escores e os dados foram analisados pelo teste de Kruskal-Wallis. Os resultados obtidos foram semelhantes para os 2 materiais testados, tendo sido observada formação de ponte de dentina tubular em quase todos os casos estudados. Foram observadas partículas dos cimentos no citoplasma de alguns macrófagos. A polpa dentária apresentou reação inflamatória crônica moderada. Não houve diferença estatística significante entre os cimentos analisados. Os autores concluíram que o MTA e o cimento Portland possibilitam a obtenção de resultados semelhantes entre si, quando empregados diretamente sobre a polpa dentária, após realização da pulpotomia.

HOLLAND et al. ${ }^{72}$, em 2001, analisaram o processo de reparo dos tecidos periapicais de dentes de cães após pulpectomia e obturação dos canais com MTA e cimento Portland. Para os estudo, dez pré-molares foram instrumentados pela técnica mista invertida, receberam curativo de demora de uma associação de corticosteróide e antibiótico por 7 dias, e depois obturados com cones de guta-percha mais MTA ou cimento Portland. Noventa dias após a obturação os animais foram mortos e as peças removidas e fixadas em solução de formalina a $10 \%$. Depois foram descalcificadas em ácido fórmico e citrato de sódio e preparadas para análise microscópica. Os cortes seriados foram de $6 \mu \mathrm{m}$ de espessura, e 
corados com H.E.. Os resultados obtidos foram semelhantes para os dois cimentos, houve a formação de barreira biológica completa e ausência de inflamação na maioria dos casos. Os autores concluíram que a reparação dos tecidos periapicais de dentes de cães é semelhante com ambos materiais estudados, quando empregados na obturação de canais radiculares.

SILVA et al. ${ }^{139}$, em 2002, avaliaram o comportamento do cimento ProRoot MTA, em relação ao cimento Portland (Votoram), quanto à estabilidade dimensional e solubilidade/desintegração, com base na especificação número 57 da Associação Dental Americana (ADA). Para a estabilidade dimensional, confeccionaram corpos de prova cilíndricos, com dimensões de $12 \mathrm{~mm}$ de altura por $6 \mathrm{~mm}$ de diâmetro, que, após mensuração de seus comprimentos com um paquímetro digital, foram imersos em $30 \mathrm{ml}$ de água destilada por 30 dias. Para solubilidade/desintegração, os corpos de prova utilizados tinham $1,5 \mathrm{~mm}$ de espessura e $20 \mathrm{~mm}$ de diâmetro, os quais depois de pesados, foram imersos em $50 \mathrm{ml}$ de água destilada por 7 dias. Os resultados para a estabilidade dimensional foram ProRoot MTA $(+0,12)$ e cimento Portland $(+0,95)$ e para solubilidade/desintegração ProRoot MTA $(-7,19)$ e cimento Portland $(-7,76)$. Em relação à estabilidade dimensional, os dois cimentos encontraram-se dentro das normas da ADA e quanto à solubilidade/desintegração, ambos apresentaram valores acima do determinado pela ADA.

GUARIENTI; OSINAGA; FIGUEIREDO ${ }^{61}$, em 2002, analisaram, por meio de microscópio eletrônico de varredura XL-20 (Philips) e sonda EDX (Energy Dispersive X-Ray), a microestrutura superficial e a composição química do MTA e de duas marcas comerciais de cimento Portland. Após manipulação dos cimentos e inserção em moldes, os corpos de prova foram armazenados ao abrigo da luz por 38 dias, quando então foram removidos e submetidos ao exame. Os resultados mostraram que a superfície dos corpos de prova dos cimentos possui a mesma estrutura microscópica, com 
exceção do bismuto. Os principais constituintes do MTA foram encontrados em ambas as marcas de cimento Portland, com pequenas diferenças nas suas quantidades, sendo que nas amostras de cimento Portland se observou molibdênio.

A reação tecidual do MTA (ProRoot®) e cimento Portland quando implantados em tecido ósseo foi investigada por SAIDON et al. ${ }^{131}$, em 2002. Utilizaram 30 porquinhos da Índia que após anestesia e exposição cirúrgica da mandíbula, cavidades bilaterais foram preparadas para implantação de tubos de politetrafluoretileno preenchidos com os materiais recém manipulados. Cada animal recebeu dois implantes, um de MTA (ProRoot ${ }^{\circledR}$ ) e outro de cimento Portland pré-esterilizado em óxido de etileno, perfazendo 56 implantes. Os animais foram mortos após os períodos de 2 e 12 semanas, e a peças, contendo os implantes, removidas e preparadas para análise microscópica. Os resultados mostraram que houve mínima resposta inflamatória tanto para o MTA quanto para o cimento Portland em ambos os períodos experimentais. Os autores concluíram que o MTA e o cimento Portland foram, de forma semelhante, bem tolerados pelo tecido ósseo mandibular de porquinhos da Índia.

DEAL et al. $^{37}$ (2002) compararam as propriedades químicas e físicas do MTA, cimento Portland e de um novo material experimental, o MTA de presa rápida. Foi utilizada espectroscopia de energia dispersa para análise química. O tempo de presa foi avaliado segundo as normas da especificação $n^{\circ} 96$ ANSI/ADA. Os elementos químicos encontrados foram os mesmos para o ProRoot ${ }^{\circledR}$, cimento Portland e MTA de presa rápida, inclusive na presença do bismuto em uma proporção de $20,1 \%$ para o ProRoot ${ }^{\circledR}, 17,3 \%$ para o cimento Portland e 15,5\% para o MTA de presa rápida. Imediatamente após a manipulação $\mathrm{o} \mathrm{pH}$ foi de 11,72 para 0 ProRoot ${ }^{\circledR}, 11,74$ para o cimento Portland e 11,69 para o MTA de presa rápida. O tempo de presa foi de 156 minutos para o ProRoot ${ }^{\circledR}, 159$ minutos para o cimento Portland e 17 minutos para o MTA de presa rápida. Os 
autores concluíram que o MTA de presa rápida apresentou propriedades químicas semelhantes ao ProRoot ${ }^{\circledR}$ e cimento Portland, porém com tempo de presa significantemente mais rápido.

FUNTEAS; WALLACE; FOCHTMAN ${ }^{58}$, em 2002, realizaram uma análise comparativa dos elementos químicos do cimento Portland e do MTA, utilizando um espectrômetro por inductibilidade de plasma acoplado (ICPES). A análise revelou que 14 elementos químicos eram os mesmos para ambos os cimentos, não apresentando significante diferença quantitativa, com exceção do bismuto, que não pode ser quantificado no cimento Portland. Já os demais elementos químicos foram quantificados e mostraram muitas semelhanças entre ProRoot ${ }^{\circledR}$ e cimento Portland.

A possibilidade de contaminação no MTA-Angelus ${ }^{\circledR}$ (cinza e branco), sem estarem esterilizados, e no cimento Portland (Votoran, Votorantim, São Paulo, Brasil), de um saco recém-aberto e de um aberto há dois meses foi avaliada por DUARTE et al. ${ }^{41}$, em 2002. As amostras foram inoculadas assepticamente em $3 \mathrm{ml}$ de caldo $\mathrm{BHI}$ e incubadas a $37^{\circ} \mathrm{C}$ por 24 horas e em $3 \mathrm{ml}$ de caldo de Sabouraud, acrescido de cloranfenicol, e incubadas a $25^{\circ} \mathrm{C}$ por 72 horas. Após incubação, os tubos foram homogeneizados e as amostras plaquetadas em meios específicos para o crescimento de Gram+, Gram-, Staphylococcus, Pseudomonas, Enterococcus e fungos. As placas com meio específico para bactérias foram incubadas a $37^{\circ} \mathrm{C}$ por 24 horas e as com meio específico para fungos foram mantidas a $25^{\circ} \mathrm{C}$ por 15 dias. Diante da metodologia empregada e da análise dos resultados, os autores concluíram que os materiais testados não apresentam contaminação.

ABDULLAH et al. ${ }^{1}$, em 2002, investigaram a biocompatibilidade de duas variantes do cimento Portland com acelerador (CPA) por meio da observação da citomorfologia de células de osteosarcoma (SaOS-2) na presença dos materiais testados e o efeito desses materiais na expressão de 
marcadores da remodelação óssea. Foram utilizados para comparação o cimento de ionômero de vidro (CIV), o MTA, e o cimento Portland (CP) não modificado. Um ensaio de contato direto foi realizado em quatro amostras para cada material teste, coletadas com 12, 24, 48 e 72 horas. A morfologia celular foi registrada utilizando microscopia eletrônica de varredura (SEM). A análise microscópica mostrou células SaOS-2 sadias aderidas às superfícies das variantes do CPA, do CP e MTA. Em contraste, células arredondadas, em processo de morte celular, foram observadas junto ao CIV. O ELISA mostrou níveis significantemente elevados de IL-1 1 , IL-6, IL-18 nas variantes do CPA comparado com os controles e CIV $(p<0.01)$, no entanto esses níveis de citocinas não foram estatisticamente significantes quando comparados com o MTA. Sugeriram que as duas variantes do CPA não são tóxicas e possuem potencial para promover o reparo ósseo, mas estudos futuros sobre o CPA deveriam ser realizados com o intuito de desenvolver um possível material restaurador e para uso ortopédico.

SAIDON et al. ${ }^{138}$, em 2003, compararam o efeito citotóxico in vitro em cultura de células L929 e in vivo a reação do tecido ósseo de cobaias, após implantação de ProRoot MTA e cimento Portland. Para o estudo in vitro, os materiais em teste foram colocados imediatamente após a mistura e a presa. Foram incubados por 3 dias e se observou a morfologia e a contagem das células. Para o estudo in vivo realizaram 2 cavidades ósseas nas mandíbulas de 28 cobaias e implantaram recipientes de teflon preenchidos com os materiais recentemente misturados no interior das cavidades ósseas. Os animais receberam um implante de ProRoot MTA e um de cimento Portland e foram mortos depois de 2 e 12 semanas. Não existiu diferença nas reações celulares in vitro e em períodos experimentais foi observado tecido ósseo saudável e mínima resposta inflamatória adjacente aos implantes de ProRoot MTA e cimento Portland. Como ambos os materiais foram bem tolerados in vitro e in vivo, os autores concluem que o cimento Portland tem o potencial de ser usado como um material de retrobturação mais barato. 
ESPINDOLA et al. ${ }^{47}$, em 2003, avaliaram a qualidade do selamento em perfurações de furca com MTA-Angelus, ProRoot MTA, cimento Portland e Super-EBA, por meio de um modelo bacteriano. Foram utilizados 66 molares humanos inferiores extraídos: 15 para cada grupo e três para os controles positivo e negativo. As perfurações foram realizadas com uma broca número 3 . O modelo bacteriano consistiu em que a furca selada com os materiais ficasse submersa em caldo $\mathrm{BHI}$ estéril. As amostras foram submetidas à saliva humana e incubadas a $37^{\circ} \mathrm{C}$, com observações diárias. Após 52 dias, os resultados mostraram o Super-EBA como o que promoveu o melhor selamento em relação aos outros materiais, seguido do MTA-Angelus e ProRoot, com resultados semelhantes entre si. Finalmente, o cimento Portland apresentou os piores resultados, estatisticamente significantes.

DEUS et al. ${ }^{38}$, em 2003, avaliaram in vitro a citotoxicidade do ProRoot MTA, MTA-Angelus e o cimento Portland, por meio da viabilidade metábolica de cultura de células endoteliais, pelo teste de redução do brometo de dimetiltiazol-difeniltetrazólico. Os materiais foram manipulados e adaptados em cilindros padronizados de $3 \times 2 \mathrm{~mm}$ e colocados nas culturas de células por períodos de 24, 48 e 72 horas. $O$ grupo controle não foi exposto aos cimentos. Os resultados revelaram que tanto os cimentos quanto $o$ tempo de contato com as células influenciaram na viabilidade celular. Após 24 horas, todos os cimentos apresentaram-se mais citotóxicos que as células controle, embora tenha havido diferença significante entre os 3 cimentos testados. Após 48 e 72 horas, a diferença não foi significativa entre o grau de citotoxicidade dos três materiais em teste. Apesar de que os três cimentos apresentaram um alto efeito citotóxico inicial, ele foi decrescendo significantemente com o passar do tempo, possibilitando a recuperação celular. 
CHAKMAKCHI et al. ${ }^{30}$, em 2003, compararam a capacidade de selamento de dois tipos de MTA (cinza e branco) e um tipo comum de cimento Portland, para o tratamento de perfurações de furca. Foram utilizados 34 molares humanos extraídos. As raízes foram cobertas por esmalte de unhas e a perfuração foi realizada no centro do assoalho, com broca esférica número 4. Os dentes foram imersos até a junção amelocementária, em uma esponja umedecida com água destilada e as perfurações, seladas com os materiais em teste. As aberturas coronárias foram seladas com IRM e cobertas pelo esmalte de unhas e os dentes, deixados na esponja umedecida por um mês, e depois foram imersos, por 48 horas, em fucsina básica a $1 \%$. Os espécimes foram analisados pelo microscópio (100X) e os resultados mostraram diferença significante entre os grupos do MTA branco e cimento Portland, mas não houve diferença entre os grupos do MTA branco e MTA cinza. Tanto o MTA branco (ProRoot MTA) como o MTA cinza selaram perfeitamente as perfurações e foram significantemente melhores do que o cimento Portland.

\section{CAMPOS QUINTANA; LLAMOSAS HERNÁNDEZ; MORALES}

DE LA LUZ ${ }^{28}$ (2003) avaliaram a biocompatibilidade do cimento Portland quando implantado no tecido conjuntivo de ratos. Tubos de polietileno de $4 \mathrm{~mm}$ de comprimento, desinfetados em glutaraldeído a $2 \%$ e lavados em soro fisiológico, foram preenchidos com o material e implantados nos ratos. Cada rato recebeu dois implantes, um com cimento Portland e outro vazio, que serviu de controle, colocados um de cada lado da linha mediana, no dorso do animal. Os animais foram mortos 8, 15, 30 e 45 dias após cirurgia, e a seguir as peças contendo o tubo e tecidos adjacentes foram preparadas para análise microscópica. Os cortes teciduais foram obtidos seriadamente, com $6 \mu \mathrm{m}$ de espessura e corados por H.E. e azul de metileno. Os resultados mostraram não haver diferença entre o grupo controle e o grupo experimental, ambos apresentaram infiltrado inflamatório similar, onde aos 8 dias foi notória a presença de polimorfonucleares e expansão da matriz celular, devido ao edema, sendo que aos 15, 30 e 45 dias o infiltrado 
inflamatório caracterizou-se, principalmente, pela presença de macrófagos e células linfóides. Deve-se destacar, nesses períodos, a presença de células sebáceas e eosinófilos que aumentaram em número com o passar do tempo. Segundo os autores, isto parece indicar uma reação do tipo alérgica aos tubos implantados. Concluíram que o cimento Portland não provocou reação adversa à distância no tecido subcutâneo dos ratos; que o tubo de polietileno causou reação alérgica, mas que pode ter sido encoberta pela biocompatibilidade do cimento. Os resultados deste e de outros estudos parecem indicar a utilização do cimento Portland no tratamento de complicações endodônticas. 
3 PROPOSIÇÃO 


\section{PROPOSIÇÃO}

O objetivo deste trabalho foi avaliar e comparar, microscopicamente, a resposta do tecido subcutâneo de ratos frente a implantação de tubos de polietileno contendo os seguintes materiais:

- ProRoot MTA branco contendo óxido de bismuto como radiopacificador,

- MTA Branco (Angelus) contendo sulfato de bário como radiopacificador,

- MTA Branco (Angelus) contendo óxido de bismuto como radiopacificador,

- Cimento Portland branco contendo óxido de bismuto como radiopacificador. 


\section{MATERIAL E MÉTODOS}




\section{MATERIAL E MÉTODOS}

\subsection{MATERIAL}

\subsubsection{ANIMAIS}

Foram utilizados 36 ratos machos da linhagem Wistar (Rattus norvegicus), adultos jovens, com peso entre 200 e 300 gramas, provenientes do Biotério da Faculdade de Odontologia de Bauru - USP, mantidos em gaiolas plásticas coletivas, higienizadas, colocadas em ambiente arejado e iluminado naturalmente, recebendo água ad libitum e alimentação constituída de ração comercial balanceada. Previamente ao início do experimento, o projeto de pesquisa foi submetido à apreciação do Comitê de Ética no Ensino e Pesquisa em Animais (CEEPA - Protocolo $n^{\circ} 35 / 2003$ ) e aprovado em 05/11/2003.

\subsubsection{CIMENTOS}

Foram utilizados quatro cimentos, sendo dois da mesma marca comercial, com a seguinte composição e proporção:

\section{ProRoot MTA branco ${ }^{1}$ (Figura 1)}

Apresentação : 5 envelopes com $1 \mathrm{~g}$ cada de MTA.

5 ampolas com $0,7 \mathrm{~g}$ cada de água destilada.

\footnotetext{
${ }^{1}$ Dentsply - Tulsa Dental, Tulsa OK, USA.
} 
Composição do Pó:

O cimento Portland é o principal componente, correspondendo a $75 \%$ do peso.

$3 \mathrm{CaO}-\mathrm{SiO}_{2}-$ Silicato tricálcico

$2 \mathrm{CaO}-\mathrm{SiO}_{2}-$ Silicato dicálcico

$3 \mathrm{CaO}-\mathrm{Al}_{2} \mathrm{O}_{3}-$ Aluminato tricálcico

$4 \mathrm{CaO}-\mathrm{Al}_{2} \mathrm{O}_{3}-\mathrm{Fe}_{2} \mathrm{O}_{3}-$ Aluminoferrato tetracálcico

Contém ainda :

$\mathrm{Bi}_{2} \mathrm{O}_{3}$ - Óxido de bismuto, aproximadamente $20 \%$ do peso total.

$\mathrm{CaSO}_{4}-2 \mathrm{H}_{2} \mathrm{O}$ - Sulfato de cálcio diidratado (gesso), aproximadamente $5 \%$ do peso total.

Proporção:

A proporção utilizada nos experimentos foi a recomendada pelo fabricante ${ }^{124}$, uma parte de pó para uma de líquido. Após a mistura obtevese um cimento arenoso e úmido.

O tempo de presa inicial, segundo o fabricante, é de 2 horas e 45 minutos e o final é de aproximadamente 4 horas.

2. MTA Branco com óxido de bismuto ${ }^{2}$

3. MTA Branco com sulfato de bário²

${ }^{2}$ Angelus Soluções Odontológicas - Londrina, Paraná, Brasil. 
O MTA Branco é um novo produto da Indústria Angelus Odontológicas, localizada na cidade de Londrina, Paraná, Brasil. Quando recebemos o material, em junho de 2003, ainda não havia sido comercializado, e duas amostras para ensaio foram testadas (Figura 2), apresentando diferentes radiopacificadores na composição, um já utilizado na versão cinza, o óxido de bismuto, e outro usado na composição das resinas compostas, o sulfato de bário. Em janeiro de 2004 o MTA Branco com óxido de bismuto foi lançado no mercado, e a bula do material mostra a mesma composição do pó e mesma proporção de uso da versão anterior (cinza).

Apresentação : 1 vidro contendo $1 \mathrm{~g}$ de pó

1 frasco contendo água destilada

Composição pó :

$\mathrm{SiO}_{2}$ - Dióxido de silício

$\mathrm{K}_{2} \mathrm{O}$ - Óxido de potássio

$\mathrm{Al}_{2} \mathrm{O}_{3}$ - Alumina

$\mathrm{Na}_{2} \mathrm{O}$ - Óxido de sódio

$\mathrm{Fe}_{2} \mathrm{O}_{3}$ - Óxido férrico

$\mathrm{SO}_{3}$ - Trióxido de enxofre

$\mathrm{CaO}$ - Óxido de cálcio

$\mathrm{Bi}_{2} \mathrm{O}_{3}$ - Óxido de bismuto

$\mathrm{MgO}$ - Óxido de magnésio

Contém ainda, resíduos insolúveis de:

- Sílica cristalina

- Óxido de cálcio

- Sulfato de potássio e sódio 
A proporção pó/líquido utilizada nos experimentos foi a mesma recomendada pelo fabricante ${ }^{112}$, sendo, uma medida de pó para uma gota de água destilada. Após a mistura, obtinha-se um cimento arenoso e úmido. Segundo o fabricante, em contato com a água forma um gel coloidal que se solidifica formando uma estrutura rígida no intervalo de 15 minutos.

\section{Cimento Portland branco ${ }^{3}$ (Irajazinho)}

Para obtenção do cimento Portland, a matéria-prima (calcário e argila) é extraída e levada para moer, onde se reduz o tamanho das pedras, depois é misturada intimamente a outros componentes em proporções adequadas (pré-homogeneização), e submetida a altas temperaturas em grandes fornos com temperatura de aproximadamente $1450^{\circ} \mathrm{C}$. Nessa temperatura, o material sofre fusão incipiente formando pelotas, chamadas de clínquer (foto da capa), que depois de resfriado é moído até um pó bem fino com a adição de gesso, então, ele é armazenado e vendido a granel.

O cimento Portland possui vários constituintes, mas os principais são: silicato tricálcico $\left(3 \mathrm{CaO}-\mathrm{SiO}_{2}\right)$, silicato dicálcico $\left(2 \mathrm{CaO}-\mathrm{SiO}_{2}\right)$, aluminato tricálcico $\left(3 \mathrm{CaO}-\mathrm{Al}_{2} \mathrm{O}_{3}\right)$, ferroaluminato tetracálcico $\left(4 \mathrm{CaO}-\mathrm{Al}_{2} \mathrm{O}_{3}-\mathrm{Fe}_{2} \mathrm{O}_{3}\right)$, sulfato de cálcio diidratado $\left(\mathrm{CaO} . \mathrm{SO}_{3} .2 \mathrm{H}_{2} \mathrm{O}\right)$, óxidos alcalinos e outros constituintes. O cimento Portland branco (Figura 3) é produzido pela pulverização de um clínquer de cimento Portland branco. A cor cinza do clínquer do cimento Portland comum é devido à presença de ferro e manganês. Portanto, diminuindo-se o teor de ferro do clínquer pode-se produzir cimentos de cores claras. Quando a quantidade total de ferro no clínquer corresponde a menos de 0,5\% de $\mathrm{Fe}_{2} \mathrm{O}_{3}$, e o ferro é mantido no estado reduzido de $\mathrm{Fe}_{2}$, o clínquer geralmente é branco. Estas condições são alcançadas na fabricação do cimento usando-se argila e rochas carbonadas sem ferro como matéria-prima, e tomando-se cuidados especiais, tais como moagem e resfriamento do produto.

\footnotetext{
${ }^{3}$ Votorantim Cimentos, São Paulo, SP, Brasil.
} 
O cimento Portland branco é classificado em dois subtipos: cimento Portland branco estrutural e não estrutural. O primeiro é usualmente aplicado em concretos brancos para fins arquitetônicos, possuindo classes de resistência, similares às dos outros cimentos. Já o cimento Portland não estrutural não tem indicação de classe e é aplicado, por exemplo, no rejuntamento de azulejos e na fabricação de ladrilhos, isto é, em aplicações não estruturais.

O cimento Portland branco não estrutural foi utilizado neste trabalho, e a ele adicionamos $20 \%$ do seu peso total de óxido de bismuto, pois para ser utilizado na clínica endodôntica a radiopacidade é requisito. A proporção foi obtida a partir de uma balança analítica de precisão ${ }^{4}$.

O cimento Portland branco não foi previamente esterilizado, pois não apresenta contaminação, segundo as observações feitas por DUARTE et al. $^{41}$ (2002), e foi manipulado utilizando-se uma medida de pó (medidor MTA-Angelus) para uma gota de água destilada.

\subsubsection{TUBOS DE POLIETILENO}

Foram utilizados 144 tubos de polietileno ${ }^{5}$ com $1,5 \mathrm{~mm}$ de diâmetro interno, 2,0mm de diâmetro externo e 10,0 mm de comprimento (Figura 4), fechados em uma das extremidades por guta-percha, sendo desinfetados em solução de glutaraldeído a $2,2 \%{ }^{6}$, onde foram mantidos por 12 horas. Antes de serem preenchidos com os cimentos, os tubos foram lavados copiosamente em soro fisiológico e secos externamente com gaze estéril e internamente com cones de papel absorvente ${ }^{7}$.

\footnotetext{
${ }^{4}$ GEHAKA - modelo AND-GR-202 - Tokyo, Japão.

${ }^{5}$ Abbott Lab. do Brasil Ltda. - São Paulo, SP.

${ }^{6}$ Cidex - Johnson\&Johnson, Produtos Profissionais Ltda., São José dos Campos, SP.

${ }^{7}$ Tanari - Tanariman Industrial Ltda..
} 


\subsubsection{ANESTESIA DOS ANIMAIS}

Os animais foram pré-anestesiados com cloridrato de ketamina ${ }^{8}$, que é um anestésico, na dose de $25 \mathrm{mg} / \mathrm{Kg}$ IM na face posterior da coxa. Após um período de latência de 2 a 5 minutos, a anestesia foi complementada com a associação do cloridrato de ketamina com cloridrato de xilazina ${ }^{8}$, relaxante muscular, analgésico e sedativo, na dose de $25 \mathrm{mg} / \mathrm{Kg}$ para $10 \mathrm{mg} / \mathrm{Kg} \mathrm{IM}$, respectivamente. O tempo de trabalho para cada animal foi de aproximadamente 40 minutos.

A conduta anestésica seguiu a tabela peso/dosagem estabelecida pelo Biotério da FOB-USP (Anexo 1).

\subsubsection{GRUPOS EXPERIMENTAIS}

Os 36 ratos foram distribuídos em três grupos de 12 animais para cada período experimental, de 15, 30 e 60 dias (Tabela 1). Cada animal recebeu quatro implantes, um de cada tipo de material. O lado selado com a guta-percha serviu como controle.

Tabela 1 - Distribuição dos implantes em relação aos materiais e períodos empregados no experimento.

\begin{tabular}{|c|c|c|c|c|}
\hline \multirow{2}{*}{ GRUPO } & \multirow{2}{*}{ MATERIAL } & \multicolumn{3}{|c|}{ PERÍODO } \\
\hline & & 15 dias & 30 dias & 60 dias \\
\hline 1 & $\begin{array}{l}\text { ProRoot MTA cl } \\
\text { óxido de bismuto }\end{array}$ & 12 & 12 & 12 \\
\hline II & $\begin{array}{l}\text { MTA Branco c/ } \\
\text { sulfato de bário }\end{array}$ & 12 & 12 & 12 \\
\hline III & $\begin{array}{l}\text { MTA Branco c/ } \\
\text { óxido de bismuto }\end{array}$ & 12 & 12 & 12 \\
\hline IV & $\begin{array}{l}\text { cimento Portland branco cl } \\
\text { óxido de bismuto }\end{array}$ & 12 & 12 & 12 \\
\hline $\mathrm{V}$ & Guta-percha (controle) & 48 & 48 & 48 \\
\hline
\end{tabular}

\footnotetext{
${ }^{8}$ Agribrands do Brasil Ltda., Paulínia, SP.
} 
FIGURA 1 - ProRoot MTA, embalagem contendo 5 envelopes com 1 grama de pó cada e recipientes plásticos com água destilada esterilizada.
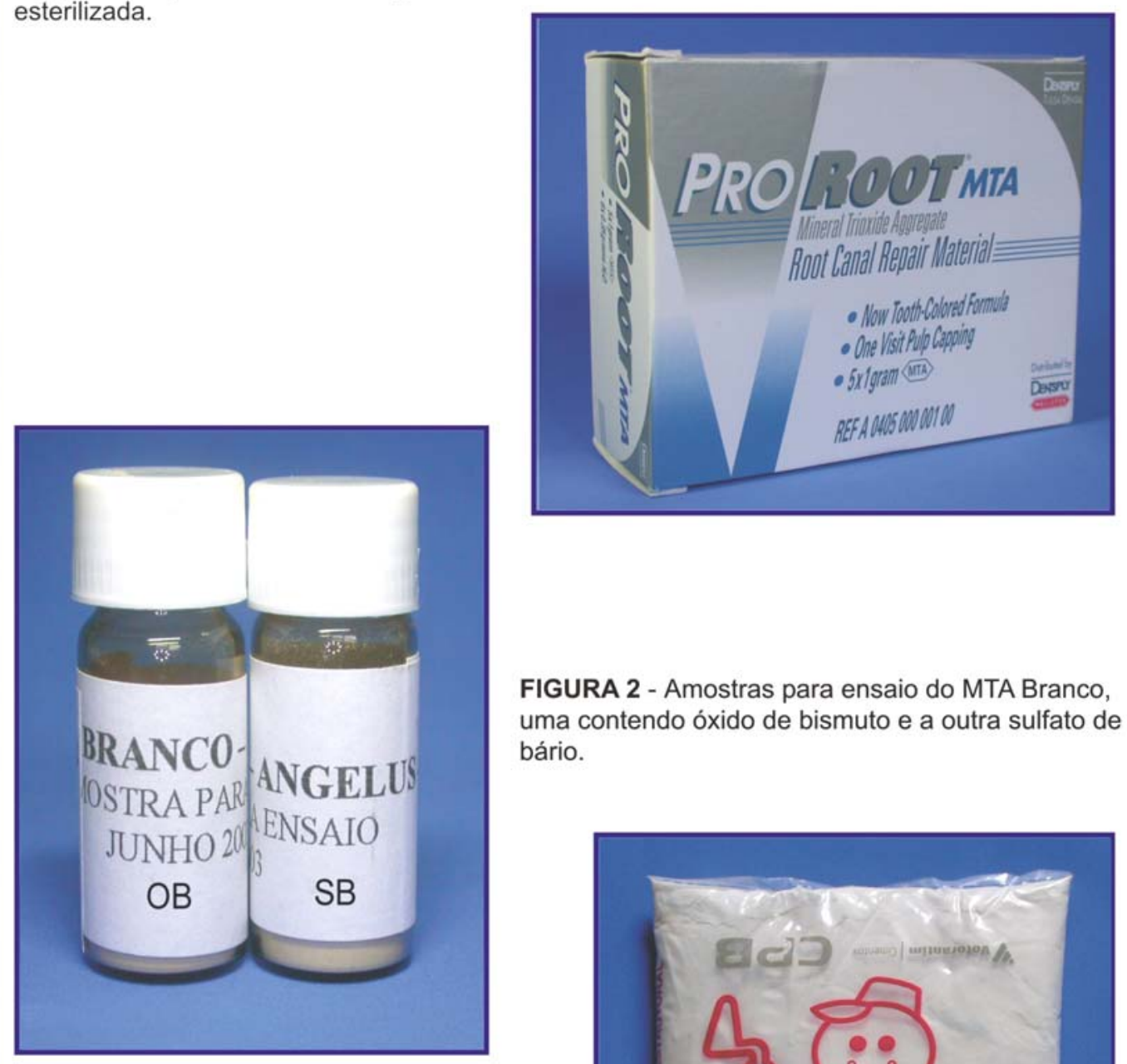

FIGURA 2 - Amostras para ensaio do MTA Branco, uma contendo óxido de bismuto e a outra sulfato de bário.

FIGURA 3 - Embalagem de $1 \mathrm{Kg}$ do cimento Portland branco.

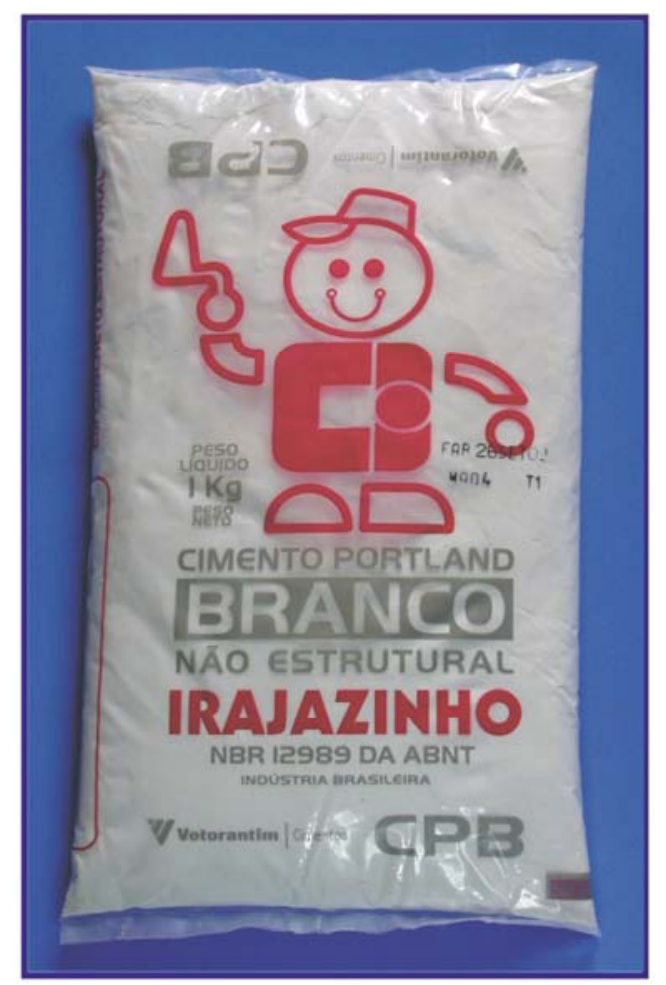




\subsection{MÉTODOS}

Após a pesagem e anestesia, foi realizada a tricotomia da região dorsal dos animais e procedeu-se a anti-sepsia com álcool iodado a $1 \%{ }^{9}$.

Os cimentos foram manipulados e introduzidos no interior dos tubos de polietileno com auxílio de uma espátula de inserção e um calcador endodôntico ${ }^{10}$.

Foram realizadas duas incisões longitudinais na região mediana dorso de cada animal, uma anterior e outra posterior, com lâmina de bisturi $n^{\circ} 15^{11}$. Lateralmente às incisões o tecido cutâneo foi pinçado e uma pequena divulsão foi realizada com tesoura de ponta romba. Em seguida, cada tubo de polietileno, preenchido com um dos cimentos, foi colocado dentro da ponta de um Trocarte (Figura 5), que foi levado até atingir uma profundidade de $18 \mathrm{~mm}$, completando a divulsão dos tecidos (Figura 6). Cuidado extremo foi tomado para não perfurar ou dilacerar os tecidos. Assim obtiveram-se quatro lojas cirúrgicas, uma para cada lado das incisões. Tomou-se o cuidado de realizar os implantes não paralelos à linha de incisão, no sentido de evitar-se a sua expulsão ou mobilidade.

Portanto, cada rato recebeu quatro corpos de prova, dois na região escapular e dois na região pélvica (Figura 7) contendo, cada um, um cimento diferente, obedecendo uma ordem de colocação previamente estabelecida, anotada numa ficha apropriada, havendo rotatividade dos cimentos em relação às regiões anatômicas. As bordas da incisão foram suturadas com fio de seda $4.0^{12}$, que foram removidos após três dias da cirurgia. Para distinguir os ratos, foram feitas marcações com tinta nos rabos.

\footnotetext{
${ }^{9}$ Cinord Sul - Indústria e comércio Ltda., Ribeirão Preto, SP.

${ }^{10}$ Maillefer, Ballaigues, Suíça.

${ }^{11}$ Eletromed - Comércio de Materiais Médicos Cirúrgicos, Manaus, Amazônia, Brasil.

${ }^{12}$ Ethicon - Johnson\&Johnson, Produtos Profissionais Ltda., São José dos Campos, SP.
} 

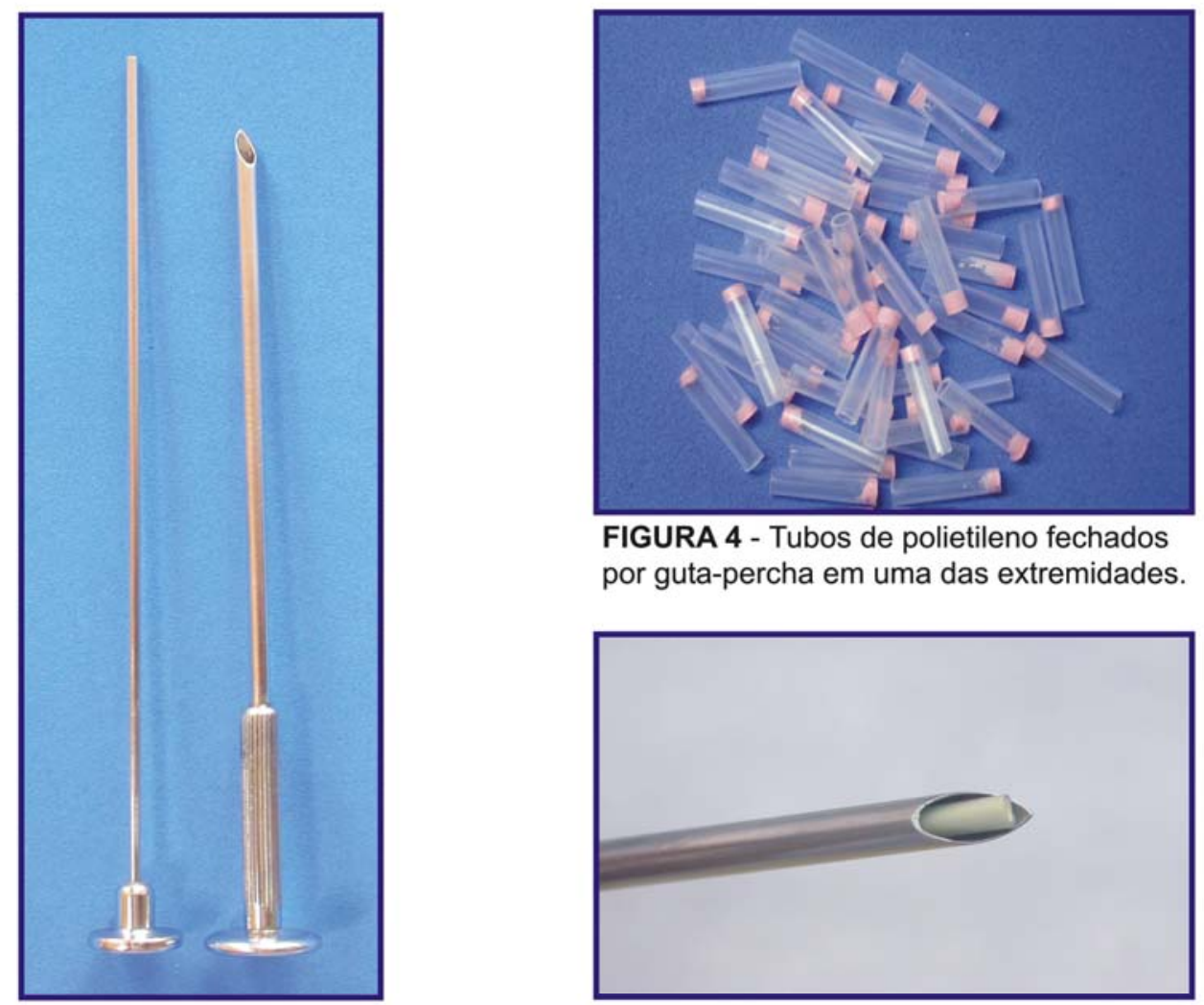

FIGURA 4 - Tubos de polietileno fechados por guta-percha em uma das extremidades.

FIGURA 5 - Trocarte: instrumento que foi utilizado para conduzir os tubos de polietileno. O lado do tubo com cimento ficou voltado para área do tecido menos traumatizada pelo ato cirúrgico (maior aumento).

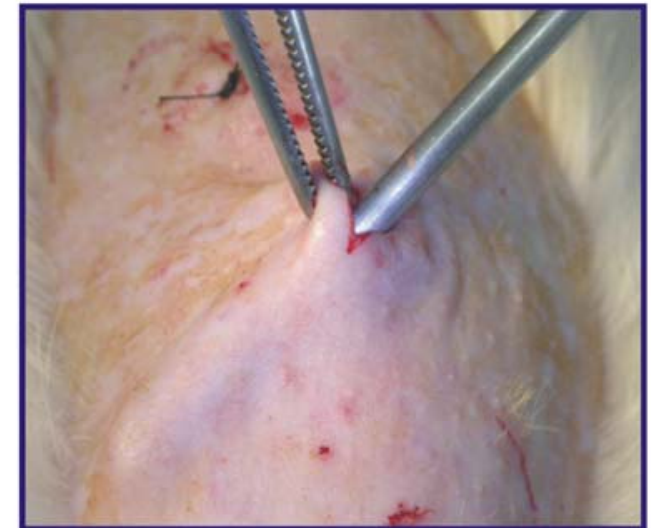

FIGURA 6 - Trocarte introduzido entre o tecido cutâneo e o tecido muscular, onde foi depositado o tubo de polietileno preenchido com o cimento.

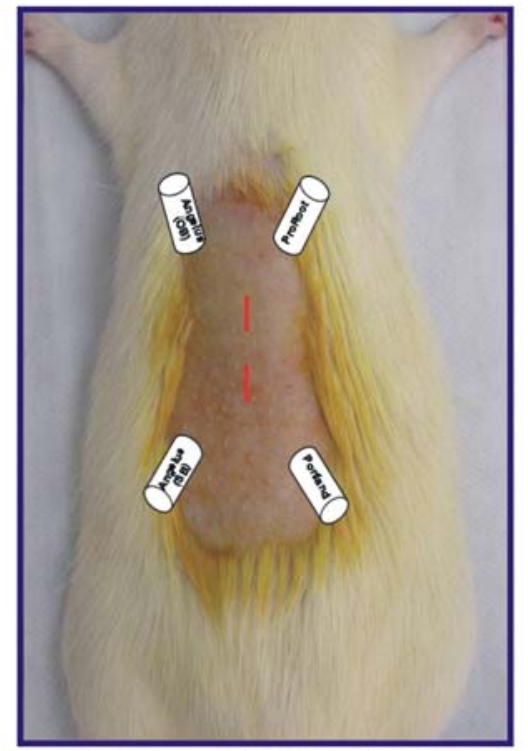

FIGURA 7 - Localização das incisões e distribuição dos tubos de polietileno implantados no dorso dos animais. 
Depois da implantação, os animais foram colocados em gaiolas individuais e acompanhados até que se recuperassem da anestesia, sendo observados diariamente para verificação do comportamento com a finalidade de evitar ocorrências que pudessem comprometer o experimento. Passados sete dias os animais foram novamente colocados em gaiolas coletivas, onde permaneceram até que se completassem os períodos de observação $(15,30$ e 60 dias).

\subsubsection{MORTE DOS ANIMAIS E REMOÇÃO DOS TECIDOS}

Decorridos os períodos experimentais os animais foram anestesiados novamente, e depilados em sua região dorsal que também foi limpa com gazes úmidas. A seguir, foram mortos individualmente com uma dose excessiva de cloridrato de ketamina ${ }^{8}$ (anestésico) injetada no coração. Logo em seguida, os corpos de prova foram localizados por palpação, e a área de implante dissecada, abrangendo suficiente tecido normal circunjacente (Figura 8). Os blocos contendo os tubos e tecidos adjacentes, foram distendidos em papel cartão e fixados em solução de formol a $10 \%$ tamponado, em frascos unitários, com identificação do rato, grupo e localização do tubo (região anterior ou posterior).

\subsubsection{PROCESSAMENTO LABORATORIAL}

Duas semanas após a remoção, os tecidos foram preparados para iniciar a fase laboratorial.

Realizaram-se cortes macroscópicos, onde foi retirado o excesso de tecido. O formato das peças ficou retangular, localizando-se ao centro o tubo de polietileno e ao redor tecido suficiente para análise microscópica (Figura 9). A seguir, as peças foram colocadas em água destilada por uma hora, com o propósito de diminuir a concentração de formol e lavagem. Passado esse período os tubos de polietileno foram removidos. Para remoção utilizou-se uma pinça clínica para apreender o tubo, e com uma 
lâmina de bisturi $n^{\circ} 11$ montada no cabo $n^{\circ} 3$ incisava-se longitudinal e lateralmente o tecido que englobava o tubo de polietileno (Figura 10). Extremo cuidado foi tomado nesta etapa, pois a incisão deve ser firme e única evitando a dilaceração do tecido, como também o corte demasiado, principalmente na embocadura do tubo, região de interesse da investigação. Após incisão, com o auxílio de uma sonda interproximal $n^{\circ} 1$, desprendia-se $o$ tecido em volta do tubo, com especial atenção às extremidades, depois colocava-se a sonda por baixo do tubo puxando-o para fora (Figura 11). Neste momento era observado para que lado estava a guta-percha e o cimento, e assim foi adotado um corte na ponta do retângulo (formato da peça) indicando o lado controle, que também serviu como referência no momento da inclusão. As peças foram então acondicionadas em cassetes unitários com devida identificação.

Para desidratação e diafanização dos tecidos, foi utilizado o histotécnico ${ }^{13}$, um processador automático de tecidos, para posteriormente, as peças serem incluídas manualmente em parafina.

Antes da inclusão tomou-se o cuidado de abrir a parte central da cápsula, que envolvia anteriormente o tubo, possuindo sua forma, e mergulhar novamente a peça em parafina líquida para que o espaço vazio fosse preenchido (Figura 12). Em seguida a inclusão foi realizada, ficando o lado controle anteriormente marcado, virado para o lado da identificação do bloco.

Depois da obtenção dos blocos de parafina, empregou-se um micrótomo ${ }^{14}$ para realização de cortes microscópicos semi-seriados de 5 micrometros, feitos no sentido longitudinal, de modo que as duas extremidades pudessem ser observadas na mesma lâmina. Cada peça foi cortada até que se chegasse próximo da metade do espaço deixado pelo tubo, e então foram colhidos os três cortes mais representativos, observados em um microscópio óptico, assim eliminava-se a agressão causada ao tecido quando da remoção do tubo de polietileno.

\footnotetext{
${ }^{13}$ Leica TP 1010, Reichert \& Jung Products, Alemanha.

${ }^{14}$ RM 2045 - Aotel Instrumentos Científicos Ltda, São Paulo, SP.
} 


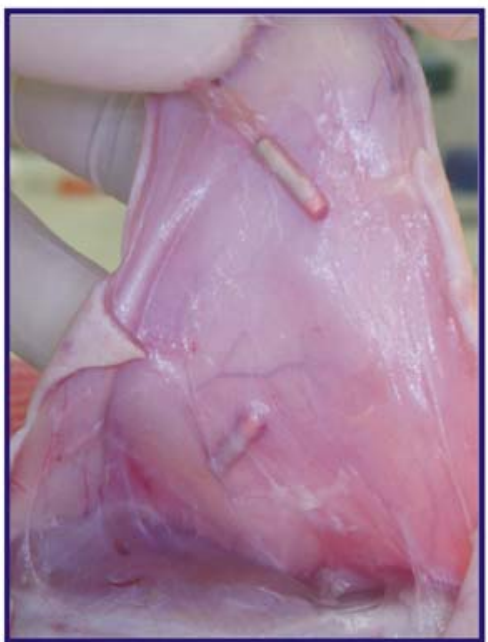

FIGURA 8 - Remoção do tecido circunjacente aos tubos de polietileno.

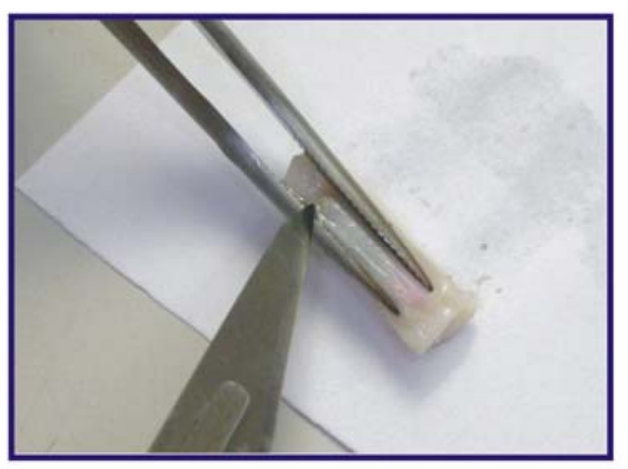

FIGURA 11 - Remoção do tubo após descolamento do tecido. Neste momento o lado controle foi identificado, para posterior marcação.

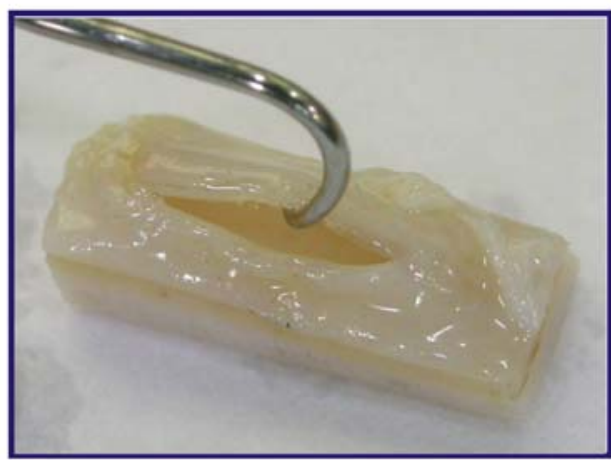

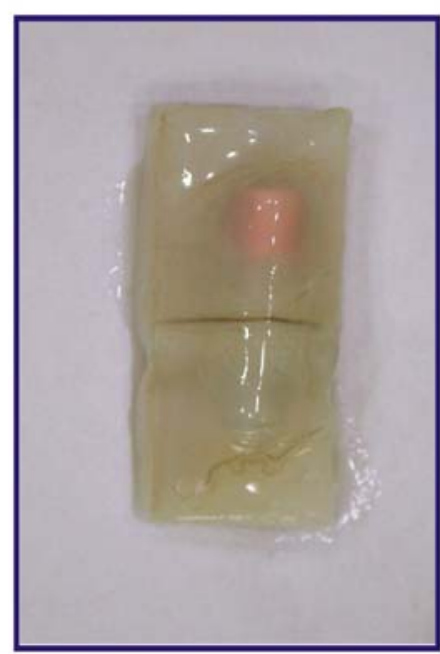

FIGURA 9 - Peça após o corte macroscópico.

FIGURA 10 - Apreensão do tubo com a pinça clínica e incisão lateral e longitudinal do tecido sobre o tubo para a sua remoção.

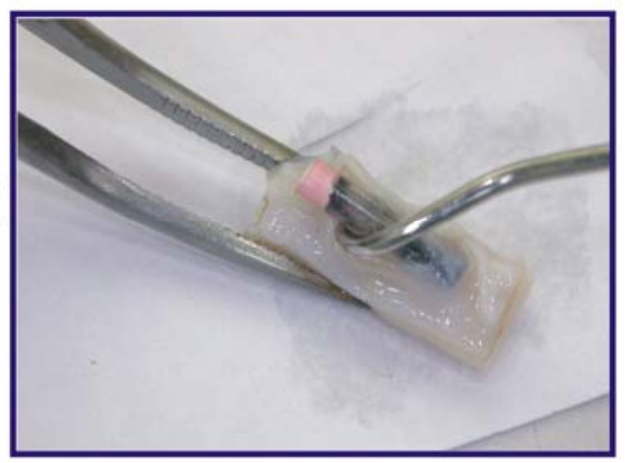

FIGURA 12 - Peça sem o tubo de polietileno após passagem pelo histotécnico. A cápsula foi aberta para ser mergulhada novamente na parafina liquida. 
Os cortes foram corados com hematoxilina e eosina e avaliados por microscopia óptica, para análise da resposta tecidual aos materiais.

\subsubsection{ANÁLISE MICROSCÓPICA}

A avaliação das respostas do tecido conjuntivo em contato com os cimentos testados foi realizada de forma descritiva, quantitativa subjetiva, levando-se em consideração o infiltrado inflamatório e fenômenos correlatos, fenômenos reparatórios e as características dos materiais remanescentes.

Todos os dados relativos às análises microscópicas foram registrados em uma ficha previamente preparada para cada material e períodos analisados.

A leitura das lâminas foi realizada com o auxílio de um microscópio (5x e 40x), por dois observadores, que não tinham conhecimento da ordem dos materiais analisados, em duas ocasiões diferentes.

As lâminas representativas de cada grupo experimental foram fotomicrografadas em aparelho Zeiss, utilizando-se filme Elite Gold-Kodak, ASA 100.

\subsubsection{INFILTRADO INFLAMATÓRIO E REAÇÕES CORRELATAS}

Procurou-se observar a magnitude do infiltrado, tipos celulares presentes, predominantes e sua distribuição em relação aos materiais. Observaram-se também as alterações destrutivas como abscedação e intensidade de alterações vasculares, principalmente o edema e a hiperemia.

Foi realizada uma análise descritiva dos macrófagos e células gigantes multinucleadas inflamatórias (CGMIs), levando-se em consideração os aspectos morfológicos, e utilizando-se os seguintes parâmetros: 
a) distribuição das células em relação ao material;

b) contorno e uniformidade do citoplasma, se homogêneo, vacuolado ou carregado de partículas;

c) aspectos dos núcleos celulares. Número e distribuição dos núcleos das CGMIs.

Os dados foram registrados em fichas e mensurados subjetivamente quanto à sua magnitude utilizando os seguintes escores:

a) Magnitude geral (escores)

$$
\begin{aligned}
& \text { Ausente }=0 \\
& \text { Discreto }=1 \\
& \text { Moderado }=2 \\
& \text { Intenso }=3
\end{aligned}
$$

\subsubsection{FENÔMENOS REPARATÓRIOS E REAÇÕES CORRELATAS}

Analisaram-se as proliferações fibroblásticas e angioblásticas, fibrosamento e a presença de calcificações.

Com relação ao fibrosamento, observou-se sua densidade e organização. A organização foi analisada levando-se em consideração se a sua disposição era ao acaso ou em forma capsular.

Detectada a presença de tecido mineralizado, seria considerada sua localização, se em contato direto com o material próximo ao tubo ou se havia a interposição de um tecido entre ambos.

Os dados da análise descritiva receberam escores que estão demonstrados a seguir: 
a)Proliferação fibroblástica (escores)

$\begin{array}{ll}\text { Ausente } & 0 \\ \text { Discreta } & 1 \\ \text { Moderada } & 2 \\ \text { Intensa } & 3\end{array}$

b)Proliferação angioblástica (escores)

$\begin{array}{ll}\text { Ausente } & 0 \\ \text { Discreta } & 1 \\ \text { Moderada } & 2 \\ \text { Intensa } & 3\end{array}$

c) Fibrosamento - densidade (escores)

$\begin{array}{ll}\text { Ausente } & 0 \\ \text { Discreto } & 1 \\ \text { Moderado } & 2 \\ \text { Intenso } & 3\end{array}$

\subsubsection{CARACTERÍSTICAS DOS CIMENTOS REMANESCENTES}

Foram descritas as características morfológicas dos materiais, se homogêneo, granular, cristalizado, fibroso ou mesmo se estava presente mais de uma destas formas.

Analisou-se a presença ou não de material no interior de macrófagos, a fim de detectar sua capacidade de ser reabsorvível.

Também se levou em conta a localização do material em relação ao tubo de polietileno, se aquém, no nível do tubo ou extruído no tecido conjuntivo.

Estas características foram anotadas em fichas e a partir das verificações observadas, fez-se a análise descritiva de cada material em cada um dos períodos de observação. 


\subsubsection{ANÁLISE ESTATÍSTICA}

A análise de variância para dados (ANOVA) utilizada foi o modelo não paramétrico de Kruskal-Wallis (XAVIER et al. ${ }^{181}$, 1974), sendo considerado o nível de significância de $5 \% \quad(p<0,05)$, fazendo-se comparações entre os quatro cimentos e grupo controle nos três períodos experimentais. Quando constatada diferença estatística significante, foi utilizado o teste de Dunn para comparações individuais. O comportamento de cada material em relação ao tempo também foi analisado. Foi ainda utilizado o índice Kappa (LANDS e $\mathbf{K O C H}^{93}$, 1977) para analisar a confiabilidade das leituras realizadas pelos dois observadores (Tabela 2).

Tabela 2 - Critérios de classificação dos níveis de concordância de coeficiente Kappa.

\begin{tabular}{cc}
\hline Coeficiente Kappa & Nível de concordância \\
\hline$<0,00$ & - \\
$0,00-0,20$ & Baixo \\
$0,21-0,40$ & Médio \\
$0,41-0,60$ & Moderado \\
$0,61-0,80$ & Substancial \\
$0,81-1,00$ & Quase perfeito \\
\hline
\end{tabular}

Embora o coeficiente de concordância Kappa mostrasse concordância "substancial" ou "quase perfeita" em dez dos 12 testes avaliados, em duas avaliações o nível de concordância foi "médio" e "baixo" (Tabela 3). Por este motivo decidiu-se por uma nova calibragem dos observadores, para então, examinar as lâminas onde não houve concordância. Esta segunda análise realizada pelos observadores foi em conjunto, tentando chegar a um consenso. Assim o resultado final da análise foi consistente, não apresentando resultados contraditórios. 
Tabela 3 - Coeficiente de concordância (Kappa) para os fenômenos inflamatório e reparatório nos três períodos analisados.

\begin{tabular}{|c|c|c|c|}
\hline $\begin{array}{l}\text { Fenômenos } \\
\text { analisados }\end{array}$ & 15 dias & 30 dias & 60 dias \\
\hline Intensidade & 0,758389 & 0,933774 & 0,928825 \\
\hline inflamatória & substancial & quase perfeita & quase perfeita \\
\hline Proliferação & 0,831775 & 0,724770 & 0,720670 \\
\hline fibroblástica & quase perfeita & substancial & substancial \\
\hline Proliferação & 0,362397 & 0,663157 & 0,764705 \\
\hline angioblástica & médio & substancial & substancial \\
\hline Densidade do & 0,206611 & 0,802469 & 0,707317 \\
\hline fibrosamento & baixo & substancial & substancial \\
\hline
\end{tabular}


5 RESULTADOS 


\section{RESULTADOS}

O número de componentes da amostra, representativa de cada grupo experimental, não foi o mesmo inicialmente proposto, porque houve perda de alguns espécimes por falha na histotécnica ou por causa da influência de pêlos localizados nas proximidades dos tubos, que foram possivelmente introduzidos no momento da implantação, prejudicando a análise microscópica. Foram acrescentados quatro ratos (reserva) no período de 60 dias, dos quais, alguns fizeram parte da amostragem. A quantidade de espécimes perdidos encontra-se registrada nos quadros de avaliação de cada material e período (Anexos 2, 3, 4, 5, 6, 7, 8, 9, 10, 11, 12, 13 e 14).

O dados obtidos após as análises microscópicas dos espécimes dos cinco grupos, nos três períodos experimentais, são descritos da seguinte forma:

- Material testado

- Análise microscópica descritiva do infiltrado inflamatório, dos fenômenos reparatórios e reações correlatas, para cada cimento nos três períodos experimentais.

- Análise estatística da intensidade inflamatória, proliferação fibroblástica, proliferação angioblástica e densidade do fibrosamento, caracterizados por escores dados aos materiais, nos três períodos experimentais. Realizou-se também análise estatística para o comportamento de cada material nos três períodos experimentais. 


\subsection{ProRoot-MTA (Dentsply) - Grupo I}

\subsubsection{Análise microscópica descritiva do infiltrado inflamatório dos fenômenos reparatórios e reações correlatas no período de 15 dias.}

Os dados referentes a este grupo experimental encontram-se no quadro 1 (Anexo 2).

Nesse material, observou-se a formação de granulomas típicos, e nas áreas onde não havia granulomas, observaram-se macrófagos dispersos, os quais interagiam intensa e diretamente com o material, fagocitando-o com bastante densidade. Essas células estavam distribuídas na periferia e próximos ao material, possuíam tamanho normal e geralmente seus citoplasmas estavam carregados de partículas do mesmo, embora em um caso observou-se um citoplasma com aspecto vacuolar. Os núcleos dessas células apresentaram-se normais e com forma regular.

Em todos os espécimes, observou-se a formação de células gigantes multinucleadas inflamatórias (CGMIs). Essas células estavam distribuídas próximas e na periferia do material; continham em média de três a cinco núcleos, e com os citoplasmas geralmente carregados de partículas do material. As CGMIs apresentavam contorno citoplasmático irregular, e núcleos distribuídos ao acaso, característico de uma reação do tipo corpo estranho.

O processo inflamatório foi considerado de intensidade moderada (média=1,77), com infiltrado composto, principalmente por macrófagos, e em menor número, os linfócitos. Os polimorfonucleares (neutrófilos e eosinófilos), como também os plasmócitos foram visto ocasionalmente.

Quanto aos fenômenos reparatórios, observou-se moderada proliferação fibroblástica (média=1,88) e angioblástica (média=1,55). O fibrosamento apresentou densidade também moderada $(1,66)$, e com organização capsular.

O material apresentou-se de forma granular microscopicamente e se localizou, em todos os espécimes, no nível da abertura do tubo. 
Não foi observada a presença ou imagem sugestiva de formação de tecido mineralizado, seja periférico ou à distância.

\subsubsection{Análise microscópica descritiva do infiltrado inflamatório dos fenômenos reparatórios e reações correlatas no período de $\mathbf{3 0}$ dias.}

Os dados referentes a este grupo experimental encontram-se no quadro 2 (Anexo 3).

Os resultados microscópicos observados nesse período mostravamse semelhantes aos observados aos 15 dias, com predominância dos macrófagos dispostos na periferia do material, e também à distância. Algumas dessas células apresentavam citoplasma homogêneo, mas a maioria carregada de partículas do material.

As CGMIs, tiveram presença constante, distribuídas próximas e na periferia do material; continham em média sete núcleos, ora mais e ora menos; e com os citoplasmas carregados de partículas do material. $O$ contorno citoplasmático mostrou-se irregular em 100\% dessas células. Os núcleos estavam distribuídos ao acaso, característico de uma reação do tipo corpo estranho.

Na proximidade do material pode-se freqüentemente notar a presença de eosinófilos e plasmócitos. Não foi observada a presença de neutrófilos.

Pode-se observar que houve uma pequena diminuição na proliferação fibroblástica (média=1,7) em relação ao período inicial, e um aumento da proliferação angioblástica (média=2,0) e da densidade do fibrosamento. $O$ fibrosamento com densidade moderada (média=2,0), apresentou-se com organização capsular.

O material apresentou-se de forma granular e se localizou, em todos os espécimes, no nível da abertura do tubo.

Não foi observada a presença ou imagem sugestiva de formação de tecido mineralizado, seja periférico ou à distância. 


\subsubsection{Análise microscópica descritiva do infiltrado inflamatório dos fenômenos reparatórios e reações correlatas no período de 60 dias.}

Os dados referentes a esse grupo experimental se encontram no quadro 3 (Anexo 4).

Notou-se, que neste período havia ainda a presença da reação inflamatória, com intensidade moderada (média=1,7).

Observou-se a predominância de macrófagos dispostos na periferia do material, e também à distância. Algumas dessas células apresentavam citoplasma homogêneo, mas a maioria carregada de partículas do material.

As CGMIs, tiveram presença constante, distribuídas na periferia do material. $\mathrm{O}$ grande aumento do número de núcleos dessas células nos chamou atenção, em média 14 núcleos, sendo que em alguns espécimes foram encontradas células com mais de 25 núcleos. Os citoplasmas continham partículas do material e tinham contorno irregular. Os núcleos estavam distribuídos ao acaso, característico de uma reação do tipo corpo estranho.

Notou-se a presença freqüente de linfócitos, eventual presença de eosinófilos e plasmócitos, e nenhum neutrófilo.

Pode-se observar que houve novamente uma diminuição na proliferação fibroblástica (média=1,6) em relação aos períodos anteriores, enquanto que a proliferação angioblástica permaneceu moderada (média=1,9).

O fibrosamento teve sua densidade aumentada (média=2,1), apresentando-se de forma capsular e bem organizada na maioria dos espécimes.

Não foi observada a presença ou imagem sugestiva de formação de tecido mineralizado, seja periférico ou à distância. 


\section{ASPECTOS MICROSCÓPICOS DO GRUPO I ProRoot MTA}

Figura 13A Reação tecidual aos 15 dias, caracterizada por um tecido neoformado (H.E.- 5x).

Figura 13B Maior aumento da figura 13A, onde se observa grande proliferação fibroblástica e partículas do material nos macrófagos (H.E.- 40x).

Figura 13C Reação tecidual aos 30 dias, assumindo o aspecto de fibrosamento. (H.E.- 5x).

Figura 13D Maior aumento da figura 13C, onde se observa as fibras colágenas mais organizadas com fibroblastos com aspecto de menor atividade (H.E.- 40x).

Figura 13E Reação tecidual aos 60 dias, destaca-se a organização da cápsula fibrosa (H.E.- 5x).

Figura 13F Maior aumento da figura 13E, evidenciando o infiltrado inflamatório ainda existente, composto por macrófagos e linfócitos. Presença de neoformação angioblástica (H.E.- 40x).

Figuras 13G, 13I e 13K Visão geral do tecido conjuntivo adjacente a guta-percha (controle) na abertura do tubo, nos períodos de 15, 30 e 60 dias, respectivamente (H.E.- 5x).

Figuras $13 \mathrm{H}, 13 \mathrm{~J}$ e $13 \mathrm{~L}$ Maiores aumentos das figuras 13G, 13l e 13K. Em H destaca-se uma CGMI com muitos núcleos. Nas figuras $13 \mathrm{~J}$ e 13L, nota-se 0 aumento da densidade de fibrosamento e discreto infiltrado inflamatório (H.E.- 40x). 


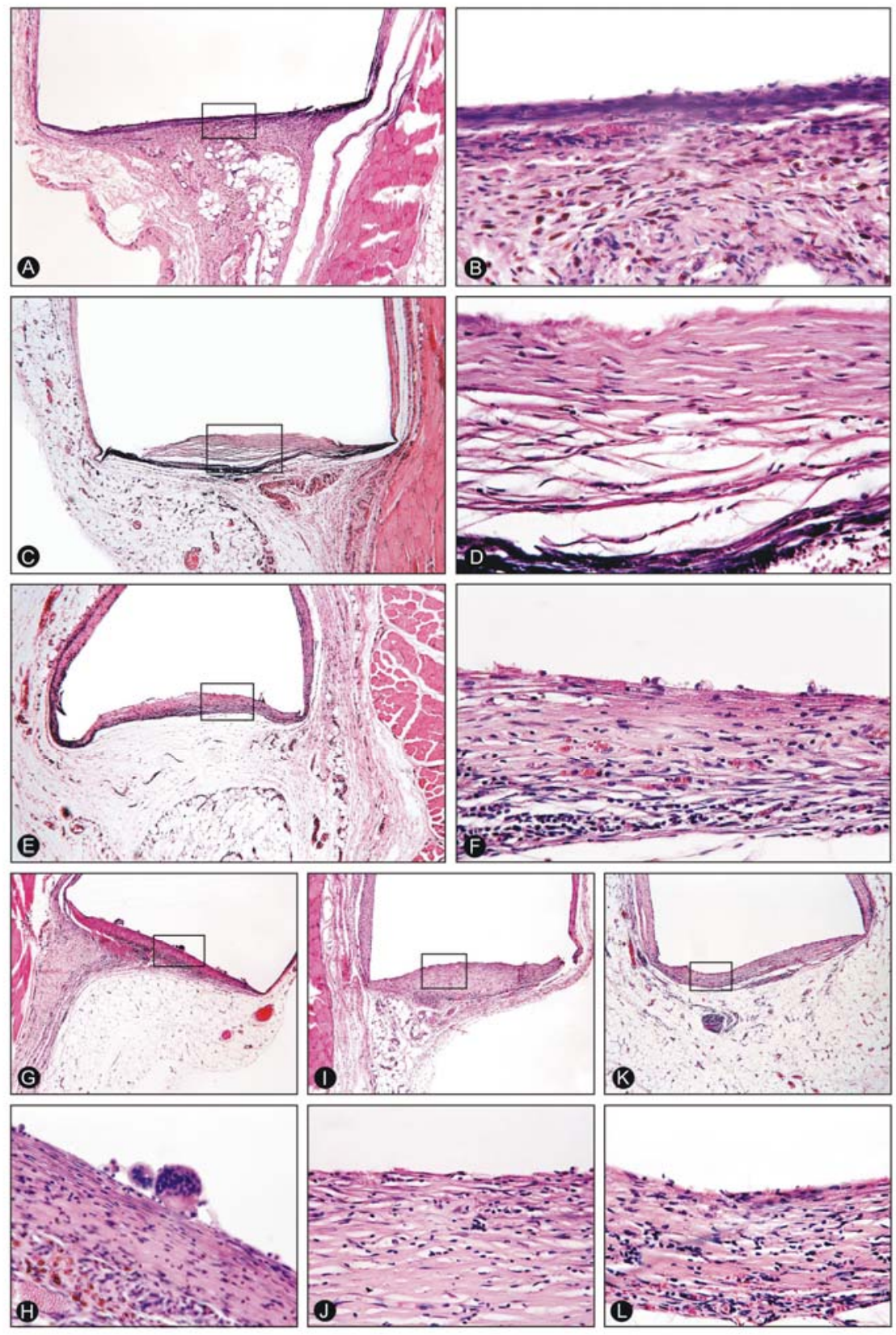




\subsection{MTA Branco com sulfato de bário - Grupo II}

\subsubsection{Análise microscópica descritiva do infiltrado inflamatório dos fenômenos reparatórios e reações correlatas no período de 15 dias.}

As observações referentes a esse grupo experimental encontram-se registradas no quadro 4 (Anexo 5).

Neste material, a intensidade da inflamação mostrou-se moderada na maioria dos espécimes (média=1,88), sendo que em dois foi discreta e intensa em um deles.

Os macrófagos foram as células que predominaram juntamente com um infiltrado mononuclear. Os macrófagos que se dispunham nas proximidades do material e a distância, apresentavam citoplasmas com aspecto homogêneo e também carregados de partículas.

Observou-se também em todos os espécimes a presença de CGMIs contendo em média de 2 a 8 núcleos, e estavam relacionadas com a superfície do material. Em um dos espécimes, o que apresentou intensidade inflamatória intensa, encontrou-se a presença de uma CGMIs do tipo Langhans.

Não foi observada a presença de neutrófilos e os eosinófilos foram eventuais. Os linfócitos foram achados constantes, como também os plasmócitos, o que nos chamou atenção, presentes em mais de $60 \%$ dos espécimes.

Observou-se poucos vasos hiperêmicos e na maioria dos espécimes havia hemorragia.

Tanto a proliferação fibroblástica e angioblástica como a densidade do fibrosamento mostraram-se moderados (médias respectivas $=1,88 ; 2,0$; $2,0)$.

A organização do fibrosamento observada foi predominantemente capsular. 
Não foi observada a presença ou imagem sugestiva de formação de tecido mineralizado, seja periférico ou à distância.

\subsubsection{Análise microscópica descritiva do infiltrado inflamatório} dos fenômenos reparatórios e reações correlatas no período de 30 dias.

Os dados referentes a este grupo experimental encontram-se no quadro 5 (Anexo 6).

Aos 30 dias, a intensidade inflamatória foi predominantemente moderada (média=2,1), sendo intensa em apenas um espécime. Observouse em todos espécimes macrófagos dispostos na periferia do material, e alguns à distância, apresentando em sua maioria citoplasma carregado de partículas do material, sendo outros homogêneos.

Em 100\% dos espécimes houve a presença de CGMIs, distribuídas próximas e na periferia do material; continham em média cinco núcleos, alguns continham no citoplasma partículas do material e outros possuíam aspecto homogêneo. O contorno citoplasmático mostrou-se irregular em 100\% dessas células. Os núcleos estavam distribuídos ao acaso, característico de uma reação do tipo corpo estranho.

$\mathrm{Na}$ proximidade do material pode-se notar freqüentemente a presença de linfócitos e plasmócitos. Foram encontrados eventuais eosinófilos e nenhum neutrófilo .

As proliferações fibroblástica e angioblástica mostraram-se moderadas (médias $=2,0 ; 1,8$ ) e o fibrosamento com densidade também moderada (média=1,8) apresentou-se com organização capsular.

O material apresentou-se de forma granular e se localizou, em todos os espécimes, no nível da abertura do tubo.

Não foi observada a presença ou imagem sugestiva de formação de tecido mineralizado, seja periférico ou à distância. 


\subsubsection{Análise microscópica descritiva do infiltrado inflamatório, dos fenômenos reparatórios e reações correlatas no período de 60 dias.}

Os dados referentes a esse grupo experimental se encontram no quadro 6 (Anexo 7).

Notou-se, que neste período havia ainda a presença da reação inflamatória, com intensidade moderada (média=1,8).

Observou-se a predominância de macrófagos dispostos na periferia do material. Essas células apresentavam-se tanto com o citoplasma homogêneo, como também carregado de partículas do material.

As CGMIs, tiveram presença constante (100\%), distribuídas na periferia do material. O grande aumento do número de núcleos dessas células, de 7 a 20 núcleos, chamou a atenção novamente. Os citoplasmas apresentavam-se com aspecto homogêneo e muitos continham partículas do material, e o contorno era irregular. Os núcleos estavam distribuídos ao acaso, característico de uma reação do tipo corpo estranho.

Curiosamente, neste período, encontrou-se linfócitos em somente $50 \%$ dos espécimes, e os plasmócitos e os polimorfonucleares não estavam presentes.

Pode-se observar que houve novamente uma pequena diminuição na proliferação fibroblástica (média=1,8) em relação aos períodos anteriores, enquanto que o fibrosamento teve sua densidade aumentada (média=2,1), apresentando-se de forma capsular e bem organizada na maioria dos espécimes. Quanto à proliferação angioblástica permaneceu moderada (média=1,9).

Não foi observada a presença ou imagem sugestiva de formação de tecido mineralizado, seja periférico ou à distância. 


\section{ASPECTOS MICROSCÓPICOS DO GRUPO II MTA Branco com sulfato de bário}

Figura 14A Reação tecidual aos 15 dias, destaca-se a fina cápsula fibrosa (H.E.$5 x)$.

Figura 14B Maior aumento da figura 14A, evidenciando partículas de coloração escura do material e macrófagos tentando fagocitá-las. Presença de grande proliferação angioblástica (H.E.- 40x).

Figura 14C Reação tecidual aos 30 dias, destaca-se pelo aumento da cápsula fibrosa (H.E.- 5x).

Figura 14D Maior aumento da figura 14C, presença acentuada de células mononucleares e hemorragia (H.E.- 40x).

Figura 14E Reação tecidual aos 60 dias, destaca-se a grau de fibrosamento, com a invaginação do tecido neoformado para dentro do tubo (H.E.-5x).

Figura 14F Maior aumento da figura 14E, evidenciando o tecido conjuntivo denso permeado por fibroblastos e acúmulo células na extremidade do tecido (H.E.- 40x).

Figuras 14G, 14I e 14K Visão geral do tecido conjuntivo adjacente a guta-percha (controle) na abertura do tubo, aos 15, 30 e 60 dias, respectivamente (H.E.-5x).

Figuras $14 \mathrm{H}, 14 \mathrm{~J}$ e $14 \mathrm{~L}$ Maiores aumentos das figuras $14 \mathrm{G}, 14 \mathrm{I}$ e $14 \mathrm{~K}$. Em H encontram-se partículas dentro do tecido. Nas figuras $14 \mathrm{~J}$ e $14 \mathrm{~L}$, nota-se o aumento da densidade de fibrosamento e em $\mathrm{L}$ o infiltrado inflamatório esta praticamente ausente (H.E.- 40x). 


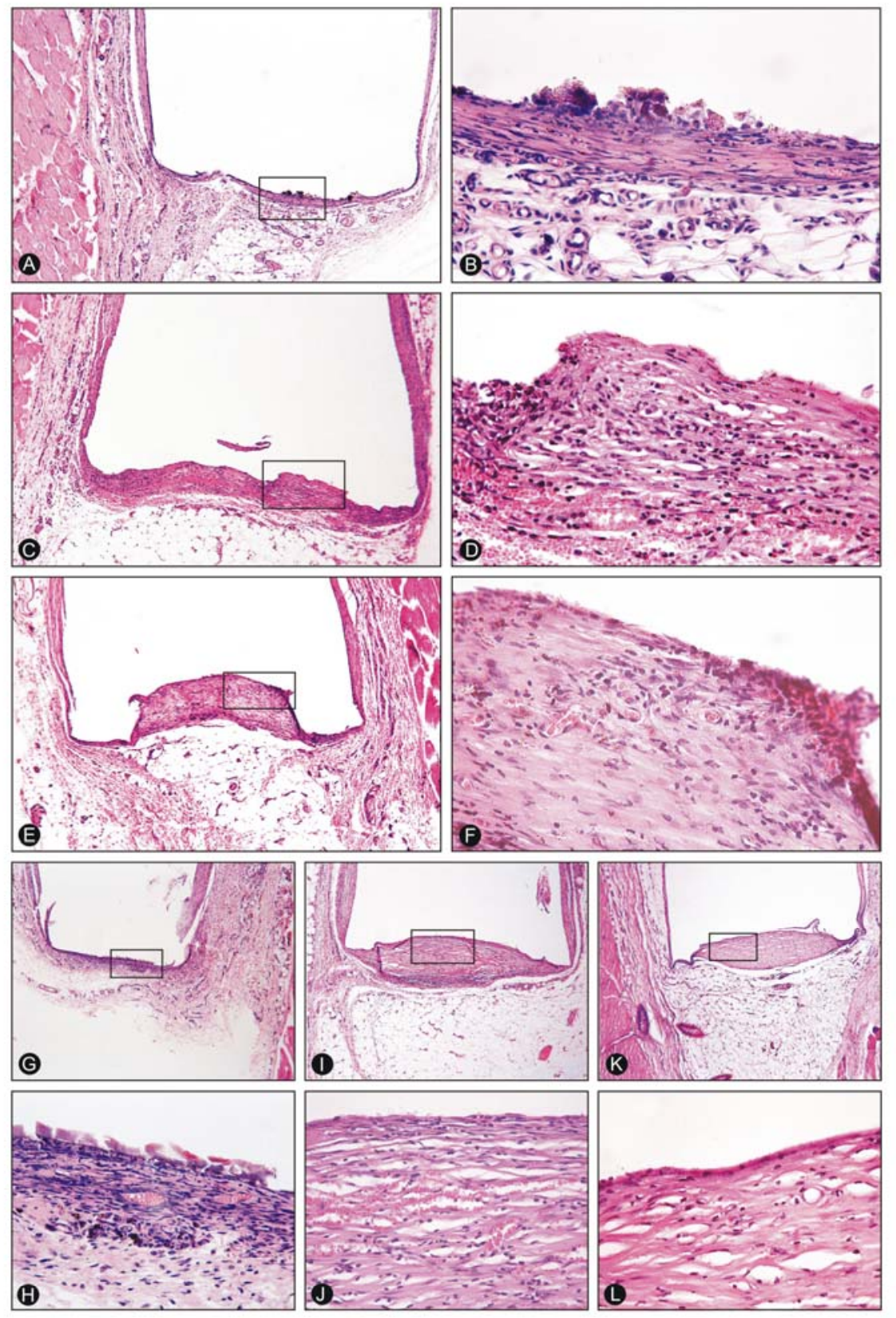




\subsection{MTA Branco com óxido de bismuto - Grupo III}

\subsubsection{Análise microscópica descritiva do infiltrado inflamatório dos fenômenos reparatórios e reações correlatas no período de 15 dias.}

Os dados referentes a esse grupo experimental se encontram no quadro 7 (Anexo 8).

A intensidade inflamatória apresentou-se moderada em média $(1,88)$, com predomínio de mononucleares (macrófagos, linfócitos e plasmócitos), seguido de células gigantes inflamatórias e células polimorfonucleares (neutrófilos e eosinófilos), sendo que estes últimos foram ocasionais.

Os macrófagos que se dispunham na periferia do material, apresentavam citoplasmas com aspecto homogêneo e também carregados de partículas.

Foram encontradas CGMIs em $70 \%$ dos espécimes, estas apresentavam, em média, 4 núcleos, e estavam localizadas na periferia do material.

Observaram-se vasos hiperêmicos e a presença de hemorragia em 50 e 30\% dos espécimes, respectivamente.

Neste grupo a proliferação fibroblástica apresentou escore médio de 2,11, sendo considerada moderada. A proliferação angioblástica e a densidade do fibrosamento mostraram-se moderados (1,66 e 1,77), com valores médios inferiores aos grupos anteriormente descritos.

A organização do fibrosamento observada foi predominantemente capsular.

O material permaneceu no nível da abertura do tubo de polietileno, sendo fagocitável em todas as situações.

Não foi observada a presença ou imagem sugestiva de formação de tecido mineralizado, seja periférico ou à distância. 


\subsubsection{Análise microscópica descritiva do infiltrado inflamatório dos fenômenos reparatórios e reações correlatas no período de 30 dias.}

Os dados referentes a este grupo experimental encontram-se no quadro 8 (Anexo 9).

Aos 30 dias, a intensidade inflamatória foi predominantemente moderada (média=2,1), sendo intensa em dois espécimes e discreta em um. Observou-se em todos espécimes macrófagos dispostos na periferia do material, e alguns à distância, apresentando em sua maioria citoplasma carregado de partículas do material, e outros com aspecto homogêneo.

As CGMIs estavam distribuídas próximas e na periferia do material, continham de 5 a 10 núcleos, possuindo em seus citoplasmas partículas do material. Os núcleos estavam distribuídos ao acaso, característico de uma reação do tipo corpo estranho, e o contorno citoplasmático dessas células mostraram-se irregular. Em um espécime encontramos uma CGMI do tipo Langhans, com núcleos periféricos e contorno citoplasmático regular.

Pode-se notar freqüente presença de linfócitos e plasmócitos. Foram encontrados eventuais eosinófilos e nenhum neutrófilo .

As proliferações fibroblástica e angioblástica mostraram-se moderadas, em média 1,9 e 1,8 respectivamente, e o fibrosamento com densidade também moderada (média=1,8) apresentou-se com organização capsular.

O material apresentou-se de forma granular e se localizou, em todos os espécimes, no nível da abertura do tubo.

Não foi observada a presença ou imagem sugestiva de formação de tecido mineralizado, seja periférico ou à distância. 


\subsubsection{Análise microscópica descritiva do infiltrado inflamatório dos fenômenos reparatórios e reações correlatas no período de 60 dias.}

Os dados referentes a esse grupo experimental se encontram no quadro 9 (Anexo 10).

Notou-se, que neste período havia ainda a presença da reação inflamatória, com intensidade discreta a moderada (média=1,9).

Observou-se a predominância de macrófagos dispostos na periferia do material, e também à distância. Algumas dessas células apresentavam citoplasma homogêneo como também carregadas de partículas do material.

As CGMIs, tiveram presença constante, distribuídas na periferia do material. O grande aumento do número de núcleos dessas células também chamou a atenção, que era em média 10 núcleos, sendo que em alguns espécimes foram encontradas células com mais de 15 núcleos. Os citoplasmas continham partículas do material e tinham contorno irregular. Os núcleos estavam distribuídos ao acaso, característico de uma reação do tipo corpo estranho.

Notou-se a presença freqüente de linfócitos, eventual presença de eosinófilos e plasmócitos, e nenhum neutrófilo.

Pode-se observar que houve uma diminuição na proliferação fibroblástica (média=1,6) em relação ao período inicial e de 30 dias, enquanto que a proliferação angioblástica permaneceu moderada (média=1,8).

O fibrosamento teve sua densidade aumentada em relação aos outros períodos (média=2,2), e apresentando-se de forma capsular e bem organizada na maioria dos espécimes.

Não foi observada a presença ou imagem sugestiva de formação de tecido mineralizado, seja periférico ou à distância. 


\section{ASPECTOS MICROSCÓPICOS DO GRUPO III MTA Branco com óxido de bismuto}

Figura 15A Reação tecidual aos 15 dias, evidenciando cápsula fibrosa já organizada (H.E.- 5x).

Figura 15B Maior aumento da figura 15A, onde se vê a disposição dos feixes de fibras colágenas com poucos fibroblastos (H.E.- 40x).

Figura 15C Reação tecidual aos 30 dias, destaca-se pelo aumento da cápsula fibrosa (H.E.- 5x).

Figura 15D Maior aumento da figura 15C, presença acentuada de células mononucleares. Presença de CGMI e área de necrose superficial do tecido (H.E.40x).

Figura 15E Reação tecidual aos 60 dias frente o material implantado (H.E.- 5x).

Figura 15F Maior aumento da figura 15E, evidenciando o tecido conjuntivo denso permeado por fibroblastos, e com partículas do material no interior de macrófagos (H.E.- 40x).

Figuras 15G, 15I e 15K Visão geral do tecido conjuntivo adjacente a guta-percha (controle) na abertura do tubo, aos 15, 30 e 60 dias, respectivamente (H.E.- 5x).

Figuras $15 \mathrm{H}, 15 \mathrm{~J}$ e 15L Maiores aumentos das figuras 15G, 15I e 15K. Em H é visto abaixo da cápsula fibrosa um intenso infiltrado inflamatório. Em J e L, nota-se o aumento da densidade de fibrosamento, com menos fibroblastos entre as fibras no período de 60 e praticamente ausência de inflamação (H.E.- 40x). 


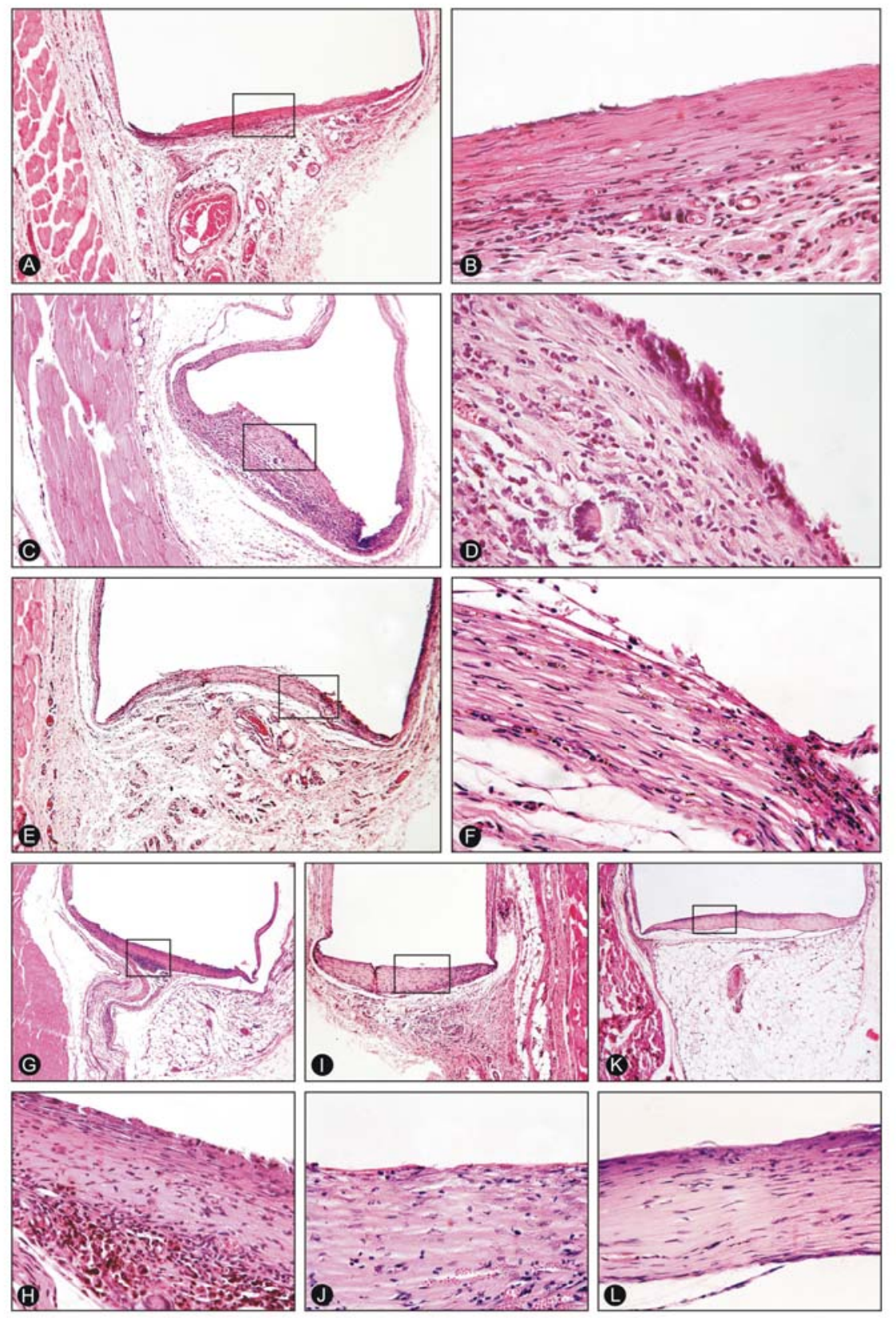




\subsection{Cimento Portland branco (Irajazinho) - Grupo IV}

\subsubsection{Análise microscópica descritiva do infiltrado inflamatório dos fenômenos reparatórios e reações correlatas no período de 15 dias.}

As observações referentes a esse grupo experimental encontram-se registradas no quadro 10 (Anexo 11).

Neste material, a intensidade da inflamação mostrou-se moderada (média $=2,0$ ) na maioria dos espécimes $(90 \%)$, sendo intensa em apenas um.

Os macrófagos foram as células que predominaram juntamente com polimorfonucleares eosinófilos. Poucos e eventuais neutrófilos e mononucleares (linfócitos e plasmócitos) foram encontrados. Os macrófagos que se dispunham nas proximidades do material e alguns à distância, apresentavam citoplasmas com aspecto homogêneo ou carregados de partículas.

Observou-se também em todos os espécimes a presença de CGMIs contendo em média 6 núcleos, que se distribuíam ao acaso dentro da célula, do tipo corpo estranho. Apresentavam citoplasma com aspecto homogêneo, muitos carregados com partículas do material e com contorno irregular.

Observou-se poucos vasos hiperêmicos e praticamente ausência de hemorragia.

A proliferação fibroblástica mostrou-se moderada (média=1,8), já a proliferação angioblástica foi discreta (média=1,3). A densidade do fibrosamento mostrou-se discreta a moderada (média $=1,5$ ).

A organização do fibrosamento observada foi predominantemente capsular.

Curiosamente, observamos em $50 \%$ dos espécimes a presença de cristais, provenientes do material, circundados por células inflamatórias. Estes tinham forma poligonal e aparência hialina.

Não foi observada a presença ou imagem sugestiva de formação de tecido mineralizado, seja periférico ou à distância. 


\subsubsection{Análise microscópica descritiva do infiltrado inflamatório dos fenômenos reparatórios e reações correlatas no período de 30 dias.}

Os dados referentes a este grupo experimental encontram-se no quadro 11 (Anexo 12).

Os resultados histológicos observados nesse período mostravam-se semelhantes aos observados aos 15 dias, com predominância de macrófagos dispostos na periferia do material, e também à distância. Muitas dessas células apresentavam citoplasma homogêneo, mas a maioria carregada de partículas do material.

As CGMIs estavam distribuídas próximas e na periferia do material, continham em média 10 núcleos, possuindo em seus citoplasmas partículas do material. Os núcleos estavam distribuídos ao acaso, característico de uma reação do tipo corpo estranho e o contorno citoplasmático dessas células mostraram-se irregular. Em três espécimes encontrou-se CGMIs do tipo Langhans, com núcleos periféricos e contorno citoplasmático regular.

Na proximidade do material pôde-se ver freqüentemente um infiltrado linfo-plasmocitário. A presença de eosinófilos foi ocasional e nenhum neutrófilo foi encontrado.

A proliferação fibroblástica manteve-se moderada (média=1,9), já a proliferação angioblástica foi diminuída (média=1,3). Houve um pequeno aumento da densidade do fibrosamento (média=1,7) em relação ao período inicial, sendo considerado moderado e com organização capsular.

O material apresentou-se de forma granular e se localizou, em todos os espécimes, no nível da abertura do tubo.

Nos espécimes deste período também se observou a presença de cristais em maior porcentagem (70\%). Estes, provavelmente provenientes do material, tinham forma poligonal, aparência hialina e apresentavam-se circundados por células inflamatórias.

Não foi observada a presença ou imagem sugestiva de formação de tecido mineralizado, seja periférico ou à distância. 


\subsubsection{Análise microscópica descritiva do infiltrado inflamatório dos fenômenos reparatórios e reações correlatas no período de 60 dias.}

Os dados referentes a esse grupo experimental se encontram no quadro 12 (Anexo 13).

A inflamação ainda persistiu neste período, apresentando intensidade moderada na maioria dos espécimes (média=2,1).

Observou-se a predominância de macrófagos dispostos na periferia do material e alguns à distância. Essas células apresentavam tanto 0 citoplasma homogêneo, como também carregado de partículas do material.

As CGMIs, tiveram presença constante (100\%), distribuídas na periferia do material. Houve um aumento do número de núcleos dessas células, em média 11 núcleos, que estavam distribuídos ao acaso, característico de uma reação do tipo corpo estranho. Os citoplasmas dessas células apresentavam-se com aspecto homogêneo e muitos continham partículas do material e o contorno era irregular.

Neste período, encontrou-se polimorfonucleares ocasionais, enquanto que linfócitos e plasmócitos foram vistos com maior freqüência.

Pôde-se observar que houve uma pequena diminuição na proliferação fibroblástica (média=1,6) em relação aos períodos anteriores, enquanto a proliferação angioblástica aumentou (média=2,0). O fibrosamento teve sua densidade novamente aumentada (média=1,9), apresentando-se de forma capsular e bem organizada na maioria dos espécimes.

Observou-se novamente, em alguns espécimes deste período, a presença de cristais (40\%). Estes, provavelmente provenientes do material, tinham forma poligonal, aparência hialina e apresentavam-se circundados por células inflamatórias.

Não foi observada a presença ou imagem sugestiva de formação de tecido mineralizado, seja periférico ou à distância. 


\section{ASPECTOS MICROSCÓPICOS DO GRUPO IV Cimento Portland branco com óxido de bismuto}

Figura 16A Reação tecidual aos 15 dias, evidenciando cápsula fibrosa muito fina (H.E.- 5x).

Figura 16B Maior aumento da figura 16A, onde se vê grande hemorragia, fibroblastos envoltos por poucas fibras colágenas e partículas escuras do material cercada por macrófagos. Destacam-se cristais com forma poligonal e aparência hialina (setas), circundados por células inflamatórias (H.E.- 40x).

Figura 16C Reação tecidual aos 30 dias, destaca-se pelo aumento da cápsula fibrosa (H.E.- 5x).

Figura 16D Maior aumento da figura 16C, presença acentuada de células mononucleares. Presença fragmentos do material nos macrófagos (H.E.- 40x).

Figura 16E Reação tecidual aos 60 dias frente o material implantado (H.E.- 5x).

Figura 16F Maior aumento da figura 16E, evidenciando o tecido conjuntivo denso com muitos fibroblastos, e com cristais provavelmente do material no seu interior (H.E.- 40x).

Figuras 16G, 16I e 16K Visão geral do tecido conjuntivo adjacente a guta-percha (controle) na abertura do tubo, aos 15, 30 e 60 dias, respectivamente (H.E.- 5x).

Figuras 16H, 16J e 16L Maiores aumentos das figuras 16G, 16I e 16K. Em H observa-se grande quantidade do material na interface. Na figura $16 \mathrm{I}$ destaca-se a grande proliferação fibroblástica, já na $16 \mathrm{~L}$ diminuição do número de célula e grande aumento da densidade do fibrosamento, com praticamente ausência de inflamação (H.E.- 40x). 

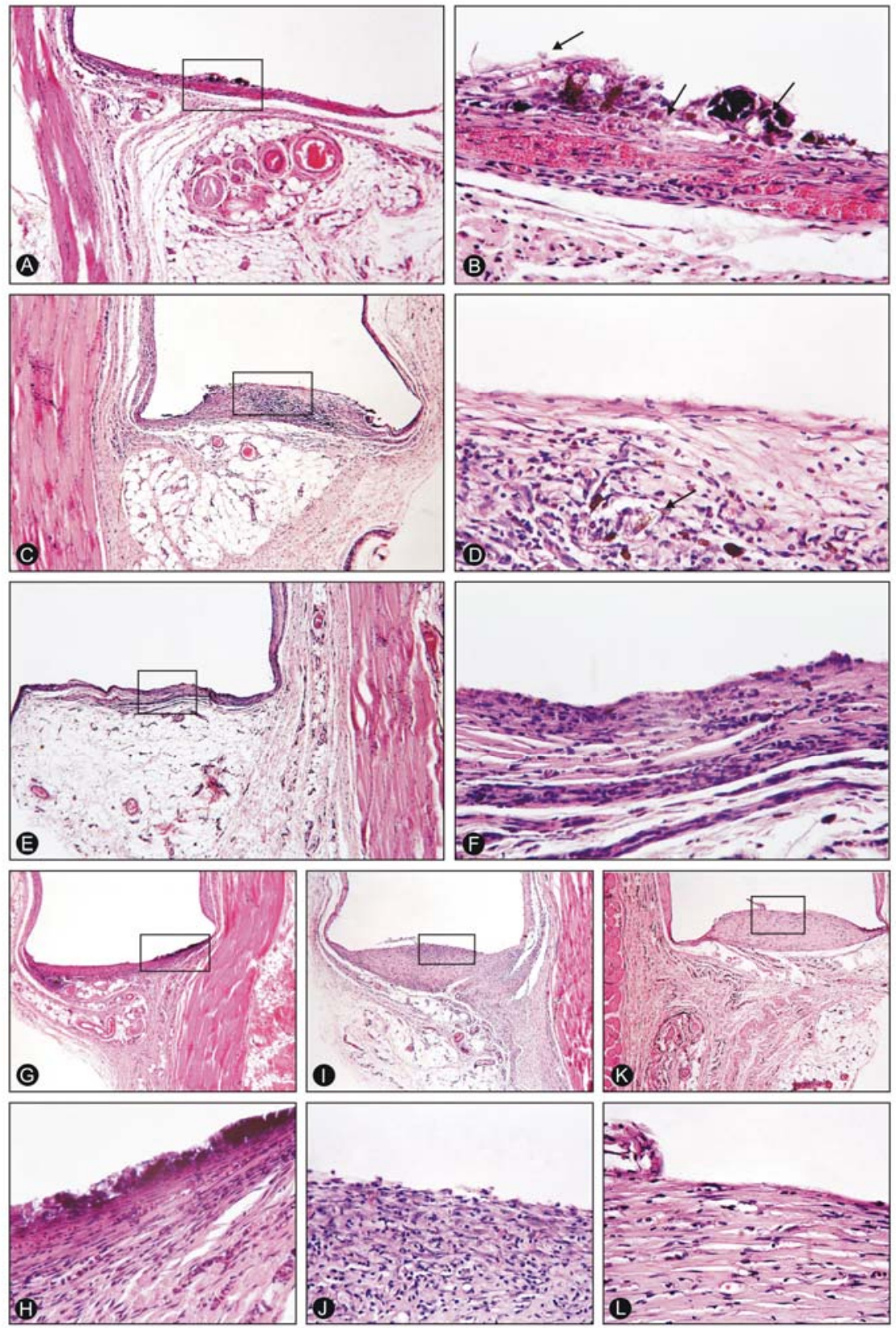


\subsection{Guta-percha (Controle) - Grupo V}

\subsubsection{Análise microscópica descritiva do infiltrado inflamatório dos fenômenos reparatórios e reações correlatas nos períodos de 15, 30 e 60 dias.}

Os dados referentes a esse grupo experimental se encontram no quadro 13 (Anexo 14).

O grupo controle constituiu-se inicialmente de 160 espécimes, 48 para os períodos de 15 e 30 dias e 64 para o período de 60 dias. Deste total houve 52 perdas. Para os itens da análise estatística que receberam escores (intensidade inflamatória, proliferação fibroblástica, proliferação angioblástica e densidade do fibrosamento) todas as lâminas foram analisadas, porém, para a análise descritiva, foi selecionada aleatoriamente, uma lâmina de cada grupo em cada período experimental, descritas a seguir.

Aos 15 dias, observou-se processo inflamatório crônico com intensidade moderada (média=2,17), composto por células mononucleares (macrófagos, linfócitos) próximas ao material.

Os macrófagos interagiram intensamente e diretamente com a gutapercha, distribuídas também na periferia, possuíam tamanho normal, com citoplasma por vezes carregado de partículas do material. Os núcleos dessas células apresentaram-se normais e com forma regular.

Em alguns espécimes, observou-se a formação de células gigantes multinucleadas inflamatórias (CGMIs). Essas células estavam distribuídas próximas e na periferia do material, possuíam mais de 15 núcleos (Figura $15 \mathrm{H})$, com contorno citoplasmático irregular. Os núcleos estavam distribuídos ao acaso, característico de uma reação do tipo corpo estranho.

Ocasionalmente, verificaram-se neutrófilos e eosinófilos. Em alguns espécimes, junto ao infiltrado inflamatório, pode-se observar alguns plasmócitos. 
Quanto aos fenômenos reparatórios, observou-se moderada proliferação fibroblástica (média=2,26) e angioblástica (média=1,7). $\mathrm{O}$ fibrosamento apresentou com discreta densidade (média=1,35), e com organização capsular.

O material apresentou-se de forma granular microscopicamente e se localizou, na maioria dos espécimes, ao nível da abertura do tubo.

Os resultados histológicos observados no período de 30 dias mostraram-se semelhantes aos observados no período anterior, a intensidade inflamatória continuou modera (menor média dos grupos=1,89), com predominância de macrófagos dispostos na periferia do material, e também à distância. Algumas dessas células apresentavam citoplasma homogêneo, e outras com partículas do material.

A presença das CGMIs, ao contrário dos outros grupos, não foi constante, quando encontradas localizavam-se próximas à guta-percha.

Pode-se observar que houve uma pequena diminuição na proliferação fibroblástica (média=2,08) e da proliferação angioblástica (média=1,45) em relação ao período inicial. O fibrosamento com densidade moderada (média=1,59), em média, apresentou-se com organização capsular.

Notou-se, no período de 60 dias que ainda havia a presença da reação inflamatória, com intensidade discreta a moderada (menor média dos grupos=1,40), sendo que em alguns espécimes foi ausente.

A proliferação fibroblástica foi bastante diminuída (média=1,37) e proliferação angioblástica mostrou-se discreta (média=1,32).

O fibrosamento teve sua densidade aumentada (maior média dos grupos $=2,43$ ), apresentando-se de forma capsular e bem organizada na maioria dos espécimes.

Não foi observada a presença ou imagem sugestiva de formação de tecido mineralizado, seja periférico ou à distância, nos três períodos. 


\subsection{Análise estatística da intensidade inflamatória, proliferação fibroblástica, proliferação angioblástica e densidade do fibrosamento, caracterizados por escores, nos três períodos experimentais.}

Aplicou-se o teste não-paramétrico de Kruskal-Wallis utilizando os escores dos cinco grupos experimentais. Realizou-se o teste para comparação entre grupos em cada período (15, 30, 60 dias), como também para cada material nos três períodos experimentais (Tabelas $4,5,6,7$ ).

A análise mostrou não haver diferença estatisticamente significante entre os grupos nos períodos experimentais ( $p>0,001)$, nem dos materiais em relação ao tempo, exceto nos casos descritos em cada tópico a seguir.

\subsubsection{Intensidade da inflamação}

Tabela 4 - Médias dos escores da intensidade inflamatória dos grupos nos três períodos experimentais; comparação entre os grupos em cada período e comparação de cada material em relação ao tempo.

\begin{tabular}{|c|c|c|c|c|}
\hline GRUPOS & 15 dias & 30 dias & 60 dias & $\begin{array}{c}\text { Comparação entre } \\
\text { períodos (Kruskal-Wallis) }\end{array}$ \\
\hline $\begin{array}{l}\text { ProRoot MTA cl } \\
\text { óxido de bismuto }\end{array}$ & 1,77 & 2,20 & 1,70 & $p=0,05$ \\
\hline $\begin{array}{l}\text { MTA Branco cl } \\
\text { sulfato de bário }\end{array}$ & 1,88 & 2,10 & 1,80 & $p=0,31$ \\
\hline $\begin{array}{l}\text { MTA Branco cl } \\
\text { óxido de bismuto }\end{array}$ & 1,88 & 2,10 & 1,90 & $p=0,47$ \\
\hline $\begin{array}{l}\text { Portland branco cl } \\
\text { óxido de bismuto }\end{array}$ & 2,00 & 2,20 & 2,10 & $p=0,68$ \\
\hline $\begin{array}{c}\text { Guta-percha } \\
\text { (Controle) }\end{array}$ & 2,17 & 1,89 & 1,40 & $p=0,00^{*}$ \\
\hline $\begin{array}{l}\text { Comparação entre } \\
\text { os materiais } \\
\text { (Kruskal-Wallis) }\end{array}$ & $p=0,12$ & $p=0,16$ & $p=0,00^{\star *}$ & $\begin{array}{c}\text { *Teste de Dunn (Controle) } \\
15 \times 60=\text { Significante } \\
30 \times 60=\text { Significante } \\
\text { **Teste de Dunn (60 dias) } \\
\text { PortlandxControle=Significante }\end{array}$ \\
\hline
\end{tabular}


Quando se comparou a intensidade inflamatória em cada período experimental, a análise mostrou não haver diferença estatística significante nos períodos de 15 e 30 dias, sendo significante no período de 60 dias. Aplicando-se o teste de Dunn para comparações individuais, constatou-se diferença significante entre o cimento Portland e o grupo controle (gutapercha).

$\mathrm{Na}$ comparação individual de cada material nos três períodos experimentais, o grupo controle apresentou diferença estatística significante. Utilizando novamente o teste de Dunn, verificou-se diferença significante entre os períodos de 30 e 60 dias.

\subsubsection{Proliferação fibroblástica}

Tabela 5 - Médias dos escores da proliferação fibroblástica dos grupos nos três períodos experimentais; comparação entre os grupos em cada período e comparação de cada material em relação ao tempo.

\begin{tabular}{|c|c|c|c|c|}
\hline GRUPO & 15 dias & 30 dias & 60 dias & $\begin{array}{c}\text { Comparação entre } \\
\text { períodos (Kruskal- } \\
\text { Wallis) }\end{array}$ \\
\hline $\begin{array}{l}\text { ProRoot MTA cl } \\
\text { óxido de bismuto }\end{array}$ & 1,88 & 1,70 & 1,60 & $p=0,37$ \\
\hline $\begin{array}{l}\text { MTA Branco cl } \\
\text { sulfato de bário }\end{array}$ & 1,88 & 2,00 & 1,80 & $p=0,52$ \\
\hline $\begin{array}{l}\text { MTA Branco cl } \\
\text { óxido de bismuto }\end{array}$ & 2,11 & 1,90 & 1,60 & $p=0,10$ \\
\hline $\begin{array}{l}\text { Portland branco cl } \\
\text { óxido de bismuto }\end{array}$ & 1,88 & 1,90 & 1,60 & $p=0,18$ \\
\hline Guta-percha (Controle) & 2,26 & 2,08 & 1,37 & $p=0,00^{*}$ \\
\hline $\begin{array}{c}\text { Comparação entre os } \\
\text { materiais (Kruskal- } \\
\text { Wallis) }\end{array}$ & $p=0,08$ & $p=0,04$ & $p=0,25$ & $\begin{array}{c}\text { *Teste de Dunn } \\
\text { (Controle) } \\
15 \times 60=\text { Significante } \\
30 \times 60=\text { Significante }\end{array}$ \\
\hline
\end{tabular}


Aos 30 dias o grupo controle (guta-percha) apresentou maior proliferação fibroblástica, havendo diferença estatística significante.

$\mathrm{Na}$ comparação individual de cada material nos três períodos experimentais, o grupo controle apresentou diferença estatística significante. Utilizando o teste de Dunn, verificou-se diferença significante entre os períodos de 15 e 60 dias, e 30 e 60 dias.

\subsubsection{Proliferação angioblástica}

Tabela 6 - Médias dos escores da proliferação angioblástica dos grupos nos três períodos experimentais, comparação entre os grupos em cada período e comparação de cada material em relação ao tempo.

\begin{tabular}{|c|c|c|c|c|}
\hline GRUPO & 15 dias & 30 dias & 60 dias & $\begin{array}{c}\text { Comparação entre } \\
\text { períodos (Kruskal- } \\
\text { Wallis) }\end{array}$ \\
\hline $\begin{array}{l}\text { ProRoot MTA cl } \\
\text { óxido de bismuto }\end{array}$ & 1,55 & 2,00 & 1,90 & $p=0,26$ \\
\hline $\begin{array}{l}\text { MTA Branco cl } \\
\text { sulfato de bário }\end{array}$ & 2,00 & 1,80 & 1,90 & $p=0,78$ \\
\hline $\begin{array}{l}\text { MTA Branco cl } \\
\text { óxido de bismuto }\end{array}$ & 1,66 & 1,80 & 1,80 & $p=0,86$ \\
\hline $\begin{array}{l}\text { Portland branco cl } \\
\text { óxido de bismuto }\end{array}$ & 1,33 & 1,30 & 2,00 & $p=0,00^{*}$ \\
\hline $\begin{array}{c}\text { Guta-percha } \\
\text { (Controle) } \\
\text { Comparação entre }\end{array}$ & 1,70 & 1,45 & 1,32 & $\begin{array}{c}\mathrm{p}=0,07 \\
\text { *Teste de Dunn }\end{array}$ \\
\hline $\begin{array}{c}\text { os materiais } \\
\text { (Kruskal-Wallis) }\end{array}$ & $p=0,24$ & $p=0,08$ & $p=0,002$ & $\begin{array}{c}\text { (Portland) } \\
30 \times 60=\text { Significante }\end{array}$ \\
\hline
\end{tabular}

Aos 60 dias o grupo controle (guta-percha) apresentou menor proliferação angioblástica, havendo diferença estatística significante.

$\mathrm{Na}$ comparação individual de cada material nos três períodos experimentais, o grupo do cimento Portland apresentou diferença estatística significante. Utilizando o teste de Dunn, verificou-se diferença significante entre os períodos de 30 e 60 dias. 


\subsubsection{Densidade do fibrosamento}

Tabela 7 - Médias dos escores da densidade do fibrosamento dos grupos nos três períodos experimentais, comparação entre os grupos em cada período e comparação de cada material em relação ao tempo.

\begin{tabular}{|c|c|c|c|c|}
\hline GRUPO & 15 dias & 30 dias & 60 dias & $\begin{array}{c}\text { Comparação entre } \\
\text { períodos (Kruskal- } \\
\text { Wallis) }\end{array}$ \\
\hline $\begin{array}{l}\text { ProRoot MTA cl } \\
\text { óxido de bismuto }\end{array}$ & 1,66 & 2,00 & 2,10 & $p=0,26$ \\
\hline $\begin{array}{l}\text { MTA Branco cl } \\
\text { sulfato de bário }\end{array}$ & 2,00 & 1,80 & 2,10 & $p=0,49$ \\
\hline $\begin{array}{l}\text { MTA Branco cl } \\
\text { óxido de bismuto }\end{array}$ & 1,77 & 1,80 & 2,20 & $p=0,13$ \\
\hline $\begin{array}{l}\text { Portland branco cl } \\
\text { óxido de bismuto }\end{array}$ & 1,55 & 1,70 & 1,90 & $p=0,39$ \\
\hline $\begin{array}{c}\begin{array}{c}\text { Guta-percha } \\
\text { (Controle) }\end{array} \\
\text { Comparação entre os } \\
\text { materiais (Kruskal- } \\
\text { Wallis) }\end{array}$ & $p=0,01$ & $p=0,26$ & $p=0,11$ & $\begin{array}{c}p=0,00 * \\
* \text { Teste de Dunn } \\
\text { (Controle) } \\
15 \times 60=\text { Significante } \\
30 \times 60=\text { Significante }\end{array}$ \\
\hline
\end{tabular}

Aos 15 dias o grupo controle (guta-percha) apresentou menor densidade de fibrosamento e o MTA Branco com sulfato de bário a maior, havendo diferença estatística significante.

$\mathrm{Na}$ comparação individual de cada material nos três períodos experimentais, o grupo controle (guta-percha) apresentou diferença estatística significante. Utilizando o teste de Dunn, verificou-se diferença significante entre os períodos de 15 e 60 dias, e 30 e 60 dias. 


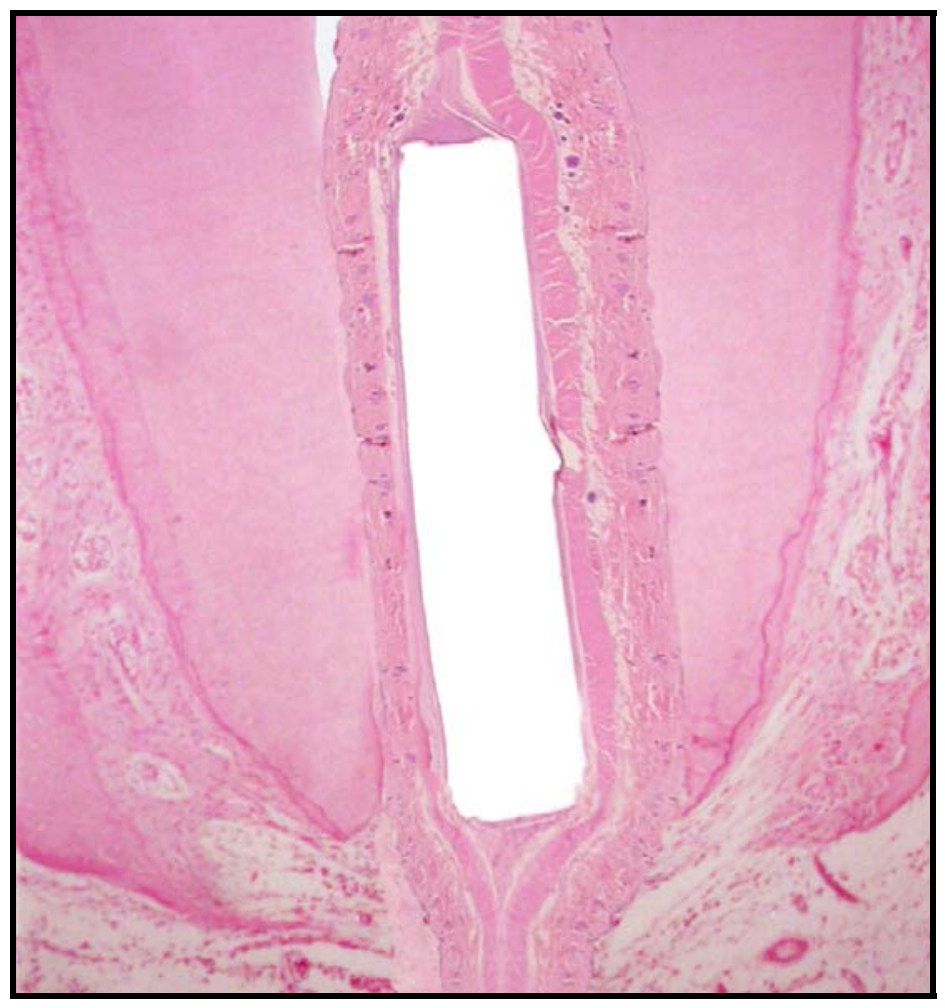

FIGURA 17

Montagem: tubo de polietileno e tecido subcutâneo do rato representando o canal radicular e ligamento periodontal. 


\section{DISCUSSÃO}

\subsection{DA METODOLOGIA}

O rato de laboratório Rattus norvegicus, foi o modelo animal experimental utilizado neste estudo. Segundo HEDRICH ${ }^{65}$ (2000) o rato de laboratório Rattus norvegicus é um dos animais experimentais mais comumente utilizados, sendo o modelo que melhor representa o funcionamento do sistema mamífero. $\mathrm{O}$ rato serve como modelo para a análise de um grande número de importantes especialidades biomédicas, tais como as doenças cardiovasculares, desordens metabólicas e neurológicas, estudos neurocomportamentais, transplante de órgãos, doenças autoimunes, susceptibilidade ao câncer e doenças renais. Ele oferece um modelo único, com grandes vantagens, para se simular as doenças humanas, assim, possibilitando o desenvolvimento de novos agentes terapêuticos, como também o estudo das respostas aos agentes do meio ambiente. O tamanho do rato de laboratório, em contraste com os outros animais experimentais normalmente empregados, faz dele o modelo ideal para seguras experimentações fisiológicas.

Outro campo de pesquisa clínica, a toxicologia, também tem utilizado o rato como uma importante espécie para testes, como pode ser visto na literatura. Além disso, o recente desenvolvimento da genética, e de novas ferramentas genômicas para o rato, fornecem uma oportunidade imprescindível, aproveitando as vantagens da rica e consistente história dos estudos experimentais, para se utilizar esta espécie no estudo das doenças humana. O passado rico e as recentes informações disponíveis sobre o rato, mais a multiplicidade de procedimentos com diferentes características à disposição tornam, esse animal, uma ferramenta indispensável para a pesquisa biomédica.

A reprodução do rato em laboratório permite a eliminação de fatores individuais, como deficiência imune, ou estarem afetados com alguma doença, além de facilitar a obtenção do número de amostras 
necessárias. O rato, por ter um metabolismo mais acelerado, permite a obtenção de resultados num curto período de tempo (RODRIGUES SOSA $^{127}$, 2003). Para o presente estudo foram selecionados ratos machos devido às variações no ciclo hormonal das fêmeas. Os animais tiveram a mesma origem, Biotério da Faculdade de Odontologia de Bauru-USP, e foram padronizados quanto à saúde, idade e peso corporal.

Cada período experimental foi composto por 12 animais inicialmente, depois quatro ratos reservas foram adicionados ao período experimental de 60 dias.

Os ratos têm sido muito utilizados nas pesquisas odontológicas, quando se deseja avaliar as propriedades biológicas dos materiais dentários.

Os testes para avaliação de um material, medicamento ou terapia efetuados em modelos humanos são restringidos, conseqüentemente modelos alternativos são necessários, justificando, assim, o uso de animais como modelos experimentais. A experimentação animal deve ser conduzida apenas após consideração de sua relevância para a saúde do homem.

Vários métodos de estudo das respostas biológicas provocadas por materiais endodônticos foram descritos por LANGELAND et al. ${ }^{95}$ (1969), onde o uso da técnica de implantação de tubos de polietileno em tecido subcutâneo de rato foi recomendada como teste preliminar nas pesquisas de compatibilidade tecidual. Este método, idealizado por DIXON e RICKERT ${ }^{40}$ (1933), depois proposto por MITCHELL ${ }^{106}$ (1959) e refinado por TORNECK ${ }^{167}$ em 1966, é indicado pela ADA ${ }^{6,7,148}$ e FDI F2,147,148,149 $^{\text {como }}$ teste secundário na avaliação biológica da implantação dos materiais. De acordo com a FDI ${ }^{82,147,149}$ este teste é indicado para avaliar in vivo a toxicidade dos materiais quando se deseja contato prolongado com os tecidos subcutâneos (STANFORD, J.W. $\left.{ }^{149}, 1980\right)$.

$\operatorname{cosTA}^{35}$, em 2001, elegeu o teste de implantação de materiais em tecido conjuntivo subcutâneo como a metodologia de nível 2 adequada para avaliar a biocompatibilidade em ratos, descrevendo as seguintes vantagens que este teste oferece: 1) uso de limitada área para a manutenção dos animais; 2) facilidade de limpeza e higienização da área 
reservada a manutenção dos animais no pós-operatório; 3) metodologia de execução relativamente simples, possibilitando o trabalho em vários animais em curto período de tempo; 4) como esta metodologia não envolve tecido calcificado, não há necessidade de descalcificação dos espécimes, o que acelera o processamento laboratorial; 5) a metodologia oferece a possibilidade de comparar a resposta tecidual num mesmo animal, para diversos materiais experimentais implantados, inclusive os materiais usados como controle; 6) o custo para o desenvolvimento da metodologia de implantação é relativamente baixo.

Outras vantagens da aplicação desse método citadas por OLSSON, SLIWKIWSKI, LANGELAND ${ }^{116}$, em 1981, são: permitir a implantação de materiais recentemente manipulados; utilizar a reação das laterais do tubo como controle para a avaliação da severidade do trauma cirúrgico; ser relativamente simples e apropriado para provas rotineiras de materiais endodônticos.

O implante de pastas e cimentos em tecido moles, muitas vezes necessita de veículos especiais que permitam um controle de sua forma e tamanho, conforme sugeriu TORNECK ${ }^{167}$ (1966). Foram utilizados os tubos de polietileno, técnica muito difundida e ainda utilizada, pela sua vantagem de imitar as condições do canal radicular (Figura 17), uma vez que apenas nas porções terminais do tubo é que o material entra em contato com 0 tecido (FRIEND e BROWNE ${ }^{57}$, 1968; ZMENER, GUGLIELMOTTI, CABRINI $^{186}$, 1988; FERRAZ et al. $\left.{ }^{51}, 1990\right)$.

MAKKES et al. ${ }^{101}$ (1977) utilizaram os tubos de polietileno por serem veículos sólidos, de fácil manipulação e implantação, não apresentando reação no tecido circunjacente, e por serem quimicamente estáveis e não sofrerem influência de medicamentos que possam ser acondicionados em seu interior.

TORNECK ${ }^{167,168}, \quad$ PHILLIPS $^{121}, \quad$ LANGELAND $^{\text {et }}$ al. $^{95} \mathrm{e}$ GORDYUSUS; ETIKAN; GOKOZ $^{60}$ utilizaram tubos de polietileno para acondicionar as substâncias ou materiais a serem testados. Segundo os autores o tubo não provoca reação inflamatória e permite a movimentação 
do animal. Já KOLOKURIS et al. ${ }^{89,90}$ e OLSSON; SLIWKOWSKI; LANGELAND $^{116}$ utilizaram tubos de teflon. A nossa escolha recaiu pelo tubo de polietileno. Este por ser flexível, permitiu-nos minimizar o trauma cirúrgico durante a implantação, também por terem uma resposta similar aos tubos de teflon e a cápsula ao redor do tubo servir como controle negativo (LANGELAND; OLSSON; PASCON ${ }^{94}, 1981$ ).

Um dos problemas deste método é que o material pode sair do tubo alojando-se no tecido adjacente e assim, produzir diferentes graus de resposta inflamatória para um mesmo período experimental, além de impedir, em alguns casos, a utilização desta área como controle (OLSSON; SLIWKIWSKI; LANGELAND ${ }^{116}$, 1981). Um fator que auxilia na contenção do material no interior dos tubos é o diâmetro, portanto, quanto menor o diâmetro do tubo menor a chance do material espalhar-se pelo tecido. Contudo, deve-se levar em consideração, que um diâmetro muito pequeno irá proporcionar uma área pequena para avaliação microscópica. Desta forma, escolhemos um diâmetro interno de 1,5mm, que proporciona segurança na retenção do material e uma adequada área para análise microscópica. O extravasamento pode também ser controlado com o selamento de uma das extremidades como foi realizado neste estudo, como recomendado por TORNECK ${ }^{167,168}$ e utilizado por ECONOMIADES et al. ${ }^{44}$, 1995. Isto também poderia ser evitado se os tubos fossem implantados após o tempo de presa dos cimentos (KOLOKOURIS et al. ${ }^{89,90}$, OLSSON; SLIWKIWSKI; LANGELAND ${ }^{116}$, 1981; ORSTAVIK e MJÖR ${ }^{117}$, 1988), mas eliminaria a avaliação da alta toxicidade inicial da maioria dos materiais endodônticos antes da presa final (OLSSON; SLIWKIWSKI; LANGELAND $^{116}, 1981$ ), além de não avaliar o seu escoamento.

De acordo com as normas da FDI ${ }^{82,147}$ deve-se realizar quatro implantes por animal, sendo que um dos tubos, vazio, deve servir como controle. Seguindo essas recomendações realizamos quatro implantes por animal da mesma forma que GORDYUSUS et al. $^{60}$, PHILLIPS $^{121}$ e TORNECK ${ }^{167}$, porém não deixamos um dos tubos vazios como controle. A extremidade selada com a guta-percha serviu para este propósito. 
A implantação dos quatro materiais em teste num mesmo animal, em sistema de rodízio, possibilitou um equilíbrio entre regiões e animais, evitando interferência das condições anatômicas, sistêmicas e nutritivas, nas avaliações comparativas dos cimentos.

Para a anestesia dos animais foi utilizada a associação do anestésico Ketamina (Dopalen - Angribrans do Brasil Ltda.) com o relaxante muscular e analgésico Cloridrato de Xilazina (Anasedan - Angribrans do Brasil Ltda.), dosagem determinada pelo peso do animal, que resulta num efeito anestésico por um período aproximado de 40 minutos, especificamente em animais de metabolismo intenso como os ratos. O uso da Ketamina, anestésico geral na anestesia de animais de laboratório faz-se em combinação com o relaxante muscular Xilazina, sedativo e analgésico, que atua no sistema nervoso central induzindo o relaxamento muscular (CONSEJO CANADIENSE DE PROTECCIÓN DE LOS ANIMALES DE EXPERIMENTACIÓN ${ }^{31}$, 1998).

Para minimizar o trauma cirúrgico tem sido proposta a utilização de seringas ou trocartes (POSHADLEY e HARRISON ${ }^{125}$, 1966; SAFAVI; PASCON; LANGELAND ${ }^{130}$, 1983). Neste estudo, fez-se uma pequena incisão, seguida pela divulsão superficial com instrumento rombo e deposição do implante na intimidade do tecido com auxílio de um trocarte. Com relação a esta técnica notamos, durante a análise microscópica fatos que também foram observados por XAVIER et al. ${ }^{181}$ em 1973. O primeiro deles foi uma inconstância quanto ao tipo de tecido com o qual o material testado entrava em contato. Se na maior parte das vezes este tecido era o conjuntivo subcutâneo, em algumas ocasiões era o tecido conjuntivo muscular e noutras o adiposo. Constatamos que as reações teciduais variavam em função deste fato, o que está de acordo com as observações de SPANGBERG ${ }^{145}$ (1969). As diferenças não foram sensíveis quando o tecido era subcutâneo, muscular ou conjuntivo, no adiposo as reações eram mais brandas. Outro fato salientado por XAVIER et al. ${ }^{181}$ (1973) diz respeito às extremidades do tubo de polietileno as quais continham o material que estava em contato os tecidos. A que estava na direção de penetração do 
corpo de prova se justapunha a um tecido pouco traumatizado pelo procedimento da implantação, enquanto a outra estava dirigida para o túnel aberto pela cânula do trocarte. Nestas condições, os fenômenos observados nos tecidos ao redor do material eram um tanto discrepantes entre as duas extremidades, principalmente em períodos iniciais de avaliação. Na primeira questão, às vezes os feixes de fibras eram comprimidos à guisa da pseudocápsula. Assim, as reações inflamatórias e reparativas eram moderadas, em relação à outra extremidade. Nesta, provavelmente logo após a implantação, o material entrava em contato com o coágulo sanguíneo que preenchia o túnel, e a partir dele ocorriam as referidas reações. Esta diferença perturbou a análise conjunta dos fenômenos observados em cada implante. Porém isto não interferiu de maneira a impossibilitar a descrição e graduação em termos médios.

Neste estudo, todos materiais em teste ficaram do lado onde não ocorreu o trauma cirúrgico, sendo padronizada a área a ser analisada. A guta-percha mesmo ficando do lado onde o tecido foi mais traumatizado, apresentou melhor processo de reparo (Tabelas 5, 6, 7), com discreta inflamação nos períodos observados.

Outro fato ainda observado por nós, concordando com XAVIER et al. $^{181}$ (1973), foi que em alguns implantes ocorreu falha no nivelamento da superfície do material em relação à extremidade do tubo, e isto produzia uma concavidade, que era preenchida por invaginação tecidual. Ao contrário do que foi verificado pelos autores, raramente ocorreu a extrusão de material, visto por eles dispersado no interior dos tecidos.

Observamos que o emprego do trocarte, preconizado por PODSHADLEY e HARRISON ${ }^{125}$, e usado com bons resultados por NAGEM FILHO ${ }^{114}$ para indução de corpos de provas sólidos no tecido subcutâneo de ratos, talvez não seja o meio mais apropriado para a implantação de materiais semifluídos contidos em tubos de polietileno. Presumimos que a técnica de implantação que se inicia na derme, divulsionando os tecidos até certa distância para então depositar subcutaneamente o veículo sólido contendo material semifluído, empregado por HOLLAND et al. $^{67,68}$ e 
BROWNE e FRIEND ${ }^{24}$, seja mais apropriada. Isto porque parece permitir melhor discernimento do tecido receptor, evitando dualidade de condições traumáticas ao redor das extremidades do tubo e provocando menor movimentação do material semifluído na luz do veículo. Convém salientar que SAMPAIO ${ }^{133}$ empregou técnica semelhante a que usamos e foi bem sucedido.

A movimentação dos tubos no interior do tecido é outro fator desfavorável deste método, pois é possível haver resposta inflamatória devido a esta movimentação. Contudo, quando se percebe uma cápsula fibrosa envolvendo as paredes laterais do tubo, pode-se deduzir que houve limitação de movimento (OLSSON; SLIMKOWSKI; LANGELAND ${ }^{116}, 1981$ ). O emprego do trocarte é uma boa alternativa, pois o divulsionamento feito por este instrumento é mínimo, restringindo o deslocamento.

Percebemos, no estudo piloto da pesquisa, que pelo método do divulsionamento com tesoura romba, e depois deposição do tubo com auxílio de uma pinça, foi comum a união das áreas de implante de um mesmo lado, como também o deslocamento do tubo de um sítio para outro, ficando dois implantes na mesma posição, e por vezes juntos.

As normas da FDI $^{149}$ recomendam um período curto de avaliação (48h) para determinar os efeitos da incisão e do procedimento operatório. Para avaliar a reação do tecido conjuntivo dos animais em contato com os materiais experimentais e controle, recomendam um período curto de 14 dias e um longo de 84 dias. A ADA ${ }^{6,148}$ sugere períodos experimentais que podem variar entre 7-10, 21-35 e 60-80 dias. Observamos que na literatura não existe um consenso entre os autores, quanto aos períodos de avaliação, TORNECK $^{167,168}$ e PHILLIPS ${ }^{121}$ utilizaram um período de 60 dias, HOLLAND et al. ${ }^{71,75,77}$ optaram por períodos de 7 e 30 dias, outros empregaram períodos que variam de 7 a 180 dias (OLSSON; SLIMKOWSKI; LANGELAND $^{116}$; ORSTAVIK e MJÖR ${ }^{117}$; FERRAZ et al. ${ }^{51}$; ECONOMIDES et al. ${ }^{44}$; KOLOKORIS et al. ${ }^{89,90}$; ZMENER; GLUGLIELMOTTI;

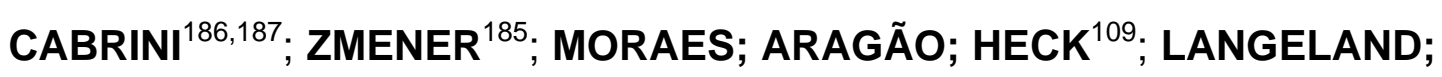
OLSSON; PASCON ${ }^{94}$ ). Empregamos neste estudo períodos experimentais 
de 15, 30 e 60 dias, baseados no estudo de MORETON et al. ${ }^{110}$. Ao final do trabalho, sentimos falta de um período experimental inicial mais curto, de sete dias, assim conseguiríamos comparar com mais detalhes a evolução do quadro reacional frente aos materiais em teste e o processo de reparo. $\operatorname{cosTA}^{35}$ (2001) recomendou períodos experimentais de 7, 15, 30 e 60 dias, que foram recentemente utilizados por YALTIRIK et al. ${ }^{182}$, em 2004, como períodos intermediários de avaliação. Vale a pena ressaltar, a observação feita por MORETTON et al. ${ }^{110}$ (2000), que um mês de vida para o rato equivale a aproximadamente 30 meses para o humano, portanto, se considerarmos um período de vida de três anos para o rato, comparando com o período de vida do humano equivale a 90 anos.

Antes do processamento histotécnico, durante a macroscopia, os tubos de polietileno foram retirados como descrito no capítulo de Material e Métodos. Este é um passo muito importante do trabalho, pois pouco cuidado neste momento pode causar o insucesso. Descobrimos quatro maneiras de retirar o tubo de polietileno do tecido:

1. Deixar $24 \mathrm{~h}$ na água ou álcool $70 \%$ e removê-lo antes de passar no histotécnico. Desta forma houve dificuldades pelo fato de o tecido vir aderido às extremidades do tubo.

2. Passar as peças pelo histotécnico para posterior remoção dos tubos. A retirada ficou facilitada, mas tivemos que incisar o tubo de ponta a ponta para conseguir removê-lo, danificando muito a peça, ficando levantada uma capa (tipo envelope), que depois foi preenchida com parafina na inclusão.

3. Para remoção do tubo, a peça foi cortada ao meio, e em seguida foram puxadas as partes cortadas do tubo. Para puxar, grande quantidade de tecido, lateral ao tubo, foi danificada, mas as extremidades pareciam preservadas, ficando com a forma do tubo. $\mathrm{Na}$ inclusão as partes da peça foram unidas tentando deixá-las na posição original. 
4. Os tubos são removidos depois da inclusão, durante o corte dos blocos pelo micrótomo. Talvez esta seja a melhor maneira pela maior preservação do tecido em contato com os materiais, pois a separação dos tecidos, agora mais consistentes, do tubo e dos cimentos é facilitada. Mas se tratando de um cimento muito duro, o fio da navalha é perdido facilmente antes mesmo de chegar a uma profundidade adequada para remoção do tubo. O próprio tubo também danifica a navalha. Acreditamos que para cimentos endodônticos mais maleáveis esta técnica possa ser empregada.

OLSSON; SLIWKOWSKI; LANGELAND ${ }^{116}$ (1981) salientam que os tubos com o material devem ser cortados in situ, justificando que se forem removidos antes dos cortes microscópicos, pode ser removida também a interface tecidual mais importante adjacente ao implante. Segundo as recomendações da ADA $^{7}$, quando os tubos conterem material duro e insolúvel, que pode danificar a lâmina do micrótomo, o espécime deve ser primeiramente fixado e então dividido em partes iguais no centro e em angulo de $90^{\circ}$ em relação ao tubo. O tubo dividido, deve então ser cuidadosamente removido de ambos os lados para reduzir o dano à área de interface. Os dois corpos podem ser preparados de forma padrão e avaliados juntos. Deve-se considerar que qualquer técnica envolvendo a remoção do implante antes dos cortes microscópicos, também poderá remover quantidade desconhecida de tecido aderido, impedindo a análise da interface material/tecido.

No entanto, optamos pela retirada do tubo após fixação, durante a macroscopia, por acreditar ser a melhor maneira para nosso estudo, para depois dar seqüência ao processamento histológico, técnica também realizada por TRINDADE; OLIVEIRA; FIGUEIREDO ${ }^{170}$ (2003). Neste caso, para atingir um bom resultado todo cuidado é pouco, principalmente na hora da incisão, que deve ser firme para não precisar repassar a lâmina, e também no deslocamento do tecido aderido ao material na extremidade do tubo, que deve ser separado com cautela do material testado. 
Os cortes microscópicos dos blocos de parafina foram de $5 \mu \mathrm{m}$ orientados no sentido do longo eixo do tubo e de seu lúmen, como recomendado pela ADA $^{7}$.

As reações teciduais foram avaliadas tanto quantitativa/subjetiva quanto qualitativa. De acordo com LEONARDO ${ }^{97}$ (1992), MOLLOY et al. ${ }^{108}$ (1992), CAMARGO ${ }^{27}$ (1993), BERBERT e CONSOLARO ${ }^{15}$ (1994), VALERA $^{173}$ (1995), as análises quantitativa/subjetiva dos fenômenos inflamatórios, fenômenos reparatórios e reações correlatas, desde que efetuadas por observadores calibrados, determinam resultados confiáveis para serem utilizados na avaliação dos cimentos testados.

\subsubsection{DOS CIMENTOS EMPREGADOS}

\subsubsection{A escolha do ProRoot MTA e MTA-Angelus}

A escolha do Agregado Trióxido Mineral (MTA) foi devido aos estudos sobre sua capacidade seladora, quando comparado a outros materiais, seja após a utilização de corantes ou mesmo penetração de bactérias, tem se mostrado o mais efetivo.

Diversas pesquisas têm demonstrado a excelente capacidade seladora marginal do MTA como material selador em perfurações radiculares $^{26,96}$; como material selador em perfurações de furca ${ }^{115}$; como material retrobturador em cirurgias parendodônticas ${ }^{9,13,18,53,54,103,128,151,157,158,179}$; como barreira intracoronária prévia ao clareamento dental ${ }^{36,99}$; e como material selador coronário ${ }^{143}$ e provisório ${ }^{14}$.

Essa capacidade seladora exibida pelo MTA provavelmente devese à sua natureza hidrofílica e suave expansão quando é manipulado em ambiente úmido $^{163}$ prevenindo a microinfiltração bacteriana ${ }^{4}$ e a infiltração de endotoxinas $^{151}$. Interessante notar que o MTA, mesmo quando colocado experimentalmente em cavidades retrógradas contaminadas com sangue, demonstrou excelente capacidade seladora, pois a infiltração marginal ocorrida na interface material/parede dentinária foi mínima ${ }^{158}$. Por possuir 
esta importante característica, o MTA tem muito a contribuir para os procedimentos cirúrgicos, tornando-se o material de escolha.

Nesta pesquisa, foi utilizado o ProRoot MTA na cor branca, fórmula atualmente comercializada pela Dentsply. Este produto não é encontrado no mercado nacional, tornando-se necessária sua importação para o uso e pesquisa, agregando maior valor ao material, que já possui um alto custo. É importante salientar que o ProRoot MTA utilizado nesta pesquisa, bem como para o projeto piloto foi cedido pela empresa DentsplyMéxico.

Visando o mercado odontológico nacional, sabendo da dificuldade em se conseguir o produto importado, a Angelus*, baseando-se nas pesquisas comparativas entre o MTA e o cimento Portland, desenvolveu o MTA brasileiro. Com o nome de MTA-Angelus, o produto foi lançado comercialmente em 2001 e, desde então, é vendido por menor valor. A cor do MTA-Angelus é cinza e muitos trabalhos mostraram que ele apresenta as mesmas propriedades do ProRoot MTA.

Em 2003, a empresa Angelus* nos enviou amostras para ensaio de dois tipos de agregado de trióxido mineral, o MTA Branco com sulfato de bário e o MTA Branco com óxido de bismuto (Figura 2). Com isso, foi intenção deste estudo avaliar a biocompatibilidade desses novos produtos, pois não sabíamos se a mudança de cor, ou o acréscimo das substâncias radiopacificadoras, poderiam alterar suas propriedades.

Em janeiro de 2004, a Angelus* lançou o "MTA Branco", contendo $80 \%$ de cimento Portland e $20 \%$ de óxido de bismuto, de cor branca.

A retirada do sulfato de cálcio da composição química do MTA, foi outra inovação feita pela empresa, em 2003, reduzindo o tempo de endurecimento para 15 minutos $^{91}$.

\footnotetext{
*Soluções em Odontologia, Londrina, Paraná, Brasil.
} 
Encontram-se na literatura pesquisas que avaliaram as propriedades do MTA de cor branca, outras o compararam com o de cor cinza. HOLLAND et al. ${ }^{78}$ (2002) avaliaram a reação do tecido conjuntivo de ratos a tubos de dentina, preenchidos com MTA branco (ProRoot MTA) e observaram os mesmos resultados obtidos com o MTA cinza, concluindo que o mecanismo de ação dos materiais é igual. FARACO Jr.; HOLLAND ${ }^{50}$ (2001) encontraram melhores resultados para o MTA cinza, quando este foi comparado o MTA branco em capeamentos pulpares em dentes de cães. Entretanto, CHAKMAKCHI et al. ${ }^{30}$ (2003) comparando a capacidade de selamento do MTA cinza e branco com o cimento Portland, em perfurações de furca de molares humanos extraídos, encontraram apenas diferença entre os grupos do MTA branco e cimento Portland, não havendo diferença entre os grupos do MTA branco e cinza. DIAMANTI et al. ${ }^{39}$ (2003) analisando a composição química, $\mathrm{pH}$ e as características da superfície do MTA cinza e do MTA branco (ProRoot MTA) demonstraram que ambos são iguais, porém com algumas diferenças na sua composição, o óxido de ferro $\left(\mathrm{Fe}_{2} \mathrm{O}_{3}\right)$, ausente no MTA branco e o sulfato de cálcio $\left(\mathrm{CaSO}_{4}\right)$, ausente no MTA cinza, concluindo que o MTA cinza e branco (ProRoot MTA) são cimentos Portland com alto $\mathrm{pH}$ e com superfície rugosa quando tomam presa. FERRIS; BAUMGARTNER ${ }^{52}$ (2004) avaliaram a capacidade de selamento, em perfurações de furca, do MTA cinza (fórmula original) e MTA branco (novo material), em molares humanos extraídos. Utilizaram um modelo experimental para infiltração de bactérias anaeróbicas, verificando que ambos os materiais se comportaram de forma idêntica na prevenção da infiltração do Fusobacterium nucleatum.

Os relatos descritos anteriormente confirmam a semelhança entre os materiais, e a escolha dependerá do local de aplicação, onde a estética estará envolvida. Exemplos de locais onde o cimento de cor branca pode ser empregado, são em perfurações de dentes anteriores com limite cervical e vestibular, pulpotomias e na proteção pulpar direta ${ }^{91,112}$. 


\subsubsection{A escolha do Cimento Portland branco não estrutural}

O cimento Portland foi utilizado neste trabalho devido à semelhança com o MTA (WUCHERPFENNING; GREEN ${ }^{180}$, 1999, ESTRELA et al. ${ }^{48}$, 2000) e por ser seu principal constituinte (75\% no ProRoot MTA ${ }^{124}$ e $80 \%$ no MTA-Angelus ${ }^{91,112}$ ).

O cimento Portland branco é classificado em dois subtipos: cimento Portland estrutural e não estrutural. Nesta pesquisa, foi utilizado o cimento Portland branco não estrutural, rico em materiais carbonáticos, ou rochas moídas, que apresentam carbonato de cálcio em sua constituição, como o próprio calcário. Tal adição serve para tornar os concretos e argamassas mais trabalháveis, porque os grãos ou partículas desses materiais moídos têm dimensões adequadas para se alojar entre os grãos ou partículas dos demais componentes do cimento, funcionando como um verdadeiro lubrificante. Quando presentes no cimento, são conhecidos como fíler calcário*. O cimento Portland Branco é empregado no rejuntamento de azulejos e na fabricação de ladrilhos hidráulicos, ou seja, em aplicações não estruturais. Segundo BERNABÉ; HOLLAND ${ }^{17}$ (2004), existem ainda mais tipos de cimentos, porém estes não se relacionam com nosso interesse na pesquisa. A cor cinza do clínquer do cimento Portland comum é devido à presença de ferro e manganês, mas diminuindo o teor de ferro do clínquer, pode-se produzir cimentos de cores claras, além do que, na fabricação do cimento branco, utiliza-se, como matéria prima, argila e rochas carbonatadas sem ferro.

MENEZES et al. ${ }^{105}$ (2004) compararam o cimento Portland branco não estrutural, cimento Portland cinza, ProRoot MTA e MTA-Angelus (ambos de cor cinza), em pulpotomias de dentes de cães, observando boa capacidade de formação de tecido mineralizado e preservação do tecido pulpar subjacente, concluindo não haver diferença na utilização de um ou outro material e que a cor não interfere nos resultados.

\footnotetext{
* ASSOCIAÇÃO BRASILEIRA DO CIMENTO PORTLAND. Guia de utilização do cimento Portland. 7.ed. São Paulo, 2002. 28p. (BT-106)
} 
Em nossa pesquisa, adicionamos $20 \%$ de óxido de bismuto ao cimento Portland branco, com o propósito de lhe conferir radiopacidade, baseados na proporção de óxido de bismuto do MTA-Angelus e do ProRoot MTA. Isto se deve, pelo fato do cimento Portland apresentar radiopacidade inferior ao $\mathrm{MTA}^{176}$ e, lembrando do trabalho de ESTRELA et al. ${ }^{48}$ (2000), onde mostraram que a única diferença entre o MTA e o cimento Portland é o óxido de bismuto, adicionado ao MTA para the conferir radiopacidade. TRINDADE e FIGUEIREDO ${ }^{169}$ (2002) acrescentaram substâncias radiopacificadoras, em forma líquida, ao MTA e cimento Portland. Os autores analisaram os elementos químicos presentes nesses materiais, e constataram uma grande semelhança, exceção feita ao óxido de bismuto contido no MTA e o potássio, contido no cimento Portland, concordando com GUARIENTI; OSINAGA; FIGUEIREDO ${ }^{61}$ (2002), que, analisaram a composição química do MTA e do cimento Portland, confirmando a presença de óxido de bismuto no MTA e de molibdênio no cimento Portland. BERNABÉ; HOLLAND ${ }^{17}$ (2004) salientaram que o óxido de bismuto apresenta um alto peso molecular e segundo SILVA HERZOG-FLORES et al. $^{140}$ (2000), é um material insolúvel em água, possivelmente esse fato, ocasione demora na reabsorção, quando extravasado aos tecidos periodontais. TRINDADE; OLIVEIRA; FIGUEIREDO ${ }^{170}$ (2003) avaliaram a resposta do tecido subcutâneo de ratos frente ao implante de tubos de polietileno contendo MTA, cimento Portland e cimento Portland acrescido de $20 \%$ e $30 \%$ de óxido de bismuto. Após períodos experimentais de 7, 15 e 30 dias, os resultados mostraram não haver diferença entre as respostas teciduais, para os diferentes materiais testados, nos três períodos. Os autores sugerem aos fabricantes o acréscimo de maior quantidade de óxido de bismuto ao MTA, pois não interfere em sua biocompatibilidade, e assim facilitaria a sua visualização radiográfica naqueles procedimentos em que a espessura do material não é suficiente para destacar sua presença. 


\subsubsection{A escolha da guta-percha como controle}

A ADA $^{6,7}$ e a ISO ${ }^{82,147}$ recomendam que nos testes de implantação subcutânea, a lateral do tubo de polietileno sirva como controle. Encontramos trabalhos na literatura que utilizaram como controle um tubo vazio (ECONOMIDES et al. ${ }^{44}$, 1995; KOLOKOURIS et al. ${ }^{89}$, 1996; KOLOKOURIS et al. ${ }^{90}$, 1998; HOLLAND et al. ${ }^{71}$, 1999; HOLLAND et al. ${ }^{77}$, 2002; KAPLAN et al. ${ }^{84}$, 2003), outros usaram um tubo sólido de silicone (ZMENER et al. ${ }^{186}, 1988$ e ZMENER $\left.{ }^{185}, 2004\right)$.

Em nosso estudo, poderíamos ter utilizado as laterais do tubo como controle, mas preferimos a guta-percha, por ser a substância mais utilizada na obturação dos canais radiculares. O seu uso se deve pela facilidade de seu emprego e por ser bem tolerada pelos tecidos vivos $^{19,69,80,92,98,134,146,178}$. 


\subsection{DOS RESULTADOS}

\subsubsection{Reação tecidual frente aos materiais implantados}

Biocompatibilidade pode ser definida como a capacidade de um material exercer funções específicas quando aplicado em contato com tecidos vivos de determinado hospedeiro, sem contudo causar danos ou prejuízos ao mesmo (COSTA $\left.{ }^{34}, 2001\right)$.

Os materiais endodônticos, além de passarem por testes físicos e químicos, devem ter sua biocompatibilidade investigada (TORABINEJAD; PITT FORD ${ }^{156}$, 1996). Neste sentido, esta pesquisa foi realizada.

Todos os materiais testados neste estudo, apresentaram comportamento biológico semelhante, entretanto, notamos durante a análise microscópica uma reação melhor do tecido frente ao grupo controle (gutapercha). Podemos destacar pequenas diferenças entre os cimentos experimentais pela análise descritiva e por meio das médias dos escores.

Nos períodos experimentais de nossa investigação, a resposta do tecido conjuntivo subcutâneo foi de uma inflamação crônica, determinada pelos materiais testados, que a princípio era mais intensa, e com o passar do tempo tornou-se mais discreta, sinalizando a biocompatibilidade dos materiais.

Os pontos histológicos fundamentais da inflamação crônica são: 1) infiltração por células mononucleares, principalmente macrófagos, linfócitos e plasmócitos; 2) proliferação de fibroblastos e, em muitos casos, de pequenos vasos sanguíneos; 3) aumento do tecido conjuntivo (fibrose); 4) destruição tissular (CONTRAN; KUMAR; ROBBINS ${ }^{33}$, 1991). Foram observadas em todos os grupos, nos três períodos experimentais, a presença destas características.

Como referência da reação tecidual tivemos o lado controle (gutapercha), que apesar ter ficado voltada para o lado onde ocorreu o maior trauma cirúrgico, aos 15 dias já se encontrava envolta por uma cápsula fibrosa, que na verdade envolvia todo o tubo. A cápsula apresentava-se 
pouco densa e com fibroblastos jovens, mostrando-se em processo evolutivo de maturação. Macrófagos, linfócitos e células gigantes multinucleadas do tipo corpo estranho também foram vistos, caracterizando uma reação inflamatória granulomatosa ou do tipo corpo estranho, com a formação de verdadeiros granulomas.

Segundo CONSOLARO ${ }^{32}$ (1998) em alguns granulomas não há envolvimento de células linfóides e de qualquer fenômeno imunopatológico pois o agente indutor não tem poder imunogênico, geralmente são agentes desprovidos de componentes de natureza protéica: carvão, vidro, metais, cimentos e pastas obturadoras, guta-percha e fios de sutura. Estes agentes, por isso, podem ser genericamente chamados de corpos estranhos, não têm propriedade antigênica, e o granuloma induzido apresenta-se constituído basicamente por macrófagos e células derivadas, também indutoras, via citocinas, da formação de uma cápsula fibrosa periférica ao processo. Quando estas condições estão presentes, o granuloma pode ser denominado como granuloma do tipo corpo estranho, granuloma não imunogênico ou ainda granuloma de baixa renovação celular.

Portanto, foi o que observamos neste estudo, não só com a gutapercha, mas todos materiais empregados neste estudo atuaram como corpo estranho induzindo a uma inflamação crônica granulomatosa.

O autor salienta ainda, que a presença de um granuloma indica persistência local do agente agressor, e que quando consegue eliminá-lo por ação de suas células e substâncias, ou com a ajuda de medicamentos, sua tendência natural consiste na substituição gradativa de sua estrutura por tecido de granulação e conseqüente reparo da área.

O ProRoot MTA, o MTA Branco com os dois tipos de radiopacificadores e o cimento Portland apresentaram respostas teciduais semelhantes nos três períodos avaliados, mas quando comparados ao grupo controle, observamos que o infiltrado inflamatório foi mais intenso ao longo do tempo. 
Apesar de os cimentos testados não apresentarem diferença estatística significante, podemos salientar algumas de suas principais características nos períodos avaliados, baseados nas médias dos escores.

Aos 15 dias a guta-percha apresentou maior intensidade inflamatória (média=2,17), talvez por ter ficado voltada para área de maior trauma como explicado anteriormente, já o ProRoot MTA apresentou a menor média $(1,77)$. Os agregados de trióxido mineral da Angelus, com óxido de bismuto ou com sulfato de bário, tiveram médias iguais de intensidade inflamatória $(1,88)$, enquanto o cimento Portland provocou resposta inflamatória com segunda maior intensidade (média=2,0).

Quanto à proliferação fibroblástica, a guta-percha também se destacou (média=2,26), seguido pelo grupo do MTA Branco com óxido de bismuto (média=2,11), e os outros grupos tiveram médias iguais $(1,88)$. A neoformação de vasos foi moderada a discreta para todos os grupos (média de 1,55 a 2,0), exceto para o grupo do cimento Portland que apresentou discreta proliferação angioblástica (média=1,33). Da mesma forma a densidade do fibrosamento, moderada para todos os grupos (média de 1,55 a 2,0), exceto para o grupo controle que se mostrou discreta (média=1,35).

No período de 30 dias, o fibrosamento em volta dos materiais tornou-se mais denso, a disposição de fibras colágenas estavam organizadas em feixes permeadas por fibroblastos. Curiosamente, em todos os grupos a média da intensidade inflamatória foi maior do que no período inicial, sendo o cimento Portland responsável pela maior média $(2,2)$. O grupo da guta-percha apresentou menor intensidade inflamatória (média=1,89) e o cimento Portland a maior $(2,2)$. A proliferação fibroblástica manteve-se moderada para todos os grupos, e a neoformação de vasos também, menos para os grupos do cimento Portland e o controle. Apesar dos tecidos responderem melhor ao grupo controle, apresentando menor intensidade de inflamação, teve a menor média de densidade do fibrosamento (1,59), já o ProRoot MTA obteve a maior média $(2,0)$.

No período mais avançado, de 60 dias, os eventos teciduais mostraram, em geral, uma diminuição da intensidade inflamatória. O lado 
controle apresentou uma densa cápsula fibrosa, com poucos fibroblastos, e reação inflamatória de intensidade discreta (média=1,40), sendo em alguns espécimes ausente (Figuras 16K, 16L, 17K e 17L). A inflamação crônica persistiu junto aos materiais testados, com intensidade moderada, onde 0 cimento Portland obteve maior média $(2,10)$ havendo diferença estatística com o grupo controle, quando realizadas comparações individuais (Teste de Dunn - Tabela 4). A proliferação fibroblástica diminui em todos os grupos, principalmente para o grupo controle (média=1,37), que teve também a menor média de proliferação angioblástica $(1,32)$. Os espécimes do grupo do cimento Portland foram os que apresentaram a maior neoformação de vasos sanguíneos (média=2,0), inclusive quando o fenômeno foi comparado com os períodos iniciais, havendo diferença estatística significante entre os períodos de 30 e 60 dias.

FRANCO $^{55}$ apud BERNABÉ e HOLLAND ${ }^{17}$ (2004) obteve uma resposta tecidual diferente no período inicial. O autor estudou a reação do tecido da área de filtro de dez ratos ao implante de tubos de polietileno preenchidos com MTA (ProRoot MTA) e cimento Portland (Cimento Zebu). Os resultados demonstraram que a resposta tecidual em duas semanas foi similar para ambos materiais, sendo caracterizada por reação inflamatória aguda, sensivelmente mais branda pra o ProRoot MTA, com predominância de tecido fibroso, fibrina e vasos congestos, presença de fibroblastos e macrófagos, além da presença de neutrófilos para o cimento Portland.

Já no período mais longo, 12 semanas, demonstrou-se uma tendência a cronificação para ambos os cimentos, com a presença de tecido fibroso, fibroblastos e macrófagos, além da presença de vasos congestos, linfócitos e células gigantes em alguns espécimes do cimento Portland.

Quando analisamos cada material em relação aos três períodos experimentais, houve diferença estatística significante para o grupo controle quanto a intensidade inflamatória, proliferação fibroblástica e densidade do fibrosamento. Realizando comparações individuais, a diferença estatística foi significante para a intensidade inflamatória, proliferação fibroblástica e densidade do fibrosamento entre os períodos de 15 e 60 dias, e 30 e 60 
dias. Quanto à proliferação angioblástica, houve diferença estatística significante para o cimento Portland, e as comparações individuais mostraram a diferença entre 30 e 60 dias.

Comparando globalmente todos os grupos entre si em cada período experimental, e individualmente cada grupo nos diferentes períodos podemos chegar as seguintes observações em relação aos fenômenos analisados.

O cimento Portland teve as maiores médias de intensidade de inflamação nos três períodos ( 15 dias $=2,00,30$ dias $=2,20$ e 60 dias $=$ 2,10 ) e o ProRoot MTA as menores médias (15 dias $=1,77,30$ dias $=2,20$ e 60 dias = 1,70). Quanto ao MTA Branco com óxido de bismuto ou com sulfato de bário apresentaram médias semelhantes. Curiosamente, em todos os grupos a média da intensidade inflamatória foi maior no período de 30 dias, e as médias do período de 60 dias foram maiores que as iniciais para os grupos III e IV (MTA Branco com sulfato de bário e cimento Portland) (Tabela 4).

A proliferação fibroblástica foi diminuindo com o passar do tempo em todos os grupos, sendo que o MTA Branco com óxido de bismuto e o com sulfato de bário obtiveram as maiores médias nos períodos avaliados (Tabela 5).

Pode-se dizer que houve um aumento na proliferação angioblástica nos períodos experimentais mais longos. Principalmente para o cimento Portland, havendo diferença estatística entre os períodos de 30 e 60 dias.

Nossos resultados mostram que a densidade do fibrosamento aumentou com o tempo, tornando a cápsula fibrosa mais organizada, com menor número de fibroblastos entre as fibras, corroborando com os trabalhos descritos na literatura $44,84,108,111,117$. O MTA Branco com óxido de bismuto destacou-se pelo constante aumento e maior média de densidade no período de 60 dias (15 dias $=1,77,30$ dias $=1,80$ e 60 dias $=2,20$ ). 0 MTA Branco com sulfato de bário e o ProRoot MTA também tiveram médias altas nos três períodos experimentais, enquanto que o cimento Portland 
obteve as médias mais baixas (15 dias $=1,55,30$ dias $=1,70$ e 60 dias $=$ 1,90).

Os macrófagos, e muitos deles com partículas no citoplasma, foram as células predominantes em todos os grupos, como também a presença discreta, mas constante de células gigantes multinucleadas tipo corpo estranho. A formação de granulomas do tipo corpo estranho é um fenômeno inerente à reação inflamatória crônica, sendo sua presença marcante frente aos cimentos estudados em todos os períodos.

Os materiais mostraram-se microscopicamente na forma granular, na grande maioria das vezes no nível da extremidade do tubo. A presença de partículas no interior do citoplasma de macrófagos e CGMIs, constante em todos os tempos de avaliação, demonstram uma solubilização superficial dos materiais testados no período inicial. Isto pode ter acontecido devido os materiais terem sido inseridos nos tecidos recém-espatulados, ou talvez por um mínimo extravasamento.

Concordamos com outros pesquisadores ${ }^{111,117,130}$, os quais relatam que a observação da resposta do tecido conjuntivo mostra variação para um mesmo material de um implante para o outro, assim como do sítio de um implante para outro no mesmo animal. Portanto, este método pode não discernir bem entre materiais com pequenas diferenças de toxicidade.

Segundo HOLLAND et al. ${ }^{71,76}$, o mecanismo de ação do MTA é semelhante ao do hidróxido de cálcio. Os autores implantaram no tecido subcutâneo de ratos tubos de dentina preenchidos com hidróxido de cálcio ou MTA. As peças foram removidas após 7 e 30 dias e processadas sem descalcificar. Assim, cortes obtidos em um micrótomo de tecido duro foram analisados com auxílio de luz polarizada e coloração de Von Kossa para sais de cálcio. Notaram que, com o hidróxido de cálcio, havia formação de granulações de calcita, birrefringentes à luz polarizada, junto à luz do tubo. Abaixo dessas granulações formou-se uma ponte de tecido mineralizado Von Kossa positiva. Além disso, foi também observada a presença de granulações de calcita, birrefringentes à luz polarizada, no interior dos túbulos dentinários. Com o MTA o mesmo foi observado, notando-se apenas 
que o número de granulações de calcita era um pouco menor que o observado com o hidróxido de cálcio e que essas granulações estavam em contato com o material estudado, o que não ocorria com o hidróxido de cálcio. HOLLAND ${ }^{66}$, em 1971, relatou que essas granulações formam-se através da reação do cálcio do hidróxido de cálcio com o gás carbônico do tecido. As mesmas granulações foram descritas por SEUX et al. ${ }^{136}$ (1991) em experimentação in vitro. Além disso, esses autores notaram acúmulo de fibronectina, uma glicoproteína, em íntimo contato com esses cristais de calcita, em meio de cultura de células. SEUX et al. ${ }^{136}$ concluíram que seus achados constituíram forte evidência do papel das granulações de calcita e da fibronectina como um ponto de partida inicial na formação de uma barreira de tecido mineralizado. Portanto o estudo de HOLLAND et al. ${ }^{71}$ (1999), mostrou similaridade de resultados entre o hidróxido de cálcio e o MTA. Ambos materiais determinam a formação de granulações de calcita e uma ponte de tecido mineralizado subjacente, evidenciando que 0 mecanismo de ação do MTA seria o mesmo do hidróxido de cálcio. O óxido de cálcio do pó do MTA, ao realizar-se a preparação da pasta com água, seria convertido em hidróxido de cálcio. Este, por sua vez, em contato com os fluídos tissulares se dissociaria em íons cálcio e hidroxila. Os íons cálcio, reagindo com o gás carbônico dos tecidos, dariam origem às granulações de calcita. Junto a essas granulações haveria acúmulo de fibronectina, que pertence a um grupo de moléculas de adesão de substrato, responsáveis pela migração, adesão e diferenciação celular, sendo produzida por fibroblastos, macrófagos e células endoteliais (TROWBRIDGE e EMLING ${ }^{171}$, 1997) Na seqüência tem-se formação de uma ponte de tecido mineralizado.

Resultados semelhantes foram encontrados por HOLLAND et al. $^{75}$ (2001) quando implantaram tubos de dentina preenchidos com MTA, cimento Portland e hidróxido de cálcio no tecido subcutâneo de ratos. Em mais dois trabalhos, utilizando a mesma metodologia, HOLLAND et al. ${ }^{77}$ (2002) e HOLLAND et al. ${ }^{78}$ (2002) observaram as granulações de calcita e a formação de tecido mineralizado junto ao MTA, seja o de cor branca ou cinza. 
Como descrito acima, HOLLAND et al. ${ }^{75,77,78}$ demonstraram excelentes resultados, onde foi visualizado tecido mineralizado, entretanto, deve-se observar a metodologia empregada. A coloração Von Kossa é específica para sais de cálcio, deixando-os escuros quando analisados microscopicamente, e se for utilizada luz polarizada, estes se apresentam birrefringentes, sendo considerados Von Kossa positivos. O achado destas granulações de calcita, dentro dos túbulos dentinários e próximo ao material, na abertura do tubo, pode ser devido aos íons cálcio, liberados pelo material, quando misturado com água ou em contato com os fluidos tissulares. DUARTE et al. ${ }^{42}$, em 2003, avaliaram o pH e a liberação de íons de cálcio do ProRoot MTA e MTA-Angelus, e mesmo após 168 horas, ambos materiais continuavam a liberar os íons.

Em nosso trabalho utilizamos a coloração de Hematoxilina e Eosina, e não foi possível observar essas calcificações, nem sinais sugestivos destas, resultados semelhantes foram encontrados por TRINDADE; OLIVEIRA; FIGUEIREDO ${ }^{170}$ (2003).

Apesar de terem feito também H.E. em seus estudos, HOLLAND et al. ${ }^{75,77,78}$ dão preferência em descrever os resultados achados com a coloração Von Kossa. Quando relatam os achados, vistos nas lâminas coradas por H.E., aos sete dias, mostram algumas áreas irregulares basofílicas correspondendo às áreas altamente Von Kossa positiva observadas nos cortes não desmineralizados. Essas áreas exibiam a inclusão de núcleos celulares em sua massa. Envolvendo esta área, havia inicialmente uma reação inflamatória crônica discreta ou moderada no tecido conjuntivo e algumas células gigantes. Aos 30 dias, o tecido conjuntivo ao redor das áreas calcificadas era fibroso, com algumas células gigantes e uma discreta reação inflamatória. Nesta coloração não foi destacada, provavelmente também não visualizada, a presença de calcificação.

MOTTA et al. ${ }^{111}$ (2003) analisaram as reações morfológicas teciduais do tecido subcutâneo de ratos, frente ao implante de tubos de polietileno contendo MTA e pasta de hidróxido de cálcio (Calen). Relataram 
que também não encontraram traços de cristais que significassem calcificação no tecido conjuntivo em contato com o MTA. Os autores explicam que tal acontecimento poderia ser devido à localização do corte ou ao material que é confeccionado o tubo, o que não favorecia áreas de calcificação, como é o caso do tubo confeccionado por dentina, sugerido por HOLLAND et al. ${ }^{68}$, em 1973. Entretanto, observaram, no período de 30 dias, a presença de áreas positivas à técnica de Von Kossa, significando formação de tecido calcificado em alguns espécimes contendo hidróxido de cálcio. YALTIRIK et al. ${ }^{182}$ (2004) também observaram calcificações distróficas nos períodos experimentais de 60 e 90 dias, vistas pela coloração de Von Kossa.

MORETTON et al. ${ }^{110}$ (2000) compararam a biocompatibilidade e o potencial osteocondutivo e osteoindutivo do MTA e do cimento Super EBA, após implantes subcutâneos e intra-ósseos em ratos. A reação tecidual foi avaliada aos 15, 30 e 60 dias após os implantes. Os implantes subcutâneos de MTA induziram, inicialmente, reações severas como necrose por coagulação, calcificação distrófica e áreas de fibrose. O infiltrado inflamatório era constituído de macrófagos, linfócitos e células plasmáticas, estando presentes, também, células gigantes tipo corpo estranho. Com o tempo, a reação tornou-se moderada. Osteogênese não foi observada com nenhum dos materiais nos implantes subcutâneos, indicando que os materiais não foram osteoindutores. As reações teciduais aos implantes intra-ósseos, para ambos os materiais, foram menos intensas do que para os implantes subcutâneos. Ocorreu osteogênese associada a esses implantes, indicando que ambos os materiais são osteocondutores. Os dois materiais foram considerados biocompatíveis. O Super EBA foi considerado de nível 2, isto é, materiais como guta-percha e óxido de zinco, que provocam uma resposta inicial de leve a moderada, que diminui com o tempo. Já o MTA, foi considerado de nível 3, assim como o hidróxido de cálcio, ou seja, o material induz uma resposta inflamatória inicial de moderada a severa, incluindo respostas teciduais como formação de células gigantes do tipo corpo 
estranho, necrose coagulativa e calcificações distróficas e essa resposta diminui com o tempo.

Pela escala de biocompatibilidade sugerida por MORETTON et al. $^{110}$ (2000) os materiais testados no presente estudo são considerados de nível 3, concordando com os achados destes autores.

Em nossa opinião, o MTA cria condições favoráveis ao reparo, devido a sua biocompatibilidade, seu elevado $\mathrm{pH}$, o excelente selamento físico proporcionado, além de servir de matriz para neoformação tecidual. Por estas e outras propriedades químicas e biológicas, o organismo reage promovendo o processo de reparo.

Quanto aos radiopacificadores acrescentados ao MTA Branco (Angelus), o óxido de bismuto é o comumente utilizado em outras marcas comerciais, já o sulfato de bário é uma novidade no MTA. Neste estudo, de acordo com nossos resultados, ambos não interferiram na biocompatibilidade do material, discordando dos trabalhos de CATHERS; KAMINSKY; OSETEK ${ }^{29}$ (1984), que relatam que o sulfato de bário é um material não degradável que provavelmente tem propriedades tóxicas, e SMITH; LEEB; TORNEY ${ }^{142}$ (1984), que consideraram os íons de bário não biocompatíveis, visto que eles acharam reações de corpo estranho severas em contato com esse material.

Com relação ao cimento Portland, acrescido de óxido de bismuto, constatamos que, a reação do tecido subcutâneo não diferiu daquela induzida pelos outros cimentos. De fato, o experimento de SAIDON et al. ${ }^{132}$ (2003), comparando o efeito citotóxico in vitro com o ProRoot MTA, demonstrou que eles não são tóxicos e que o cimento Portland tem potencial para ser usado como cimento indutor de reparo mais barato. As pesquisas confirmam que o cimento Portland é a base do MTA, porém, isto não faz com que os clínicos o utilizem indiscriminadamente, pelo fato de ser mais barato que o MTA (BERNABÉ; HOLLAND ${ }^{17}$, 2004).

Sabendo que o MTA é composto basicamente de cimento Portland, estudos sobre este cimento, podem melhorar as propriedades do outro, como sugerido por MENEZES ${ }^{104}$ (2003), principalmente no que se diz 
respeito à adição de radiopacificadores e adição de aceleradores do tempo de presa, visando à aprovação do Ministério da Saúde para uso clínico.

Concordamos com BERNABÉ; HOLLAND ${ }^{17}$ (2004), de que não deve ser recomendada a utilização do cimento Portland em pacientes, por envolver princípios éticos e jurídicos, uma vez que há, no Ministério da Saúde, registro do MTA e não do cimento Portland, que é distribuído como material de construção civil. Mas acreditamos, que num futuro próximo, o custo do MTA vai ser muito menor, assim como é para o hidróxido de cálcio e o cimento Portland. Assim todas indicações e vantagens deste material estarão acessíveis, e ele se tornará uma realidade em todos os consultórios e órgãos públicos, favorecendo dentistas e pacientes. 


\section{CONCLUSÕES}




\section{CONCLUSÕES}

Diante dos resultados obtidos, e respeitando-se as limitações da metodologia empregada, é possível concluir que:

1 Os cimentos ProRoot MTA, MTA Branco (Angelus) com sulfato de bário ou óxido de bismuto e o Portland com óxido de bismuto mostraram resultados sem diferença estatisticamente significante nos períodos experimentais de 15, 30 e 60 dias;

2 Não se observou diferença entre o MTA Branco (Angelus) com óxido de bismuto ou com sulfato de bário. 


\section{ANEXOS}




\section{ANEXO 1}

\section{TABELA PARA ANESTESIA DE RATO}

INTRAMUSCULAR: (Face posterior da coxa, agulha: $13 \times 3,8$ )

MEDICAČÃO PRÉ-ANESTÉSICA (M.P.A): Quetamina $25 \mathrm{mg} / \mathrm{Kg}$ IM .

ANESTESIA: $\quad$ Xilazina $\quad 10 \mathrm{mg} / \mathrm{kg}$ ( IP ) associada à

Quetamina $25 \mathrm{mg} / \mathrm{kg}$ (IP) na mesma seringa.

Período latência (PL): 2-5 min.

Período hábil (PH): 40 min.

\begin{tabular}{|c|c|c|c|}
\hline \multirow{3}{*}{$\begin{array}{c}\text { Rato } \\
\text { Peso (g) }\end{array}$} & Relaxante Muscular (M.P.A) & \multicolumn{2}{|c|}{ ANESTESIA } \\
\hline & QUETAMINA & XILAZINA & QUETAMINA \\
\hline & $\begin{array}{c}\text { Francotar, Dopalen, Vetaset } \\
\text { ml. }\end{array}$ & $\begin{array}{l}\text { Anasedan, rompun } \\
\mathrm{ml} .\end{array}$ & $\begin{array}{c}\text { Francotar, Dopalen, Vetaset } \\
\text { ml. }\end{array}$ \\
\hline 100 & .025 & .050 & .025 \\
\hline 110 & .027 & .055 & .027 \\
\hline 120 & .030 & .060 & .030 \\
\hline 130 & .032 & .065 & .032 \\
\hline 140 & .035 & .070 & .035 \\
\hline 150 & .037 & .075 & .037 \\
\hline 160 & .040 & .080 & .040 \\
\hline 170 & .042 & .085 & .042 \\
\hline 180 & .045 & .090 & .045 \\
\hline 190 & .047 & .095 & .047 \\
\hline 200 & .050 & .100 & .050 \\
\hline 210 & .052 & .105 & .052 \\
\hline 220 & .055 & .110 & .055 \\
\hline 230 & .057 & .115 & .057 \\
\hline 240 & .060 & .120 & .060 \\
\hline 250 & .062 & .125 & .062 \\
\hline 260 & .065 & .130 & .065 \\
\hline 270 & .067 & .135 & .067 \\
\hline 280 & .070 & .140 & .070 \\
\hline 290 & .072 & .145 & .072 \\
\hline 300 & .075 & .150 & .075 \\
\hline 310 & .077 & .155 & .077 \\
\hline 320 & .080 & .160 & .080 \\
\hline 330 & .082 & .165 & .082 \\
\hline 340 & .085 & .170 & .085 \\
\hline 350 & .087 & .175 & .087 \\
\hline
\end{tabular}

Fonte: Manual para técnicos em bioterismo

Colégio Brasileiro de Experimentação Animal (COBEA)

BIOTÉRIO - FOB 


\section{ANEXO 2}

Quadro 1 - Ficha utilizada para registro das análises microscópicas das reações provocadas pelo cimento ProRoot MTA no período de 15 dias.

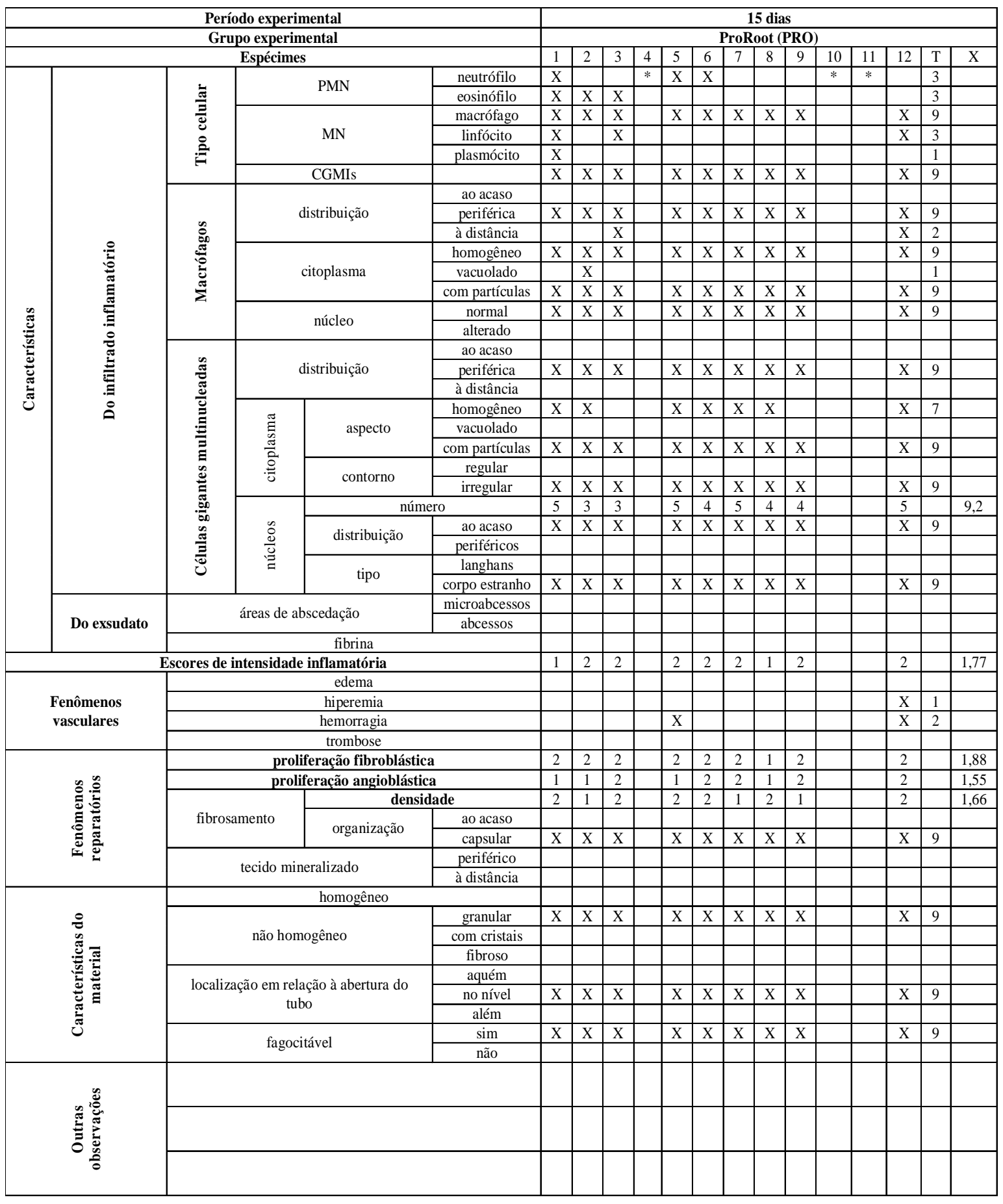

$\left.{ }^{\star}{ }^{\star}\right)$ os espécimes correspondentes não propiciaram condições para análise. 


\section{ANEXO 3}

Quadro 2 - Ficha utilizada para registro das análises microscópicas das reações provocadas pelo cimento ProRoot MTA no período de 30 dias.

\begin{tabular}{|c|c|c|c|c|c|c|c|c|c|c|c|c|c|c|c|c|c|c|c|}
\hline \multicolumn{6}{|c|}{ Período experimental } & \multicolumn{14}{|c|}{30 dias } \\
\hline \multicolumn{6}{|c|}{ Grupo experimental } & \multicolumn{14}{|c|}{ ProRoot (PRO) } \\
\hline \multicolumn{6}{|c|}{ Espécimes } & 1 & 2 & 3 & 4 & 5 & 6 & \begin{tabular}{|l|l}
7 \\
\end{tabular} & 8 & 9 & 10 & 11 & 12 & $\mathrm{~T}$ & $\mathrm{X}$ \\
\hline \multirow{30}{*}{ 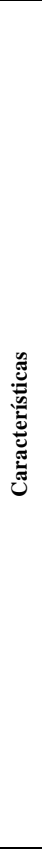 } & \multirow{27}{*}{ 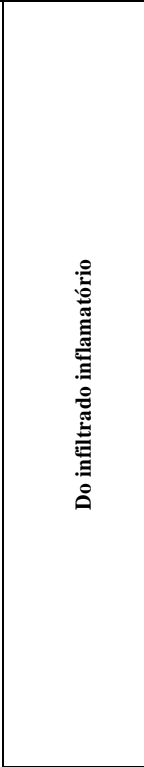 } & \multirow{6}{*}{ 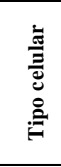 } & \multirow{2}{*}{\multicolumn{2}{|c|}{ PMN }} & neutrófilo & & & & * & & & & & $*$ & & & & & \\
\hline & & & & & eosinófilo & $\mathrm{X}$ & & & & $\mathrm{X}$ & & $\mathrm{X}$ & & & & $\mathrm{X}$ & $\mathrm{X}$ & 5 & \\
\hline & & & \multirow{4}{*}{\multicolumn{2}{|c|}{ MN }} & macrófago & $\mathrm{X}$ & $\mathrm{X}$ & $\mathrm{X}$ & & $\mathrm{X}$ & $\mathrm{X}$ & $\mathrm{X}$ & $\mathrm{X}$ & & $\mathrm{X}$ & $\mathrm{X}$ & $\mathrm{X}$ & 10 & \\
\hline & & & & & linfócito & $\mathrm{X}$ & $\mathrm{X}$ & $\mathrm{X}$ & & $\mathrm{X}$ & $\mathrm{X}$ & $\mathrm{X}$ & $\mathrm{X}$ & & $\mathrm{X}$ & $\mathrm{X}$ & $\mathrm{X}$ & 10 & \\
\hline & & & & & plasmócito & $\mathrm{X}$ & $\mathrm{X}$ & $\mathrm{X}$ & & & $\mathrm{X}$ & $\mathrm{X}$ & $\mathrm{X}$ & & $\mathrm{X}$ & $\mathrm{X}$ & $\mathrm{X}$ & 9 & \\
\hline & & & & & & $\mathrm{X}$ & $\mathrm{X}$ & $\mathrm{X}$ & & $\mathrm{X}$ & $\mathrm{X}$ & $\mathrm{X}$ & $\mathrm{X}$ & & $\mathrm{X}$ & $\mathrm{X}$ & $\mathrm{X}$ & 10 & \\
\hline & & & \multirow{3}{*}{\multicolumn{2}{|c|}{ distribuição }} & ao acaso & & & & & & & & & & & & & & \\
\hline & & & & & periférica & $\mathrm{X}$ & $\mathrm{X}$ & $\mathrm{X}$ & & $\mathrm{X}$ & $\mathrm{X}$ & $\mathrm{X}$ & $\mathrm{X}$ & & $\mathrm{X}$ & $\mathrm{X}$ & $\mathrm{X}$ & 10 & \\
\hline & & 品 & & & à distância & $\mathrm{X}$ & & $\mathrm{X}$ & & $\mathrm{X}$ & $\mathrm{X}$ & $\mathrm{X}$ & $\mathrm{X}$ & & $\mathrm{X}$ & $\mathrm{X}$ & $\mathrm{X}$ & 9 & \\
\hline & & :ँّ & & & homogêneo & $\mathrm{X}$ & & $\mathrm{X}$ & & $\mathrm{X}$ & $\mathrm{X}$ & $\mathrm{X}$ & $\mathrm{X}$ & & $\mathrm{X}$ & $\mathrm{X}$ & $\mathrm{X}$ & 9 & \\
\hline & & L & & citoplasma & vacuolado & & & & & & & & & & & & & & \\
\hline & & & & & com partículas & $\mathrm{X}$ & $\mathrm{X}$ & $\mathrm{X}$ & & $\mathrm{X}$ & $\mathrm{X}$ & $\mathrm{X}$ & $\mathrm{X}$ & & $\mathrm{X}$ & $\mathrm{X}$ & $\mathrm{X}$ & 10 & \\
\hline & & & & núcleo & normal & $\mathrm{X}$ & $\mathrm{X}$ & $\mathrm{X}$ & & $\mathrm{X}$ & $\mathrm{X}$ & $\mathrm{X}$ & $\mathrm{X}$ & & $\mathrm{X}$ & $\mathrm{X}$ & $\mathrm{X}$ & 10 & \\
\hline & & & & 1нucieo & alterado & & & & & & & & & & & & & & \\
\hline & & & & & ao acaso & & & & & & & & & & & & & & \\
\hline & & & & distribuição & periférica & $\mathrm{X}$ & $\mathrm{X}$ & $\mathrm{X}$ & & $\mathrm{X}$ & $\mathrm{X}$ & $\mathrm{X}$ & $\mathrm{X}$ & & $\mathrm{X}$ & $\mathrm{X}$ & $\mathrm{X}$ & 10 & \\
\hline & & $\bar{\pi}$ & & & à distância & & $\mathrm{X}$ & & & & & & & & & & & 1 & \\
\hline & & 气ू & & & homogêneo & $\mathrm{X}$ & $\mathrm{X}$ & $\mathrm{X}$ & & $\mathrm{X}$ & $\mathrm{X}$ & $\mathrm{X}$ & $\mathrm{X}$ & & $\mathrm{X}$ & $\mathrm{X}$ & $\mathrm{X}$ & 10 & \\
\hline & &.$\vec{\Xi}$ & E్ & aspecto & vacuolado & & & & & & & & & & & & & & \\
\hline & & 皇 & $\frac{\pi}{2}$ & & com partículas & $\mathrm{X}$ & $\mathrm{X}$ & $\mathrm{X}$ & & $\mathrm{X}$ & $\mathrm{X}$ & $\mathrm{X}$ & $\mathrm{X}$ & & $\mathrm{X}$ & $\mathrm{X}$ & $\mathrm{X}$ & 10 & \\
\hline & & $\Xi$ & & & regular & & & & & & & & & & & & & & \\
\hline & & $\stackrel{\varrho}{=}$ & & contorno & irregular & $\mathrm{X}$ & $\mathrm{X}$ & $\mathrm{X}$ & & $\mathrm{X}$ & $\mathrm{X}$ & $\mathrm{X}$ & $\mathrm{X}$ & & $\mathrm{X}$ & $\mathrm{X}$ & $\mathrm{X}$ & 10 & \\
\hline & & డ్ & & & & 8 & 8 & 8 & & 5 & 5 & 5 & 3 & & 5 & 15 & 12 & & 7,4 \\
\hline & & $\frac{.00}{200}$ & & distribuicão & ao acaso & $\mathrm{X}$ & $\mathrm{X}$ & $\mathrm{X}$ & & $\mathrm{X}$ & $\mathrm{X}$ & $\mathrm{X}$ & $\mathrm{X}$ & & $\mathrm{X}$ & $\mathrm{X}$ & $\mathrm{X}$ & 10 & \\
\hline & & $\stackrel{0}{=}$ & $\stackrel{8}{\pi}$ & 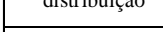 & periféricos & & & & & & & & & & & & & & \\
\hline & & $\frac{5}{9}$ & 芑 & & langhans & & & & & & & & & & & & & & \\
\hline & & & & tipo & $\begin{array}{c}\text { corpo } \\
\text { estranho }\end{array}$ & $\mathrm{X}$ & $\mathrm{X}$ & $\mathrm{X}$ & & $\mathrm{X}$ & $\mathrm{X}$ & $\mathrm{X}$ & $\mathrm{X}$ & & $\mathrm{X}$ & $\mathrm{X}$ & $\mathrm{X}$ & 10 & \\
\hline & & & áreas de & bscedacão & microabcessos & & & & & & & & & & & & & & \\
\hline & Do exsudato & & areas de & Dscedaçao & abcessos & & & & & & & & & & & & & & \\
\hline & & & & fibrina & & & & & & & & & & & & & & & \\
\hline & & ores d & ntensida & e inflamatória & & 2 & 2 & 2 & & 2 & 2 & 3 & 2 & & 2 & 2 & 3 & & 2,20 \\
\hline & & & & edema & & & & & & & & & & & & & & & \\
\hline & Eenômenos & & & hiperemia & & $\mathrm{X}$ & $\mathrm{X}$ & & & & & & & & $\mathrm{X}$ & $\mathrm{X}$ & & 4 & \\
\hline & vasculares & & & hemorragia & & $\mathrm{X}$ & $\mathrm{X}$ & & & & & $\mathrm{X}$ & & & & $\mathrm{X}$ & & 4 & \\
\hline & & & & trombose & & & & & & & & & & & & & & & \\
\hline & & & & iferação fibroblás & & 2 & 1 & 2 & & 2 & 2 & 2 & 2 & & 1 & 2 & 1 & & 1,70 \\
\hline & & & & feração angioblás & & 2 & 3 & 1 & & 2 & 1 & 3 & 3 & & 1 & 2 & 2 & & 2,00 \\
\hline & 焉 & & & den & ade & 2 & 3 & 2 & & 2 & 2 & 2 & 2 & & 2 & 2 & 1 & & 2,00 \\
\hline & 苨 & fibrc & mento & orøanizacã & ao acaso & & & & & & & & & & & & & & \\
\hline & 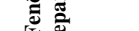 & & & 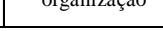 & capsular & $\mathrm{X}$ & $\mathrm{X}$ & $\mathrm{X}$ & & $\mathrm{X}$ & $\mathrm{X}$ & $\mathrm{X}$ & $\mathrm{X}$ & & $\mathrm{X}$ & $\mathrm{X}$ & $\mathrm{X}$ & 10 & \\
\hline & & & tecido $\mathrm{n}$ & neralizado & periférico & & & & & & & & & & & & & & \\
\hline & & & . tectuo in & 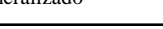 & à distância & & & & & & & & & & & & & & \\
\hline & & & & homogêneo & & & & & & & & & & & & & & & \\
\hline & & & & & granular & $\mathrm{X}$ & $\mathrm{X}$ & $\mathrm{X}$ & & $\mathrm{X}$ & $\mathrm{X}$ & $\mathrm{X}$ & $\mathrm{X}$ & & $\mathrm{X}$ & $\mathrm{X}$ & $\mathrm{X}$ & 10 & \\
\hline & D_ & & não hc & logêneo & com cristais & & & & & & & & & & & & & & \\
\hline &. $\bar{n}$ & & & & fibroso & & & & & & & & & & & & & & \\
\hline & 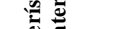 & & & & aquém & & & & & & & & & & & & & & \\
\hline & 气̆ & 10cant & , tho ent I & Yçao d doerturd uo & no nível & $\mathrm{X}$ & $\mathrm{X}$ & $\mathrm{X}$ & & $\mathrm{X}$ & $\mathrm{X}$ & $\mathrm{X}$ & $\mathrm{X}$ & & $\mathrm{X}$ & $\mathrm{X}$ & $\mathrm{X}$ & 10 & \\
\hline & (ृ) & & & & além & & & & & & & & & & & & & & \\
\hline & & & fagc & tável & $\operatorname{sim}$ & $\mathrm{X}$ & $\mathrm{X}$ & $\mathrm{X}$ & & $\mathrm{X}$ & $\mathrm{X}$ & $\mathrm{X}$ & $\mathrm{X}$ & & $\mathrm{X}$ & $\mathrm{X}$ & $\mathrm{X}$ & 10 & \\
\hline & & & & taver & não & & & & & & & & & & & & & & \\
\hline & & & & & & & & & & & & & & & & & & & \\
\hline & 垔 & & & & & & & & & & & & & & & & & & \\
\hline & & & & & & & & & & & & & & & & & & & \\
\hline
\end{tabular}

${ }^{*}$ ) os espécimes correspondentes não propiciaram condições para análise. 


\section{ANEXO 4}

Quadro 3 - Ficha utilizada para registro das análises microscópicas das reações provocadas pelo cimento ProRoot MTA no período de 60 dias.

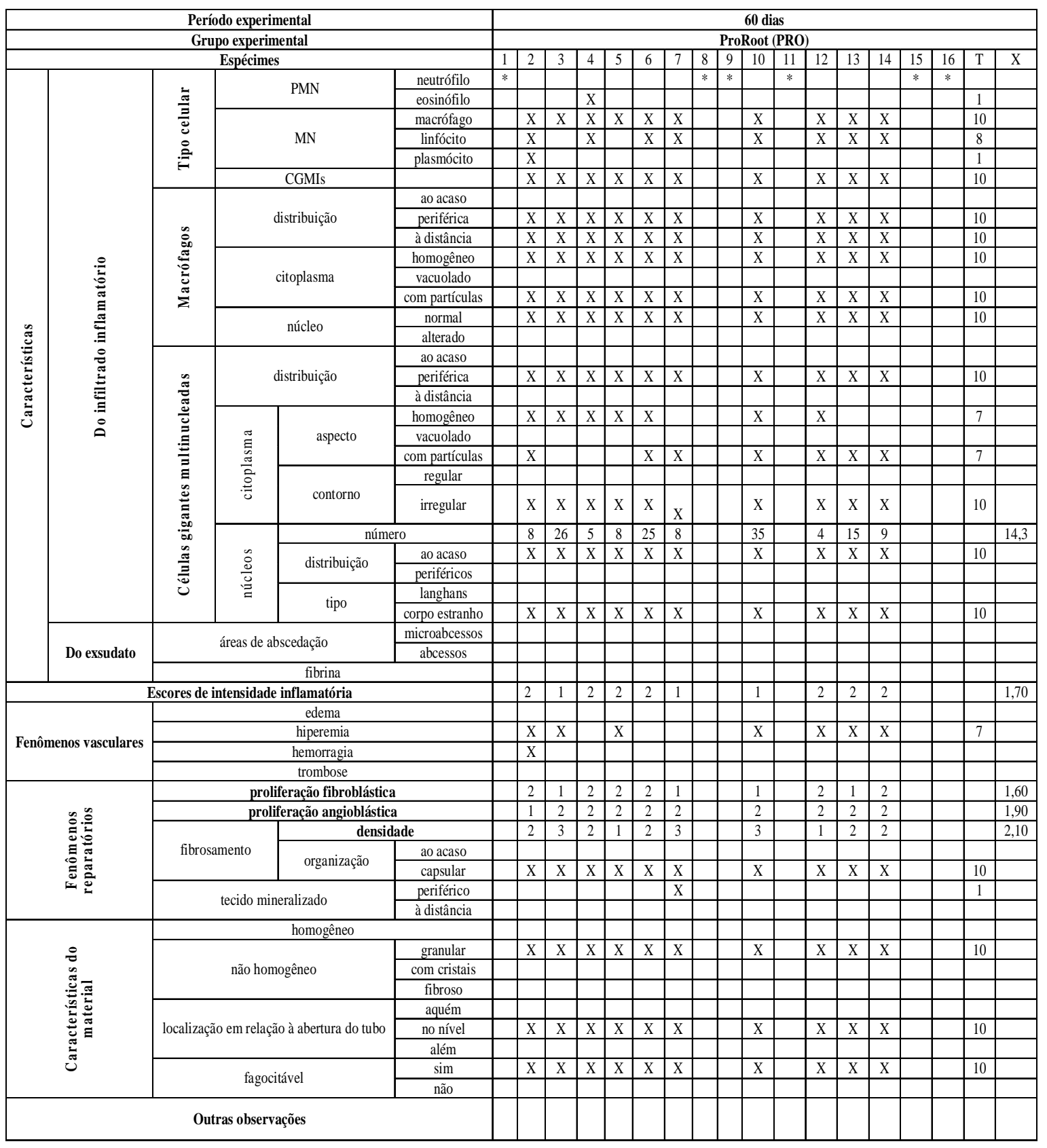

(*) os espécimes correspondentes não propiciaram condições para análise. 


\section{ANEXO 5}

Quadro 4 - Ficha utilizada para registro das análises microscópicas das reações provocadas pelo cimento MTA Branco com sulfato de bário no período de 15 dias.

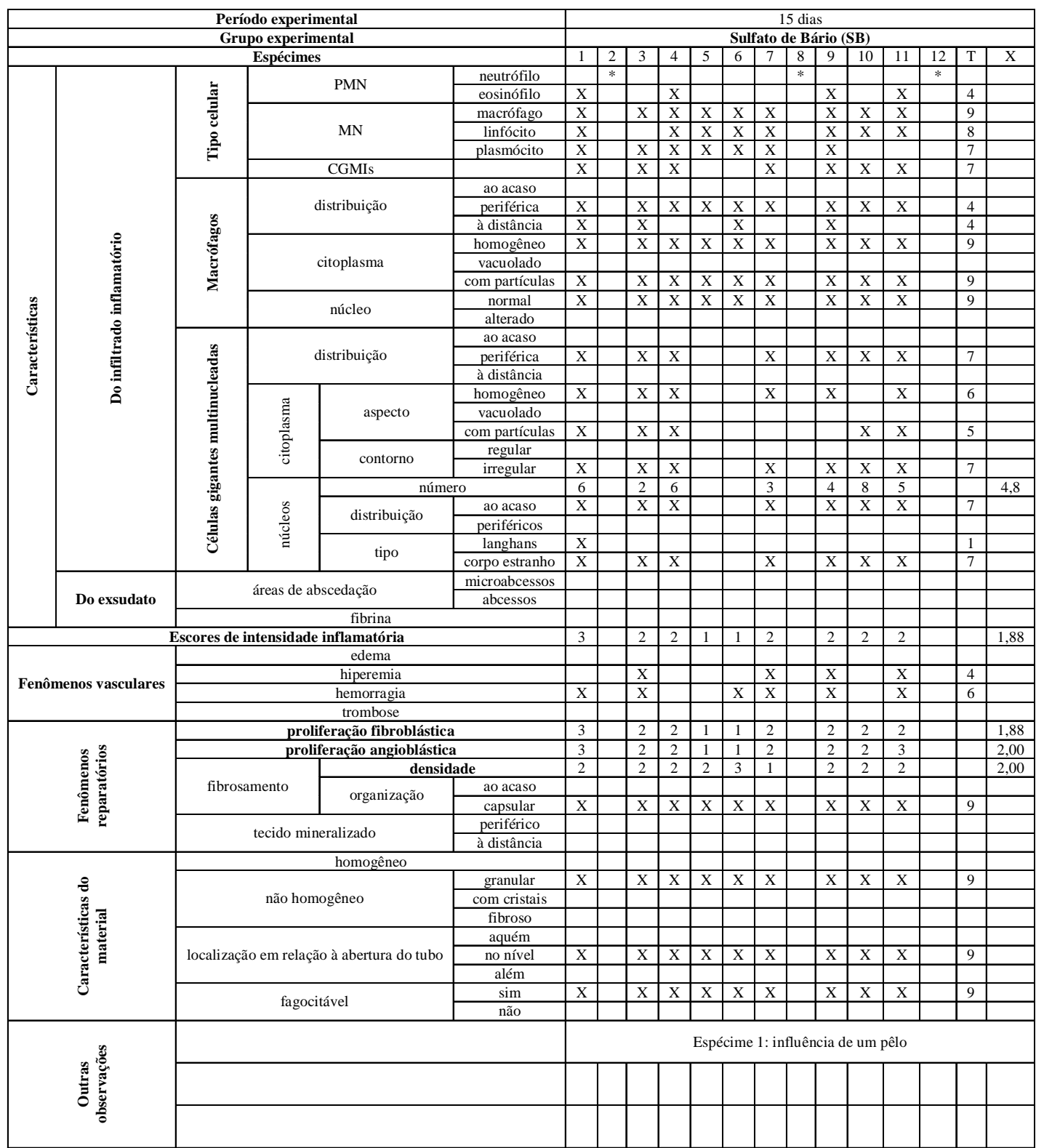

${ }^{*}{ }^{\star}$ os espécimes correspondentes não propiciaram condições para análise. 


\section{ANEXO 6}

Quadro 5 - Ficha utilizada para registro das análises microscópicas das reações provocadas pelo cimento MTA Branco com sulfato de bário no período de 30 dias.

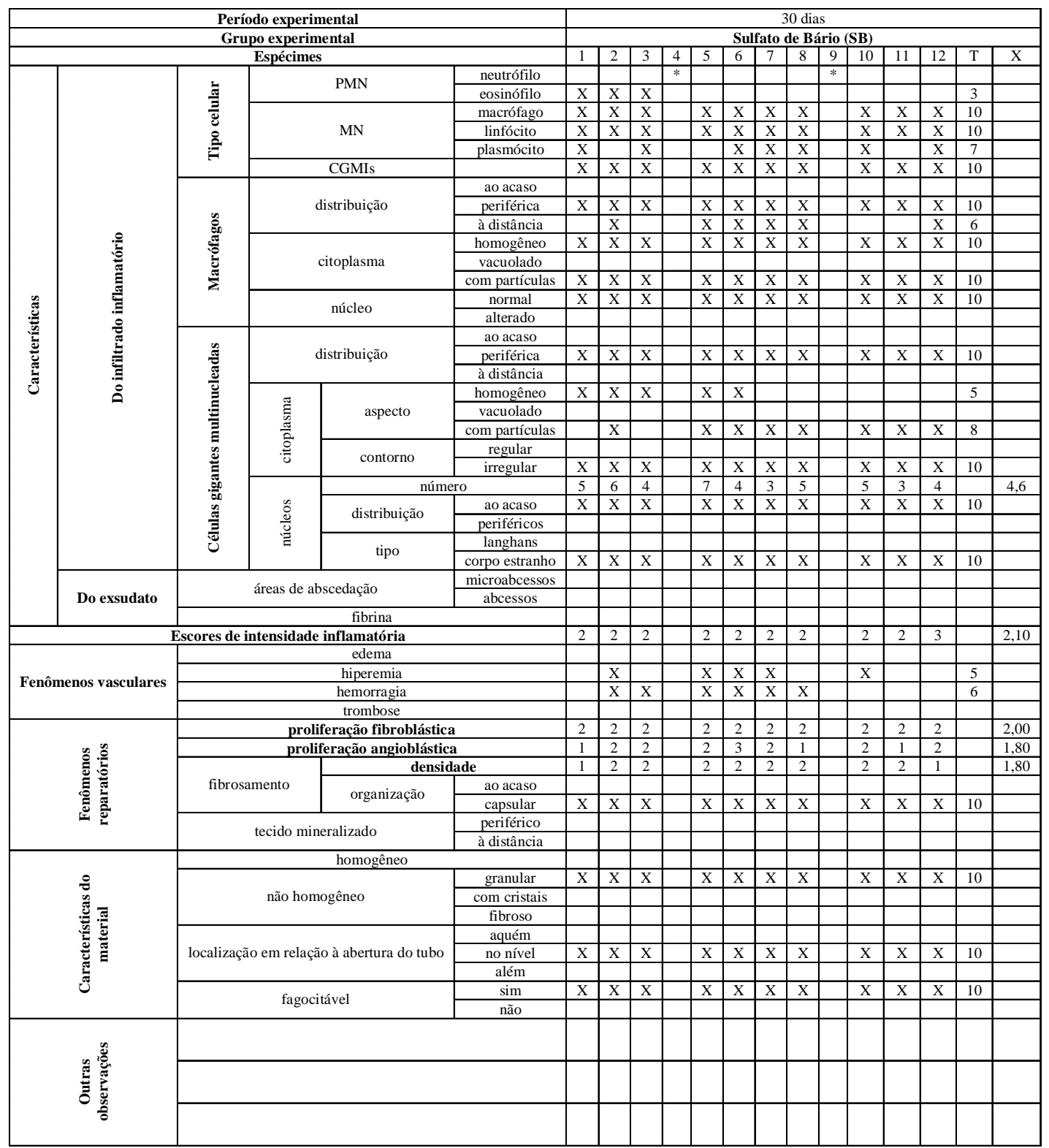

$\left.{ }^{(}\right)$os espécimes correspondentes não propiciaram condições para análise. 


\section{ANEXO 7}

Quadro 6 - Ficha utilizada para registro das análises microscópicas das reações provocadas pelo cimento MTA Branco com sulfato de bário no período de 60 dias.

\begin{tabular}{|c|c|c|c|c|c|c|c|c|c|c|c|c|c|c|c|c|c|c|c|c|c|c|c|}
\hline & & & do expe & nental & & & & & & & & & & & $60 \mathrm{di}$ & & & & & & & & \\
\hline & & & po expe & ental & & & & & & & & & & fato & de B & ário ( & & & & & & & \\
\hline & & & Espécir & & & 1 & 2 & 3 & 4 & 5 & 6 & 7 & 8 & 9 & 10 & 11 & 12 & 13 & 14 & 15 & 16 & $\mathrm{~T}$ & $\mathrm{X}$ \\
\hline & & & & PMN & neutrófilo & $*$ & & & & & & & $*$ & $*$ & & & & & & * & $*$ & & \\
\hline & & $\stackrel{\check{z}}{=}$ & & PMN & eosinófilo & & & & & & & & & & & & & & & & & & \\
\hline & & $\underline{\underline{z}}$ & & & macrófago & & $\mathrm{X}$ & $X$ & $\mathrm{X}$ & $X$ & $\mathrm{X}$ & $X$ & & & $\mathrm{X}$ & & $X$ & $X$ & $X$ & & & 10 & \\
\hline & & $\tilde{u}$ & & MN & linfócito & & $\mathrm{X}$ & & & & & $\mathrm{X}$ & & & $\mathrm{X}$ & & & $\mathrm{X}$ & $X$ & & & 5 & \\
\hline & & & & & plasmócito & & & & & & & & & & & & & & & & & & \\
\hline & & & & CGMIs & & & $X$ & $X$ & $\mathrm{X}$ & $\mathrm{X}$ & $\mathrm{X}$ & $\mathrm{X}$ & & & $\mathrm{X}$ & & $X$ & $\mathrm{X}$ & $X$ & & & 10 & \\
\hline & & & & & ao acaso & & & & & & & & & & & & & & & & & & \\
\hline & & & & distribuição & periférica & & $X$ & $X$ & $\mathrm{X}$ & $X$ & $\mathrm{X}$ & $\mathrm{X}$ & & & $X$ & & $X$ & $\mathrm{X}$ & $X$ & & & 10 & \\
\hline & & Do & & & à distância & & $X$ & $X$ & $X$ & & $X$ & $X$ & & & $\mathrm{X}$ & & $X$ & & $X$ & & & 8 & \\
\hline & & $\overbrace{=0}^{\infty}$ & & & homogêneo & & $X$ & $X$ & $X$ & $\mathrm{X}$ & $X$ & $X$ & & & $\mathrm{X}$ & & $X$ & $\mathrm{X}$ & $X$ & & & 10 & \\
\hline & $\stackrel{\overrightarrow{0}}{\sigma}$ & '0 & & citoplasma & vacuolado & & & & & & & & & & & & & & & & & & \\
\hline & 元 & $\sum^{\pi}$ & & & com partículas & & $X$ & $X$ & $X$ & $X$ & $X$ & $\mathrm{X}$ & & & $X$ & & $X$ & $X$ & $X$ & & & 10 & \\
\hline & $\stackrel{\pi}{=}$ & & & & normal & & $X$ & $X$ & $X$ & $X$ & $X$ & $X$ & & & $X$ & & $X$ & $X$ & $X$ & & & 10 & \\
\hline.$\stackrel{\widetilde{\Xi}}{=}$ & $\underset{0}{. \Xi}$ & & & núcleo & alterado & & & & & & & & & & & & & & & & & & \\
\hline$\frac{2}{2}$ & ت & & & & ao acaso & & & & & & & & & & & & & & & & & & \\
\hline 巳્ & $\Xi$ & $\stackrel{\infty}{\pi}$ & & listribuição & periférica & & $X$ & $X$ & $X$ & $X$ & $X$ & $X$ & & & $X$ & & $X$ & $X$ & $X$ & & & 10 & \\
\hline$\underset{\pi}{\pi}$ &.$\Xi$ & $\Xi$ & & & à distância & & & & $\mathrm{X}$ & & & & & & & & & & & & & 1 & \\
\hline U & 0 & 皇 & & & homogêneo & & $X$ & $X$ & $X$ & $X$ & $\mathrm{X}$ & $\mathrm{X}$ & & & $\mathrm{X}$ & & $\mathrm{X}$ & $\mathrm{X}$ & $X$ & & & 10 & \\
\hline & & E & E్ & aspecto & vacuolado & & & & & & & & & & & & & & & & & & \\
\hline & & $\Xi$ & $\stackrel{\pi}{a}$ & & com partículas & & $X$ & $X$ & $\mathrm{X}$ & $X$ & & & & & $X$ & & $\mathrm{X}$ & $X$ & $X$ & & & 8 & \\
\hline & & $\begin{array}{l}E \\
0 \\
0\end{array}$ & : & & regular & & & & & & & & & & & & & & & & & & \\
\hline & & 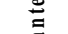 & & contorno & irregular & & $X$ & $X$ & $\mathrm{X}$ & $\mathrm{X}$ & $\mathrm{X}$ & $X$ & & & $\mathrm{X}$ & & $X$ & $\mathrm{X}$ & $X$ & & & 10 & \\
\hline & & $\stackrel{\pi}{\infty}$ & & núm & & & 7 & 5 & 20 & 10 & 15 & 8 & & & 8 & & 12 & 5 & 12 & & & & 10,2 \\
\hline & & bo & $\approx$ & distrihuicãn & a0 acaso & & $\mathrm{X}$ & $X$ & $X$ & $X$ & $\mathrm{X}$ & $\mathrm{X}$ & & & $\mathrm{X}$ & & $X$ & $\mathrm{X}$ & $X$ & & & 10 & \\
\hline & & $\stackrel{\widetilde{\Xi}}{\Xi}$ & $\frac{\tilde{\sigma}}{\breve{U}}$ & & periféricos & & & & & & & & & & & & & & & & & & \\
\hline & & ت্ & & & langhans & & & & & & & & & & & & & & & & & & \\
\hline & & & & tipo & corpo estranho & & $X$ & $\mathrm{X}$ & $\mathrm{X}$ & $\mathrm{X}$ & $\mathrm{X}$ & $\mathrm{X}$ & & & $\mathrm{X}$ & & $\mathrm{X}$ & $\mathrm{X}$ & $\mathrm{X}$ & & & 10 & \\
\hline & & & áreas df & sccedacão & microabcessos & & & & & & & & & & & & & & & & & & \\
\hline & Do exsudato & & areas de & jscedaçao & abcessos & & & & & & & & & & & & & & & & & & \\
\hline & & & & fibrina & & & & & & & & & & & & & & & & & & & \\
\hline & & scores de & ntensida & inflamatória & & & 2 & 1 & 2 & 2 & 2 & 2 & & & 2 & & 2 & 2 & 1 & & & & 1,80 \\
\hline & & & & edema & & & & & & & & & & & & & & & & & & & \\
\hline Fon & & & & hiperemia & & & $\mathrm{X}$ & & $X$ & & & & & & & & $X$ & $X$ & & & & 4 & \\
\hline Fent & enos vasculares & & & hemorragia & & & $X$ & & & $\mathrm{X}$ & $\mathrm{X}$ & & & & & & $X$ & $\mathrm{X}$ & & & & 5 & \\
\hline & & & & trombose & & & & & & & & & & & & & & & & & & & \\
\hline & & & & feração fibroblástic & & & 2 & 1 & 2 & 2 & 2 & 2 & & & 2 & & 2 & 2 & 1 & & & & 1,80 \\
\hline & & & & feração angioblástic & & & 2 & 1 & 2 & 1 & 2 & 2 & & & 2 & & 3 & 2 & 2 & & & & 1,90 \\
\hline & 产: & & & \begin{tabular}{|r} 
densic \\
\end{tabular} & & & 2 & 3 & 2 & 1 & 1 & 3 & & & 2 & & 2 & 2 & 3 & & & & 2,10 \\
\hline & 西 & fibro & mento & оrøanizaว̃̃ & a0 acaso & & & & & & & & & & & & & & & & & & \\
\hline & 谒 & & & organızaçao & capsular & & $X$ & $\mathrm{X}$ & $\mathrm{X}$ & $\mathrm{X}$ & $\mathrm{X}$ & $\mathrm{X}$ & & & $\mathrm{X}$ & & $\mathrm{X}$ & $\mathrm{X}$ & $X$ & & & 10 & \\
\hline & & & tecidor & aralizadn & periférico & & & & & & & & & & & & & & & & & & \\
\hline & & & tecido I & leralızado & à distância & & & & & & & & & & & & & & & & & & \\
\hline & & & & homogêneo & & & & & & & & & & & & & & & & & & & \\
\hline & & & & & granular & & $\mathrm{X}$ & $X$ & $\mathrm{X}$ & $X$ & $X$ & $X$ & & & $X$ & & $\mathrm{X}$ & $X$ & $\mathrm{X}$ & & & 10 & \\
\hline & $=$ & & não h & ogêneo & com cristais & & & & & & & & & & & & & & & & & & \\
\hline & 馬. & & & & fibroso & & & & & & & & & & & & & & & & & & \\
\hline & 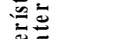 & & & & aquém & & & & & & & & & & & & & & & & & & \\
\hline & $\stackrel{\Xi}{\Xi}$ & localiza & 0 em rel & io à abertura do tubo & no nível & & $\mathrm{X}$ & $\mathrm{X}$ & $\mathrm{X}$ & $\mathrm{X}$ & $\mathrm{X}$ & $\mathrm{X}$ & & & $\mathrm{X}$ & & $\mathrm{X}$ & $\mathrm{X}$ & $X$ & & & 10 & \\
\hline & $\pi$ & & & & além & & & & & & & & & & & & & & & & & & \\
\hline & & & & tável & sim & & $X$ & $X$ & $\mathrm{X}$ & $\mathrm{X}$ & $\mathrm{X}$ & $\mathrm{X}$ & & & $\mathrm{X}$ & & $X$ & $\mathrm{X}$ & $X$ & & & 10 & \\
\hline & & & & tavel & não & & & & & & & & & & & & & & & & & & \\
\hline & & & ras obse & ações & & & & & & & & & & & & & & & & & & & \\
\hline
\end{tabular}

(*) os espécimes correspondentes não propiciaram condições para análise. 


\section{ANEXO 8}

Quadro 7 - Ficha utilizada para registro das análises microscópicas das reações provocadas pelo cimento MTA Branco com óxido de bismuto no período de 15 dias.

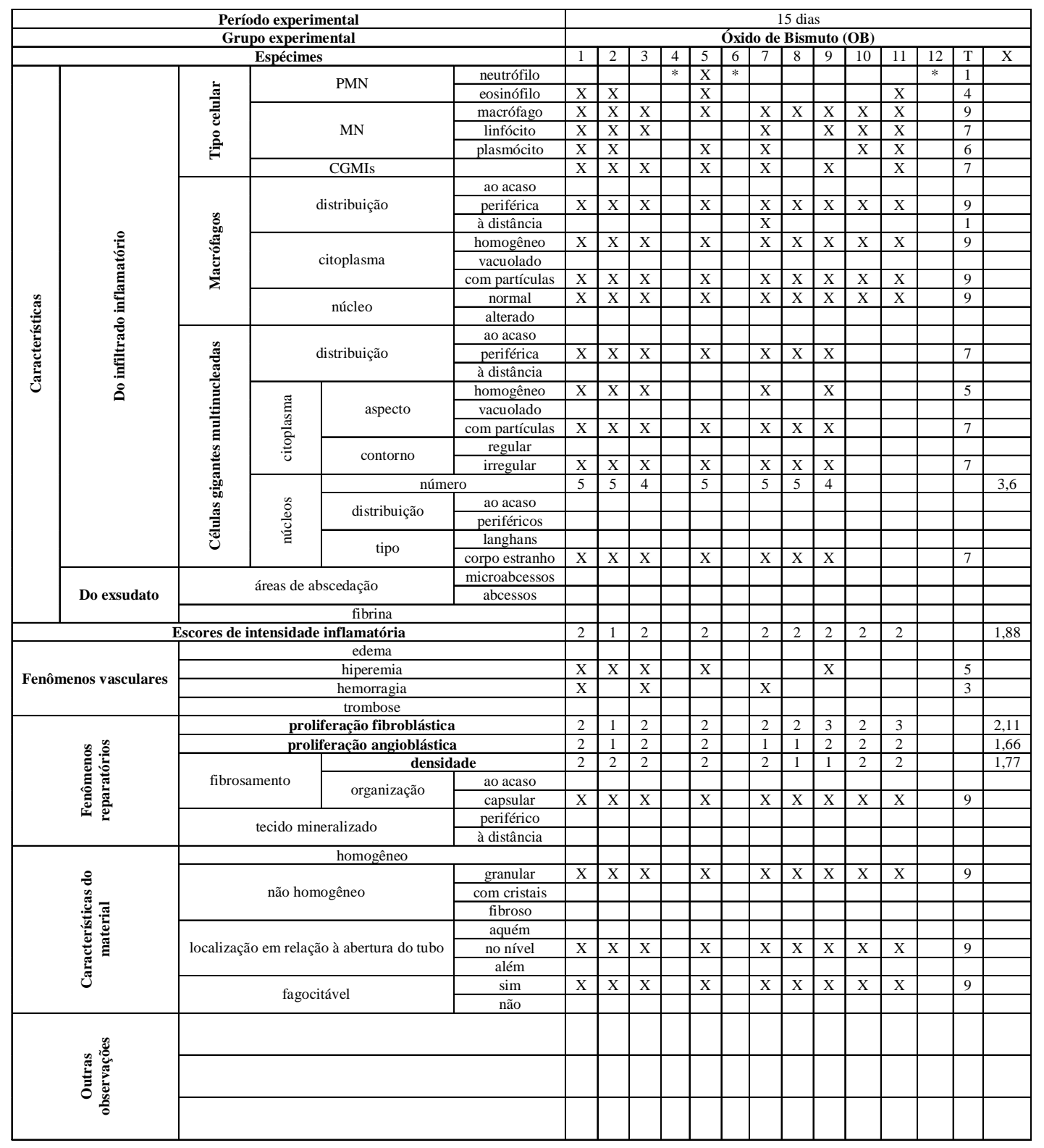

${ }^{*}$ ) os espécimes correspondentes não propiciaram condições para análise. 


\section{ANEXO 9}

Quadro 8 - Ficha utilizada para registro das análises microscópicas das reações provocadas pelo cimento MTA Branco com óxido de bismuto no período de 30 dias.

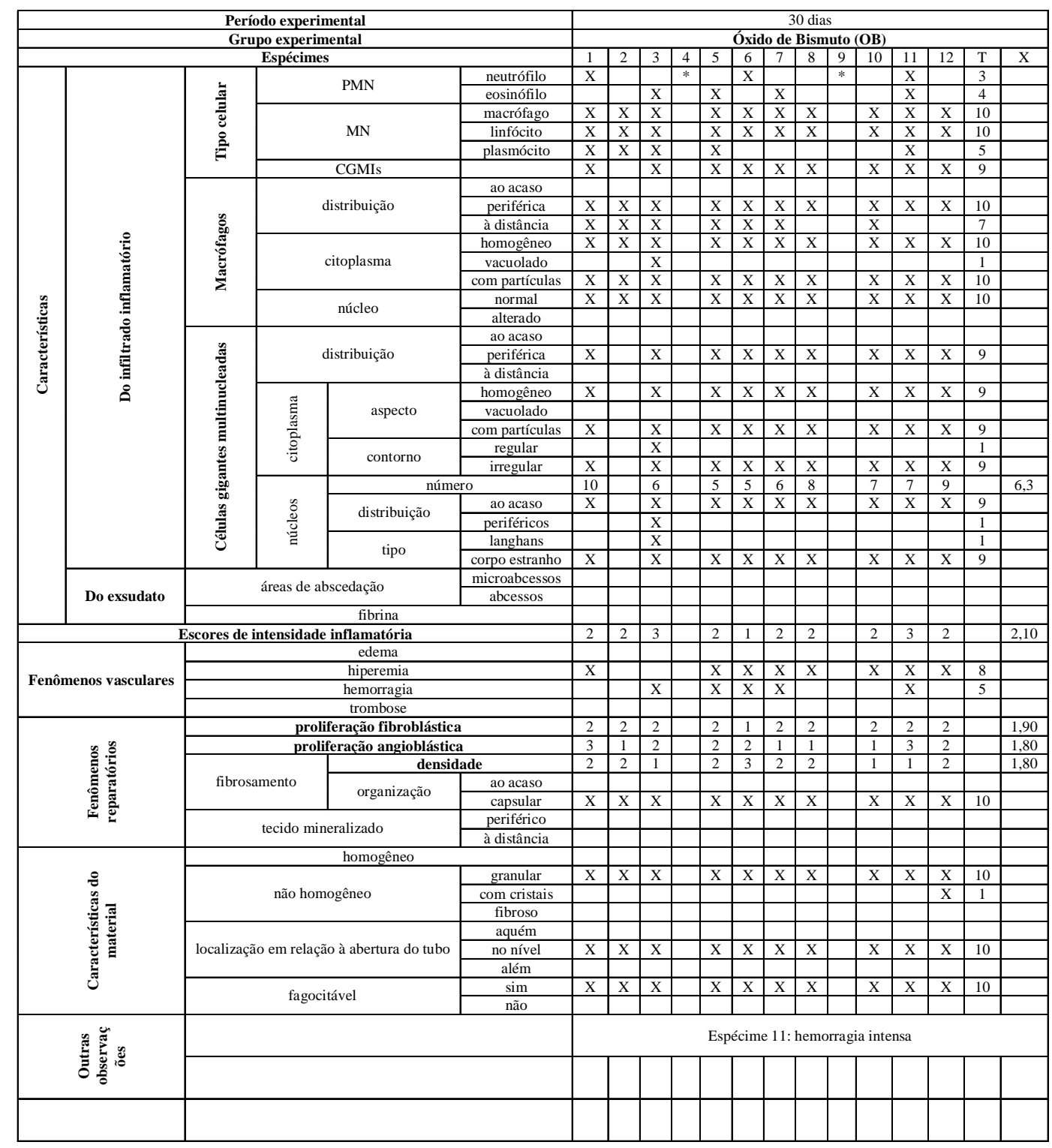

(*) os espécimes correspondentes não propiciaram condições para análise. 


\section{ANEXO 10}

Quadro 9 - Ficha utilizada para registro das análises microscópicas das reações provocadas pelo cimento MTA Branco com óxido de bismuto no período de 60 dias.

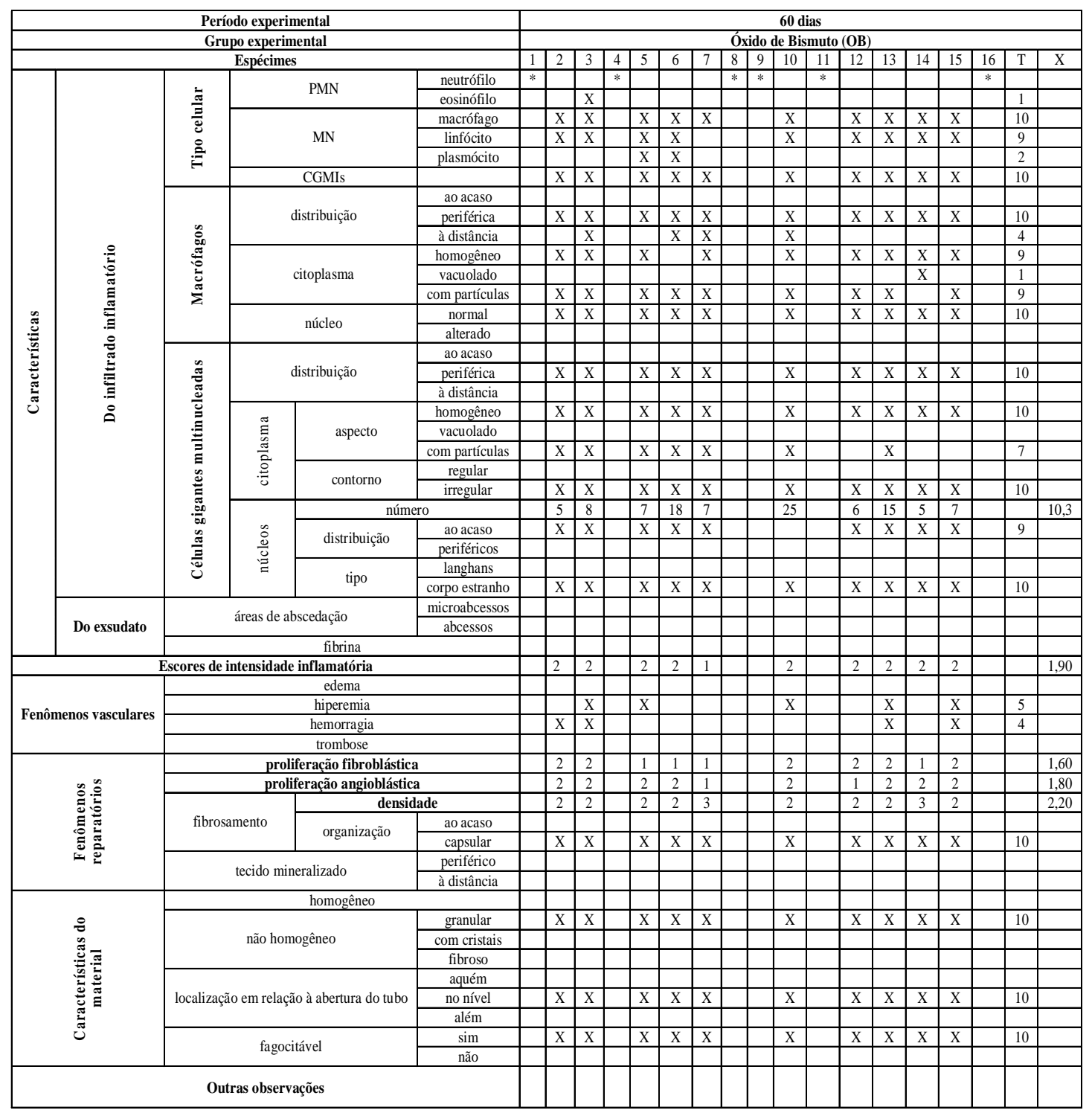

(*) os espécimes correspondentes não propiciaram condições para análise. 


\section{ANEXO 11}

Quadro 10 - Ficha utilizada para registro das análises microscópicas das reações provocadas pelo cimento Portland com óxido bismuto no período de 15 dias.

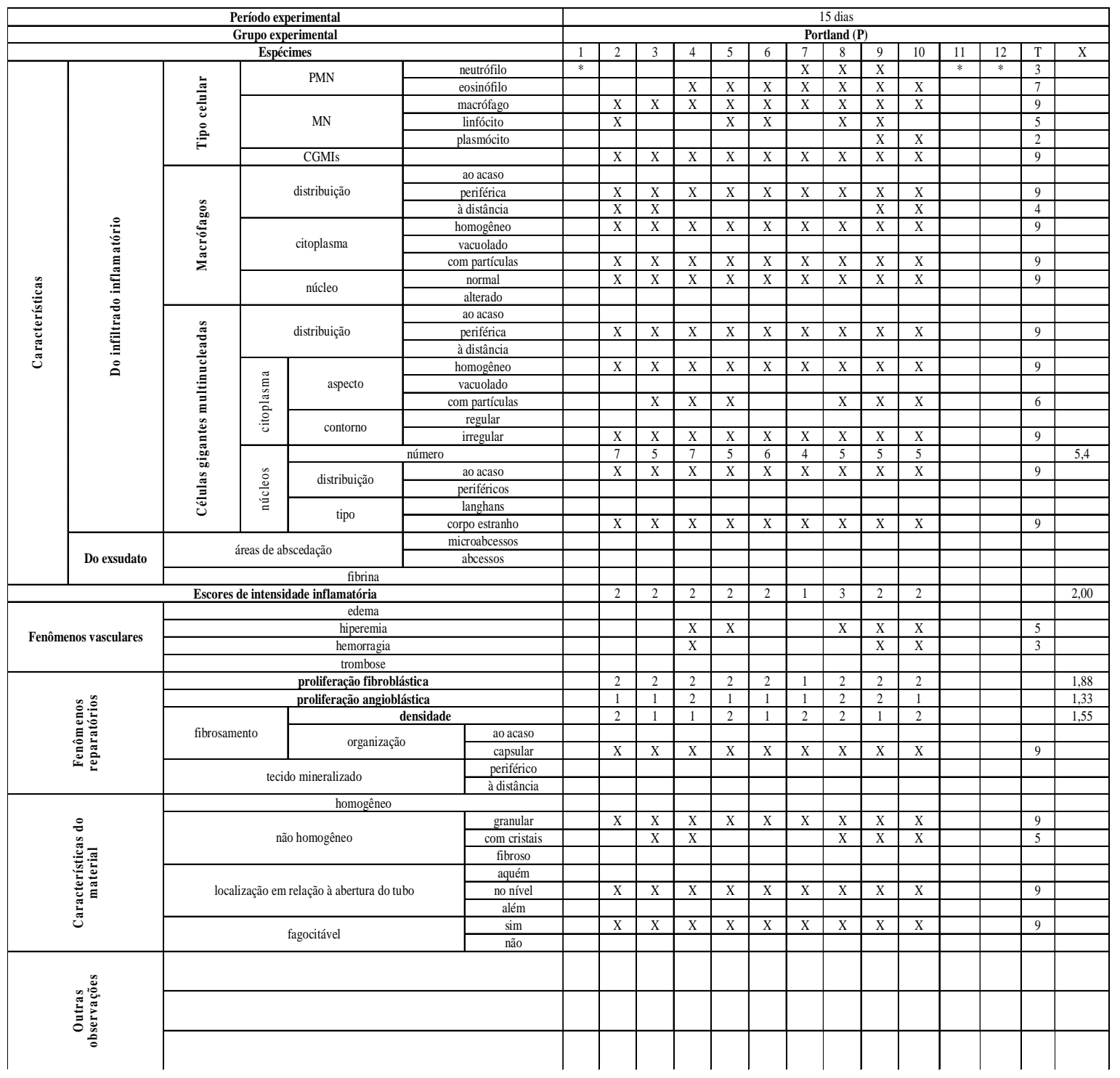

$\left.{ }^{(}\right)$os espécimes correspondentes não propiciaram condições para análise. 


\section{ANEXO 12}

Quadro 11 - Ficha utilizada para registro das análises microscópicas das reações provocadas pelo cimento Portland com óxido bismuto no período de 30 dias.

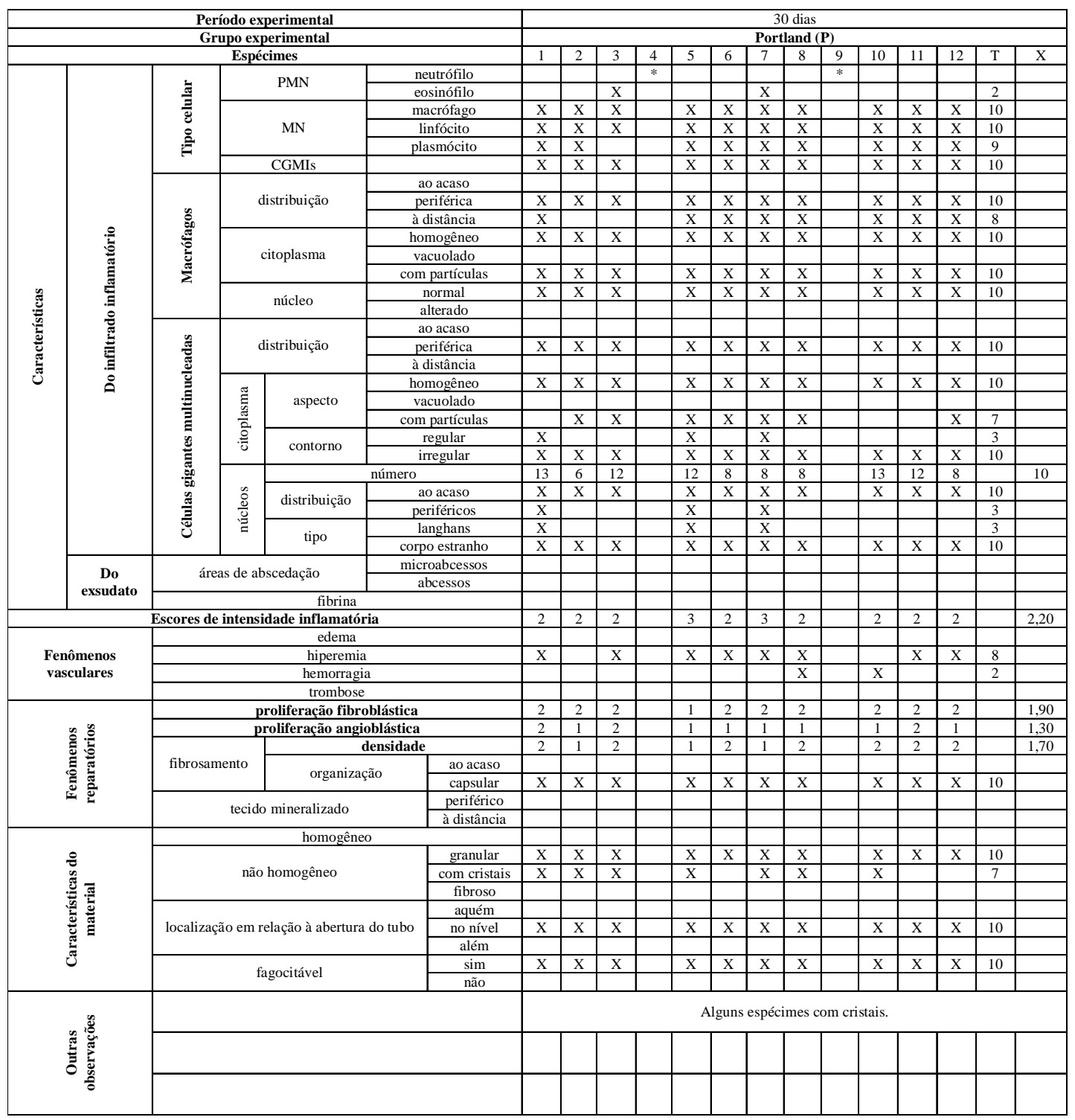

(*) os espécimes correspondentes não propiciaram condições para análise. 


\section{ANEXO 13}

Quadro 12 - Ficha utilizada para registro das análises microscópicas das reações provocadas pelo cimento Portland com óxido bismuto no período de 60 dias.

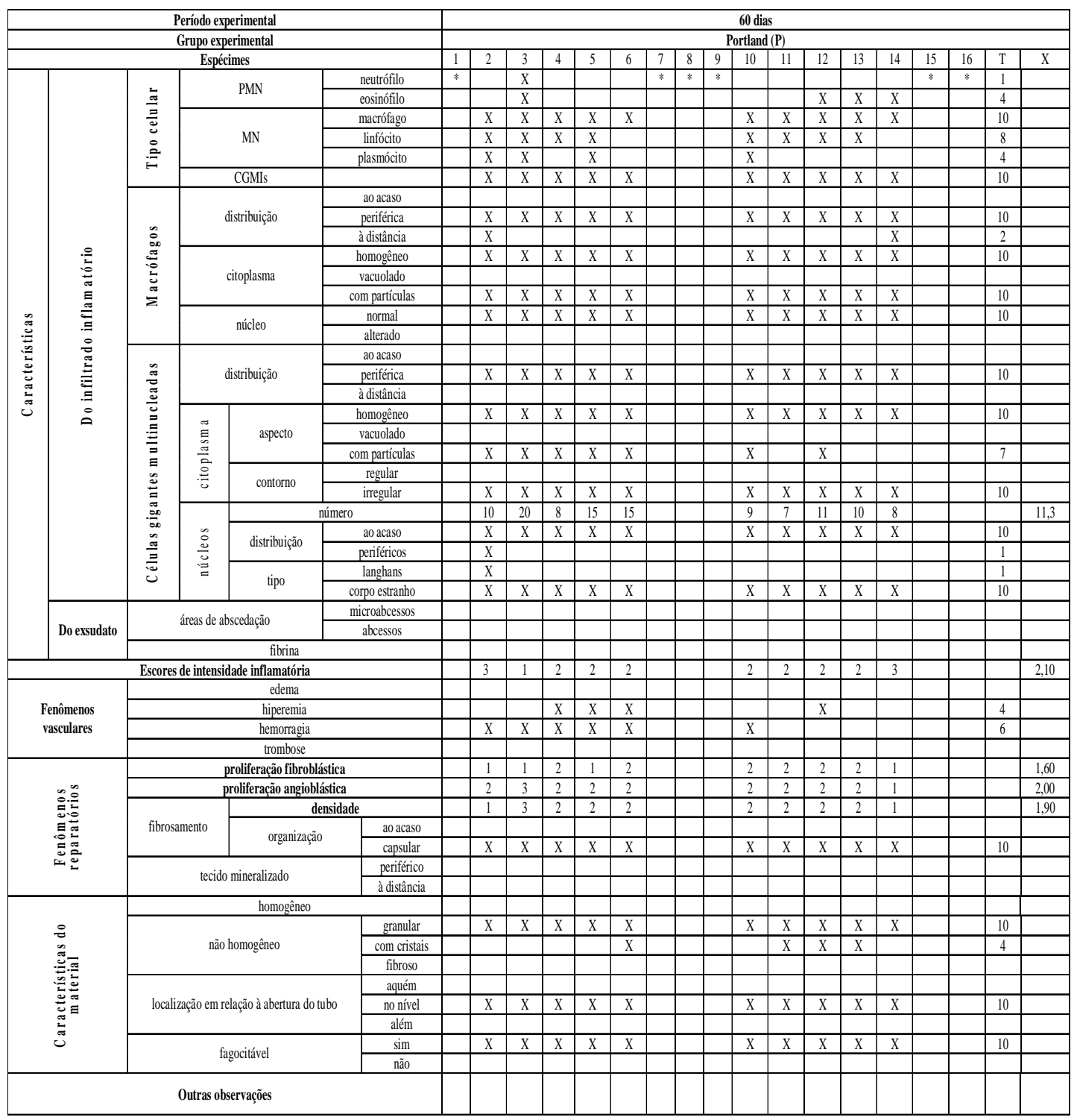

(*) os espécimes correspondentes não propiciaram condições para análise. 


\section{ANEXO 14}

Quadro 13 - Ficha utilizada para registro das análises microscópicas das reações provocadas pela guta-percha nos períodos de 15,30 e 60 dias.

\begin{tabular}{|c|c|c|c|c|c|c|c|c|c|c|c|c|c|c|c|c|c|}
\hline \multirow{2}{*}{\multicolumn{6}{|c|}{$\begin{array}{l}\text { Grupo experimental } \\
\text { Período experimental }\end{array}$}} & \multicolumn{12}{|c|}{ Guta-percha (controle) } \\
\hline & & & & & & \multicolumn{4}{|c|}{15 dias } & \multicolumn{4}{|c|}{30 dias } & \multicolumn{4}{|c|}{60 dias } \\
\hline \multicolumn{6}{|c|}{ Espécimes } & 1 & 2 & 3 & 4 & 5 & 6 & 7 & 8 & 9 & 10 & 11 & 12 \\
\hline \multirow{30}{*}{ 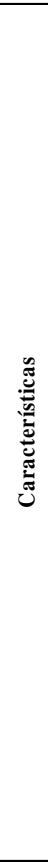 } & \multirow{27}{*}{ 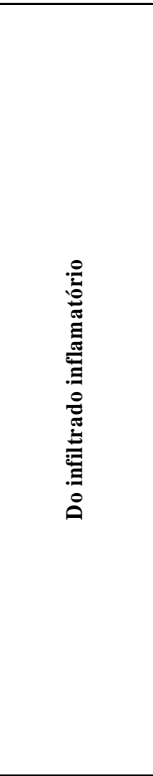 } & \multirow{6}{*}{ 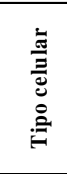 } & \multirow{2}{*}{\multicolumn{2}{|c|}{ PMN }} & neutrófilo & $\mathrm{X}$ & $\mathrm{X}$ & & $\mathrm{X}$ & & $\mathrm{X}$ & $\mathrm{X}$ & & & & & \\
\hline & & & & & eosinófilo & $\mathrm{X}$ & $\mathrm{X}$ & $\mathrm{X}$ & $\mathrm{X}$ & & $\mathrm{X}$ & $\mathrm{X}$ & & & & & \\
\hline & & & \multirow{4}{*}{\multicolumn{2}{|c|}{ MN }} & macrófago & $\mathrm{X}$ & $\mathrm{X}$ & $\mathrm{X}$ & $\mathrm{X}$ & $\mathrm{X}$ & $\mathrm{X}$ & $\mathrm{X}$ & $\mathrm{X}$ & $\mathrm{X}$ & $\mathrm{X}$ & $\mathrm{X}$ & $\mathrm{X}$ \\
\hline & & & & & linfócito & $\mathrm{X}$ & $\mathrm{X}$ & $\mathrm{X}$ & $\mathrm{X}$ & $\mathrm{X}$ & $\mathrm{X}$ & $\mathrm{X}$ & $\mathrm{X}$ & & $\mathrm{X}$ & & $\mathrm{X}$ \\
\hline & & & & & plasmócito & & & & & & & & & & & & \\
\hline & & & & & & & $\mathrm{X}$ & $\mathrm{X}$ & & $\mathrm{X}$ & & $\mathrm{X}$ & & $\mathrm{X}$ & & & \\
\hline & & \multirow{8}{*}{ 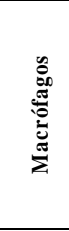 } & \multirow{3}{*}{\multicolumn{2}{|c|}{ distribuição }} & ao acaso & & & & & & & & & & & & \\
\hline & & & & & periférica & $\mathrm{X}$ & $\mathrm{X}$ & $\mathrm{X}$ & $\mathrm{X}$ & $\mathrm{X}$ & $\mathrm{X}$ & $\mathrm{X}$ & $\mathrm{X}$ & $\mathrm{X}$ & $\mathrm{X}$ & $\mathrm{X}$ & $\mathrm{X}$ \\
\hline & & & & & à distância & & & & & & & & & & & & $\mathrm{X}$ \\
\hline & & & & & homogêneo & $\mathrm{X}$ & $\mathrm{X}$ & $\mathrm{X}$ & $\mathrm{X}$ & $\mathrm{X}$ & $\mathrm{X}$ & $\mathrm{X}$ & $\mathrm{X}$ & $\mathrm{X}$ & $\mathrm{X}$ & $\mathrm{X}$ & $\mathrm{X}$ \\
\hline & & & & itoplasma & vacuolado & & $\mathrm{X}$ & & & & & & & & & & \\
\hline & & & & & com partículas & $\mathrm{X}$ & & $\mathrm{X}$ & & & $\mathrm{X}$ & $\mathrm{X}$ & & & & & \\
\hline & & & & púcleo & normal & $\mathrm{X}$ & $\mathrm{X}$ & $\mathrm{X}$ & $\mathrm{X}$ & $\mathrm{X}$ & $\mathrm{X}$ & $\mathrm{X}$ & $\mathrm{X}$ & $\mathrm{X}$ & $\mathrm{X}$ & $\mathrm{X}$ & $\mathrm{X}$ \\
\hline & & & & nucleo & alterado & & & & & & & & & & & & \\
\hline & & & & & ao acaso & & & & & & & & & & & & \\
\hline & & & & istribuição & periférica & & $\mathrm{X}$ & $\mathrm{X}$ & & $\mathrm{X}$ & & $\mathrm{X}$ & & $\mathrm{X}$ & & & \\
\hline & & ङ & & & à distância & & & & & & & & & & & & \\
\hline & & $\bar{\Xi}$ & & & homogêneo & & $\mathrm{X}$ & & & $\mathrm{X}$ & & $\mathrm{X}$ & & & & & \\
\hline & & 足 & E్ & aspecto & vacuolado & & & & & & & & & & & & \\
\hline & & $\bar{\Xi}$ & $\frac{\pi}{2}$ & & com partículas & & $\mathrm{X}$ & $\mathrm{X}$ & & $\mathrm{X}$ & & $\mathrm{X}$ & & $\mathrm{X}$ & & & \\
\hline & & $\underset{\infty}{E}$ & . & & regular & & & & & & & & & & & & \\
\hline & & $\stackrel{\mathscr{U}}{\Xi}$ & & contorno & irregular & & $\mathrm{X}$ & $\mathrm{X}$ & & $\mathrm{X}$ & & $\mathrm{X}$ & & $\mathrm{X}$ & & & \\
\hline & & 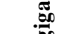 & & núme & & & 5 & 3 & & 25 & & 10 & & 8 & & & \\
\hline & & का & & & ao acaso & & $\mathrm{X}$ & $\mathrm{X}$ & & $\mathrm{X}$ & & $\mathrm{X}$ & & $\mathrm{X}$ & & & \\
\hline & & $\frac{\pi}{3}$ & $\stackrel{\varrho}{U}$ & distribuição & periféricos & & & & & & & & & & & & \\
\hline & & & & & langhans & & & & & & & & & & & & \\
\hline & & & & tipo & corpo estranho & & $\mathrm{X}$ & $\mathrm{X}$ & & $\mathrm{X}$ & & $\mathrm{X}$ & & $\mathrm{X}$ & & & \\
\hline & & & áreasc de & scedacã & microabcessos & & & & & & & & & & & & \\
\hline & Do exsudato & & areas de & scedaçao & abcessos & & & & & & & & & & & & \\
\hline & & & & fibrina & & & & & & & & & & & & & \\
\hline & & cores d & ntensidac & inflamatória & & & & & & & & & & & & & \\
\hline & & & & edema & & & & & & & & & & & & & \\
\hline & & & & hiperemia & & $\mathrm{X}$ & $\mathrm{X}$ & $\mathrm{X}$ & $\mathrm{X}$ & & $\mathrm{X}$ & $\mathrm{X}$ & $\mathrm{X}$ & & & & \\
\hline Fenô & nos vasculares & & & hemorragia & & $\mathrm{X}$ & $\mathrm{X}$ & $\mathrm{X}$ & $\mathrm{X}$ & $\mathrm{X}$ & & $\mathrm{X}$ & & & & & \\
\hline & & & & trombose & & & & & & & & & & & & & \\
\hline & & & & feração fibroblástica & & & & & & & & & & & & & \\
\hline & & & & eração angioblástic & & & & & & & & & & & & & \\
\hline & 吾 & & & densid & & & & & & & & & & & & & \\
\hline & 光 & fibro & mento & & ao acaso & & & & & & & & & & & & \\
\hline & $\stackrel{0}{0}$ & & & organizaçăo & capsular & $\mathrm{X}$ & $\mathrm{X}$ & $\mathrm{X}$ & $\mathrm{X}$ & $\mathrm{X}$ & $\mathrm{X}$ & $\mathrm{X}$ & $\mathrm{X}$ & $\mathrm{X}$ & $\mathrm{X}$ & $\mathrm{X}$ & $\mathrm{X}$ \\
\hline & & & & & periférico & & & & & & & & & & & & \\
\hline & & & tecido $\mathrm{m}$ & eralizado & à distância & & & & & & & & & & & & \\
\hline & & & & homogêneo & & & & & & & & & & & & & \\
\hline & & & & & granular & $\mathrm{X}$ & $X$ & $X$ & $\mathrm{X}$ & $\mathrm{X}$ & $X$ & $X$ & $X$ & $X$ & $X$ & $X$ & $\mathrm{X}$ \\
\hline & s & & não ho & ogêneo & com cristais & & & & & & & & & & & & \\
\hline &. & & & & fibroso & & & & & & & & & & & & \\
\hline & 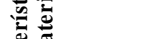 & & & & aquém & & & & & & & & & & & & \\
\hline & 巳ँ & localiza & o em rela & o à abertura do tubo & no nível & $\mathrm{X}$ & $\mathrm{X}$ & $\mathrm{X}$ & $\mathrm{X}$ & $\mathrm{X}$ & $\mathrm{X}$ & $\mathrm{X}$ & $\mathrm{X}$ & $\mathrm{X}$ & $\mathrm{X}$ & $\mathrm{X}$ & $\mathrm{X}$ \\
\hline & స్ & & & & além & & & & & & & & & & & & \\
\hline & & & & & $\operatorname{sim}$ & $\mathrm{X}$ & & $\mathrm{X}$ & & & $\mathrm{X}$ & $\mathrm{X}$ & & & & & \\
\hline & & & fago & tável & não & & $\mathrm{X}$ & & $\mathrm{X}$ & $\mathrm{X}$ & & & $\mathrm{X}$ & $\mathrm{X}$ & $\mathrm{X}$ & $\mathrm{X}$ & $\mathrm{X}$ \\
\hline
\end{tabular}




\section{REFERÊNCIAS BIBLIOGRAFICAS}




\section{REFERÊNCIAS BIBLIOGRÁFICAS*}

1 ABDULLAH, D. An evaluation of accelerated Portland cement as a restorative material. Biomaterials, v.23, n.19, p.4001-10, Oct. 2002.

2 ABEDI, H.R.; INGLE, J.I. Mineral trioxide aggregate: a review of a new cement. J Calif Dent Ass, v.23, n.12, p.36-9, Dec. 1995.

3 ABEDI, H.R. et al. The use mineral tri-oxide aggregate cement (MTA) as a direct pulp capping agent. J Endod, v.22, n.4, p.199, Apr. 1996. /Abstract n. 44/

4 ADAMO, H.L. et al. A comparison of MTA, super EBA, composite and amalgam as root-end filling materials using bacterial microleakage model. Int Endod J, v.32, p.197-203, May 1999.

5 AEINEHCHI, M. et al. Mineral trioxide aggregate (MTA) and calcium hydroxide as pulp-capping agents in human teeth: a preliminary report. Int Endod J, v.36, n.3, p.225-31, Mar. 2003.

6 AMERICAN DENTAL ASSOCIATION - Council on Dental Materials and Devices of the American Dental Association. J Amer Dent Assoc, v.84, p.375-95, Feb. 1972.

AMERICAN NATIONAL STANDARDS / AMERICAN DENTAL ASSOCIATION. Document $\mathbf{n}^{\circ} \mathbf{4 1}$ for recommended standard practices for biological evaluation of dental materials. New York, ANSI/ADA, 1982.

\footnotetext{
*Normas recomendadas para o uso no âmbito da Universidade de São Paulo, com base no documento "Referências Bibliográficas: exemplos", emanados do Conselho Supervisor do Sistema Integrado de Bibliotecas da USP em reunião de 20 de setembro de 1990.
} 
8 ANTUNES, F.P.G.C. et al. Avaliação in vitro da citotoxicidade do MTA e Super EBA em cultura de fibroblastos embrionários. Braz Oral Res, v.16, p.99, 2002. Supplement. /Abstract n. Ic078/

9 AQRABAWI, J. Sealing ability of amalgam, super EBA cement, and MTA when used as retrograde filling materials. Br Dent J, v.188, n.5, p.2668, Mar. 2000.

10 ARENS, D.E.; TORABINEJAD, M. Repair of furcal perforations with mineral trioxide aggregate - two cases reports. Oral Surg Oral Med Oral Pathol, v.82, n.1, p.84-8, July 1996.

11 ASRARI, M; LOBNER, D. Mechanism of in vitro neurotoxicity of root-end filling materials. J Endod, v.29, n.4, p.300, Apr. 2003. IAbstract n. 5/

12 ASRARI, M.; LOBNER, D. Mechanism of in vitro neurotoxicity of root-end filling materials. J Endod, v.29, n.11, p.743-6, Nov. 2003.

13 BATES, C.F.; CARNES, D.L.; DEL RIO, C.E. Longitudinal sealing ability of mineral trioxide aggregate as a root-end filling material. J Endod, v.22, n.11, p.575-8, Nov. 1996.

14 BERÁSTEGUI JIMENO, E.M. Actualización sobre el Proroot-MTA en el año 2002. Endodoncia, v.21, n.1, p.36-49, ene./mar. 2003.

15 BERBERT, C.C.V.; CONSOLARO, A. Influência de cimentos endodônticos na migração neutrofílica pelo teste de skin window. Rev Fac Odontol Bauru, v.21, n.2, p.81-7, abr./maio/jun. 1994. 
16 BERNABÉ, P.F.E.; HOLLAND, R. Cirurgia parendodôntica: quando indicar e como realizá-la. In: GONÇALVES, E.A; FELLER, C. Atualização na clínica odontológica: a prática da clínica geral. São Paulo: Artes Médicas; 1998. p.217-54.

17 BERNABÉ P.F.E.; HOLLAND, R. Cirurgia paraendodôntica: como practicá-la com embasamento científico. In: ESTRELA, C. Ciência endodôntica. São Paulo, Artes médicas, 2004. Cap.16, p.657-797.

18 BORTOLUZZI, E.A.; BROON, N.J.; BRAMANTE, C.M. Avaliação da capacidade seladora do MTA e cimento portland com ou sem cloreto de cálcio em obturações retrógradas. Braz Oral Res, v.18, p.213, Sept. 2004. Supplement. IAbstract n. Pc082/

19 BOULGER, E.P. The foreign body reaction of rat tissue and human tissue to guta-percha. J Amer Dent Ass, v.20, n.80, p.1473-81, Aug. 1993.

20 BRAMANTE, C.M.; BERBERT, A. Cirurgia parendodôntica. São Paulo, Ed. Santos, 2000.

21 BRAMANTE, C.M.; BERBERT, A.; BERNARDINELI, N. Retroinstrumentação e retroobturação. RGO, v.40, n.1, p.38-40, jan./fev. 1992.

22 BRAMANTE, C.M.; BORTOLUZZI, E.A. BROON, N.J. Agregado Trióxido Mineral (MTA) como plug para la obturación de conductos radiculares: descripción de la técnica y caso clínico. Endodoncia, v.22, n.3, p.155-61, jul./set. 2004.

23 BRITTO, L.R. et al. Delay in setting of MTA by blood proteins: a pilot study. J Endod, v.29, n.4, p.309, Apr. 2003. IAbstract n. PR44/ 
24 BROWNE, R.M.; FRIEND, L.A. An investigation into irritant properties of some root filling materials. Archs Oral Biol, v.13, n.2, p.1355-70, July/Dec. 1968.

25 CAICEDO, R.; BECERRA, P.; BONILLA, S.M. Effect of different endodontic materials on cellular fibroblasts. J Endod, v.26, n.9, p.554, Sept. 2000. /Abstract n. 6/

26 CAICEDO, R. et al. Sealing capacity of super EBA ${ }^{\circledR}$, $\operatorname{ProRoot}^{\circledR}$ MTA, Diaket $^{\circledR}$, in the repair of root perforations. J Endod, v.26, n.9, p.553, Sept. 2000. /Abstract n. PR2/

27 CAMARGO, W.R. Interação dos cimentos Sealapex e CRCS com os macrófagos: estudo morfológico dos efeitos citotóxicos. Bauru, 1993. 96p. Dissertação (Mestrado) Faculdade de Odontologia de Bauru, Universidade de São Paulo.

28 CAMPOS QUINTANA, I.; LLAMOSAS HERNÁNDEZ, E.; MORALES DE LA LUZ, R. Evaluación de la biocompatibilidad del cemento Portland implantado en tejido conectivo subepitelial de ratas. Rev Assoc Dent Mex, v.40, n.2, p.45-51, mar./abr. 2003.

29 CATHERS, S.J.; KAMINSKI, E.J.; OSETEK, E.M. The cellular response to hydron within the rat peritoneal cavity. J Endod, v.10, n.5, p. 17381, May 1984.

30 CHAKMAKCHI, M. et al. Sealing effectiveness of white ProRoot MTA in furcation perforations. Int Endod J, v.36, n.12, p.945, Dec. 2003. /Abstract n. R75/ 
31 CONSEJO CANADIENSE DE PROTECCIÓN DE LOS ANIMALES DE EXPERIMENTACIÓN. La anestesia. In: . Manual sobre el cuidado y uso de los animales de experimentación. 2.ed. Canadá, 1998. v.1, cap.11, p.1-20.

32 CONSOLARO, A.; RIBEIRO, F.C. Periapicopatias: etiopatogenia e interrelações dos aspectos clínicos, radiográficos e microscópicos e suas implicações terapêuticas. In: LEONARDO, M.R.; LEAL, J.M. Endodontia: Tratamento de canais radiculares. 3.ed. São Paulo, Panamericana, 1998. Cap. 5, p. 77-102.

33 CONTRAN, R.S.; KUMAR, V.; ROBBINS, S.L. Patologia estrutural e funcional: inflamação e reparo. 4.ed. Rio de Janeiro, Guanabara Koogan, 1991. Cap. 2, p. 34-72.

34 COSTA, C.A.S. Testes de citotoxicidade em cultura de células. In: ESTRELA, C. Metodologia científica: ensino e pesquisa em odontologia. São Paulo, Artes Médicas, 2001. Cap. 9, p.147-60.

35 COSTA, C.A.S. Testes de biocompatibilidade dos materiais odontológicos. In: ESTRELA, C. Metodologia científica: ensino e pesquisa em odontologia. São Paulo, Artes Médicas, 2001. Cap. 10, p.163-94.

36 CUMMINGS, G.R.; TORABINEJAD, M. Mineral trioxide aggregate (MTA) as an isolating barrier for internal bleaching. J Endod, v.21, n.4, p.228, Apr. 1995. /Abstract n. RS53/

37 DEAL, B.F. et al. Chemical and physical properties of MTA, Portland cement, and a new experimental material, Fast-Set MTA. J Endod, v.28, n.3, p.252, Mar. 2002. IAbstract n. 70/ 
38 DEUS, G. et al. Citotoxicidade do Pro-Root MTA $®$, do MTA Angelus $®$ e do cimento Portland sobre culturas de células endoteliais - ECV. Braz Oral Res, v.17, p.116, Aug. 2003. Supplement 2. /Abstract n. Pa069/

39 DIAMANTI, E. et al. Chemical composition and surface characteristics of grey and new white ProRoot MTA. Int Endod J, v.36, n.12, p. 946-7, Dec. 2003. /Abstract n. R81/

40 DIXON, C.M.; RICKERT, U.G. Tissue tolerance to foreign materials. Arch Oral Biol, v.20, n.8, p.1458-72, Aug. 1933.

41 DUARTE, M.A.H. et al. Avaliação da contaminação do MTA Angelus e do cimento de Portland. J Bras Clin Odontol Int, v.6, n.32, p.155-7, mar./abr. 2002.

42 DUARTE, M.A.H. et al. $\mathrm{pH}$ and calcium ion release of 2 root-end filling materials. Oral Surg Oral Med Oral Pathol, v.95, n.3, p.345-7, Mar. 2003.

43 DUMSHA, T.C.; HOLT, G.M. Biocompatibility of bone cement, ProRoot, and Super-EBA in ferret canines. J Endod, v.26, n.9, p.554, Sept. 2000. /Abstract n. 8/

44 ECONOMIDES, N. et al. Experimental study of the biocompatibility of four root canal sealers and their influence on the zinc and calcium content of several tissues. J Endod, v.21, n.3, p.122-7, Mar. 1995.

45 ECONOMIDES, N. et al. Short-term periradicular tissue response to mineral trioxide aggregate (MTA) as root-end filling material. Int Endod J, v.36, n.1, p.44-8, Jan. 2003. 
46 EIDELMAN, E. et al. Mineral trioxide aggregate vs. Formocresol in pulpotomized primary molars: a preliminary report. Pediatr Dent, v.23, n.1, p.15-8, Jan./Feb. 2001.

47 ESPINDOLA, V.P. et al. Análise da qualidade do selamento em perfurações de furca: um estudo através de um modelo bacteriano. Braz Oral Res, v.17, p.58, Aug. 2003. Supplement 2. IAbstract n. Ib019/

48 ESTRELA, C. et al. Antimicrobial and chemical study of MTA, Portland cement, calcium hydroxide paste, Sealapex and Dycal. Braz Dent J, v.11, n.1, p.3-9, 2000.

49 FARACO JÚNIOR, I.M. Avaliação histomorfológica da resposta da polpa de dentes de cães submetida ao capeamento com sistema adesivo, cimento de hidróxido de cálcio e dois tipos de agregado de trióxido mineral. Araçatuba, 1999. 251p. Tese (Doutorado) Faculdade de Odontologia de Araçatuba, Universidade Estadual Paulista "Júlio de Mesquita Filho".

50 FARACO JÚNIOR, I.M.; HOLLAND, R. Response of the pulp of dogs to capping with mineral trioxide aggregate or a calcium hydroxide cement. Dent Traumatol, v.17, n.4, p.163-6, 2001.

51 FERRAZ, S.L. et al. Estudo da histocompatibilidade de cimento endodôntico no tecido conjuntivo subcutâneo utilizando três metodologias. Rev Odontol USP, v.4, n.3, p.241-6, jul./set. 1990.

52 FERRIS, D.M.; BAUMGARTNER, J.C. Perforation repair comparing two types of mineral trioxide aggregate. J Endod, v.30, n.6, p.422-4, June 2004. 
53 FISCHER, E.J. et al. Bacterial leakage of mineral trioxide aggregate as compared with zinc-free amalgam, intermediate restorative material, and super-EBA as a root-end filling material. J Endod, v.24, n.3, p.176-9, Mar. 1998.

54 FOGEL, H.M.; PEIKOFF, M.D. Microleakage of root-end filling materials. J Endod, v.27, n.7, p.456-8, July 2001.

55 FRANCO, K.P.B. Estudo histológico comparativo entre o MTA e o cimento Portland. Feira de Santana, 2001. 57p. Monografia (Especialização) - Faculdade de Odontologia, Universidade Estadual de Feira de Santana apud BERNABE, P.F.E.; HOLLAND, R. Cirurgia paraendodôntica: como practicá-la com embasamento científico. In: ESTRELA, C. Ciência endodôntica. São Paulo, Artes médicas, 2004. Cap.16, p.657-797.

56 FRIDLAND, M.; ROSADO, R. Mineral trioxide aggregate (MTA) solubility and porosity with different water-to-powder ratios. J Endod, v.29, n.12, p.814-7. Dec. 2003.

57 FRIEND, L.A.; BROWNE, R.M. Tissue reactions to some root filling materials. Br Dent J, v.125, n.7, p. 291-8, Oct. 1968.

58 FUNTEAS, U.R.; WALLACE, J.A.; FOCHTMAN, F.W. A comparative analysis of mineral trioxide aggregate and Portland cement. J Endod, v.28, n.3, p.259, Mar. 2002. /Abstract n. 21/

59 GARTNER, A.H.; DORN, S.O. Advances in endodontic surgery. Dent Clin North Am, v.38, n.2, p.357-78, Apr. 1992. 
60 GORDUYSUS, M.O.; ETIKAN, I.; GOKOZ, A. Histopathological evaluation of the tissue reactions to Endo-Fill canal sealant and filling materials material in rats. J Endod, v.24, n.3, p.194-6, Mar. 1998.

61 GUARIENTI, D.; OSINAGA, P.W.R.; FIGUEIREDO, J.A.P. Avaliação química e estrutural comparativa entre o cimento Portland e o MTA. Braz Oral Res, v.16, p.190, 2002. Supplement. /Abstract n. Pb167/

62 HAGLUND, R. et al. Effects of root-end filling materials on fibroblasts and macrophages in vitro. Oral Surg Oral Med Oral Pathol, v.95, n.6, p.739-45, June 2003.

63 HARDY, I. et al. Sealing ability of one-up bond and MTA with and without a secondary seal as furcation perforation repair materials. J Endod, v.30, n.9, p.658-61. Sept. 2004.

64 HAYASHI, M.; SHIMIZU, A.; EBISU, S. MTA for obturation of mandibular central incisors with open apices: case report. J Endod, v.30, n.2, p.120-2, Feb. 2004.

65 HEDRICH, H.J. History, strains and models. In: KRINKE, G.L. The Laboratory rat. London, Academic Press, 2000. Cap. 1, p.3-16.

66 HOLLAND, R. Histochemical response of amputed pulps to calcium hydroxide. Rev Bras Pesq Med Biol, v.4, n.2, p.83-95, 1971.

67 HOLLAND, R. et al. Estudo histológico do comportamento do tecido conjuntivo subcutâneo do rato ao implante de alguns materiais obturadores de canal radicular: influência da proporção pó-líquido. Rev Ass Paul Cir Dent, v.25, n.3, p.101-10, maio/jun. 1971. 
68 HOLLAND, R. et al. Resposta do tecido conjuntivo subcutâneo do rato ao implante de alguns materiais obturadores de canal. Ver Fac Odontol Araçatuba, v.2, n.2, p.217-25, 1973.

69 HOLLAND, R. et al. Resposta tecidual à implantação de diferentes marcas de cones de guta-percha. Estudo histológico em ratos. Rev Fac Odontol Araçatuba, v.4, n.1, p.81-90, Jan. 1975.

70 HOLLAND, R. et al. Reaction of dog's teeth to root canal filling with mineral trioxide aggregate or a glass ionomer sealer. J Endod, v.25, n.11, p.728-30, Nov. 1999.

71 HOLLAND, R. et al. Reaction of rat connective tissue to implanted dentin tubes filled with mineral trioxide aggregate or calcium hydroxide. J Endod, v.25, n.3, Mar. 1999.

72 HOLLAND, R. Et al. Agregado de trióxido mineral y cemento Portland en la obturación de conductos radiculares de perro. Endodoncia, v.19, n.4, p.275-80, oct./dic. 2001.

73 HOLLAND, R. et al. Healing process of dog dental pulp after pulpotomy and pulp covering with mineral trioxide aggregate or Portland cement. Braz Dent J, v.12, n.2, p.109-13, 2001.

74 HOLLAND, R. et al. Mineral trioxide aggregate repair of lateral root perforations. J Endod, v.27, n.4, p.281-4, Apr. 2001.

75 HOLLAND, R. et al. Reaction of rat tissue to implanted dentin tube filled with mineral trioxide aggregate, Portland cement or calcium hydroxide. Braz Dent J, v.12, n.1, p.3-8, 2001. 
76 HOLLAND, R. et al. Agregado de trióxido mineral (MTA): Composição, mecanismo de ação, comportamento biológico e emprego clínico. Ver Ciênc Odontol, v.5, n.5, p.7-21, 2002.

77 HOLLAND, R. et al. Calcium salts deposition in rat connective tissue after the implantation of calcium hydroxide - containing sealers. J Endod, v.28, n.3, p.173-6, Mar. 2002.

78 HOLLAND, R. et al. Reaction of rat connective tissue to implanted dentin tubes filled with a white mineral trioxide aggregate. Braz Dent J, v.13, n.1, p.23-6, 2002.

79 HONG, C.U. et al. Healing of furcal lesions repaired by amalgam or mineral trioxide aggregate. J Endod, v.20, n.4, p.197, Apr. 1994. /Abstract n. 37/

80 HUNTER, H.A. The effect of gutta-percha, silver points, and Rickert's root sealer on bone healing. J Canad Dent Ass, v.23, n.6, p.385-8, June 1957.

$81 \mathrm{HSIEN}, \mathrm{H}$. et al. Repair of perforating internal resorption with mineral trioxide aggregate: a case report. J Endod, v.29, n.8, p.538-9, Aug. 2003. 7405: dentistry - preclinical evaluation of biocompatibility of medical devices used in dentistry - test methods for dental materials. Genève, ISO, 1997.

83 JUNN, D.J. et al. Quantitative assessment of dentin bridge formation following pulp capping with mineral trioxide aggregate (MTA). J Endod, v.24, n.4, p.278, Apr. 1998. /Abstract n. 29/ 
84 KAPLAN, A.E. et al. Rheological properties and biocompatibility of endodontic sealers. Int Endod J, v.36, p.527-532, Aug. 2003.

85 KEISER, K.; JOHNSON, C.C.; TIPTON, D.A. Cytotoxicity of mineral trioxide aggregate using human periodontal ligament fibroblasts. J Endod, v.26, n.5, p.288-91, May 2000.

86 KETTERING, J.D.; TORABINEJAD, M. Investigation of mutagenicity of mineral trioxide aggregate and other commonly used root-end filling materials. J Endod, v.21, n.11, p.537-9, Nov. 1995.

$87 \mathrm{KOH}$, E.T. et al. Mineral trioxide aggregate stimulates a biological response in human osteoblasts. J Biomed Mat Res, v.37, n.3, p.4329, Dec. 1997.

$88 \mathrm{KOH}$, E.T. et al. Cellular response to mineral trioxide aggregate. J Endod, v.24, n.8, p.543-7, Aug. 1998.

89 KOLOKURIS, I. Et al. Experimental study of the biocompatibility of a new glass-ionomer root canal sealer (Ketac-Endo). J Endod, v.22, n.8, p.395-8, Aug. 1996.

90 KOLOKOURIS, I. Et al. In vivo comparison of the biocompatibility of two root canal sealers implanted into the subcutaneous connective tissue of rats. J Endod, v.24, n.2, p.82-5, Feb. 1998.

91 KRANZ, M.L. MTA-Angelus: Relatório técnico. Londrina, Soluções em Odontologia, 2004. (MT003).

92 KRONFELD, R.; BOYLE, P.E. Histopatologia dos dentes. 3 ed. Rio de Janeiro, Científica, 1955. p.262. 
93 LANDIS, J.R.; KOCH, G.G. The measurement of observer agreement for categorical data. Biometrics, v.33, n.1, p.159-74, Mar. 1977.

94 LANGELAD, K.; OLSSON, B.; PASCON, E.A. Biological evaluation of Hydron. J Endod, v.7, n.5, p.196-204, 1981.

95 LANGELAND, K. et al. Methods in the study of biologic responses to endodontic materials. Oral Surg, v.27, n.4, p.522-42, Apr. 1969.

96 LEE, S.J.; MONSEF, M.; TORABINEJAD, M. Sealing ability of a mineral trioxide aggregate for repair of lateral root perforations. J Endod, v.19, n.11, p.541-4, Nov. 1993.

97 LEONARDO, R.T. Avaliação microscópica da reação apical e periapical frente a dois cimentos obturadores de canais radiculares a base de hidróxido de cálcio (CRCS e Sealapex) em dentes de cães. Bauru, 1992. 104p. Dissertação (Mestrado) Faculdade de Odontologia de Bauru, Universidade de São Paulo.

98 LEONARDO, M.R. et al. A comparison of subcutaneous connective tissue responses among three different formulation of gutta-percha used in thermatic techniques. Int Endod J, v.23, n.4, p.211-7, 1990.

99 LOXLEY, E.C. et al. The effect of various intracanal oxidizing agents on the push-out strength of various perforation repair materials. Oral Surg Oral Med Oral Pathol, v.95, n.4, p.490-4, Apr. 2003.

100 MAIN, C. et al. Repair of root perforations using mineral trioxide aggregate: a long-term study. J Endod, v.30, n.2, p.80-83, Feb. 2004.

101 MAKKES, S.K. et al. Polyethylene tubes as a model for the root canal. Oral Surg, v.44, n.2, p.293-300, Aug. 1977. 
102 MAROTO, M. et al. Treatment of a non-vital immature incisor with mineral trioxide aggregate (MTA). Dent Traumatol, v.19, n.3, p.165-9, June 2003.

103 MARTELL, B.; CHANDLER, N.P. Electrical and dye leakage comparison of MTA, super EBA and IRM. J Endod, v.26, n.9, p.545, Sept. 2000. /Abstracts n.39/

104 MENEZES, R.S. da. Avaliação microscópica da resposta do complexo dentino-pulpar de dentes de cães ao agregado de trióxido mineral. Bauru, 2003. 90p. Dissertação (Mestrado) Faculdade de Odontologia de Bauru, Universidade de São Paulo.

105 MENEZES R.S. et al. Histologic evaluation of pulpotomies in dog using two types of mineral trioxide aggregate and regular and white Portland cement as wound dressings. Oral Surg Oral Med Oral Pathol, v.98, n.3, p.376-9, Sept. 2004.

106 MITCHELL, D.F. The irritational qualities of dental materials. J Amer Dent Assoc, v.59, p.954-66, Nov. 1959.

107 MITCHELL, P.J.C. et al. Osteoblast biocompatibility of mineral trioxide aggregate. Biomaterials, v.20, n.2, p.167-73, Jan. 1999.

108 MOLLOY, D. et al. Comparative tissue tolerance of a new endodontic sealer. Oral Surg Oral Med Oral Pathol, v.73, p.490-3, 1992.

109 MORAES, S.H.; ARAGÃO, E.M. de; HECK, A.R. Reação do tecido conjuntivo subcutâneo de rato ao implante do cimento Portland. J Bras Endod, v.2, n.7, p.326-329, out./dez. 2001. 
110 MORETTON, T.R. et al. Tissue reactions after subcutaneous and intraosseous implantation of mineral trioxide aggregate and ethoxybenzoic acid cement. J Biom Mat Res, v.52, n.3, p.528-33, Oct./Dec. 2000.

111 MOTTA, A.G. da et al. Reação do tecido conjuntivo subcutâneo de rato ao MTA e ao hidróxido de cálcio. Rev Bras Odontol, v.60, n.4, jul./ago. 2003.

112 MTA ANGELUS. Cimento reparador: indicações e técnica de uso. Londrina, Soluções em Odontologia. 2003.

113 MYERS, K. et al. The effects of mineral trioxide aggregate on the dog pulp. J Endod, v.22, n.4, p.198, Apr. 1996. /Abstract n. 39/

114 NAGEM FILHO, H. Reações histopatológicas do tecido conjuntivo subcutâneo do rato a implantes simples (ouro ou amálgama de prata) ou mistos (ouro e amálgama de prata). Bauru, 1972. Dissertação (Mestrado) Faculdade de Odontologia de Bauru, Universidade de São Paulo.

115 NAKATA, T.T.; BAE, K.S.; BAUMGARTNER, J.C. Perforation repair comparing mineral trioxide aggregate and amalgam using an anaerobic bacterial leakage model. J Endod, v.24, n.3, p.184-6, Mar. 1998.

116 OLSSON, B.; SLIWKOWSKI, A.; LANGELAND, K. Subcutaneous implantation for the biological evaluation of endodontic materials. $\mathbf{J}$ Endod, v.7, n.8, p.355-69, Aug. 1981. 
117 ØRSTAVIK, D.; MJÖR, I.A. Histopathology and X-ray microanalysis of the subcutaneous tissue response to endodontic sealers. J Endod, v.14, n.1, p.13-23, Jan. 1988.

118 OSORIO, R.M. et al. Cytotoxicity of endodontic materials. J Endod, v.24, n.2, p.91-6, Feb. 1998.

119 PEREIRA, E.M. et al. Capacidade de vedamento de diversos materiais em perfurações radiculares. Rev Bras Odontol, v.60, n.5, p.349-52, set./out. 2003.

120 PÉRES, A.L. et al. Osteoblasts and MG-63 osteosarcoma cells behave differently when in contact with ProRootTM MTA and White MTA. Int Endod J, v.36, n.8, p.564-70, Aug. 2003.

121 PHILLIPS, J.M. Rat connective tissue response to hollow polyethylene tube implants. J Canad Dent Ass, v.33, n.2, p.59-64, 1967.

122 PITT FORD, T.R. et al. Use de mineral trioxide aggregate for repair of furcal perforations. Oral Surg Oral Med Oral Pathol Oral Radiol Endod, v.79, n.6, p.756-63, June 1995.

123 PITT FORD, T.R. et al. Using Mineral Trioxide Aggregate as a pulpcapping material. J Am Dent Assoc, v.127, n.10, p.1491-4, Oct. 1996.

124 PRO ROOT MTA (Mineral Trioxide Aggregate). Root canal repair material water: directions for use. Tulsa, Dentsply-Maillefer,Tulsa Dental, 2002.

125 POSHADLEY, A.G.; HARRISON, J.D. Rat connective tissue response to pontic materials. J Prosthet Dent, v.16, p.110-118, 1966. 
126 REGAN, J.D.; GUTMANN, J.L.; WITHERSPOON, D.E. Comparision of Diaket and MTA when used as root-end filling materials to support regeneration of the periradicular tissues. Int Endod J, v.35, n.10, p.840-7, Oct. 2002.

127 RODRIGUEZ SOSA, S. A. Reação histopatológica do tecido conjuntivo do dorso de ratos irradiado com laser de $\mathrm{CO}_{2}$ ou de Er:YAG. Araraquara, 2004. 98p. Dissertação (Mestrado) Faculdade de Odontologia, Universidade Estadual Paulista.

128 ROY, C.O. et al. Effect of an acid environment on leakage of root-end filling materials. J Endod, v.27, n.1, p.7-8, Jan. 2001.

129 SAFAVI, K.; NICHOLS, F.C. Secretion of PGE 2 from monocytes exposed to MTA or Portland cement. J Endod, v.26, n.9, p.540, Sept. 2000. /Abstract n. 18/

130 SAFAVI, K.E.; PASCON, E.A.; LANGELAND, K. Evaluation of tissue reaction to endodontic materials. J Endod, v.9, n.10, p.421-29, Oct. 1983.

131 SAIDON, J. et al. Tissue reaction to implanted mineral trioxide aggregate or Portland cement. J Endod, v.28, n.3, p.247, Mar. 2002. /Abstract n. 521

132 SAIDON, J. et al. Cell and tissue reactions to mineral trioxide aggregate and Portland cement. Oral Surg Oral Med Oral Pathol, v.95, n.4, p.483-9, Apr. 2003. 
133 SAMPAIO, J.M.P. Estudo do processo cicatricial, após implante do tecido conjuntivo de ratos, de tubos de polietileno contendo cimentos obturadores de condutos radiculares em sua fórmulas originais e acrescidos de delta hidrocortisona. Rev Fac Odont São Paulo, v.12, n.1, p.75-83, jan./jul. 1974.

134 SAMPAIO, J.M. Obturação. In: PAIVA, J.G.; ALVARES, S. Endodontia. São Paulo, Atheneu, 1979. p.300-13.

135 SCHWARTZ, R.S. et al. Mineral trioxide aggregate: a new material for endodontics. J Am Dent Assoc, v.130, n.7, p.967-75, July 1999.

136 SEUX, D. et al. Odontoblast-like cytodifferentiation of human dental pulp cells in vitro in the presence of a calcium hydroxide containing cement. Arch Oral Biol, v.36, n.2, p.117-28, Jan./June 1991.

137 SHABAHANG, S. et al. A comparative Study of root-end induction using osteogenic protein-1, calcium hydroxide, and mineral trioxide aggregate in dogs. J Endod, v.25, n.1, p.1-5, Jan. 1999.

138 SHIN, S. et al. Biocompatibility and mitogenic effect of several root-end filling materials in osteoblast and odontoblast cultures. J Endod, v.29, n.4, p.306, Apr. 2003. /Abstract n. 29/

139 SILVA, R.F. et al. Estudo das propriedades de estabilidade dimensional e solubilidade e desintegração dos cimentos mta e tipo portland. Braz Oral Res, v.16, p.145, 2002. Supplement. IAbstract n. Pa186/ 
140 SILVA HERZOG-FLORES, D. et al. Análisis fisicoquímico del mineral trióxido agregado (MTA) por difracción de rayos $X$ calorimetría y microscopia electrónica de barrido. Rev Assoc Dent Mex, v.57, n.4, p.125-31, jul./ago. 2000.

141 SLUYK, S.R.; MOON, P.C.; HARTWELL, G.R. Evaluation of setting properties and retention characteristics of mineral trioxide aggregate when used as a furcation perforation repair material. J Endod, v.24, n.11, p.768-71, Nov. 1998.

142 SMITH, J.W; LEEB, I.J.; TORNEY, D.L. A comparison of calcium hydroxide and barium hydroxide as agents for inducing apical closure. J Endod, v.10, n.2, p.64-70, Feb. 1984.

143 SNIDER, D. et al. Effect of root canal obturation and/or coronal seal on the success of root canal therapy. J Endod, v.25, n.4, p.294, Apr. 1999. /Abstract n. OR50/

144 SOARES, I.M.L. Resposta pulpar ao MTA - Agregado de Trióxido Mineral - comparada ao hidróxido de cálcio, em pulpotomias. Histológico em cães. Florianópolis, 1996. 74p. Concurso (Professor Titular) - Centro de Ciências da Saúde, Universidade Federal de Santa Catarina.

145 SPANGBERG, L. Biologic effects of root filling materials. Experimental investigation of the toxicity of root canal filling materials "in vitro" and "in vivo". Odont Revy, v.20, p.5-32, 1969.

146 SPANGBERG, L.; LANGELAND, K. Biologic effects of dental materials. 1. Toxicity of root canal filling materials on HeLa cells in vitro. Oral Surg, v.35, n.3, p.402-14, 1973. 
147 STANLEY, H.R. Toxicity testing of dental materials. Florida, CRC Press, 1985.

148 STANLEY, H.R. Biological evaluation of dental material. Int Dent J, v.42, n.1, Feb. 1992.

149 STANFORD, J.W. Recommended standard practices for biological evaluation of dental materials. Int Endod J, v.30, n.2, p.140-88, June 1980.

150 SUBRAMANIAN, K. et al. Can ProRoot ${ }^{\circledR}$ become more microbe "unfriendly". J Endod, v.29, n.4, p.306, Apr. 2003. /Abstract n. 31/

151 TANG, H.M.; TORABINEJAD, M.; KETTERING, J.D. Leakage evaluation of root end filling materials using endotoxin. J Endod, v.28, n.1, p.5-7, Jan. 2002.

152 THOMSON, T.S. et al. Osteocalcin expression by cementoblasts attached to mineral trioxide aggregate. J Endod, v.27, n.3, Mar. 2001. /Abstract n. 42/

153 THOMSON, T.S. et al. Cementoblasts maintain expression of osteocalcin in the presence of mineral trioxide aggregate. J Endod, v.29, n.6, p.407-12, June 2003.

154 TITTLE, K. et al. Apical closure induction using bone growth factors and mineral trioxide aggregate. J Endod, v.22, n.4, p.198, 1996. /Abstracts/

155 TORABINEJAD, M.; CHIVIAN, N. Clinical applications of mineral trioxide aggregate. J Endod, v.25, n.3, p.197-205, Mar. 1999. 
156 TORABINEJAD, M.; PITT FORD, T.R. Root end filling materials: a review. J Endod, v.12, n.4, p.161-78, Aug. 1996.

157 TORABINEJAD, M.; WATSON, T.F.; PITT FORD, T.R. Sealing ability of a mineral trioxide aggregate when used as a root end filling material. $\mathbf{J}$ Endod, v.19, n.12, p.591-5, Dec. 1993.

158 TORABINEJAD, M. et al. Dye leakage of four root end filling materials: effects of blood contamination. J Endod, v.20, n.4, p.159-63, Apr. 1994.

159 TORABINEJAD, $M$. et al. Bacterial leakage of a mineral trioxide aggregate as a root-end filling material. J Endod, v.21, n.3, p.109-12, Mar. 1995.

160 TORABINEJAD, M. et al. Citotoxicity of four root end filling materials. J Endod, v.21, n.10, p.489-92, Oct. 1995.

161 TORABINEJAD, $M$. et al. Comparative investigation of marginal adaptation of mineral trioxide aggregate and other commonly used root-end filling materials. J Endod, v.21, n.6, p.295-9, June 1995.

162 TORABINEJAD, M. et al. Investigation of mineral trioxide aggregate for root-end filling in dogs. J Endod, v.21, n.12, p.603-8, Dec. 1995.

163 TORABINEJAD, M. et al. Physical and chemical properties of a new rootend filling material. J Endod, v.21, n.7, p.349-53, July 1995.

164 TORABINEJAD, M. et al. Tissue reaction to implanted Super-EBA and mineral trioxide aggregate in the mandible of guinea pigs: a preliminary report. J Endod, v.21, n.11, p.569-71, Nov. 1995. 
165 TORABINEJAD, M. et al. Histologic assessment of mineral trioxide aggregate as a root-end filling in monkeys. J Endod, v.23, n.4, p.2258, Apr. 1997.

166 TORABINEJAD, M. et al. Tissue reaction to implanted root-end filling materials in the tibia and mandible of guinea pigs. J Endod, v.24, n.7, p.468-71, July 1998.

167 TORNECK, C.D. Reaction of rat connective tissue to polyethylene tube implants. Oral Surg, v.21, n.3, p.379-87, Mar. 1966.

168 TORNECK, C.D. Reaction of rat connective tissue to polyethylene tube implants. Oral Surg, v.24, n.5, p.674-83, Nov. 1967.

169 TRINDADE, A.C.; FIGUEIREDO, J.A.P. Análise química e estrutural do mta e do cimento de Portland, isolado e acrecido de substâncias radiopatizantes. Braz Oral Res, v.16, p.129, 2002. Supplement. /Abstract n. Pa054/

170 TRINDADE, A.C.; OLIVEIRA, E.P.M. de.; FIGUEIREDO, J.A.P. de. Análise comparativa da resposta tecidual ao agregado trióxido mineral (MTA) e ao cimento Portland, isolado e acrescido de substância radiopatizante. J Bras Endod, v.4, n.15, p.309-14, out./dez. 2003.

171 TROWBRIDGE, H.O.; EMLING, R.C. Inflammation: a review of the process. 5.ed. Chicago, Quintessence Books, 1997.

172 TZIAFAS, D. et al. The dentinogenic effect of mineral trioxide aggregate (MTA) in short-term capping experiments. Int Endod J, v.35, n.3, p.245-54, Mar. 2002. 
173 VALERA, M.C. Estudo da compatibilidade biológica de alguns cimentos endodônticos à base de hidróxido de cálcio e um cimento de ionômero de vidro. Avaliação do selamento marginal apical e análise morfológica por microscopia de força atômica. Araraquara, 1995. 332 p. Tese (Doutorado) Faculdade de Odontologia, Universidade Estadual Paulista.

174 VIZGIRDA, P.J. et al. A comparison of laterally condensed gutta-percha, thermoplasticized gutta-percha and mineral trioxide aggregate as root canal filling materials. J Endod, v.28, n.3, p.246, Mar. 2002. /Abstract n. OR46/

175 WELDON, J.K. et al. Sealing ability of mineral trioxide aggregate and Super-EBA when used as furcation repair materials: a longitudinal study. J Endod, v.28, n.6, p.467-70, June 2002.

176 WESTPHALEN, F.H. et al. Análise comparativa da radiopacidade de cimentos Portland e MTA. Braz Oral Res, v.17, p.182, Aug. 2003. Supplement 2. IAbstract n. Pb192/

177 WILLERSHAUSEN, B. et al. Biocompatibility of orthograde and retrograde root canal filling materials. J Endod, v.26, n.9, p.545, Sept. 2000. /Abstract n. 38/

178 WOLFSON, E.M.; SELTZER, S. Reaction of rat connective tissue to some gutta-percha formulations. J Endod, v.1, n.12, p.395-402, Dec. 1975.

179 WU, M.K. et al. Long-term seal provided by some root-end filling materials. J Endod, v.24, n.8, p.557-60, Aug. 1998. 
180 WUChERPFENNIG, A.L.; GREEN, D.B. Mineral trioxide vs. Portland cement: two biocompatible filling materials. J Endod, v.25, n.4, p.308, April 1999. IAbstract n. 40/

181 XAVIER, M.J. et al. Comportamento histopatológico do tecido conjuntivo de rattus norvegicus var. albinus a implantes dos cimentos para obturação de canais: Rickert, AH-26 e Endométhasone. Estomat e Cultura, v.8, n.1, p.61-71, jan./jun. 1974.

182 YALTIRIK, M. et al. Reaction of connective tissue to mineral trioxide aggregate and amalgam. J Endod, v.30, n.2, p.95-9, Feb. 2004.

183 ZANONI, E.M.S. et al. Espaços vazios nas obturações endodônticas. RGO, v.36, n.3, p.232-9, maio/jun. 1988.

$184 \mathrm{ZHU}, \mathrm{Q}$. et al. Adhesion of human osteoblasts on root-end filling materials. J Endod, v.26, n.7, p.404-6, July 2000.

185 ZMENER, O. Tissue response to a new methacrylate-based root canal sealer: Preliminary observations in the subcutaneous connective tissue of rats. J Endod, v.30, n.5, p.348-351, May 2004.

186 ZMENER, O.; GUGLIELMOTTI, M.B.; CABRINI, R.L. Biocompatibility of two calcium hydroxide-based endodontic sealers: a quantitative study in the subcutaneous connective tissue of the rat. $\mathbf{J}$ Endod, v.14, n.5, p.229-35, May 1988.

187 ZMENER, O.; GUGLIELMOTTI, M.B.; CABRINI, R.L. Tissue response to an experimental calcium hydroxide-based endodontic sealer: a quantitative study in subcutaneous connective tissue of the rat. Endod Dent Traumatol, v.6, n.2, p.66-72, Apr. 1990. 
ABSTRACT 


\begin{abstract}
Evaluation of the reaction of subcutaneous tissue of rats to implantation of white MTA and white Portland cement with radiopacifiers
\end{abstract}

Because of its good physicochemical and biological properties, MTA is indicated as a material for retrograde obturations. The aim of this study was to microscopically evaluate the response of the subcutaneous tissue of rats to the implantation of polyethylene tubes containing new formulations of this material: ProRoot $M_{T}{ }^{\circledR}$, White $M_{T A}{ }^{\circledR}$ containing two types of radiopacifiers, and white Portland cement with bismuth oxide. Thirtysix rats (Rattus norvegicus) were employed, which were divided into 12 animals for each study period. Each animal received 4 implants of polyethylene tubes filled with the recently prepared materials at one side, and gutta-percha at the other side (control). After 15, 30 and 60 days, the animals were killed and the specimens were prepared for microscopic analysis. The results demonstrated granulomatous chronic inflammation induced by the materials, of moderate to mild intensity, and organization and thickening of a fibrous capsule with time. The cements induced similar tissue responses, despite the presence of different radiopacifiers in their composition. 
APÊNDICE 


\title{
Universidade de São Paulo Faculdade de Odontologia de Bauru
}

Al. Dr. Octávio Pinheiro Brisolla, 9-75 - Bauru-SP - CEP 17012-901 - C.P. 73 PABX (0XX14)235-8000 - FAX (0XX14)223-4679

\author{
Comissão de Élica no Ensino e Pesquisa em Animais
}

\section{CEEPA-Proc. $N^{o} 35 / 2003$}

Bauru, 07 de novembro de 2003

Senhor Professor,

O projeto de pesquisa encaminhado a esta Comissão de Ética no Ensino e Pesquisa em Animais, denominado "Avaliação da biocompatibilidade do ProRoot White, MTA-Ângelus branco associado a dois tipos de radiopacificadores e cimento Portland branco quando implantados no tecido subcutâneo de ratos", de autoria de Eduardo Antunes Bortoluzzi, a ser desenvolvido sob sua orientação, foi enviado ao relator para avaliação.

Na reunião de 05 de novembro de 2003 esta Comissão aprovou o parecer do relator, considerando que não existem infrações éticas, com as seguintes considerações:

"A eleição da espécie animal para a pesquisa em apreço foi adequada, pelo fato do rato constituir um modelo biológico apropriado para o tipo de experimentação a ser utilizada. Também é adequado o manejo, os procedimentos cirúrgicos, a anestesia e o sacrificio dos animais para a coleta do material a ser estudado. Quanto ao número de animais a serem empregados, um tanto quanto exagerado (10 por grupo), justifica-se, em termos de amostragem, para os cálculos necessários ao tratamento estatístico (não explicitado no protocolo de pesquisa)".

Atenciosamente,

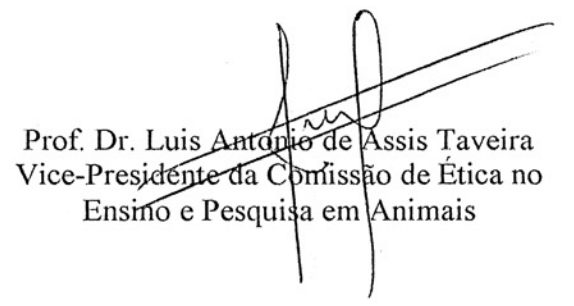

$\mathrm{Ilm}^{\circ} \mathrm{Sr}$. Prof. Dr. Clovis Monteiro Bramante

DD. Docente do Departamento de Dentística, Endodontia e Materiais Dentários 